\title{
Traços épico-brechtianos na dramaturgia portuguesa
}

o render dos heróis, de Cardoso Pires, e Felizmente há luar!, de Sttau Monteiro

\author{
Márcia Regina Rodrigues
}

RODRIGUES, MR. Traços épico-brechtianos na dramaturgia portuguesa: o render dos heróis, de Cardoso Pires, e Felizmente há luar!,de Sttau Monteiro [online]. São Paulo: Editora UNESP; São Paulo: Cultura Acadêmica, 2010. 147 p. ISBN 978-85-7983-114-0. Available from SciELO Books <http://books.scielo.org>.

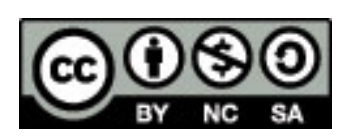

All the contents of this work, except where otherwise noted, is licensed under a Creative Commons Attribution-Non Commercial-ShareAlike 3.0 Unported.

Todo o conteúdo deste trabalho, exceto quando houver ressalva, é publicado sob a licença Creative Commons Atribuição Uso Não Comercial - Partilha nos Mesmos Termos 3.0 Não adaptada.

Todo el contenido de esta obra, excepto donde se indique lo contrario, está bajo licencia de la licencia Creative Commons Reconocimento-NoComercial-CompartirIgual 3.0 Unported. 


\section{Traços ÉPICO-BRECHTIANOS NA DRAMATURGIA PORTUGUESA}


CONSELHO EDITORIAL ACADÊMICO

Responsável pela publicação desta obra

Alcides Cardoso dos Santos

João Batista Toledo Prado

Márcia Valéria Zamboni Gobbi 


\section{MÁRCIA REGINA RODRIGUES}

\section{TraÇOS \\ ÉPICO-BRECHTIANOS \\ NA DRAMATURGIA PORTUGUESA \\ O RENDER DOS HERÓIS, de Cardoso Pires, \\ e FELIZMENTE HÁ LUAR!, de Sttau Monteiro}

CULTURA

$\frac{\text { ACADÊMICA }}{\mathcal{E} \text { diton } a}$ 


\section{(C) 2010 Editora UNESP}

\section{Cultura Acadêmica}

Praça da Sé, 108

01001-900 - São Paulo - SP

Tel.: (0xx11) 3242-7171

Fax: (0xx11) 3242-7172

www.editoraunesp.com.br

feu@editora.unesp.br

CIP - Brasil. Catalogação na fonte

Sindicato Nacional dos Editores de Livros, RJ

R614t

Rodrigues, Márcia Regina

Traços épico-brechtianos na dramaturgia portuguesa : 0 render dos heróis, de Cardoso Pires, e Felizmente há luar!, de Sttau Monteiro / Márcia Regina Rodrigues. - São Paulo : Cultura Acadêmica, 2010.

Inclui bibliografia

ISBN 978-85-7983-114-0

1. Pires, José Cardoso, 1925-1998. O render dos heróis. 2. Monteiro, Luís de Sttau, 1926-1993. Felizmente há luar!. 3. Brecht, Bertolt, 1898-1956 - Influência. 4. Teatro português (Literatura) - História e crítica. 5. Teatro e sociedade - Portugal. I. Título. II. Título: O render dos heróis, de Cardoso Pires. III. Título: Felizmente há luar!, de Sttau Monteiro.

10-0097.

CDD: 869.2

CDU: 821.134.3-2

Este livro é publicado pelo Programa de Publicações Digitais da Pró- Reitoria de Pós-Graduação da Universidade Estadual Paulista "Júlio de Mesquita Filho" (UNESP)

Editora afiliada:

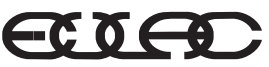

Asociación de Editoriales Universitarias de América Latina y el Caribe

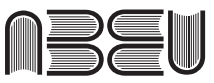

Associação Brasileira de Editoras Universitárias 
Agradeço à professora Renata Soares Junqueira pela dedicada leitura crítica que fez de meus textos e pela orientação do caminho; a Arthur Autran pelas palavras de estímulo; aos professores Litian Lopondo, José Pedro Antunes e Márcia Valéria Zamboni Gobbi; à Coordenação de Aperfeiçoamento de Pessoal de Nivel Superior (Capes) pela bolsa concedida para a viabilização de minha pesquisa. 
O homem não é regido por forças insondáveis que para sempre lhe determinam a situação metafísica. Depende, ao contrário, da situação histórica que, por sua vez, pode ser transformada.

(Anatol Rosenfeld 2006, p.150) 


\section{SuMÁrio}

Introdução 11

1 A situação do teatro português na década de $1960 \quad 17$

2 Algumas considerações sobre o teatro épico de Brecht 43

3 O render dos heróis, a fábula histórica de Cardoso Pires 79

4 Felizmente há luar!, a fábula histórica de Sttau Monteiro 105

Considerações finais 129

Referências bibliográficas 141

Bibliografia complementar 145 


\section{INTRODUÇÃO}

Mais do que no romance, e ainda mais que na poesia, o teatro adere à realidade imediata, que frequentemente o submerge. Isso explica, por um lado, a proliferação das obras de teatro, e por outro o número relativamente diminuto das que logram transcender esse circunstancialismo que lhes está na origem e cuja aceitação é, no entanto, uma condição sine qua non

da sua própria existência teatral. (Rebello, 1984, p.10)

Depois da Segunda Guerra, o teatro português abre um novo capítulo em sua história com a criação de várias companhias, com o surgimento de novos dramaturgos e com a busca de uma estética teatral que respondesse aos anseios eàs inquietações dos artistas frente à realidade. Até a Revolução dos Cravos (25 de abril de 1974), entretanto, vamos observar um fenômeno recorrente: muitas peças foram escritas e pouquíssimas delas foram encenadas. Impedidas de subirem 
à cena pela censura instituída pelo governo ditatorial de António de Oliveira Salazar, ${ }^{1}$ um número considerável de obras teatrais chegou a público apenas em forma de livro. O teatro em Portugal era mais lido que encenado. Um "divórcio”, como bem definiu Luiz Francisco Rebello (1972), acentuava-se entre dramaturgia e encenação. Devido a esse particular, o teatro português desse período, como analisa Fernando Mendonça (1971), preocupava-se principalmente com o texto, valorizando a palavra, o diálogo cheio de conteúdo, já que o dramaturgo, ao escrever, sabia que pouca chance teria de ver sua peça encenada.

No que tange à questão estética, vemos, na maior parte das peças, a rejeição das formas naturalistas e a valorização do anti-ilusionismo como características fundamentais e princípios que levaram os dramaturgos à elaboração, construção e utilização de recursos cênicos múltiplos, que, muitas vezes, acabavam por constituir um notável hibridismo na linguagem cênica (Mendonça, 1971).

É principalmente nas duas últimas décadas que antecedem a Revolução dos Cravos que o teatro integra a seus temas e formas uma preocupação em abrir o caminho para a reflexão crítica sobre a realidade, denunciando as injustiças sociais e preconizando um posicionamento conscientemente político do público. Nesse contexto, o teatro épico - desenvolvido, praticado e teorizado pelo dramaturgo alemão

1 Em 28 de maio de 1926 tem início a ditadura portuguesa, decorrente do golpe militar que pôs fim à Primeira República. António de Oliveira Salazar (1889-1970) é designado ministro das Finanças em 1928; em 1932, é nomeado chefe do Conselho de Ministros, oficializando o Estado Novo em 1933, quando promulga a legislação da censura e a criação do Secretariado de Propaganda Nacional. Por problemas de saúde, Salazar é afastado do poder em 1968, sendo nomeado Marcelo Caetano o seu sucessor. Salazar morre em 1970 sem saber que não governava mais o país. Depois de 48 anos de ditadura, a Revolução dos Cravos, em 25 de abril de 1974, põe fim ao regime, instaurando a democracia em Portugal. 
Bertolt Brecht (1889-1956)-, cujo principal objetivo é o de "possibilitar ao espectador uma crítica fecunda, dentro de uma perspectiva social” (Brecht, 2005, p.97), tornava-se uma "novidade [que] parecia dar resposta a algumas das perplexidades dos dramaturgos portugueses" (Barata, 1991, p.356). Assim, os dramaturgos e os demais artistas do teatro português começaram a entrar em contato com a dramaturgia e a teoria do teatro épico brechtiano, obtendo conhecimento dos pressupostos teóricos do dramaturgo alemão por meio das traduções francesas ou inglesas que circulavam em Portugal e de estadas na França, Inglaterra ou Alemanha, onde assistiam aos espetáculos. ${ }^{2}$

Em finais dos anos de 1950 e na década de 1960, a criação de novas companhias de teatro e o surgimento de novos dramaturgos foram fatores que contribuíram para aumentar a atividade teatral e também o interesse por Brecht, cuja obra dramática começava a ser traduzida para o português, ainda que de forma intermitente e dispersa. Mas as encenações de peças brechtianas - com uma ou outra exceção, como veremos - foram totalmente proibidas nos palcos portugueses pela comissão de censura do Estado Novo. Nesse período, o regime salazarista tornava-se ainda mais repressor, e "proibir o teatro, como instrumento de conscientização e promoção sociocultural, como meio de desalienação e desmistificação das mais vastas camadas populacionais, era efectivamente a aspiração secreta do regime" (Rebello, 1977, p.39).

É no teatro de 1960, caracterizado pela intensa produção dramatúrgica sob a mira da censura salazarista, que incide nosso estudo. Dessa dramaturgia publicada interessa-nos

2 O espetáculo $\mathrm{O}$ círculo de giz caucasiano, com direção do próprio Brecht, apresentado no Teatro Sarah Bernhardt, no II Festival de Arte Dramática de Paris, em 1955, foi marcante para os atores portugueses do Teatro Nacional que também participaram do festival (Dellile, 1991a). 
exclusivamente a de cariz brechtiano. Sendo assim, elegemos como objeto de análise duas peças consideradas pela crítica os primeiros frutos da perspectiva brechtiana de teatro épico na dramaturgia portuguesa: O render dos heróis (1960), de José Cardoso Pires (1925-1998), e Felizmente há luar! (1961), de Luís de Sttau Monteiro (1926-1993).

O render dos heróis - peça em "três partes e um epílogo concluído em apoteose grotesca", como a define seu autor - trata da revolta popular, ocorrida em 1846, denominada "Maria da Fonte", nome atribuído à mulher considerada a instigadora dos motins iniciais da revolta. Felizmente, há luar! - peça em dois atos - narra a trajetória do general Gomes Freire de Andrade, sentenciado à morte, em 1817 , pelos governadores do reino, por ter sido considerado o líder da Revolução Liberal. Tanto $O$ render dos heróis como Felizmente há luar! apresentam fatos históricos remanescentes ou antecedentes da Revolução Liberal de 1820, com o claro objetivo de levar o espectador a uma análise crítica da situação político-social do Portugal da década de 1960. Da mesma forma, a escolha estética dos dramaturgos vincula-se à preocupação de criar artisticamente formas de crítica e de resistência ao regime político vigente no país.

A peça de Cardoso Pires foi encenada pela primeira vez em 1965, mas logo sofreu os processos da censura, ficando pouco tempo em cartaz em Lisboa. Felizmente há luar! não foi autorizada a ser representada, tendo sido encenada em Paris, em 1969, e em Portugal somente em 1978, depois da Revolução dos Cravos. Foram, portanto, obras dramáticas que estabeleceram a comunicação com o público primeiramente, e durante um bom tempo, mais por meio da leitura. Por isso é possível afirmar que essas duas peças, pelo menos até 1974 , foram mais lidas que encenadas. Daí seu público ser, à época, predominantemente constituído por leitores e não por espectadores. 
Para pensar o teatro português do referido período e analisar essas duas peças, consideramos os modos de aplicação da censura (aos textos e aos espetáculos), praticados pela ditadura de Oliveira Salazar e de seu sucessor, Marcelo Caetano, e o teatro épico brechtiano como escolha estética dos dramaturgos que o adotaram como uma possibilidade de proporcionar ao espectador a oportunidade de reflexão sobre seu tempo. Primeiro apresentamos uma breve descrição da situação do teatro português na década de 1960, enfatizando a tensa relação da arte dramática com a censura. Em seguida, algumas considerações acerca do teatro épico de Brecht, já que é para essa estética que se volta o interesse de parte dos dramaturgos portugueses desse período. Da obra teórica de Brecht salientamos o elemento caracterizador do teatro épico brechtiano, o efeito de distanciamento, a partir de dois aspectos: a encenação épica e os modos de teatralização - isto é, de o teatro mostrar-se teatro. O primeiro aspecto refere-se mais especificamente às recomendações de Brecht sobre as técnicas utilizadas para a atuação do ator; o segundo, aos recursos empregados para a constituição da cena dita épica.

O principal objetivo deste estudo é apontar, descrever e analisar as formas de transposição dos pressupostos brechtianos de teatro em $O$ render dos heróis, de José Cardoso Pires, e Felizmente há luar!, de Luís de Sttau Monteiro, e mostrar a relação dessas peças com o período anterior à Revolução de 25 de abril, especificamente na década de 1960 , marcada pelos processos de aplicação da censura.

A matriz brechtiana em $O$ render dos heróis e em Felizmente há luar!, além de ser a estética responsável por uma tentativa de inovação nas formas dramáticas praticadas em Portugal, confirma a preocupação dos autores com a expressão de um posicionamento crítico perante a realidade, com os rumos da dramaturgia e com o papel do dramaturgo em seu tempo e lugar. 


\title{
1 \\ A SITUAÇÃO DO TEATRO PORTUGUÊS NA DÉCADA DE 1960
}

\author{
Apesar dos obstáculos que, \\ absurdamente, impedem as suas \\ obras de cumprir o normal destino de \\ todas as criações dramáticas, \\ que é serem interpretadas num palco, \\ por actores, diante de um público, \\ os autores portugueses continuam \\ inevitavelmente a escrever para \\ o teatro. E essa teimosa persistência \\ é, sem dúvida, o mais seguro penhor \\ de que, nas suas mãos, a gloriosa \\ herança de Gil Vicente, de Ferreira, \\ do "Judeu", de Garrett, \\ não se extinguirá. \\ (Rebello, 1972, p.119)
}

Os críticos e historiadores da arte dramática portuguesa, ao avaliarem o desenvolvimento do teatro - como um todo ou mais especificamente da dramaturgia -, afirmam o "ressurgimento" (Vilaça, 1963b), a "evolução” (Rebello, 1972), um "movimento ascensional” (Rodrigues, 1961) do teatro português após a Segunda Guerra, principalmente na década de 1960. Até no olhar analítico mais distanciado 
no tempo há um reconhecimento, ainda que com emprego de termos menos entusiasmados, de um "desenvolvimento global e harmonioso" da atividade teatral portuguesa posterior a 1945 (Barata, 2001). Assim, o teatro, mesmo com a censura a estorvar-lhe o caminho, como veremos adiante, consegue não apenas resistir, mas manter suas criações dramatúrgicas em sintonia com as inovações estéticas do século XX, embora com algum natural atraso.

Em ensaio intitulado Panorama do teatro português contemporâneo, MárioVilaça(1963b, p.219), que acompanhava no calor da hora a atividade teatral, afirma acreditar no ressurgimento da literatura dramática em seu país devido ao fato de as editoras, desde 1958, "arriscarem-se" mais a editar teatro, e de ter aumentado consideravelmente o número de autores de peças teatrais, "não porque tudo o que se tem publicado seja bom. Mas, sim, porque já alguma coisa de bom apareceu, pelo menos bastante bom". Por outro lado, António Quadros (1964, p.204, grifo nosso) aponta, na produção teatral contemporânea, a falta de dramaturgos autênticos e critica a imitação de modelos europeus de teatro: "Arremedar o teatro de Paris não é criar o teatro português, nem, afinal, teatro que como tal possa ser considerado", mas admite que "Raul Brandão vai deixando de estar isolado na nossa nascente dramaturgia". Fernando Mendonça (1971, p.16), por sua vez, acredita que o teatro assume, pelo menos em parte, a mesma função de intervenção social que o romance e o conto neorrealistas desempenhavam na década de 1940, compartilhando a mesma ideia de que se trata de um fértil momento para a produção da dramaturgia:

O decênio de 1960 é o de maior florescimento teatral, teatro escrito, entenda-se. Uma plêiade de jovens escritores aventura-se decididamente a este meio de comunicação e produz (e está produzindo) um quantitativo surpreendente de peças que, se nem sempre apresentam um elevado nível 
dramático (ou épico), até porque são, de maneira geral, autores muito jovens, têm, contudo, o mérito de manter viva a literatura dramática em Portugal.

Vários novos autores nasciam na vida teatral portuguesa na década de 1960. Alguns deles eram já experientes romancistas e participavam pela primeira vez da criação teatral, ${ }^{1}$ muitos traziam ideias novas sobre a dramaturgia e a encenação captadas em outros países. Esse surto de autores certamente favoreceu a possibilidade de experimentação; assim, nos anos de 1960, as experiências estético-teatrais proliferavam em Portugal.

Muito da dramaturgia portuguesa da década de 1960 compartilha o mesmo princípio sustentado pela companhia do Teatro-Estúdio do Salitre, ${ }^{2}$ criada em 1946, que representou uma primeira tentativa de atualização do teatro em Portugal logo depois do fim da Segunda Guerra e "deu consciência à necessidade de libertar a cena portuguesa da hegemonia naturalista" (Rebello, 1972, p.107) do drama burguês.

A estética naturalista, como se sabe, visa objetivamente o efeito de ilusão de realidade no palco, de modo a trazer para a cena personagens que "vivem" o papel que desempenham, por meio de uma linguagem muito próxima da cotidiana, em cenários que procuram reconstituir a realidade. O espetáculo naturalista fornece ao público a sensação - ou a ilusão - de

1 Tanto Cardoso Pires como Sttau Monteiro estrearam na literatura dramática com as peças aqui em apreço. Antes disso, os dois escritores haviam publicado romances e contos. De Cardoso Pires destacamos Os caminheiros e outros contos (1949) e $O$ anjo ancorado (novela de 1958); e de Sttau Monteiro, Um homem não chora (1960) e Angústia para o jantar (1961).

2 Sob a direção de Luiz Francisco Rebello, Gino Saviotti e Vasco Mendonça Alves, o Teatro-Estúdio do Salitre foi instalado em uma sala do Instituto de Cultura Italiana, que possuía um diminuto palco, característica que deu ao grupo a designação de microteatro. 
estar diante de um acontecimento real, esquecendo-se, durante o tempo da encenação a que assiste, de que está, na verdade, diante de um acontecimento ficcional. Era isso que certa parcela dos artistas do teatro português começava a evitar. Assim, paulatinamente, assistia-se, "de peça para peça, a um distanciamento cada vez maior das estruturas e da linguagem tradicionais do teatro naturalista-realista" (idem, 1984, p.26).

Luiz Francisco Rebello aponta que "o experimentalismo, as preocupações sociais e a reflexão existencial" caracterizaram o teatro que se escreveu na primeira metade do período compreendido entre o fim da Segunda Guerra e o fim do regime salazarista. Do final dos anos de 1950 até 1974, "o teatro do absurdo e o teatro épico" interessaram sobremaneira os dramaturgos portugueses, pois

o recurso a uma linguagem crítica, a personagens e situações abstractas, que deformavam até ao absurdo a realidade circunstante, por um lado, e por outro a transposição do presente para factos e figuras exemplares do passado histórico, ou destas para aquele, eram as várias tentativas de dizer-se o que, directamente, a censura não consentia que se dissesse. (idem, p.25)

Além da integração de formas dramatúrgicas do teatro épico ou do teatro do absurdo no referido período, contribuiu para a definição de um "largo movimento de evolução contemporânea" do teatro, como constata Duarte Ivo Cruz (2001, p. 303), a constância das seguintes características:

[...] concentração num temário de análise e crítica social muito marcado e politicamente empenhado; tentativa de renovação das expressões cênicas e do espetáculo; visão cultural do teatro como um todo; certa irregularidade a nível de profissionalismo, com grande ênfase dada ao experimentalismo e à descentralização por via profissional e amadora; irregularidade da frequência de público, com uma clara passagem do 
teatro comercial, bom ou mau, para o teatro experimental ou culturalmente exigente, o que teve como efeito a médio prazo o desaparecimento da revista.

A incidência de temas de análise e crítica social e a busca por uma inovação dramatúrgica e cênica anti-ilusionista vão se filiar quase que naturalmente à "lição" de Brecht, ou seja, aos princípios norteadores do teatro épico brechtiano, que, como veremos, opõe-se ao teatro naturalista, criticando esse tipo de teatro em que o espectador se deixa levar pela cena apresentada, identificando-se com ela, sem proceder a qualquer julgamento ou reflexão.

A "fase nova de ressurgimento" e de "assinalável progresso" foram as características apontadas por MárioVilaça (1963b) na dramaturgia contemporânea, muito embora o ensaísta reconhecesse que as peças esperavam pela representação no palco.

O que suprimia a dimensão cênica das peças escritas não era a falta de grupos interessados em encená-las. São registradas no referido período novas companhias teatrais, entre elas: Teatro Moderno de Lisboa (TML, 1961), Teatro Estúdio de Lisboa (TEL, 1964), Teatro do Instituto Superior Técnico (IST, 1964), Grupo 4 (1967), Teatro Experimental de Cascais (TEC, 1965). E continuavam em atividade as principais companhias criadas nos anos de 1950: Teatro Experimental do Porto (TEP, 1952, tornando-se profissional em 1957), Círculo de Iniciação Teatral da Academia de Coimbra (CITAC, 1956), Cênico de Direito (Teatro da Associação Acadêmica da Faculdade de Direito, 1954). A maioria dessas companhias de teatro teve sua origem em grupos formados na universidade e elas tinham características comuns: buscavam efetiva participação do público; objetivavam levar o espectador à análise e à crítica do contexto político-social e, principalmente, reconheciam o teatro como instrumento de intervenção e de luta política 
e cultural. Graça dos Santos (2004, p.327) nos fornece uma descrição precisa dos espectadores desses teatros:

Graças ao teatro universitário (em particular o CITACe o Cênico de Direito), surge uma nova maneira de ser espectador. Era uma assistência entusiástica e jovem, proveniente sobretudo dos meios universitários. Não eram espectadores passivos e queriam compreender o fenômeno teatral e os seus diferentes processos. Na sua maioria tinham nascido sob o salazarismo, e só tinham conhecido um Portugal em que qualquer ideia original era sufocada pela censura, qualquer comportamento não conforme aos modelos impostos pelo Estado Novo era silenciado, mas tinham uma enorme sede de ideias novas, de par da exigência de uma universidade livre.

Nesse contexto em que o teatro é vigiado de perto pelos "conservadores salazarófilos" - para usar a expressão da mesma autora acima citada -, surgem, a partir de 1960, os dramas narrativos de tema histórico, adeptos do registro épico brechtiano, uns mais outros menos bem-sucedidos: $O$ render dos heróis (1960), de José Cardoso Pires; Felizmente há luar! (1961), de Luís de Sttau Monteiro; Bocage (1965), de Romeu Correia; O judeu (1966), de Bernardo Santareno; Bocage alma sem mundo (1967), de Luzia Maria Martins; A outra morte de Inês (1968), de Fernando Luso Soares; Quem move as árvores (1970), de Fiama Pais Brandão; Antonio Vieira (1973), de Fernando Luso Soares; Legenda do cidadão Miguel Lino (1973), de Miguel Franco.

A produção dramatúrgica, a publicação das peças teatrais, as experimentações e novas formas de encenação criadas e desenvolvidas pelas companhias de teatro que surgiam, tudo sofria a constante asfixia tanto da mão pesada da censura sobre os textos, quanto do olhar vigilante dos censores sobre os grupos de teatro e suas representações.

Diante disso, é importante vincular aos dados e características que aqui apontamos as formas de repressão 
praticadas pela censura salazarista, que impôs sua marca na história do teatro português.

\section{O teatro sob a mira da censura}

No extremamente longo e tenso período da ditadura em Portugal, as práticas da comissão de censura ${ }^{3}$ impuseram terror e medo aos escritores, intelectuais, dramaturgos e jornalistas, pela constante proibição e apreensão de obras e pela ameaça de prisão de seus autores, impedindo muitas vezes "que os meios de comunicação social mencionassem o título de obras proibidas e o nome do seu autor" (Rodrigues, 1980, p.77). A censura evitava esclarecer ou fundamentar uma decisão publicamente, e quando era necessário fazê-lo era breve e objetiva, impondo a redação da informação a ser publicada. Um telegrama telefonado da Comissão do Exame Prévio do Porto para a imprensa, reproduzido por Graça dos Santos (1980, p.75), ilustra bem o que afirmamos:

Foi proibida uma peça de teatro, adaptação de Correia Alves, do Arco de Sant 'Ana, no TEP (Teatro Experimental do Porto). Não dizer que foi proibida. Pode, no entanto, dizer-se que já não vai à cena. Capitão Correia de Barros.

O teatro foi um dos grandes alvos da censura, que reprimiu a produção de peças teatrais e proibiu a representação, nos palcos, de textos de autores portugueses ${ }^{4}$ e estrangeiros.

3 A partir de 1933, a censura passou a ser exercida por comissões. A Comissão de Censura de Lisboa exercia o papel de Comissão Central. A Comissão de Examee Classificação dos espetáculos, que tinha o seu presidente nomeado por Salazar, passou a avaliar e a classificar as peças de teatro, autorizando-as por inteiro ou com corte, ou proibindo-as.

4 Rebello (1984, p.13) fornece-nos os números: "É significativo que, das 79 peças compendiadas entre 1926 e 1974 e aqui [no seu livro] resumidas, 27 - cerca de 35\% - tenham sido banidas pela censura, 
O "lápis azul" 5 dos censores rasurava as palavras, frases e falas das peças - era, pois, a marca concreta da censura nos textos. Nos teatros, os censores se faziam presentes nas primeiras fileiras da plateia.

A ditadura salazarista promoveu em Portugal o conformismo, a apatia, a imutabilidade diante da realidade e a censura impôs o silêncio dentro e fora do país:

Como primeiro objectivo [a censura salazarista] procurou confinar as cidadelas culturais e todo o país, todo, a um isolacionismo que lhe facilitasse a imposição violenta das suas regras. Em segundo alcance pretendeu, e com algum êxito, elaborar em silêncio fechado certas máscaras contemporâneas para publicidade exterior. Seria, numa palavra, o "petit dictateur" que à custa do segredo cultiva as impunidades do abuso e exporta uma imagem tolerável no convívio internacional. Silêncio, portanto, no exterior. Pax intra muros. (Cardoso Pires, 1977, p.200)

Salazar, que comumente costumava subestimar a inteligência dos cidadãos (Rodrigues, 1980), entendia a censura como um "corretivo necessário" à organização da sociedade, como explica José Cardoso Pires em uma entrevista a Artur Portela (1991, p.38): "Salazar pretendia radicar, por exemplo, a censura como um hábito social, uma prática familiar de dissuasão, por assim dizer. Chamava-lhe resignadamente 'um mal necessário', como toda a gente sabe".

Na comparação entre a censura praticada durante o regime de Salazar e a aplicada pelo nazismo de Hitler, Graça dos Santos (2004, p.73) faz uma síntese esclarecedora:

das quais apenas 3 vieram a ser mais tarde autorizadas e outras tantas proibidas após a primeira série de representações".

5 Os censores suprimiam palavras ou frases inteiras riscando-as por completo com cor azul, daí a expressão "lápis azul da censura". Às vezes, apareciam comentários, geralmente em letra ilegível, nas margens dos textos, o que impossibilitava saber por quais motivos a obra havia sido censurada. 
As medidas de depuração e de destruição das obras literárias ou artísticas são, para as autoridades nazis, pretexto para grandes operações publicitárias em que o terror, o medo são exibidos. Essa é uma diferença essencial em relação ao salazarismo, que prefere confiscar discretamente as obras consideradas indesejáveis. Os esforços vão mais no sentido de abafar as resistências, tentando tudo para que não se manifestem [...]. Trata-se de evitar para não defrontar, mantendo para isso uma ilusão de harmonia, de um povo sereno e tranquilo.

Analisando a censura sofrida pelo teatro durante o Estado Novo, Luiz Francisco Rebello (1977) aponta três tipos: censura ideológica, censura econômica e censura geográfica. A proibição de espetáculos e textos teatrais estrangeiros ou portugueses era a arma do poder ditatorial para impedir o acesso do público àquilo que, para a comissão de censura, era "perigoso", "subversivo" ou simplesmente "suspeito"; assim, a arte coletiva por natureza, que é o teatro, sofria a censura ideológica. Os espetáculos escolhidos pelos empresários para lhes destinar patrocínio eram aqueles que agradavam ao público burguês que podia pagar o preço dos ingressos, constituindo-se, neste caso, uma forma de censura econômica. Já a censura geográfica se define, segundo Rebello (idem, p.26), pelo fato de a atividade teatral se concentrar quase que exclusivamente na capital do país, ou seja, ficava limitada "a cerca de nove décimos da população a possibilidade de assistir a espetáculos teatrais (possibilidade teórica, já que na prática a reduziam aos outros condicionamentos antes referidos)".

$\mathrm{Na}$ ditadura de Salazar, a aplicação da censura empregava ainda as formas preventiva e repressiva (Santos, 2004) a todo material de comunicação a ser veiculado em Portugal. As tipografias, por exemplo, antes de pôr um livro em circulação, eram obrigadas a submetê-lo às autoridades da segurança pública, que tinham poderes para fechar as 
gráficas que imprimissem material suspeito de "perturbar a segurança pública". ${ }^{6}$ No caso do teatro, o procedimento da censura era complexo. Escrita a peça, o autor ou grupo de teatro deveria submeter o texto ao exame do censor, que autorizava, autorizava com cortes ou proibia a obra. Comentam os escritores que muitas vezes os cortes feitos pelo famoso lápis azul do censor eram tantos que o texto ficava horrivelmente mutilado, tornando a peça irrepresentável. Se vencida a primeira etapa, ou seja, tendo o texto o carimbo "Visado pela Comissão de Censura", vinha a segunda: "ensaio de censura", que consistia em uma apresentação da peça no palco - com todo o figurino, a música, o cenário, a iluminação - para a supervisão do censor. Graça dos Santos (idem, p.273) registra o depoimento do encenador Fernando Gusmão, que descreve o ensaio de censura como "controlado por mais de dez censores que, cúmulo do ridículo, seguiam o texto com lanternas de bolso a fim de verificar a conformidade do texto dito com o texto visado pela censura". Nessa segunda etapa, também poderia haver "correções" ditadas pelo censor; então lá ia o grupo teatral fazer, em novos ensaios, as modificações exigidas, o que levava ao adiamento da estreia do espetáculo - e tempo e dinheiro eram perdidos. O sentimento que prevalecia nos autores era o do medo, além do estresse total. Por meio de suas práticas, a Comissão de Censura declarava aos artistas o domínio do poder político sobre o social:

Retrair o editor e apagar a presença social do escritor português eram dois lances do mesmo jogo que a Censura desenvolvia metódica e sistematicamente. Num conjunto de operações aparentemente dispersas, quer dificultando o apoio da imprensa ao autor, quer actuando directamente so-

6 Semelhante é o caso dos periódicos. A apresentação de provas dos jornais já paginados era obrigatória, sendo necessário fazer as alterações exigidas pela comissão em curto espaço de tempo. 
bre as editoras, quer ainda inspirando pressões indirectas por intermédio de vários ministérios, procurava-se isolar o autor nacional, tornando-o inconveniente às instituições privadas, dificultoso para a indústria do livro e socialmente inoperante ou irrepresentativo. (Cardoso Pires, 1977, p.231-2)

Os processos da censura - cujo principal objetivo era o domínio da comunicação -, além de desgastantes e humilhantes, constituíam uma ameaça para a obra e para o seu autor. A peça poderia sofrer algum tipo de mutilação ou o texto ser totalmente proibido. O dramaturgo corria o risco de ser preso, sem de fato saber o porquê, pois a dita comissão era desprovida de critérios, sendo a subjetividade do censor o que guiava sua avaliação de textos e espetáculos:

\section{Critérios?}

Não é necessário adiantar muitas explicações ou aduzir exemplos. Fundamentalmente, interessava [à comissão de censura] detectar o que poderia ser menos consonante com os valores que se tinham como únicos e, por isso mesmo, susceptíveis de "pôr em risco a segurança e a tranquilidade do país”. (Barata, 1991, p.353)

O censor, devido à deficiência de sua formação cultural (Cardoso Pires, 1977), quando não entendia uma sentença ou onde achava ter algo suspeito, cortava sem se preocupar com a consequência da mutilação feita nos textos.

Na década de 1960, a censura praticada pelo Estado Novo tornou-se ainda mais intensa: o Centro Português do Instituto Internacional de Teatro foi considerado ilegal, a Sociedade Portuguesa de Escritores foi extinta, ${ }^{7}$ a peça

7 Em nome da Sociedade Portuguesa de Escritores, um júri, formado pelos escritores Alexandre Pinheiro Torres, Augusto Abelaira, João Gaspar Simões, Manuel da Fonseca e Fernando Botelho, concedeu o prêmio da novela ao livro Luuanda, do escritor José Luandino Vieira, 
O motim, de Miguel Franco, foi impedida de continuar em cena - exemplo claro de censura repressiva - depois de apenas cinco apresentações do espetáculo, o que resultou em protestos e abaixo-assinados ${ }^{8}$ de intelectuais e artistas, repudiando o silêncio ao qual o teatro português estava sendo condenado.

Além da proibição de espetáculos, do impedimento da representação de determinadas peças nacionais, o público português também foi privado da encenação de peças de autores estrangeiros. Entre as dramaturgias estrangeiras proibidas deencenação nos palcos portugueses encontramos todas as peças de Bertolt Brecht, Jean-Paul Sartre, ${ }^{9}$ Peter Weiss, parte da produção de Jean Anouilh, Fernando Arrabal, Friedrich Dürrenmatt, Max Frisch, Eugène Ionesco, Alfred Jarry, Sean O'Casey, Erwin Piscator, Alfonso Sastree ainda especificamente as peças Julio César (William Shakespeare) e A mandrágora (Nicolau Maquiavel).

De acordo com Luiz Francisco Rebello (1977), mesmo com a liberação para a encenação de algumas peças portuguesas (O pecado de João Agonia, de Bernardo Santareno; As mãos de Abraão Zacut, de Luís de Sttau Monteiro; Forja, de Alves Redol) e de outras estrangeiras (Quem tem medo de Virginia Woolf?, de Edward Albee) na chamada Primavera Marcelista, a Comissão de Censura apenas

que se encontrava preso em cumprimento de uma sentença de 14 anos por ter lutado pela independência de Angola. Em represália, a sede da sociedade foi saqueada e depois extinta e os membros do júri interrogados pela Polícia Política.

8 O "Protesto contra a proibição da permanência nos palcos, em 1965, da peça O motim”, dirigido ao Ministro da Educação, é integralmente reproduzido por Rebello (1977, p.161-4).

9 Exceção para as peças A Respeitosa - no Brasil, A prostituta respeitosa -, de Jean-Paul Sartre, e A alma boa de Setsuan, de Brecht, que "só foram consentidas [em 1960] a uma companhia estrangeira (a companhia brasileira de que era directora e actriz Maria Della Costa)" (idem, p.30). 
mudou de nome os seus órgãos constituintes, mantendo as suas práticas e processos:

Com a subida de Marcelo Caetano ao poder [1968], o regime afivela uma nova máscara (sorridente) - embora o rosto permanecesse imutável. Tal como a polícia política e a União Nacional mudaram de nome $e^{10}$ e as colónias passaram a ser "províncias ultramarinas", a censura à imprensa crismou-se de "exame prévio" e a Comissão de censura aos espetáculos de "exame de classificação". (Rebello, 1977, p.31)

Outros escritores tinham igual percepção sobre o sucessor de Salazar: "O consulado de Marcelo Caetano procurava adaptar a subdoutrina de Salazar a um país desautorizado por fora e por dentro" (Portela, 1991, p.40), diz Cardoso Pires em entrevista. Até mesmo o discurso de um secretário do Estado, pronunciado em 1968, no Secretariado Nacional de Informação (SNI), atestava a imutabilidade da organização oficial da censura, como registra Graça Almeida Rodrigues (1980, p.71):

Nada mudou nesta casa; nem o espírito nem a devoção a valores essenciais, nem a linha de acção. Pelo contrário, há, cada vez mais, a forte vontade de cumprir aquilo que um dia, ao criar-se o SNI, foi afirmado por Salazar - de que nós tínhamos que dar aqui testemunho da verdade.

Obviamente, a repressão imposta pela censura do Estado Novo, ou "Estado Social" como queria Marcelo Caetano, fazia-se sentir no enredo das peças de teatro, de forma

10 Em 1968, por motivo de doença, Salazar é obrigado a se afastar do poder e assume o governo Marcelo Caetano, que alterou o nome da PIDE (Polícia Internacional de Defesa do Estado) para DGS (Direcção Geral de Segurança) e da União Nacional para Acção Nacional Popular (ANP). Também rebatizou o regime (Estado Novo) de Estado Social. 
indireta, pela alegoria. Uma característica da dramaturgia desse período é que não foram poucos os dramaturgos que recorreram à história documentada do país em busca de matéria para compor a fábula de suas peças, sendo essa releitura do passado um pretexto para provocar uma reflexão sobre o momento presente. Tratava-se de criar com isso mecanismos de resistência ao regime:

Os autores, não poucas vezes confrontados com um doloroso processo de autocensura, cedo se deram conta que seria necessário tornear as cada vez maiores dificuldades que a censura lhes levantava. Influenciados pelas lições estéticas bebidas no exílio europeu, encontraram na fábula histórica ou - como alguns preferem na parábola histórica - uma forma (disfarçada é certo!) de recuperar as raízes populares historicamente documentadas. Assim, a releitura da nossa história permitia apresentá-la não como passado intocável e institucionalizado, que os ideólogos da ditadura erigiam como epopeia permanente em torno dos grandes mitos nacionais expostos através de conhecida retórica nacionalista. Mergulhar no passado era, antes de mais, fornecer o exemplo (ou exemplos) para, através da reflexão crítica, apelar à acção, tomando consciência de que, apesar da história não se repetir, o passado assume um enorme peso na interpretação do presente. (Barata, 1991, p.356, grifos do autor)

Pensando nos núcleos temáticos de origem histórica das peças produzidas durante o Estado Novo, Barata (idem) faz um levantamento de temas dos quais se apropriaram os dramaturgos desse período. Assim, encontramos o mito do sebastianismo, as revoluções - marcadamente a Revolução Liberal do Porto, em 1820 - e personalidades históricas como temas da dramaturgia portuguesa ao longo de um período de quase quarenta anos. ${ }^{11}$

11 O levantamento dos temas relativos à história de Portugal, feito por 
É preciso aqui esclarecer que essa retomada do passado por meio da história não deve ser confundida com a do tradicional drama histórico do século XIX, ${ }^{12}$ que expressava o ideário romântico da busca ou do fortalecimento da identidade nacional. Diferentemente disso, a matéria histórica, principalmente se unida à estética teatral proposta por Bertolt Brecht - como era o caso de algumas dessas fábulas históricas dos anos 1960 e 1970 -, objetivava levar o espectador a refletir sobre as questões e os problemas da atualidade, posicionando-se criticamente.

Em 1960, José Cardoso Pires publica O render dos heróis - fábula histórica de matriz brechtiana-, abrindo o caminho para que outros dramaturgos seguissem a mesma estética de teatro "que significava afinal uma forma de resistência velada à ditadura então vigente” (Delille, 1991b). A peça sobe ao palco em 1965, pelo Teatro Moderno de Lisboa, ${ }^{13}$ tendo a

Barata (1991), apresenta peças publicadas desde a década de 1940 especificamente, em 1949, a peça El Rei Sebastião, de José Régio-e vai até 1982 com peças de Hélder Costa, JoséSaramago, Luzia Maria Martins, Sinde Felipe e Romeu Correia.

12 Segundo Rebello (1972, p.86-7), a partir de 1886 "as peças de tema histórico multiplicam-se. Não obstante haver nelas um rigor maior na pintura dos costumes evocados e, sobretudo, na sua representação cênica, $[. .$.$] bem como um evidente esforço de adesão aos princípios$ naturalistas, a verdade é que o modelo de quase todas continuava a ser o que, mais de meio século antes, Vitor Hugo havia traçado e Sardou repusera em uso".

13 O Teatro Moderno de Lisboa (1961-1965) foi uma importante companhia dirigida por Rogério Paulo, Costa Ferreira e Fernando Gusmão. Nas palavras de Mário Vilaça (1963, p.212), o TML, ao iniciar suas atividades com a encenação da peça $\mathrm{O}$ tinteiro, de Carlos Muniz, "veio arejar a bafienta e rotineira situação do teatro profissional de Lisboa, procurando fazer um teatro mais vivo, mais actual e actuante, mais renovador”. Graça dos Santos (2004, p.307) considera a encenação, em 1965, de O render dos heróis um marco não só para o teatro português, mas também uma coroação do TML: "Tanto pelo texto [O render dos heróis] e suas ressonâncias brechtianas como pela encenação de Fernando Gusmão, esta criação não só surge 
direção de Fernando Gusmão. Devido à reação positiva do público, a encenação chama a atenção dos censores, ${ }^{14}$ que se dão conta do "equívoco" em tê-la autorizado. Depois de algumas apresentações, o espetáculo fica "limitado à cidade de Lisboa, com proibição, em simultâneo, de qualquer publicidade a anunciá-lo" (Santos, 2004, p.275). Porém, nos dias em que esteve no palco, a divulgação boca a boca manteve o teatro lotado.

Felizmente há luar! foi proibida de ser encenada em Portugal pela Comissão de Censura da ditadura de Salazar. À época de sua publicação em livro, a crítica foi unânime em conferir à obra de Sttau Monteiro indiscutível qualidade estética e os críticos, talvez acreditando na força de seus elogios, pediam a encenação da peça:

Agora podemos dizer que, efectivamente, teatro temos, pelo menos um teatro em potência, uma dessas fontes dramáticas que, graças à sua enraizada trama humana na própria intra-história da inteligência portuguesa, nada poderá estancar, nem sequer a hipótese absurda de não termos actores para representar tão admirável tragédia e a não menos absurda hipótese de esta obra-prima nunca chegar a ser representada. (Simões, 2004, p.142-3)

É isso que quero registar, porque é meu dever que o faça e porque é verdadeiro e porque estes dois actos [de Felizmente

como momento culminante da companhia, comoé paradigmática da evolução que se opera no teatro português entre a década de 1960 e a década de 1970". O TML, por falta de recursos - não tinha apoio financeiro privado nem estatal -, foi obrigado a encerrar suas atividades em 1965 e $O$ render dos heróis foi o seu último espetáculo.

14 Rebello(1977, p.38) explica que, quando a eficácia de uma encenação se mostrava consideravelmente diminuída junto ao público, a peça deixava de ter sobre si o olhar vigilante da censura. Assim, o contrário também é verdadeiro; a eficácia junto ao público chamava a atenção dos censores. 
há luar!] gritam por uma encenação que ponha à prova as qualidades irrefutáveis desta peça a todos os títulos extraordinários de Sttau Monteiro. Ao ser levada à cena, a prova do palco só virá a justificar as minhas afirmações e comprovará as enormes possibilidades e a invulgar potencialidade dramática de uma peça que já nos empolga à simples leitura. (Vilaça, 1962, p.137)

Vilaça (1963b, p.220) volta a elogiar a peça de Sttau Monteiro, um ano depois, fazendo o mesmo apelo: "esta peça merece ser aqui referida e clama por uma encenação imediata e inteligente se os ventos censórios estiverem de feição”. Felizmente há luar! foi levada à cena - mas fora dos palcos portugueses - pelo Teatro Oficina Português de Paris, em 1969, com direção de Carlos César, ${ }^{15}$ e finalmente pôde ser encenada em Portugal ${ }^{16}$ em 1978, com direção do próprio Sttau Monteiro, no Teatro D. Maria II.

Depois da Revolução dos Cravos, Felizmente há luar! e $O$ render dos heróis perderam alguns dos atributos tão positivos mencionados à época pelos críticos; porém, as duas peças conservam ainda hoje a força poética e a qualidade dramática.

No contexto político repressivo em que surgiram essas obras de teatro, os autores experimentavam novas formas dramatúrgicas que pudessem expressar e despertar uma

15 Carlos César, como muitos artistas e intelectuais portugueses, por motivos políticos ficou exilado até 1974 na França, onde deu continuidade à sua atividade teatral, criando o Teatro Oficina Português de Paris, cujo trabalho manifestava a clara oposição ao regime salazarista.

16 Felizmente há luar! teve encenações recentes nos palcos de Portugal: de 2001 a 2008, com montagem do TEP (Teatro Experimental do Porto), direção de Norberto Barroca; de 2006 a 2009, com encenação do grupo teatral A barraca, na direção de Helder Costa, tendo esta montagem participado da "III Mostra Latino-Americana de Teatro de Grupo”, realizada no Centro Cultural de São Paulo, em maio de 2008. 
visão crítica do momento presente. Assim, em Portugal, a dramaturgia produzida nesse período - narrativa e anti-ilusionista - foi a que mais expressou a necessidade de analisar criticamente a realidade e, justamente por isso, a que mais se prestou à resistência ao regime político vigente, tendo sofrido, pois, a mais vigorosa censura.

\section{A obra brechtiana em Portugal}

Na primeira metade do século XX, a cada peça escrita a dramaturgia portuguesa se afastava cada vez mais da linha naturalista de teatro. Fosse pelo "experimentalismo, tributário em grande parte da técnica pirandelliana de desmontagem dos mecanismos em que se assenta a convenção teatral" (Rebello, 1984, p.25), fosse pelo teatro do absurdo ou pela teoria épica brechtiana, os dramaturgos faziam suas escolhas estéticas. Entre essas linhas, tracemos brevemente o percurso do teatroépico brechtiano em Portugal, pois é nesse registro que as peças que nos interessam se inserem.

Segundo Maria Manuela Gouveia Delille(1991a), algumas poucas informações sobre a obra de Bertolt Brecht em Portugal começam a aparecer na década de $1940,{ }^{17}$ em um jornal da imprensa neorrealista, preocupado com o papel social da arte, e no semanário O Diabo (1934-1940), de crítica literária e artística, ligado a setores oposicionistas, que publica a tradução de um trecho do texto de Brecht "Cinco dificuldades ao escrever a verdade", integrando um conjunto de artigos que tinham como tema a função do escritor no mundo. De 1945 a 1949 - ainda conforme o levantamento de Delille(idem) - não há registros sobre o conhecimento da

17 De acordo com a mesma autora, antes da década de 1940 somente há "umas brevíssimas alusões [a Brecht] feitas por Julio Dantas, em 1925” (Delille, 1991a, p.63). 
obra de Brecht pelos artistas portugueses e, provavelmente, isso se deve à escassez de edições das obras brechtianas, à dificuldade com a língua alemã e à inexistência, até meados dos anos de 1950, de traduções de Brecht para o inglês e para as línguas latinas. As primeiras referências, de fato, à obra de Brecht datam de 1949, são de autoria de Luiz Francisco Rebello - grande crítico, historiador do teatro português e dramaturgo, que contava na época com apenas 25 anos de idade - e foram publicadas principalmente no periódico Vértice - Revista de Arte e Cultura, que evidenciava "forte empenhamento político-social de raiz marxista" (idem, p.64), fazendo, pois, oposição à ditadura salazarista.

Na segunda metade da década de 1950, os portugueses começaram a ter acesso à obra de Brecht primeiramente pela tradução francesa, e os poucos artigos então publicados em Portugal-apesar dos esforços dos apreciadores de Brecht em explicar e divulgar a teoria do teatro épico e a obra dramática do dramaturgo alemão - apresentavam certas reduções ou equívocos sobre a estética brechtiana como, por exemplo, a afirmação de que Brecht pregava a falta de emoção do ator e, por conseguinte, também do espectador.

Em 1955, José Redondo Júnior (1955, p.241) afirma estar "apaixonadamente interessado no estudo de Geneviève Serreau sobre o grande dramaturgo, encenador e teatrólogo alemão Bertolt Brecht, [...] que apresentou Mère Courage, a mais espantosa revelação". Entusiasmado com a obra brechtiana, o teatrólogo e jornalista português tece, nesse mesmo artigo, algumas considerações sobre o teatro épico. No final da década de 1950, de acordo com Delille (idem), é Luiz Francisco Rebello o grande divulgador das ideias e da obra de Brecht. Rebello publica, em 1957, em seu Teatro Moderno, a tradução para o português da peça $A$ exceção e a regra. Em 1961, Redondo Júnior publica o livro Panorama do Teatro Moderno, em que trata de estéticas teatrais, explica o famoso efeito- $V$ brechtiano e apresenta a tradução - feita 
a partir da versão francesa - de fragmentos das peças Mãe Coragem e seus filhos e $O$ círculo de giz caucasiano. Além de Luiz Francisco Rebello e Redondo Júnior, Mário Vilaça também foi um importante propagador da obra de Brecht em Portugal nos anos de 1960 e publica ensaios na revista Vértice sobre o teatro brechtiano.

O interesse pela obra dramática e pelas teorias brechtianas de teatro aumenta consideravelmente entre 1958 e 1968 , despertando cada vez mais o desejo dos artistas portugueses em levar aos palcos as peças do dramaturgo alemão. Assim, houve, por exemplo, uma tentativa da Cia. Rey ColaçoRobles Monteiro de encenar Mãe Coragem e seus filhos, de Brecht, mas foi sempre impedida pelo Conselho de Leitura, ou seja, censura prévia ao texto. ${ }^{18}$

Nesse tempo, o regime salazarista passava por um momento de crise, abalado pelas eleições presidenciais de $1958^{19}$ e pela formação de guerrilhas nas colônias africanas, na década de 1960, em luta pela independência. Diante da crise, a ditadura intensificou ainda mais os mecanismos de repressão no país. Como o teatro era sempre o maior alvo da Comissão de Censura salazarista, a obra dramática de Brecht continuou banida dos palcos portugueses, salvo raríssimas exceções.

Como aponta Rebello (1977), poucas encenações da obra de Brecht realizadas por companhias estrangeiras ou por grupos universitários foram autorizadas, mas nem

18 A correspondência trocada pela atriz Amélia Rey Colaço com os representantes alemães da obra de Brecht é mencionada por Graça dos Santos (2004) e registrada por Maria Manuela Gouveia Delille (1991b).

19 A candidatura de Humberto Delgado à presidência, concorrendo com o candidato do regime, Américo Tomás - que ganha as eleições-, foi um grande movimento de oposição a Salazar. É famosa a frase de Delgado em uma entrevista em que, quando perguntado sobre o que faria em relação a Salazar se ganhasse as eleições, ele imediatamente responde: "Demito-o". 
sempre lhes era permitido permanecer em cena e cumprir a prevista temporada de espetáculos. É famoso o caso da peça A alma boa de Setsuan, levada à cena em Portugal, no ano de 1960, pela Companhia do Teatro Popular de Arte do Brasil - também conhecida como Companhia de Maria Della Costa, atriz que fez o duplo papel de Chen Te e Chui Ta. Após cinco apresentações tumultuadas por protestos de intelectuais de extrema-direita e pela reprovação do espetáculo pela imprensa situacionista lisbonense, a encenação foi proibida pela censura. Na imprensa da época, ${ }^{20}$ registraramse demonstrações de repúdio ao "escritor comunista", referência a Brecht, e à peça, cujos três deuses, personagens que nela aparecem, foram interpretados como uma "alusão desrespeitosa à Santíssima Trindade”. Todas as peças de Brecht continuaram proibidas de subir à cena.

Mesmo na chamada "Primavera Marcelista" - que Cardoso Pires ironizou como "Inverno Marcelista" - não houve nenhuma mudança no que se refere à proibição das obras de Brecht nos palcos lusos. O público português foi privado de conhecer encenações das peças de Brecht até 25 de abril de 1974 .

$\mathrm{Na}$ tentativa de burlar a censura, fragmentos de obras teatrais ou poemas de Brecht eram introduzidos, sem a citação do nome do autor, em espetáculos teatrais autorizados. Não foram poucas as tentativas de levar à cena as obras brechtianas, e uma ou outra encenação de grupos universitários era possível, desde que apresentada somente a alunos. Durante a década de 1960, ficaram por conta do teatro amador ou universitário as encenações "fechadas"

20 A maior referência até o momento sobre a recepção de Brecht em Portugal é o valiosíssimo trabalho orientado e organizado por Maria Manuela Gouveia Delille (1991b). No livro, as autoras apresentam cópias dos artigos publicados na imprensa da época, referentes à encenação de A alma boa de Setsuan pela companhia de Maria Della Costa. 
ou as representações clandestinas ou semiclandestinas de trechos da obra dramática de Brecht, que obviamente alcançavam apenas um pequeno público:

É o caso de A excepção e a regra em 1960, pelo Círculo de Iniciação Teatral da Academia de Coimbra (encenação de Ricard Salvat), e de cenas extraídas de diferentes peças, apresentadas pelo Grupo Cênico da Associação de Estudantes do Instituto Superior Técnico (IST), durante o ano escolar de 1968-1969, sob a direcção de Mário Sério. É o reduzido alcance desses espetáculos, com um público muito restrito, que permitia o seu [de Brecht] esporádico aparecimento. (Santos, 2004, p.277)

A Comissão de Censura foi, entretanto, menos rígida em relação à publicação em livro da obra dramática de Brecht. Inicialmente as peças foram sendo traduzidas parcial ou integralmente e publicadas em artigos de periódicos ou em livros sobre estética teatral. No início da década de 1960, a Portugália Editora começa um projeto de divulgação da obra dramática do autor de Mãe Coragem e seus filhos, sendo essa peça e A alma boa de Setsuan integrantes do primeiro volume da série Teatro I, com tradução para o português de Ilse Losa, ${ }^{21}$ escritora alemã radicada em Portugal.

A teoria do teatro épico era de grande interesse entre os autores portugueses, que viam nos pressupostos de Brecht

21 A tradução de Ilse Losa é bastante criticada por Mário Vilaça. A tradutora publica carta em resposta às críticas do ensaísta e ele lhe responde. Mesmo sem conhecer a tradução de Losa, fica difícil não dar razão a Mario Vilaça (1963a, p.89), pois ao lermos a carta da tradutora em defesa própria encontramos muitos erros de português, fato que o ensaísta não deixa de criticar: "tenho de dizer-lhe [a Ilse Losa] que, como tradutora, tem mostrado sempre, em tudo o que escreve, que não sabe português. Por isso mesmo se chamou a atenção para os erros excessivos de português que uma simples carta sua, de quatro páginas dactilografadas, nos exibe. Eles bastam só por si para me dar razão". 
a possibilidade de uma inovação no teatro de então e, por isso, procuravam compreender e explicar em seus artigos as técnicas brechtianas. Tornava-se claro que o teatro épico se realiza, de fato e efetivamente, na encenação, sendo a dramaturgia, o texto, apenas parte do fenômeno teatral. Por isso, os divulgadores das ideias de Brecht clamavam por encenações das peças do dramaturgo. Em realidade, as peças de Brecht - como grande parte da dramaturgia portuguesa produzida nessa época - eram conhecidas por meio do livro e não do palco. O teatro de Brecht em Portugal era lido e não encenado.

Segundo José Redondo Júnior (1961, p.45), a "reinvenção do teatro" - e para ele o efeito-V de Brecht é "um dos fatores essenciais da mais moderna reinvenção do teatro" - se dá principalmente pela ação do encenador, mais que pelo trabalho do dramaturgo, e destaca a montagem épica da peça de Friedrich Dürrenmatt, com encenação de Cayetano Luca de Tena, na temporada de 1959/60 no teatro D. Maria II, fazendo, em seu comentário, uma clara referência ao famoso esquema de Brecht que opõe a forma épica à forma dramática de teatro:

É que, em A Visita [da Velha Senhora, de Dürrenmatt], está bem expressa a fórmula brechtiana: a cena conta a acção; torna o público espectador dessa acção; desperta a actividade do espectador; o espectador opõe-se à acção; o teatro funciona por argumentos; o homem muda; o ser social condiciona o pensamento. (idem, p.44, grifo do autor)

Mas diante da situação em que se encontrava o teatro português - silenciado nas páginas dos livros, quando muito, ou encerrado nas gavetas dos dramaturgos - a representação épica estava um tanto distante da realidade. Antes das traduções portuguesas da obra de Brecht, notícias sobre o teatro épico acabavam chegando ao país 
e os meios de se obter conhecimento da obra brechtiana e assimilá-la eram os mais variados:

Quer através da leitura de traduções brechtianas francesas e/ou inglesas e de estudos sobre a nova dramaturgia, quer através de estadas mais ou menos longas na França, Inglaterra ou Alemanha, onde assistem à representação de peças de Brecht por companhias europeias célebres, alguns dos nossos mais conhecidos escritores, encenadores e actores adquirem conhecimentos seguros sobre a teoria e a prática do teatro épico, que logo procuram transpor para a criação literária ou para a praxis teatral próprias. (Delille, 1991a, p.73)

Obviamente, as ideias teatrais de Brecht não foram acolhidas por todos. Críticas e questionamentos aos pressupostos brechtianos de teatro apareciam aqui e ali. João Gaspar Simões, por exemplo, deixava claro em seus artigos um certo desdém pelas técnicas brechtianas, principalmente se empregadas na dramaturgia portuguesa, embora reconhecesse o mérito de peças como $O$ render dos heróis e Felizmente há luar!. Mesmo os escritores e dramaturgos expressavam certa cautela em comentários sobre o teatro épico. O fato de esse teatro ser definido como antiaristotélico e de ter o ator como principal responsável pelo alcance do efeito de distanciamento são os questionamentos mais comuns. $\mathrm{O}$ que ocorre, na verdade, é que no final da década de 1960 a importância do teatro de Brecht começa a ser relativizada pelos intelectuais e artistas portugueses, apesar de ressurgir o interesse pela obra do dramaturgo alemão logo depois da Revolução de 25 de abril e suas peças passarem a ser das mais encenadas em Portugal na década de 1970.

No âmbito da recepção reprodutiva dos pressupostos brechtianos no período que nos interessa, a frequência de dramas portugueses de caráter histórico narrativo "é claro testemunho, por parte dos escritores nacionais, de leituras brechtianas ou de contacto directo com a obra do drama- 
turgo alemão em palcos estrangeiros, sobretudo franceses e ingleses" (idem, p.81). Tal produção dramatúrgica filia-se a Brecht para reafirmar o seu caráter de resistência às formas repressivas do Poder instituído, em uma tentativa de libertação da expressão artística e do pensamento crítico. 



\section{2 \\ Algumas CONSIDERAÇões SOBRE O TEATRO ÉPICO DE BRECHT}

Necessitamos de um teatro que não nos proporcione somente as sensações, as ideias e os impulsos que são permitidos pelo respectivo contexto histórico das relações humanas

(o contexto em que as ações se realizam), mas, sim, que empregue e suscite pensamentos e sentimentos que desempenhem um papel na modificação desse contexto. (Brecht, 2005, p.142)

Muito já se escreveu sobre Bertolt Brecht (1898-1956), sua obra teórica, sua literatura dramática, seu teatro vivo, seu pensamento, suas ideias, suas contradições, sua posição política, antes e depois de sua morte, ontem e ainda hoje. Assim, encontramos comumente o Brecht dramaturgo, o Brecht poeta, o Brecht político, o Brecht polêmico, os "pecados de Brecht" (Arendt, 1999)... Ou, ainda, em uma visão mais abrangente e de dimensão filosófica, o conjunto que une a linguagem, o pensamento e a prática narrativa de 
Brecht. ${ }^{1}$ Sobre a personalidade e a vida do autor alemão há também um grande número de referências espalhadas pelo mundo. As palavras de Hannah Arendt (idem, p.194-5) sobre Brecht definem a personalidade, no mínimo curiosa, do dramaturgo:

Este, então, era o homem: dotado de uma inteligência penetrante, não teórica, não contemplativa, que ia ao centro do assunto, silencioso e relutante em se revelar, distante e provavelmente também tímido, de qualquer forma não interessado em si mesmo, mas incrivelmente curioso (de fato "o Brecht sedento de conhecimento", como se referiu a si mesmo na "Canção de Salomão", em A ópera dos três vinténs) e, primeiro e acima de tudo, poeta - isto é, alguém que tem de dizer o indizível, que não consegue ficar quieto nas ocasiões em que todos estão quietos, e portanto deve ter cuidado em não falar demais sobre coisas de que todos falam.

No que se refere especificamente ao teatro, Brecht dividiu opiniões, fez com que toda espécie de críticos se voltasse a favor ou contra suas ideias teatrais "pessoais ou tomadas de empréstimo” (Szondi, 2001), visse em suas cenas, para o bem e para o mal, um certo didatismo, uma pedagogia a ser seguida ou ainda algo de formalismo em sua concepção e técnicas de distanciamento; assim, "naturalmente as ideias de Brecht colocam problemas e suscitam resistências" (Barthes, 1999, p.131). Há, porém, uma unanimidade entre tantos que opinaram sobre o "escrevinhador de peças"2 que está no

1 Jameson (1999, p.53) propõe o que ele denomina "triangulação com Brecht”, ou seja, que nenhuma das áreas ou dimensões do trabalho de Brecht - linguagem, modo de pensar, narrativa - tem qualquer prioridade sobre as outras, mas que "elas podem ser vistas como tantas outras projeções umas das outras em diferentes meios, assim como um fenômeno cristalino poderia assumir diferentes aparências no domínio de ondas de luz enquanto permanece o 'mesmo"'.

2 SegundoWilma Rodrigues (1970-1971), Brecht evitava escrever em 
reconhecimento da dramaturgia brechtiana como obra de grande força criativa e inovadora do teatro moderno, apesar de a discussão a respeito de Brecht ter também se voltado mais tarde para a questão da atualidade ou não de seu teatro épico. Não cabe aqui fazer tal julgamento, embora consideremos as posições de Roberto Schwarz (1999) e Sérgio de Carvalho (2009) 3 especialmente enriquecedoras para a compreensão do porquê dessa discussão, ainda que eles se refiram mais especificamente ao contexto brasileiro.

O Brecht que nos interessa neste momento éo "encaminhador de propostas", como ele mesmo se definiu (Jameson, 1999), o que não significa necessariamente excluir por completo de nossas considerações sua poesia, por exemplo. Sobre os escritos sistemáticos de Brecht, Barthes (1999, p.136) atenta que "não é de modo algum enfraquecer o valor criativo desse teatro [épico brechtiano] considerá-lo como um teatro pensado". Assim, interessa-nos o trabalho teórico sobre o teatro épico proposto pelo dramaturgo alemão.

A teoria teatral desenvolvida por Brecht aparece um tanto dispersa ${ }^{4}$ em sua obra de reflexão e registro

primeira pessoa em seus textos teóricos sobre teatro e empregava preferencialmente o termo Stückeschreiber - escritor de peças de teatro - no lugar de "dramaturgo". Nos trabalhos de Ingrid D. Koudela sobre o dramaturgo aparece a expressão "escrevinhador de peças" como tradução do termo alemão.

3 Sérgio de Carvalho - na posição de encenador de obras de Brecht e representante do grupo paulistano de teatro Cia. do Latão-descreve o episódio em que Roberto Schwarz explica "as razões pelas quais Brecht perdeu a atualidade" e procura refutar os posicionamentos do crítico.

4 Apesar de Brecht dedicar um ensaio às formas de representação épica - "A nova técnica da arte de representar" -, muitas das técnicas indicadas por ele são descritas em outros textos; por exemplo, encontramos descrições mais precisas sobre o trabalho do ator em "Pequeno órganon para o teatro" (Brecht, 2005, p.125-66), ensaio que contém um prólogo e 77 breves parágrafos sobre os termos que emprega para expressar sua ideia de teatro. 
teóricos, devido à sua proposta de experimentação e de trabalho sempre em processo que caracterizou a práxis de seu teatro. Estudiosos de Brecht, no entanto, agruparam as técnicas teatrais recomendadas por ele de acordo com as várias partes do todo que compõem a cena dita épica. Sendo assim, é de consenso que o alcance do efeito de distanciamento - elemento caracterizador do teatro épico - envolve principalmente o trabalho do ator, uma certa caracterização do espaço cênico e a forma de utilização da música no palco. Faz-se necessário citarmos aqui, como exemplo, a descrição sucinta da obra de dois autores que organizaram os pressupostos teóricos brechtianos de teatro, tornando-se uma referência para os leitores de língua portuguesa, e comentarmos rapidamente um ensaio e uma tradução de autores portugueses sobre o teatro de Brecht. Essas obras de autores brasileiros e portugueses nortearam a fundamentação teórica do nosso estudo.

O teatro épico, de Anatol Rosenfeld (2006), cuja primeira ediçãoé de 1965, apresenta um percurso histórico do gênero épico a partir da teoria dos gêneros e mostra que os traços narrativos no teatro aparecem já na tragédia grega. Além disso, o livro reúne, no que diz respeito especificamente à teoria de Brecht, as técnicas de distanciamento em um conjunto de recursos classificados como: literários; cênicos e cênicos-literários; cênicos-musicais e, por último, o ator como narrador. Os recursos literários tratam principalmente da comicidade, já que "Um dos recursos mais importantes de Brecht, no âmbito literário, é, pois, o cômico, muitas vezes levado ao paradoxal" (idem, p.157), e se inserem aí a paródia e a ironia como processos que desempenham a função cômica, visto que para se produzir o riso é necessário distanciar-se da situação que o provocou. Nos recursos cênicos e cênicos-literários está a utilização de cartazes, títulos, projeções de textos que comentam de forma narrativa as ações, "teatralizando" a literatura e também tornando a 
cena literária. Os recursos cênicos-musicais utilizam coros e cantores que se dirigem diretamente ao público. $\mathrm{O}$ ator da representação épica, para trabalhar o efeito de distanciamento, dirige-se não só aos que estão no palco, mas também diretamente ao público. Clareando a ideia de representação cênica de Brecht, Rosenfeld (idem, p.161) explica que o ator “deve 'narrar' o seu papel, com o 'gestus' de quem mostra um personagem, mantendo certa distância dele".

O filósofo brasileiro Gerd Bornheim(1992), em seus estudos sobre a estética teatral de Brecht, parte das tendências do naturalismo e expressionismo no teatro e chega aos trabalhos de Brecht, que examina da juventude até a maturidade do autor alemão. Bornheim explica, na nota introdutória, que o tema do seu livro está "na evolução e no ordenamento das ideias estéticas do dramaturgo". Na terceira parte do ensaio, a que aqui mais nos interessa, Bornheim explica o efeito de distanciamento a partir do público - para quemé estabelecida a finalidade do distanciamento; a partir do ator-principal responsável pelo alcance do efeito no palco; a partir das cenas, dos elementos cênicos e da música, mostrando o tratamento estético que Brecht deu aos seus songse, finalizando, Bornheim faz algumas considerações a respeito do distanciamento a partir do diretor - ainda que, como ele mesmo afirma, Brecht não tenha deixado registros a esse respeito - e comenta, no final, peças e ensaios do dramaturgo.

No contexto do teatro português, a tradução que em 1964 Fiama Pais Brandão fez da coletânea dos textos teóricos de Brecht, organizada por Sigfried Unseld, tornou-se uma obra de referência (em Portugal e no Brasil), assim como os ensaios que divulgaram o teatro épico brechtiano em Portugal, de autoria de Luiz Francisco Rebello, Redondo Júnior e Mário Vilaça. Embora os textos desses autores tenham sido escritos, em sua maioria, depois de terem sido publicadas as peças que aqui analisamos, são fundamentais para se ter uma noção da compreensão da teoria brechtiana naquele país. $\mathrm{O}$ 
importante ensaio de Mário Vilaça, Do teatro épico (1966), por exemplo, preocupa-se em elencar e esclarecer algumas das "noções erradas que muito vulgarmente se ouvem por aî" a respeito da teoria brechtiana. Citando Anatol Rosenfeld, o ensaísta português esclarece que o teatro épico "não pretende eliminar ou destruir a emoção", que o teatro épico "opõe-se à catarse, mas à catarse como único objectivo do drama", que, apesar de o teatro épico se opor ao naturalismo e ao palco à italiana, "não se conclua daí, como é frequente, que sãoépicas todas as peças não naturalistas". MárioVilaça explica também que a diversão faz parte do teatro épico e que a peça épica não pode ser confundida com a chamada "peça de tese" ou "peça de propaganda" e, por último, queo teatro épico não se deixa "limitar ao campo do psicologismo e da interpretação psicológica”. Parece-nos, ainda, que um ponto conclusivo de MárioVilaça (idem, p.273) nos dá uma medida do que para ele interessa no teatro épico: "O desafio lançado pelo teatro épico é, em última análise, a criação de um teatro responsável socialmente enquanto conteúdo e ousado artisticamente enquanto forma”.

Nãoé nossa pretensão continuar a fazer aqui uma síntese de cada historiador de teatro, teórico, estudioso, ensaísta que se debruçou sobre a obra teórica de Brecht, porque isso seria praticamente impossível. A nossa intençãoé apresentar algumas considerações sobre as propostas teóricas de Brecht acerca do seu teatro épico com o objetivo de preparar um pouco o caminho que a seguir se abrirá para a análise das duas peças consideradas os primeiros frutos da perspectiva brechtiana de teatro em Portugal.

\section{O olhar épico da distância}

Ao longo de quase trinta anos, Bertolt Brecht escreveu uma variedade de textos a respeito da sua teoria teatral, 
que foi, até sua morte, em 1956, complementada, alterada, revista. Ao lermos os ensaios brechtianos, precisamos considerar o fato de que sua obra teórica apresenta os resultados e as reflexões de sua práxis teatral, refletindo, pois, as atividades desempenhadas por Brecht como dramaturgo, teórico e encenador - junção efetiva, portanto, da teoria e da prática. Nesses textos, encontram-se, em uma abordagem complexa, os famosos termos empregados pelo dramaturgo alemão na composição de sua teoria: teatro épico, efeito de distanciamento (Verfremdungseffekt), ${ }^{5}$ gestus social, conceitos de difícil definição. Os ensaios teóricos de Brecht contêm também descrições de encenações de peças de sua autoria, que ele próprio dirigiu, ou de outros exemplos de peças que ele, como atento espectador, assistiu; apresentam críticas ao teatro naturalista, ao qual o seu teatro épico se opõe, e contestação dos pressupostos aristotélicos de dramaturgia, como é sabido.

O registro da teoria brechtiana, principalmente por grande parte ser fruto das experiências de Brecht no palco, não escapou de ser transformado em uma verdadeira fórmula de encenação por realizadores do espetáculo teatral. Para Fernando Matos Oliveira (1997), o próprio Brecht acabou contribuindo para que seus apontamentos fossem

5 O termo "Verfremdungseffekt", com que Bertolt Brecht designa o princípio básico de sua dramaturgia, já foi traduzido para o português como "distanciamento", "efeito de distanciação", "estranhamento", "efeito-V” e até "alienação" (termo advindo de algumas traduções francesas). Em Portugal, Renato Correia (1985), ao defender o termo estranhamento como o melhor para a tradução para o português, criou um debate em torno do assunto, sendo contestado por António Sousa Ribeiro (1985). Maria Manuela Gouveia Delille (1991a / 1991b) utiliza o termo "estranhamento". MarioVilaça(1966) prefere a tradução "efeito de estranhamento ou efeito de alheamento". Anatol Rosenfeld (2006) escreve "efeito de distanciamento (Verfremdungseffekt = efeito de estranheza, alienação)”. Gerd Bornheim (1992) também utiliza o termo "distanciamento". No presente trabalho, utilizamos distanciamento, efeito- $\mathrm{V}$ ou o termo em alemão. 
vistos como receituários quando elaborou o famoso quadro em que contrapõe as características do teatro dramático às do teatro épico. É preciso lembrar, no entanto, que o tratamento que o dramaturgo alemão dá à forma de seu teatro constitui um método ou sistema próprio. Brecht sabia da dificuldade que é descrever o estilo de representação épica e das tentativas de encenação que se fizeram fora de seu domínio, muitas vezes levadas a banalizações e equívocos, ${ }^{6}$ como a "aparência de que se pretende eliminar tudo o que seja emocional, individual, dramático etc." (Brecht, 2005, p.222). Por outro lado, Brecht foi o primeiro a reconhecer que seu teatro épico não apresentava nenhuma novidade ${ }^{7}$ e reiterou inúmeras vezes que seu projeto teatral era um experimento, que o processo estava em andamento, que as experiências constantes de encenação o faziam rever e reformular suas ideias, muitas das vezes complementadas pelos companheiros de teatro, atuantes e colaboradores, como a atriz Helene Weigel, o cenógrafo Caspar Neher, o músico Kurt Weill e outros compositores.

O teatro épico também foi designado por Brecht como "teatro não aristotélico" devido às suas oposições a certos pressupostos que o filósofo grego faz em sua Poética. O ponto principal dessa oposição, como se sabe, refere-se à questão da identificação com o herói por parte do espectador:

A identificação é uma das vigas-mestras sobre as quais repousa a estética dominante. Na sua admirável Poética,

6 No texto "De uma carta a um ator", Brecht lamenta a interpretação equivocada, segundo ele, de seus escritos sobre a arte de representar e atribui isso à sua forma de redação: "Tal impressão provém, decerto, da minha maneira de escrever, que toma demasiadas coisas por evidentes. Maldita maneira!" (Brecht, 2005, p.253).

7 Vilaça(1966, p.264) aponta nas peças históricas de Shakespeare "poderosos traços épicos" por evocar o ambiente social das personagens, "enquadradas na evolução dialéctica dos acontecimentos". 
Aristóteles já descreve como, por meio da mimesis, é produzida a catarsis, isto é, a purificação da alma do espectador. $\mathrm{O}$ ator imita o herói (Édipo ou Prometeu) com uma tamanha força de sugestão e uma tal capacidade de metamorfose, que o espectador imita o imitador e toma para si o que vive o herói. [...] O que gostaria de dizer-lhes, agora, é que toda uma série de tentativas no sentido de fabricar, com os meios do teatro, uma imagem manejável do mundo, conduziram a suscitar a questão perturbadora de saber se, por isso, não seria necessário abandonar de alguma forma a identificação. É que, se não se considera a humanidade (suas relações, seus processos, seus comportamentos e suas instituições) como alguma coisa de dado e imutável, e se se adota em relação a ela a atitude que se teve, com tanto sucesso desde alguns séculos, em relação à natureza, essa atitude crítica que procura transformar a natureza, com o objetivo de a dominar, então não se pode recorrer à identificação. Impossível identificar-se com seres transformáveis, participar de dores supérfluas, abandonar-se a ações evitáveis. (idem, 1967, p.135, grifo do autor)

A partir dessa perspectiva, Brecht irá se perguntar o que aconteceria ao espectador se lhe fosse proibida "a atitude passiva, embebida de sonho, do homem lançado ao seu destino" e sugere que o espectador deveria ser introduzido, bem desperto, em seu mundo real, já que toda a dramaturgia brechtiana postula que "a arte dramática deve menos exprimir o real do que significá-lo” (Barthes, 1999, p.133). Nessa linha de pensamento, Brecht desenvolve a proposta primordial do teatro épico, queé a de narrar os acontecimentos relacionados à realidade, com o objetivo de despertar o senso crítico no espectador diante das cenas apresentadas. Para explicar o efeito da "técnica de identificação" e o da "técnica de distanciamento", Brecht toma como exemplo a cólera de Lear - Rei Lear, de Shakespeare -, devida à ingratidão de suas filhas. Segundo Brecht, usando a técnica de identificação o ator representa a cólera de Lear de modo 
que o espectador irá considerá-la a coisa mais natural do mundo. Por outro lado, usando a técnica de distanciamento, o ator representa a mesma cólera de Lear de forma tal que restará ao espectador "a possibilidade de se espantar com ela, de imaginar, para Lear, outras reações possíveis além da cólera" (Brecht, 1967, p.137).

Objetivar a reflexão e a crítica não quer dizer, no entanto, negar completamente a emoção, como se poderia pensar. $\mathrm{O}$ fato de Brecht contestar especificamente a teoria da catarse não significa que ele irá suprimir totalmente a possibilidade de emoção da sua teoria de teatro. O que ocorre no teatro épico brechtiano é a rejeição daquela emoção que visa à identificação do público com a cena, com a personagem, e leva o espectador ao plano da ilusão. O que Brecht sugere, na verdade, é um deslocamento das emoções - por meio de um tipo de atuação do ator e da utilização de determinados recursos - que provoca outras e novas formas de emoção, elevando o espectador ao plano da reflexão, da análise, da crítica. E isso só pode se dar por meio do Verfremdungseffekt, que ele propõe no lugar da identificação, da catarse aristotélica, como proposta de "tornar efetivamente possível um prazer artístico fundado no princípio do distanciamento" (idem, p.140).

Muitos estudiosos das letras e do teatro viram na obra Mãe Coragem e seus filhos, de Brecht, uma grande possibilidade de o espectador se emocionar com essa mãe, que no meio da guerra vai perdendo cada um de seus filhos. O efeito de distanciamento é capaz de transformar essa emoção que leva à entrega total do espectador, fazendo-o abandonar-se a ela - Brecht chama de "empatia por abandono" - em um outro tipo de emoção que leva à análise crítica da situação narrada, e disso vai depender muito o trabalho de atuação do ator. Na explicação de Brecht (2005, p.81), o efeito de distanciamento "não se apresenta sob uma forma despida de emoções, mas, sim, sob a forma de emoções bem deter- 
minadas, que não necessitam encobrir-se com as da personagem representada", o que significa que nãoé pela empatia apenas que a emoção pode ser desencadeada: "Perante a mágoa, o espectador pode sentir alegria; perante a raiva, repugnância”. Brecht propõe, então, o distanciamento no lugar da empatia.

É de consenso entre os teóricos de teatro que o efeito de distanciamento também não é uma invenção de Brecht ${ }^{8}-$ ele próprio apontou o distanciamento em obras teatrais e pictóricas nas feiras anuais da Alemanha, e reconheceu-o nas pinturas surrealistas. Muitas definições de Verfremdungseffekt foram apresentadas por Brecht em seus ensaios. Segundo Jameson (1999, p.63-4), o termo "parece ter migrado do ostranenie ou 'ato de tornar estranho' dos formalistas russos depois de inúmeras visitas a Berlim por soviéticos modernistas como Eisenstein ou Tretiakov". Como se sabe, Brecht analisou o Verfremdungseffekt principalmente na arte dramática chinesa em Efeitos de distanciamento na Arte Chinesa, ensaio que "representa a primeira discussão abrangente que Brecht empreendeu sobre o conceito capital de Verfremdung” (Carlson, 1997, p.372-3). Jacques Desuché (1966, p.67) afirma que "Brecht no se presentó jamás como el inventor de este célebre 'efecto $V$ '. Desarrolló la doctrina, no creó la cosa: el 'efecto $V$ ' se manifiesta ya en ciertas circunstancias de la vida cotidiana".

Estranhar algo que nos é habitualmente familiar, a partir do momento em que somos chamados a prestar detida atenção àquilo que nos é comum, é a manifestação do distanciamento presente na vida cotidiana. Brecht ilustra esse tipo de distanciamento com o famoso exemplo

8 Rosenfeld (2006, p.152) mostra que Schiller exigia o distanciamento para aumentar a grandeza do espetáculo com a introdução do coro: "Enquanto Schiller, em última análise, almeja um estado estéticolúdico, apartado da vida imediata, Brecht se empenha, através da mediação estética, pela ativação política do espectador”. 
de perguntar a um interlocutor se ele já parou para olhar atentamente seu relógio (do interlocutor); ao fazê-lo a pessoa toma a distância necessária para a análise daquele objeto tão familiar. Para os gregos, explica Anatol Rosenfeld (2006, p.155), o distanciamento provocava a surpresa que "se afigurava como o início da investigação científica e do conhecimento", o que não deixa de significar uma espécie de despertar diante do que se apresenta como comum. Por isso que, no palco, tudo se conjuga de forma tal para que o espectador se conscientize de que nada que foi apresentado na cena "é inevitável ou inalterável”, é nisso que "reside a força da produção épica [...], nessa convicção e no ensinamento de que a história e a natureza humana não são imutáveis, havendo sempre a possibilidade de nos transformarmos e de transformarmos o mundo" (Vilaça, 1966, p.274). É nesse sentido que está a dimensão ou formulação política do efeito- $\mathrm{V}$ :

Aqui, o familiar ou habitual é novamente identificado como "natural" e seu estranhamento desvela aquela aparência, que sugere o imutável e o eterno, e mostra que o objeto é "histórico". A isso deve-se acrescentar, como corolário político, que é feito ou construído por seres humanos e, assim sendo, também pode ser mudado por eles ou completamente substituído. (Jameson, 1999, p.65)

Em sua práxis teatral, Brecht (2005, p.146) criou técnicas que tencionam provocar no espectador essas duas reações, a de surpresa e a de estranheza, a fim de produzir o distanciamento:

As oscilações surpreenderam-no [Galileu, quando contemplava o lustre que oscilava], como se jamais tivesse esperado que fossem dessa forma, como se não entendesse nada do que se estava passando; foi assim que descobriu a lei do pêndulo. $\mathrm{O}$ teatro, com as suas reproduções do convívio 
humano, tem de suscitar no público uma visão semelhante, visão que é tão difícil quanto fecunda. Tem de fazer que o público fique assombrado, o que conseguirá, se utilizar uma técnica que o distancie de tudo que é familiar.

O espectador do teatro épico, ao se distanciar, assume uma posição analítica perante os acontecimentos narrados nas cenas. Com efeito, o distanciamento ativa uma reação no espectador, tira-o da passividade, coloca-o no movimento da reflexão. Nesse sentido, podemos dizer que o distanciamento produz o efeito contrário da empatia, a qual, para Brecht, pode levar o espectador à marginalização do espírito crítico, já que se identificar com a cena significa reconhecer-se nela, envolver-se com ela, impossibilitando, pois, um momento de afastamento para o despertar de uma reação crítica. Na explicação de Rosenfeld (2006), estando identificados com as coisas corriqueiras, não as vemos com o "olhar épico da distância" e ficamos abandonados à situação habitual que nos parece eterna; é só por meio do distanciamento que nós mesmos e a nossa situação podemos nos tornar objetos de nosso juízo crítico.

O teatro épico empenha-se em ensinar ao espectador "um determinado comportamento prático com vista à modificação do mundo, deve suscitar nele uma atitude fundamentalmente diferente daquela a que está habituado" (Brecht, 2005, p.47); é notório, pois, o caráter didático ${ }^{9}$ desse tipo de teatro, que, muitas vezes, justamente por essa razão, foi largamente criticado. Não é nosso propósito abrir aqui uma discussão sobre a função da arte dramática, porém a questão do elemento didático como proposta presente - às

9 Brecht (1967, p.127) reconhece que a tentativa mais radical de conferir caráter didático ao teatro foi empreendida por Erwin Piscator: "Participei de todas as suas experiências [de Piscator]; nenhuma delas que não tenha tido por objetivo desenvolver a função didática da cena". 
vezes de forma mais indireta - na obra teórica de Brecht deve ser considerada.

Rosenfeld (2006) aponta duas razões pelas quais o teatro épico se opõe ao aristotélico. A primeira é que não pretende apenas apresentar relações entre os indivíduos, mas as "determinantes sociais dessas relações", e a segunda é que o homem deve ser visto no "conjunto de todas as relações sociais”. A essa segunda razão liga-se o "intuito didático” do teatro de Brecht: "O fim didático exige que seja eliminada a ilusão, o impacto mágico do teatro burguês” (idem, p.148). Para Bentley (1991, p.318), o que surpreende na obra de Brecht é como o dramaturgo transforma suas lições em obra de arte: "Pode deixar de ser arte se a alegoria for direta e ponderada ou se a propaganda for ansiosa e importuna. Brecht consegue escapar dessas armadilhas, e o resultado é alguma coisa inteiramente nova no teatro didático”. A intenção didática de Brecht vai, a cada peça, encerrando o ciclo do teatro didático que o dramaturgo havia iniciado com $O$ voo de Lindberg (1929). O que se pode dizer é que suas peças continuam conscientemente pedagógicas, mas não essencialmente didáticas (Bornheim, 1992), porque as técnicas utilizadas por ele são, então, transformadas. Não se pode negar, de resto, que no conceito de distanciamento está inserido o caráter pedagógico - afinal, provoca-se o afastamento do espectador justamente para que ele apreenda a realidade e aprenda com ela.

Se o espírito crítico despertado no público não exclui a possibilidade de provocar também a emoção, como vimos, o mesmo acontece com a caracterização do teatro como um meio de diversão. Segundo Willett (1967), o teatro épico passa a ser justificado como entretenimento (diversão) por Brecht depois que o dramaturgo escreve a peça Vida de Galileu (1938-1939). A partir de então, Brecht começa a interpretar sua própria obra mais em termos científicos que políticos, registrando, aliás, suas ideias nessa direção em seu 
ensaio "Pequeno órganon para o teatro" (1948), considerado por alguns críticos e teóricos uma síntese ou plataforma da teoria do teatro épico.

Emoção e diversão são, portanto, reações, ligadas ao prazer estético, admitidas na teoria teatral de Brecht, para quem o teatro tem como função divertir: "O teatro consiste na apresentação de imagens vivas de acontecimentos passados no mundo dos homens que são reproduzidos ou que foram, simplesmente, imaginados; o objetivo dessa apresentação é divertir" (Brecht, 2005, p.127, grifo do autor). A diversão da qual fala o dramaturgo está intrinsecamente relacionada ao espírito da crítica científica, porque o público é o da era científica e "exige um tipo de entretenimento que reflita a visão moderna e científica da realidade" (Carlson, 1997, p.379). $\mathrm{O}$ valor dado ao divertimento como um objetivo essencial do teatro liga-se àquele sentimento de surpresa-que Anatol Rosenfeld (2006) aponta nos gregos - diante da descoberta, do conhecimento, e também demonstra a preocupação de Brecht (2005, p.67) em defender o teatro épico de ser julgado como "profundamente desagradável, tristonho e fatigante", o que certamente não interessaria a nenhum público.

As condições necessárias ao palco e à sala de espetáculos, para se alcançar o efeito de distanciamento, indicam que não se deve produzir nesses espaços nenhum clima de magia, nenhum "campo de hipnose", nenhuma forma de ilusão, e "a propensão do público para se entregar a uma tal ilusão deve ser neutralizada por meios artísticos” (idem, p.104); são esses meios artísticos, desenvolvidos por meio de determinadas técnicas, que vão caracterizar a encenação épica.

Para tratar do Verfremdungseffekt, precisamos ter em conta alguns pressupostos extraídos dos textos teóricos de Brecht sobre as técnicas de distanciamento, lembrando que "as próprias técnicas têm um significado simbólico próprio, elas são apenas meios para se atingir um fim" (Jameson, 1999, p.64). 
A responsabilidade da encenação épica para Brecht recai principalmente sobre a atuação do ator, que precisa trabalhar um determinado tipo de representação a fim de alcançar o distanciamento. Além das técnicas desenvolvidas para o ator, há também outros recursos recomendados pelo dramaturgo que contribuem para a caracterização da cena épica.

As duas primeiras partes que propomos a seguir para a abordagem dos pressupostos do teatro de Brecht são, ao fim e ao cabo, apenas para demarcar dois trabalhos que se assemelham e se completam nas formas de teatralização; a terceira parte, por sua vez, procura definir e caracterizar a fábula brechtiana. Sem querer traçar aqui uma comparação reducionista entre Brecht e os dramaturgos portugueses, apenas afirmamos que a fábula desenvolvida tanto por Cardoso Pires quanto por Sttau Monteiro, guardado o estilo de cada autor, aproxima-se das características que apontamos na definição da fábula brechtiana.

\section{Encenação épica: o ator mostra o teatro, o espectador analisa a realidade}

Em sua teoria do teatro épico, Brecht dedica especial atenção à atividade do ator e descreve detalhadamente o trabalho que este deve desempenhar para resultar a representação épica que é determinante para o alcance do efeito de distanciamento. Segundo Brecht (2005, p.50), o ator da cena épica "deverá esforçar-se para que o espectador reconheça nele um intermediário entre si e o acontecimento". É, portanto, principalmente a partir do trabalho proposto ao ator que as técnicas de distanciamento são desenvolvidas e atingem seus objetivos.

A atuação do ator descrita por Brecht em seus ensaios sobre estética teatral, como sempre, provém do trabalho 
prático, de uma série de exercícios realizados durante os ensaios das peças. Bornheim (1992, p.275) afirma que não se pode falar de uma teoria brechtiana do ator; no entanto, "o trabalho do ator funciona como uma espécie de portal de acesso a questões essenciais de todo o teatro de Brecht". Em suas notas sobre peças e encenações, Brecht descreve a atuação de seus atores, e tal descrição funciona em seus textos não apenas como ilustração, mas como fundamentação para sua teoria.

$\mathrm{O}$ ator ideal do teatro épico deve ter uma visão essencialmente crítica da realidade, "e mais ainda, tal crítica deve fazer-se no presente do trabalho artístico do ator - e é dentro desse contexto que surge o cultivo do distanciamento" (idem, p.261). Assim, exige-se do ator o mesmo posicionamento crítico que o teatro épico quer despertar no espectador.

Na prática, Brecht propõe um intenso trabalho teatral ${ }^{10}$ antes dos ensaios e, por parte do elenco, uma concentrada leitura da peça de modo que os atores entendam que, mais que decorar frases, o importante é fixar as partes do texto que chamam a atenção, assumindo, com isso, uma atitude de surpresa e, ao mesmo tempo, de contestação diante dos acontecimentos narrados (Brecht, 2005).

Além dos escritos teóricos, encontramos também nos poemas de Brecht referências à arte de representar. O poema

10 Referimo-nos à explicação e à definição dadas por Pavis (2007, p.412, grifo do autor) ao trabalho teatral: "Este termo - talvez uma tradução inconsciente do Modelbuch brechtiano que leva o título de Theaterarbeit (1961) - teve nos anos cinquenta e sessenta uma grande voga, pois evocava não só o estrito trabalho dos ensaios e do aprendizado do texto pelos atores, mas também a análise dramatúrgica, a tradução e a adaptação, as improvisações gestuais, a busca do gestus, da fábula ou a abertura do texto a uma pluralidade de sentidos, a marcação dos atores, a preparação dos figurinos, dos cenários, das luzes etc. Trabalho teatral implica assim uma concepção dinâmica e operatória da encenação". 
"O mostrar tem que ser mostrado" praticamente explica e sintetiza um exercício de atuação:

Mostrem que mostram! Entre todas as diferentes atitudes

Que vocês mostram, ao mostrar como os homens se portam Não devem esquecer a atitude de mostrar.

A atitude de mostrar deve ser a base de todas as atitudes.

Eis o exercício: antes de mostrarem como

Alguém comete traição, ou é tomado pelo ciúme

Ou conclui um negócio, lancem um olhar

À plateia, como se quisessem dizer:

Agora prestem atenção, agora ele trai, e o faz deste modo.

Assim ele fica quando o ciúme o toma, assim ele age

Quando faz negócio. Desta maneira

O seu mostrar conservará a atitude de mostrar

De pôr a nu o já disposto, de concluir

De sempre prosseguir. Então mostram

Queoquemostram, toda noitemostram, jámostraram muito E a sua atuação ganha algo do fazer do tecelão, algo

Artesanal. E também algo próprio do mostrar:

Que vocês estão sempre preocupados em facilitar

$\mathrm{O}$ assistir, sem assegurar a melhor visão

Do que se passa - tornem isso visível! Então

Todo esse trair e enciumar e negociar

Terá algo de uma função cotidiana como comer,

Cumprimentar, trabalhar. (Pois vocês não trabalham?) E

Por trás de seus papéis permanecem

Vocês mesmos visíveis, como aqueles

Que os encenam.

(idem, 2000, p.241)

$\mathrm{Na}$ cena, o ator deve mostrar-se ator e esta atitude de tudo mostrar, além de ser a condição necessária para a produção do efeito de distanciamento, é responsável por eliminar a noção de quarta parede - que separa ficticiamente o palco da plateia e da qual advém o efeito de ilusão -, impedindo o ator de produzir o efeito da empatia. 
Ao assumir essa atitude de desvendar os mecanismos da interpretação, o ator - assim como também a encenação como um todo - lembra ao público que ele (espectador) está no teatro. Nas palavras do ensaísta português Mario Vilaça (1966, p.274):

Tudo [na encenação épica brechtiana] é teatro. O espectador tem de sentir que está realmente no teatro e que tudo que ali se passa é apenas representação. Ao sair, não deverá sentir-se emocionalmente satisfeito, mas, sim, intelectual e socialmente insatisfeito.

Todos os propósitos da atuação épica convergem para o mesmo objetivo que é o de o ator atuar de "forma que se veja, tanto quanto possível claramente, uma alternativa, de forma que a representação deixe prever outras hipóteses e apenas apresente uma entre as variantes possíveis" (Brecht, 2005, p.106); por isso, o ator em cena não chega nunca a se transformar completamente na personagem que representa, porque, na verdade, é como se sua atuação no palco estivesse fazendo uma proposta. Nesse sentido, para uma representação épica, que não deve pretender a metamorfose total e integral do ator na personagem, Brecht (idem, p.107) sugere "três espécies de recursos para distanciar a expressão e a ação da personagem apresentada: 1. recorrência à terceira pessoa. 2. recorrência ao passado. 3. intromissão de indicações sobre a encenação e de comentários". A recorrência ao passado permite ao ator a "retrospecção das falas", distanciando-as, sendolhe possível, com essa atitude distanciada, pronunciar-se sobre qualquer fala. Os recursos 1 e 3 se completam porque tal "intromissão" geralmente se faz na terceira pessoa, possibilitando ao ator comentar uma situação e/ou fazer indicações da própria encenação. Em algumas passagens de seus textos teóricos, Brecht afirma que a recorrência a 
tais recursos se dá nos ensaios e também pode ocorrer na apresentação do espetáculo.

Em seus registros, Brecht descreve a representação da atriz Helene Weigel na encenação de A mãe - peça inspirada na obra homônima de Máximo Gorki (1868-1936) - como exemplo de interpretação do ator em uma encenação épica. Brecht inicia suas notas definindo a peça:

A mãe, escrita no estilo das peças didáticas, mas exigindo atores, é uma peça de concepção dramática antimetafísica, materialista, não aristotélica. Essa arte dramática não explora, tão decididamente como a arte dramática aristotélica, a tendência que há no espectador para uma empatia por abandono; revela, além disso, uma atitude essencialmente diversa, em relação a determinados efeitos psicológicos, tal como, por exemplo, a catarse". (idem, p.47, grifo do autor)

No papel de Pelagea Wlassowa, Helene Weigel profere sua fala, segundo Brecht, como se fosse na terceira pessoa, expõe a personagem diante do espectador "como agente e como objeto da reflexão". Em determinados momentos a atriz pronuncia as frases em voz alta; em outros, em voz clara, categórica, e prolonga, por exemplo, o som da palavra "sim" em tom de falsete, e Brecht sintetiza: "Era como se estivesse representando para uma roda de políticos - sem que por isso fosse menos atriz ou saísse dos domínios da arte" (idem, p.53).

Anatol Rosenfeld (2006, p.161) define claramente as funções do ator da representação épica brechtiana que, com o objetivo de interromper ou eliminar qualquer processo de ilusão - ou seja, o processo catártico -, deve mostrar a personagem:

Em cada momento [o ator] deve estar preparado para desdobrar-se em sujeito (narrador) e objeto (narrado), mas também para "entrar" plenamente no papel, obtendo a 
identificação dramática em que não existe a relativização do objeto (personagem) a partir de um foco subjetivo (ator). [...] Na medida em que o ator, como porta-voz do autor, se separa do personagem, dirigindo-se ao público, abandona o espaço e o tempo fictícios da ação.

O ator-narrador, ao se dividir em "pessoa" e "personagem”, toma uma posição frente aos fatos apresentados e em face da personagem, assumindo ele (o ator) o ponto de vista da crítica social (idem). Para Brecht, o ator não abandona nunca o papel de narrador e é nesse momento que, em seu desempenho, cabe perfeitamente o uso da terceira pessoa. Ao apresentar a personagem como se estivesse descrevendo alguém que lhe é estranho - e aqui poderá empregar a terceira pessoa-, o ator não deve se esquecer de que quem está em cena não é a pessoa descrita, mas a que descreve, e suas opiniões (do ator) não estão em sintonia com as de quem é descrito. Jameson (1999, p.85) comenta que a representação em terceira pessoa ratifica a natureza "imaginária" do eu e o mantém a distância no palco.

Para explicar o papel do narrador na encenação épica, Brecht se vale da narração dos acontecimentos que podem ocorrer em qualquer esquina de rua. As cenas de rua, ${ }^{11}$ para o dramaturgo, são o exemplo-padrão da encenação épica em que o indivíduo que descreve e narra a cena interrompe-a com explicações e comentários de tal forma a distanciar o acontecimento narrado:

11 Brecht (2005, p.90) recorre a acontecimentos que podem se desenrolar em qualquer esquina de rua, por exemplo: "a testemunha ocular de um acidente de trânsito demonstra a uma porção de gente como se passou o desastre". Segundo ele, esseé um exemplo de teatro épico na sua forma primitiva e explica que a cena de rua estabelece, pois, uma afinidade com esse tipo de teatro. No seu ensaio "As cenas de rua - Esquema de uma cena de teatro épico”, a partir do exemplo citado, Brecht explica a forma de representação épica. 
A transcrição direta da representação ao comentário, que caracteriza o teatro épico, é o elemento que logo à primeira vista encontramos numa descrição levada a efeito na via pública, seja ela qual for. O indivíduo que efetua a descrição na via pública interrompe com explicações, tantas vezes lhe pareçam convenientes, a sua imitação. (Brecht, 2005, p.98)

Quanto mais for interrompido aquele que narra (atua), mais claramente percebemos seu gesto, por isso "la interrupción de la acción ocupa el primer plano en el teatro épico" (Benjamin, 1987, p.19). A partir do momento em que o ator passa a reparar em seu próprio gesto e a realizá-lo cuidadosamente, realça a importância do acontecimento narrado, dando-lhe notoriedade e provocando, então, o distanciamento do espectador.

Assim, vinculada ao trabalho do ator está uma determinada linguagem gestual ou, como escreve Brecht, em latim, o gestus, que, na forma de o ator mostrar-se como tal, isto é, como ator, exibe suas atitudes em cena, assume uma posição. $\mathrm{O}$ ator mostra seu próprio gesto, destacando-o, como em uma moldura, de modo a obrigar o espectador a nomear o gestus executado, dando-lhe uma significação elevada. Esse gestus do qual fala Brecht é diferente daquele gesto convencional, conhecido do público, como, por exemplo, um movimento de cabeça para dizer sim ou não. O gestus, na realidade, 'é 'vago', desconhece a convenção prefixada, ou só poderia aceitá-la acidentalmente, e o que está em causa nele é o próprio sentido ou a intenção básica do espetáculo" (Bornheim, 1992, p.284). Podemos dizer que o gestus adquire uma particularidade de caráter social quando representa uma realidade essencial ou uma providência assumida; é, então, "significativo para a sociedade, que permite tirar conclusões que se apliquem às condições dessa sociedade" (Brecht, 2005, p.238). Assim, identificado como social e histórico, o gestus se desvincula 
de uma natureza humana eterna e de uma caracterização arquetípica: ${ }^{12}$

o gestus envolve claramente todo um processo no qual um ato específico - na verdade, um ato particular, situado no tempo e no espaço e vinculado a indivíduos concretos específicos - é assim identificado e renomeado, associado a um tipo mais amplo e mais abstrato de ação em geral, e transformado em algo exemplar (mesmo porque a palavra arquetípico não nos interessa mais). (Jameson, 1999, p.143, grifo do autor)

A exteriorização do gesto é algo extremamente complexo, pois implica as atitudes que as personagens exibem umas em relação às outras. Para o trabalho do ator, é-lhe sugerida a arte da observação de material gestual colhido da realidade: na vida cotidiana, nas cenas de rua, nos meios de comunicação. Um exemplo desse tipo de observação, que pode formar o repertório dos atores, é fornecido por Willi Bolle (1986), que apresenta a descrição de uma cena da peça Mãe Coragem e seus filhos na qual a gestualidade da atriz Helene Weigel - elaborada por meio da observação de uma foto de imprensa em que uma mulher aparece curvada ao lado do filho morto, durante o bombardeio de Cingapura - e a expressão de dor de Mãe Coragem pela perda do filho remetem à cena da foto: "O ato da mimese, realizado pelo ator segundo um original, corresponde a um processo de pensamento - um pensamento corporal, pois a aprendi-

12 Jameson (1999, p.143) faz, em nota, uma distinção entre a terminologia nada brechtiana dos tipos e do típico e seu uso lukacsiano: “em Lukács o ‘típico’ opera principalmente como uma categoria classificatória de personagens - uma restrição que claramente confina o grande crítico húngaro a um realismo bastante tradicional com seus sujeitos estáveis e psiques centradas. O que é 'típico' no gestus brechtiano é a própria ação, e também [...] os vários componentes ou elementos de construção da ação, irreconhecíveis daqui por diante: aqui o sujeito estável e reconhecível sai de cena". 
zagem do ator consiste em transmitir o gestus a seu corpo inteiro" (idem, p.27). Dessa forma, o gestus está também relacionado à expressão do corpo, objetivando a percepção do todo por meio de detalhes significativos.

Na prática brechtiana, muito do que se construiu sobre o teatro épico foi sendo desenvolvido durante os ensaios, com os exercícios de representação propostos por Brecht. Em carta a um ator ${ }^{13}$, Brecht acentua, entre outros temas, a importância da qualidade artística, de saber falar com clareza, de utilizar o dialeto do povo, e explica sua exigência de o ator não se transformar na personagem. Para isso, o dramaturgo critica a forma naturalista de representação, na qual "floresceu o princípio absolutamente estéril de que 'compreender tudo é tudo perdoar"”, e em seguida descreve o trabalho do ator segundo uma "nova orientação":

Tem [o ator] de tomar posição, intelectual e emocionalmente, em relação às personagens e às cenas. A nova orientação que se exige do ator não é uma operação fria, mecânica; o que é frio e mecânico não se coaduna com a arte, e esta nova orientação é, justamente, de natureza artística. Se o ator não estabelecer uma autêntica ligação com o seu novo público, se não tiver um interesse apaixonado pelo progresso humano, essa nova orientação não poderá concretizar-se. (Brecht, 2005, p.254)

Fica evidente que a representação épica exige do ator uma tomada de posição frente aos acontecimentos, certamente a mesma que se exige do espectador do teatro épico diante da cena apresentada. ${ }^{14}$

13 "De uma carta a um ator" é a resposta de Brecht a um ator que pergunta se a exigência de que o ator não se transforme totalmente na personagem não torna "a representação um acontecimento puramente artístico, mais ou menos desumano” (Brecht, 2005, p.253).

14 Jameson (1999) aventa a possibilidade de se pensar que o ator talvez 
É de responsabilidade do ator mostrar no palco suas atitudes revestidas de um gestus sobrepessoal, por isso social, oferecendo assim, ao espectador, motivos de reflexão. Nessa relação entre o que o ator mostra e comenta e o que o espectador assiste e analisa se realizam o princípio e o objetivo da cena épica.

Toda a teoria brechtiana de teatro, como temos reiterado, pressupõe a representação cênica: "É a encenação que dará a aplicação total à concepção épica, que não é parcelar e se completa no todo constituído pelo teatro, pelos actores e pelos processos usados pelo encenador" (Vilaça, 1966, p.277). Por outro lado, é possível reconhecer a linha brechtiana no próprio texto dramático - haja vista, por exemplo, a dramaturgia portuguesa que aqui nos propomos analisar. Com efeito, é preciso lembrar que as referidas peças portuguesas foram escritas em um determinado contexto em que se privilegiou a construção textual, pois em tempos de ditadura os autores não sabiam se suas peças seriam levadas à cena. Há características específicas de cada uma dessas peças, como veremos, que evidenciam, na dramaturgia portuguesa, um registro das marcas brechtianas de teatro épico, seja pelas indicações cênicas detalhadas, como ocorre em Felizmente há luar!, seja pela composição fundamentalmente narrativa do texto, como ocorre em $\mathrm{O}$ render dos heróis. A propósito, cumpre citar um exemplo, apenas um, de uma didascália, referente à representação do ator, na peça Felizmente há luar!:

Ao dizer isto, a personagem está quase de costas para os espectadores. Esta posiçãoé deliberada. Pretende-se criar desde já, no público, a consciência de que ninguém, no decorrer desta peça, vai esboçar um gesto para o cativar ou para acamaradar com ele. (Sttau Monteiro, 1980, p.14)

seja mais importante que o espectador, por isso devemos pensar no "método" Brecht. 
A análise das fábulas históricas $O$ render dos heróis e Felizmente há luar!, distanciada no tempo e no espaço, é certamente facilitada pela riqueza de detalhes que os textos das referidas obras apresentam. Assim, a nossa leitura dessas peças faz-se tão-somente por meio do texto dramático e, nessa perspectiva, pretende-se afirmar a característica inegável de teatro para ser lido que elas, quase que obrigatoriamente, apresentam devido ao contexto político ditatorial - e, portanto, repressivo - no qual se inserem.

\section{Modos de teatralização}

Além de propor que o ator mostre ao público que está a representar, Brecht utiliza uma série de recursos técnicos que convergem para o mesmo propósito, de modo que "O teatro [épico] teatraliza-se. É disfarce, é fingimento, é jogo" (Vilaça, 1966, p.266). Brecht teatraliza o próprio teatro principalmente por meio do ator, como vimos. Além disso, teatraliza a literatura por meio das narrações e "literariza" a cena ao sugerir a utilização, no palco, de frases escritas em cartazes ou projetadas em tela (Rosenfeld, 2006). Esse processo de teatralização no palco tem certamente por objetivo provocar um olhar reflexivo e distanciado do espectador; é esta, pois, a proposta.

Sendo assim, a inserção de canções (os songs), as formas de narração, a presença de coros, a composição do cenário, que pode ser apenas sugerida e deve estar a serviço da cena, a utilização de recursos gráficos, como cartazes, por exemplo, as projeções de filmes, ${ }^{15}$ são alguns dos exemplos citados por

15 É sabido que essas técnicas, na verdade, foram introduzidas no teatro por Erwin Piscator. É Brecht (1967, p.127) quem explica que, a fim de "dominar pela representação cênica os grandes problemas contemporâneos: luta pelo petróleo, guerra, revolução, justiça, questão racial etc.", surge a necessidade de se fazer uma transformação no 
Brecht. Quando esses recursos são utilizados, o resultado é a composição da cena provida de quebra, como explica Willett (1967, p.220):

As canções e legendas apresentavam-se, indistintamente, como meios deliberados de interrupção da peça, de retirar o vento às velas enfunadas dos atores e de mostrar o verdadeiro mecanismo da obra. Músicos visíveis, luzes visíveis, tinham de ser acompanhados por uma quebra deliberada da tensão e desapontamento do ator.

Mais que provocar uma apreciação estética, o uso, por exemplo, de recursos cênico-musicais surge para aguçar a reflexão do público. A assimilação da música pelo teatro épico brechtiano, ${ }^{16}$ além de estar vinculada ao trabalho do ator - que assume também a tarefa de cantar -, constitui um modo de teatralização. Nas "Notas sobre A ópera de três vinténs", o dramaturgo explica: "o ator não só precisa cantar, como também mostrar ao público que está cantando" (Brecht, 2005, p.42), e os músicos estão igualmente à mostra durante o desempenho do ator que canta, ou seja, a orquestra está o tempo todo no palco. Novamente, na encenação épica, vemos a importância do ato de tudo mos-

palco. Piscator recorre a invenções e inovações, como, por exemplo, a utilização do filme, a reprodução de estatísticas, a inserção de slogans. Assim "o teatro ambicionava colocar seu parlamento (o público) em condição de tomar decisões", e, conclui o dramaturgo alemão, "o ponto de vista estético estava inteiramente subordinado ao ponto de vista político" (idem, p.128).

16 A obra dramática de Bertolt Brecht está toda ela vinculada à música, os chamados songs. O dramaturgo conseguiu realizar muitas das suas aspirações musicais a partir das parcerias com os compositores Edmund Meisel, Kurt Weill, Hanns Eisler, Paul Dessau, Rudolf Wagner-Regeny. John Willett (1967) traça um histórico da relação de Brecht e seu teatro com a música, menciona a parceria do dramaturgo com os compositores citados e comenta algumas das peças musicais compostas para a obra dramática do dramaturgo alemão. 
trar; podemos dizer que se trata, pois, do gesto ostensivo da demonstração.

Para Brecht, a música de Hanns Eisler para as cenas de Vida de Galileu é um exemplo, pois "revela como a plebe deu às teorias astronômicas do sábio um novo teor revolucionário" (idem, p.163). Assim, a música também tem como propósito adotar uma atitude em relação aos acontecimentos narrados, podendo se manifestar de várias formas, desde que mantenha sua independência. A música tem a intenção da provocação e da denúncia, confere ao atorcantor a possibilidade da representação de gestos essenciais e ao espectador a oportunidade de análise crítica. Assim, ao assumir um posicionamento político e adotar uma atitude em relação aos temas, a música, ao mesmo tempo, elimina qualquer encantamento por parte do público e permite ao espectador a reflexão. Por isso, na execução da canção pelo ator também está contido o gesto social:

Identicamente [à música, em Vida de Galileu] em O círculo de giz caucasiano, o modo frio e indiferente com que o cantor canta, ao descrever o salvamento da criança pela criada, apresentado no palco sob a forma de pantomima, põe a nu todo o horror de uma época em que a maternidade pode transformarse em fraqueza suicida. (ibidem, )

Anatol Rosenfeld (2006, p.160, grifo do autor) observa que as canções podem ser dirigidas diretamente ao público - um dos recursos mais importantes do distanciamento - ou a outras personagens e "seu gestus é, quase sempre, demonstrativo, apontando com o dedo as falhas do mundo narrado". As canções, por não apresentarem relação direta com a ação, assumem assim a função de interromper a sequência cênica.

As recomendações que podemos extrair do trabalho de Brecht para a composição da encenação épica têm muito 
a ver com a atividade cenográfica defendida por ele. Não se trata de uma mudança de cenário - não desaparece totalmente, nas suas peças, o palco italiano, de maneira que, dessa perspectiva, ele não estaria fazendo nada de novo, pois na história da cenografia muito já se fez fora do palco italiano -, o espaço é o mesmo - "o espaço é o mundo", explica Bornheim (1992) -, o que ocorre é uma modificação na maneira de utilização desse espaço. Brecht sugere a utilização de esteiras rolantes no lugar do chão, projeções em tela de cinema no fundo do palco, transformação do teto, uso do espaço da plateia como espaço de atuação. O ambiente cênico, por abarcar essa profusão de elementos, transforma-se em espaço de movimento. Com isso, a ideia é a de tornar o espaço cênico mais flexível, tarefa delegada ao que Brecht chamou de "construtor de cena". ${ }^{17}$

Um dos grandes colaboradores de Brecht foi o cenógrafo Caspar Neher, por quem o dramaturgo nutria grande respeito e admiração e cujo trabalho considerava uma verdadeira obra de arte. Os registros de Brecht sobre o trabalho de Neher apontam para determinados recursos utilizados pelo cenógrafo que ajudam a compreender a composição do espaço cênico defendida pelo dramaturgo. Segundo Brecht (2005, p.243), Neher fazia, antecipadamente, esboços e desenhos de seus arranjos cênicos, que eram sempre compostos em pleno acordo com o que pretendia a peça:

E não há, no seu cenário, edifício, corte, oficina ou jardim que não denotem também a marca dos homens que os habita-

17 A ideia de cenógrafo é redimensionada pela introdução do "construtor de cena" - Bühnenbauer -, cujo trabalho, como sempre, não deve propiciar na cena o efeito de ilusão (Bornheim, 1992). Cabe também ao construtor de cena - em conjunto com o diretor, o dramaturgo, o músico e o ator - manter na associação das artes a individualidade de cada uma delas. Nesse sentido, Brecht procura pôr em prática sua negação do conceito wagneriano de obra de arte total. 
ram ou que os construíram. Não só a aptidão e o conhecimento do ofício dos construtores, como também os hábitos dos habitantes, se tornam, desta forma, patentes a todos.

A ideia de arranjo cênico é a de que o cenário apresente condições para incorporar elementos narrativos, já que o palco do teatro épico tem como principal característica narrar os acontecimentos. Como se sabe, no teatro a narração é o recurso que elimina a quarta parede e também põe à mostra a construção teatral. Se o ator se mostra como tal, o palco faz o mesmo: avisa o tempo todo que se trata de teatro, ou seja, não cede de forma alguma ao ilusionismo cênico. Assim, uma mudança de cenário, por exemplo, pode ocorrer à vista dos espectadores e pode ser executada pelos próprios atores; a orquestra, como já referimos, permanece o tempo inteiro presente no palco e não em outro lugar, distante da encenação; as fontes de luz também ficam à mostra. $\mathrm{O}$ ambiente cênico se apresenta, pois, em constante movimentação, de modo a possibilitar uma detida atenção do espectador.

Entre os recursos apontados por Brecht, para que o palco seja um espaço da narração, estão as projeções e os títulos nas cenas. Esses elementos realçam o ambiente dos homens e contribuem para a exata compreensão dos acontecimentos.

Como exemplo de cena épica, o dramaturgo descreve a importância da projeção em $A$ mãe que teve cenário de Caspar Neher:

Numa grande tela de fundo, projetavam-se textos e documentos fotográficos que permaneciam durante as cenas, de forma que a projeção adquiria um caráter de bastidor. A cena indicava, assim, não só um espaço real (por meio de alusões), mas também (por meio de textos e documentos fotográficos) o vasto movimento ideológico em que decorriam os acontecimentos. Em caso algum, as projeções são um simples expediente mecânico, um complemento; não constituem "ardis", 
não significam um auxílio para o espectador, antes lhe são antagônicas, pois fazem gorar todo e qualquer impulso de empatia e interrompem o seu mecânico deixar-se levar. São, por conseguinte, elementos orgânicos da obra de arte que tornam o seu efeito mediato. (idem, p.48, grifo do autor)

As projeções de textos em tela formalizam a comunicação direta com o público, exigindo do ator uma nova postura, uma outra forma de atuação. No momento em que tal recurso é utilizado, a ação é submetida a uma crítica que advém do distanciamento que a cena, em seu conjunto, possibilita.

O mesmo efeito provocado pelo uso de projeções ocorre quando da utilização de títulos nas cenas, que no palco podem aparecer também projetados em tela ou simplesmente escritos em cartazes e letreiros. Os títulos narrativos aparecem para enquadrar uma cena ou intitular uma canção e também assinalam e registram a cronologia da história maior. Podem ainda ser mediadores entre a história maior e a história da experiência individual ${ }^{18}$ (Jameson, 1999); nesse sentido os títulos acatam "outra recomendação típica de Brecht, a de contar a história da experiência individual como nos livros de história" (idem, p.71). Para Brecht (2005, p.160), a peça apresenta uma estrutura própria: a de "uma pequena peça dentro da peça”, na qual devemos contrapor as diversas partes constituintes da fábula. Para chegar a isso, a melhor maneira é a utilização de títulos, que

devem conter flechas certeiras, dentro de uma perspectiva social, e explicitar, simultaneamente, algo acerca da forma de representação desejável, isto é, devem imitar, consoante o

18 Em Mãe Coragem e seus filhos, por exemplo, a história maior é a Guerra dos Trinta Anos e a história menor refere-se aos destinos a que Mãe Coragem e seus filhos estão condenados (Jameson, 1999). Simplificando, a história maior é a dos "livros de história" e a menor é a da experiência individual. 
caso, o estilo do título de uma crônica, de uma balada, de um jornal ou de um quadro de costumes. O tipo de representação a que os usos e os costumes são comumente submetidos suscita facilmente o efeito de distanciamento.

Os títulos e projeções de textos conferem à encenação um caráter literário e, embora estejam incorporados à cena, não pertencem diretamente à ação nem a ela se contrapõem, possibilitando uma visão estática da situação, uma vez que esses textos representam uma oposição ao movimento da ação; éo contraste que provoca a distância necessária à crítica.

Barthes (1999, p.130) ressalta que Brecht "nos propõe não somente uma obra, mas também um sistema, forte, coerente, estável, difícil de aplicar", e sabemos que tal sistema ou método corre o risco de ser banalmente simplificado, pois, como adverte Mário Vilaça (1966, p.268), "a simples utilização da técnica épica não prova que o encenador consiga atingir os fins a que o teatro épico se propõe" - isso, aliás, vale tanto para a encenação quanto para a dramaturgia.

Por enquanto, podemos afirmar que a peça de José Cardoso Pires e a de Sttau Monteiro, que analisaremos a seguir, revelam marcas do teatro brechtiano, pois não perdem de vista o contexto sociopolítico em que foram escritas, estando, portanto, a narrar, de forma alegórica, os acontecimentos da realidade. Quer-se dizer com isso que são peças cuja qualidade estética é sustentada pelas ideias de teatro de Brecht e por isso e além disso representam uma dramaturgia que resistiu às mais graves adversidades.

\section{A fábula brechtiana}

É marcante a importância que o dramaturgo alemão dá à fábula, tal como o filósofo grego que ele, Brecht, em outros assuntos contesta: 
Quanto ao estilo de representação, concordamos com Aristóteles quanto a considerar a fábula o cerne da tragédia, mas discordamos dele no que respeita ao objetivo a que deve obedecer a sua representação. A fábula não deve ser um mero ponto de partida para toda espécie de digressões no domínio da psicologia ou em qualquer outro; deve, sim, conter tudo em si, e tudo deve ser feito em função dela; basta narrá-la para que todos os acontecimentos nela contidos se efetivem. (Brecht, 2005, p.212)

Do conceito de fábula na obra teatral, podemos depreender, segundo Pavis (2007, p.157), duas concepções: "como material anterior à composição da peça e como estrutura narrativa da história" - nesta segunda concepção, a fábula seleciona os episódios das cenas e textualiza ações que ocorreram fora da peça.

A fábula, no sentido brechtiano, não é simplesmente o enredo da peça - extraído da vida tal como poderia ser na realidade -, mas a concepção que o autor tem da sociedade na qual ele vive. A fábula épica brechtiana desvela as contradições do mundo dos homens sem mascarar a incoerência dos acontecimentos narrados, nem esconder a ilogicidade desses acontecimentos. Por isso mesmo, ela se estrutura na falta de continuidade da ação, frequentemente interrompida pela canção, pelo ator que fala diretamente ao público etc. Para Brecht (2005, p.159): “Tudo depende da fábula, queé o cerne da obra teatral. São os acontecimentos que ocorrem entre os homens que constituem para o homem matéria de discussão e crítica, e que podem ser por ele modificados".

A fábula brechtiana apresenta acontecimentos isolados, mas de certa forma interligados e com funções claras, constituindo uma estrutura própria, qual seja, "a de uma pequena peça dentro da peça” - daí a inserção de títulos. A justaposição de cenas aparentemente soltas (Magaldi, 2001) constitui a estrutura utilizada por Brecht em sua dramaturgia, principalmente na fase de maturidade do dramaturgo 
(Mãe Coragem e seus filhos, O círculo de giz caucasiano, Vida de Galileu).

No que se refere aos temas, a fábula do teatro épico aprofunda-se nos problemas sociais. Barthes (1999, p.1301) assinala a convergência entre o pensamento brechtiano e os grandes temas de "nossa" época, a saber:

que os males dos homens estão entre as mãos dos próprios homens, isto é, que o mundo é manejável; que a arte pode e deve intervir na história; que ela deve hoje concorrer para as mesmas tarefas que as ciências, das quais ela é solidária; que precisamos de agora em diante de uma arte de explicação, e não mais somente de uma arte de expressão; que o teatro deve ajudar resolutamente a história desvendando seu processo; que as técnicas cênicas são elas próprias engajadas; que, afinal, não existe uma "essência" da arte eterna, mas que cada sociedade deve inventar a arte que melhor a ajudará no parto de sua libertação.

Compreende-se daí que à fábula brechtiana o que mais importa é a ideia de que o homem é capaz de modificar a história. Por essa razão, talvez, a dramaturgia brechtiana apresente tantos episódios em que o julgamento, o tribunal ( $O$ círculo de giz caucasiano, Vida de Galileu, A alma boa de Setsuan e até Aquele que diz sim, aquele que diz não) aparecem como forma de se fazer compreender didaticamente essa relação mutável que o homem precisa estabelecer com o processo histórico. Para Brecht, o importante não é julgar, mas compreender, como esclarece Touchard (1970), compreender não o homem, mas "o mecanismo humano em seu entrosamento social”; por isso é tão essencial mostrar, narrar, explicar os acontecimentos para que se dê essa compreensão.

Na fábula brechtiana instaura-se a estrutura aberta, ou seja, "que começa com a narrativa e continua com ela por várias cenas” (Bentley, 1991, p.304), sendo que no lugar de 
desfecho há um questionamento, um final inconcluso. Com isso, a personagem épica parece se perpetuar para além da dimensão do palco (Roubine, 2003), istoé, não "morre" real ou metaforicamente no fim da peça, como acontece na tragédia. O exemplo maior de supressão de desfecho conclusivo na obra dramática de Brecht encontra-se em A alma boa de Setsuan, peça em que as últimas palavras de um dos atores que vêm à ribalta apresentar suas desculpas, à guisa de epílogo, falando diretamente ao público, são as seguintes:

Para esse horrível impasse, a solução no momento Talvez fosse vocês mesmos darem trato ao pensamento Até descobrir-se um jeito pelo qual pudesse a gente Ajudar uma alma boa a acabar decentemente...

Prezado público, vamos: busque sem esmorecer!

Deve haver uma saída: precisa haver, tem de haver! (Brecht, 1992, p.185)

De acordo com Walter Benjamin (1987), como o teatro épico procura excluir da cena o "sensacionalismo temático", é preferível à dramaturgia uma fábula antiga a uma fábula nova, de modo que os acontecimentos narrados sejam já conhecidos do público - por isso os temas históricos são os mais apropriados.

Desta perspectiva, José Cardoso Pires e Luís de Sttau Monteiro de fato seguiram a lição de Brecht ao elegerem para suas peças episódios históricos bem conhecidos do público português, como a Revolução de Maria da Fonte e a trajetória do General Gomes Freire - daí serem elas denominadas fábulas históricas. 


\section{3 \\ O RENDER DOS HERÓIS, A FÁBULA histórica de CARDOSO PIRES}

São duas mulheres, uma empunhando a pá do forno, outra a roçadoura na ponta de um longo varapau. Mas a paisagem sinistra, o pavor, o que quiserem, agigantam estas armas a ponto de lhes darem proporções de símbolos, grandes e esguios como lanças de guerreiros. (Cardoso Pires, 1970, p.11-2)

Considerada pela crítica a primeira peça da dramaturgia portuguesa de inspiração brechtiana, O render dos heróis (1960), de José Cardoso Pires (1925-1998), apresenta como matéria histórica a revolta popular conhecida como Maria da Fonte, ocorrida em 1846. A origem da revolta esteve ligada ao descontentamento dos camponeses minhotos com as reformas no sistema tributário e principalmente com a proibição da realização de enterros dentro das igrejas, pois "[...] enterrar cristãos em covas, no descampado, aparecia como uma ofensa sacrílega e um atentado à dignidade humana: era tratar pessoas como se fossem animais" (Saraiva, 1988, p.303). O nome "Maria da Fonte" se deve ao fato de 
um grande número de mulheres ter participado da revolta, tendo os primeiros incidentes ocorrido na freguesia de Fonte Arcada, em Póvoa de Lanhoso (Minho). Comoeram muitas as mulheres que tomaram parte dos motins iniciais, não se sabe a real identidade de Maria da Fonte. A esse respeito, Oliveira Martins (1895, p.194) comenta que "O herói da revolução minhota devia ser uma mulher; não um homem; devia ser desconhecido, lendário: antes um nome do que uma pessoa verdadeira".

De acordo com Oliveira Marques (1998), historicamente, a Revolução da Maria da Fonte teve duas fases: a primeira foi deflagrada pela revolta popular, com duração de apenas um mês (abril-maio de 1846), tendo como resultado a demissão de António Bernardo da Costa Cabral ${ }^{1}$ do Governo; a segunda, chamada Patuleia, bem mais longa e configurada como guerra civil, teve duração de oito meses (outubro de 1846 a junho de 1847), sendo finalizada com a intervenção estrangeira - apoiada pelo governo de Lisboa. O fim da revolta trouxe como consequência o regresso dos Cabrais.

As tensões sociais e as mudanças no contexto político provocadas pela revolta popular constituem o enredo da peça, o qual abrange, no prólogo, a narração dos primeiros motins dos revoltosos; depois, nas três partes seguintes, a propagação da revolta e as consequências políticas e sociais

1 António Bernardo da Costa Cabral, nomeado ministro do Reino pela Rainha em 1842, era o verdadeiro dirigente do Governo, presidido pelo Duque da Terceira. Costa Cabral foi um estadista autoritário e o seu governo "estabeleceu no País um regime de repressão e de violência, embora a imprensa continuasse livre” (Oliveira Marques, 1998, p.40). Segundo Oliveira Martins (1895, p.268), depois da Maria da Fonte e da Patuleia, "Costa-Cabral - o conde de Thomar: era mais que um homem: era um systema e um phantasma”. António Bernardo da Costa Cabral era apoiado por seu irmão, José Bernardo da Silva Cabral, por isso a designação popular de governo dos Cabrais ou Cabralismo. 
do movimento; no epílogo, a interferência estrangeira - de espanhóis e de ingleses -, juntamente com o retorno dos Cabrais figurado na "apoteose grotesca".

A cena de abertura narra o que seria a primeira ação da revolta. Um grupo de mulheres, "esta com filho no colo, aquela arrastando uma cabra”, avança à frente do palco, "atrás delas vêm camponeses de podoa no cinto e arma à bandoleira", até que se ouve um toque de cornetim cada vez mais forte, fazendo-os saltar em fuga desvairada:

$\mathrm{Na}$ noite de quinze para dezesseis de abril um povo dos confins do Alto Minho deixou casas, deixou tudo, e espalhou-se pela serrania bárbara. Fazia luar, um luar negro, se assim se pode dizer. Cá em baixo tudo escuro e torvo: carvalhos velhos, torcidos, carvalhos dos tempos do Dilúvio, urzes e medronheiros pelados e cobertos por uma espécie de ferrugem da terra que lembrava cinza e mundos devastados. Depois o rolar das águas nas profundezas das brechas; depois os fossos de silvedo, os labirintos dos lobos e as bocarras dos desfiladeiros - tudo tornava a noite medonha e traiçoeira.

Um pano negro, a serrania. E diante do pano negro aparecem-nos as primeiras figuras em debandada [...]. Salta a velha do bordão, foge a outra, desvairada, espanta-se a cabra, e não há quem não procure uma saída [...]. (Conta-se que certa mocinha, na ânsia do desespero, se quis lançar a um barranco - isto é: do palco para baixo - e que a muito custo foi salva por aquela multidão tresnoitada que, bem ou mal, sempre conseguiu escapar à ameaça do feroz cornetim). (Cardoso Pires, 1970, p.11-3)

Se não fossem as duas referências ao cenário - "Um pano negro, a serrania" e "do palco para baixo" -, esse texto poderia ser o início de um romance ou conto. Essas duas referências indicam, entretanto, que estamos diante de texto teatral e, ao mesmo tempo, mostram a construção 
da cena ${ }^{2}$ no palco, avisando ao público tratar-se de espaço fictício e, por extensão, de obra de ficção. A caracterização dessa cena de abertura condiz com uma possível função atual do prólogo, que "se presta ao jogo das apresentações que quebram a ilusão e a modalização das narrativas 'encaixadas"” (Pavis, 2007, p.309). Assim, no caso da encenação de O render dos heróis, o prólogo constitui certamente texto de um narrador, apesar de não haver nenhuma indicação na peça de como esse prólogo deve ser de fato encenado. Da mesma forma que o prólogo, todos os outros textos de mesmo caráter narrativo que aparecem geralmente no início de cada parte ou de cada cena podem ser narrados, na encenação, por uma personagem qualquer que assume o papel de narrador.

Nos quadros cênicos seguintes ao prólogo vemos o coronel Inocêncio Matamundos e o sargento Sargentanas em plenos poderes na aldeia do Vilar - onde decorre a maior parte das ações -, na atividade de arrolamento dos bens confiscados e registro de prisão de pessoas que se negaram a pagar os impostos devidos ou a receber à tropa em suas casas. O coronel Matamundos quer saber, por todos e quaisquer meios, a identidade dos "cabeças da revolta" e que tipo de armas usavam. Pela boca das Comadres sabemos que Sargentanas, pressionado por seu superior, coronel Matamundos, e na autoridade de algoz que lhe é atribuída, tortura a velha Maria Henriques - presa por cantar trovas políticas -, a fim de que ela se confesse líder dos motins. Enquanto isso, guerrilheiros encabeçados pelo bacharel Alexandre,

2 Assim também acontece no "antecapítulo" do romance O Delfim, de Cardoso Pires, em que o narrador-autor-personagem nos dá pistas das suas referências para a escrita do romance - anotações de suas conversas com Manuel Palma Bravo e consulta à Monografia do Termo da Gafeira. Se em O Delfim o leitor é convidado a adentrar nos "bastidores da ficção", ao espectador da peça é descortinado o espaço do teatro. 
acampados nas serranias vizinhas, planejam tomar o Vilar. Eles têm o apoio de Maria Ricarda-filha do desembargador Dr. Silveira, um oponente da revolta popular. O ingresso de Maria Ricarda ao grupo de guerrilheiros se deve ao fato de ela ser noiva de um dos revoltosos, o Acadêmico, que anda com seus homens a se bater contra as tropas de Matamundos. Do lado dos guerrilheiros está também o miguelista padre Casimiro, que se dirige ao público e se apresenta como "padre-soldado na militança da justiça". O movimento de revolta cresce cada vez mais e várias aldeias se levantam pela Maria da Fonte.

Percorrendo quase todas as cenas, além das Duas Comadres, está o Cego. Essas três personagens são os principais comentadores e, por vezes, narradores dos acontecimentos. O Cego, personagem essencialmente épica, frequentemente interrompe a sequência cênica com cantos e poemas e se revela Falso Cego na segunda parte da peça: "Tanto vi no mundo que me cansei. Tive que me fazer de cego se quis comer as migalhas dos ricos" (Cardoso Pires, 1970, p.105), diz ele às Comadres, insinuando assim que com a propagação da revolução ele poderia, finalmente, deixar de se fingir de cego.

Um acontecimento ocorrido fora de cena insere na peça um momento de tensão dramática. Trata-se do assassinato do noivo de Maria Ricarda, o Acadêmico. A notícia chega à tropa de Alexandre, no Vilar, deixando Maria Ricarda transtornada a ponto de ela escrever uma carta ao pai, Dr. Silveira, insinuando que cometerá suicídio - mas isso de fato não acontece, como verificamos na primeira cena da terceira parte.

A peça não apresenta linearidade dos fatos, e sim quadros de episódios que narram os acontecimentos. Os diálogos, na verdade, também se propõem a contar e as cenas a descrever e a narrar situações. Na primeira cena da terceira parte, enquanto a baronesa de Stanley, Dr. Silveira 
e Maria Ricarda conversam, um criado entra e substitui o quadro que figura a rainha D. Maria II pela pintura a óleo que representa a cena de São Jorge matando o dragão. A substituição do quadro sugere a fragilidade e o enfraquecimento do poder da rainha devido às revoltas populares que se propagam pelo país.

Depois de decorrido um tempo de aproximadamente três meses de revolta, uma Junta é formada por Dr. Silveira, padre Casimiro, bacharel Alexandre e cavalheiro Stanley para um acordo de pacificação do reino. Há, no entanto, divergências entre eles: Alexandre quer que se garanta o direito dos populares para convencê-los a largar as armas; padre Casimiro vê com desconfiança o novo governo de coligação nomeado pela rainha e se recusa a desarmar seus homens; Silveira e Stanley se aproveitam do movimento popular para salvaguardarem seus interesses próprios de manutenção do poder. Com medo de ser desprezado "por amigos e inimigos, ou seja, ignorado pelo povo e pelos próprios cabralistas", Stanley tem uma ideia fixa: prender Maria da Fonte, quem quer que seja ela, a fim de enfraquecer o partido dos revoltosos. Além do oportunista Dr. Silveira, Stanley consegue levar para o seu partido o padre Casimiro, a quem apresenta Macdonell - segundo Stanley, Macdonell é um representante de D. Miguel, encarregado de nomear o padre "capelão-mor dos exércitos de terra e mar”. Comovido com a nomeação e se deixando levar pela vaidade, o padre Casemiro passa a tomar parte nos piqueniques regados a champanhe e vinho promovidos pelo glutão Macdonell, pelo Dr. Silveira e por Stanley. Nesses encontros eles tramam a prisão de Maria da Fonte, sem nem saber ao certo quem seria ela.

O grupo de Macdonell busca uma mulher qualquer para ser "desmascarada" a Maria da Fonte. Como a velha Maria Henriques acaba por ser morta em decorrência das torturas de Sargentanas, e como Maria Ricarda, apesar de 
ter feito parte da guerrilha, é filha do Dr. Silveira, resta, então, a Maria Angelina. Para os propósitos do grupo de Macdonell, Angelina apresenta as condições ideais, pois se encontra presa na cadeia de Póvoa do Lenhoso, acusada de incendiária, resistência ao fisco, mancebias... Mas os revoltosos invadem a cadeia e a libertam, para desespero de Macdonell, que sai às ruas com seus partidários em busca de uma mulher, qualquer uma, que possa ser apontada como a Maria da Fonte: "Ele [Macdonell] e os do grupo deitam uns tais olhos às camponesas, olhos de quem estuda e escolhe, seguem-nas com tanta atenção que elas, desfilando, voltamse para trás, desconfiadas" (idem, p.229).

Os guerrilheiros, mais uma vez chefiados pelo bacharel Alexandre, tornam a se impor e se reúnem noVilar em marcha de despedida, pois pretendem seguir para Lisboa a fim de fortalecer a revolução. De repente, a Marcha da Maria da Fonte é interrompida pela invasão de tiros e gritos. O Falso Cego percebe imediatamente o que está por vir e volta a se fazer novamente de cego. O Almirante Inglês e o General Espanhol - representantes da intervenção estrangeira, consentida pelo governo português - entram e abrem alas para o cortejo da volta de Costa Cabral, que vem vestido de bode sobre um andor, encerrando assim a peça com a chamada apoteose grotesca.

Cardoso Pires utiliza os recursos propostos por Brecht para a construção de $O$ render dos heróis. Além de narrativa, a peça apresenta títulos, cartazes, palco quase desprovido de cenário, entre outros elementos, como veremos a seguir.

\section{Recursos épico-brechtianos}

Cardoso Pires segue a convenção de escrita de texto teatral com as rubricas destacadas em itálico, mas também introduz, iniciando cenas ou partes da peça, uma série de 
textos narrativos que se sobrepõem em importância aos diálogos das personagens. É, pois, na narração que a peça de Cardoso Pires se estrutura fundamentalmente, já que toda ela é marcada por esses textos narrativos:

\section{Temos outra vez as Duas Comadres.}

Sempre pegadas uma à outra, fazem um par muito especial. Quando menos se espera aparecem. Agora aqui, amanhã acolá, ora a rondarem um povoado qualquer, ora formigando de ponta a ponta dessa serra, por cima de toda a folha.

Pode o mundo girar num torvelinho, pode Lisboa trocar, como troca, mil e um governos de entrudo, que aquelas almas limitam-se a abanar a cabeça e lá vão com o pesado fole - a sua cruz, como diriam depois. Para elas, certa como a luz do meiodia, só uma coisa: o destino de uma Maria Angelina a que o povo chama "a da Fonte". E o resultado está à vista: duas velhas carregando um fole de pólvora. (Cardoso Pires, 1970, p.201)

O caráter narrativo dessa e de outras passagens desse tipo "literarizam" a cena, revelando uma clara aproximação da peça às técnicas do teatro épico propostas por Brecht. $\mathrm{Na}$ encenação épica esses textos narrativos poderão constituir a fala de um ator que "sai" do seu papel de personagem para assumir a função de "narrador”. Duarte Ivo Cruz (2001, p.307) chama essas narrações da peça de Cardoso Pires de "textos de ligação", e explica:

O render dos heróis recria a "Maria da Fonte" e dá-lhe a dimensão épica do movimento popular, que aliás foi. Notase o romancista no detalhe e na limpidez das notas de cena e dos textos de ligação, que devem constituir, na dinâmica do espetáculo, as falas do narrador.

Considerados como parte da encenação - na voz de um narrador ou por meio de um outro recurso com a mesma função, como, por exemplo, a projeção em tela -, esses tex- 
tos de ligação conferem ao espetáculo um caráter literário, comentando a ação e produzindo, deste modo, o efeito de distanciamento brechtiano.

No que se refere ao cenário, $O$ render dos heróis apresenta um principal objeto cênico que é o "pano negro", frequentemente manuseado pelas diferentes personagens à vista de todos: "Sargentanas abre o pano da noite e perfila-se: está apresentada a povoação do Vilar, resumida a um largo do cruzeiro" (idem, p.17). No palco, o elemento cênico que separa a aldeia do Vilar - que se limita à praça ou largo, com um cruzeiro à esquerda e a casa do cura à direita - das vizinhanças e da serrania é um pano negro, objeto metafórico que ora desvenda, ora oculta as ações das personagens. Sargentanas, ao abrir o pano negro, revela a aldeia do Vilar, tomada pelo "reino" do coronel Matamundos que ali manda e desmanda. Cavalheiro Stanley, com o gesto de abrir e fechar o pano negro, revela e oculta o espaço da cena de piquenique onde ele e seus homens confabulam e tramam. Costa Cabral faz "correr o pano sobre o choro de uma criança” e encerra a peça. $\mathrm{O}$ pano negro cumpre, portanto, dupla função: uma, digamos, cenográfica, que define a orientação épica da encenação; outra metafórica, que mostra ou oculta os bastidores do Poder, representado pelas personagens dos exemplos citados. Assim, a aldeia do Vilar, desvendada e ocultada pelo pano negro, concentra em si direta ou indiretamente a representação do espaço onde se institui o Poder e tudo o que ele significa. Da mesma forma que o microcosmo fictício da Gafeira, espaço criado por Cardoso Pires em O Delfim, quer representar o macrocosmo português, como assinala Ana Paula Arnaut (2002) na análise que faz desse romance, assim também a aldeia do Vilar, microcosmo fictício, representa Portugal:

Vilar à letra quer dizer "povoado", pouco mais que um lugarejo. Embora crescido, com regedor, igreja e padre-mestre, juridicamente aldeia, Vilar é um desses lugares abstractos e 
esquecidos do mundo. Não tem correio regular, ao menos de semana a semana, nem largo de feira. Tem um terreiro acanhado, com o competente cruzeiro, onde fazem alto as pobres procissões esfiapadas que, no correr do ano, vão cumprindo o calendário da diocese.

Estamosa vera Praça: pequenae desnudada; um cruzeiroàesquerda, casa do cura à direita. Edisse. (Cardoso Pires, 1970, p.16)

Énesselugar "abstracto" e "esquecido no mundo" que os governantes oprimem o povo; é, pois, noVilar que se instaura a força do Poder representado inicialmente por Matamundos e seus homens, depois pelo retorno dos Cabrais.

No que diz respeito à estrutura da peça, Cardoso Pires insere títulos, legendas e letreiros, assim como canções, coros e recitações - recursos épico-brechtianos que têm como função interromper o fluxo da ação.

Cada uma das três partes da peça é introduzida por um título explicativo - por exemplo, este entre o prólogo e a primeira parte: "Que se passa entre 28 e 30 de abril, nesse mesmo povoado donde partiram os fugitivos e que chamaremos do Vilar e nalgumas serranias não muito longe dali"-, marcando assim uma cronologia histórica, embora as cenas sejam episódicas, pois Cardoso Pires "constrói a múltipla sincronia da temporalidade presente utilizando cortes e elipses entre cenas" (Werneck, 2005, p.226).

Os títulos, no momento em que são inseridos, representam um elemento estático que não pertence diretamente à ação e por isso dela se distancia. Não havendo no texto uma indicação precisa para o aproveitamento desse recurso na encenação, fica em aberto - ou a cargo do encenador - o modo como os títulos serão apresentados no palco.

Um último recurso épico que aqui apontamos é a utilização da canção em $O$ render dos heróis. ${ }^{3}$ Maria Henriques e

3 Hélder Costa (1965, p.231) nos dá um relato sobre a composição 
o Falso Cego são as principais personagens responsáveis por introduzir nas cenas canções cujas letras, geralmente satíricas, apresentam crítica direta ou indireta à situação política:

"Xácara da visita à rainha"

Aprende, Rainha, aprende

Mede agora o teu poder,

Tu dum lado o povo doutro

Qual dos dois há-de vencer.

Se tens armas, não nos temas

Se as não tens, vai procurá-las

Ao brasão dos maus Cabrais

Que tens nele três punhais.

(Cardoso Pires, 1970, p.239)

Com exceção do Falso Cego, as personagens que geralmente se expressam por meio do texto cantado ou recitado são aquelas que de alguma forma estão fragilizadas. Assim, o Soldado-Sentinela de Matamundos canta uma paródia do "Hino da Maria da Fonte" quando Vilar está cercada pelos guerrilheiros; Matamundos canta quando está foragido com Sargentanas pelos campos; os soldados entoam o "Coro dos soldados prisioneiros" - o título do coro já diz tudo; Maria

musical na encenação de $O$ render dos heróis em 1965: "A música foi de Carlos Paredes [...] essa música leve, alegre, popular, não era realmente o que o dramaturgo, encenador e actores queriam dizer? Cremos que sim, e julgamos a colaboração de Carlos Paredes um factor importantíssimo no triunfo conquistado pelo Teatro Moderno de Lisboa".

4 Oliveira Martins (1895, p.179), em seu Portugal contemporâneo, obra que constitui a base histórica para $O$ render dos heróis, cita duas estrofes da "Xácara da visita à rainha", cujos versos não correspondem, no entanto, aos que na peça são cantados pelo Falso Cego. Parece-nos que Cardoso Pires utilizou em sua peça apenas o título da canção citada pelo historiador. 
Ricarda canta quando está de luto e recita quando está presa; Maria Henriques entoa canções "imorais contra as casas da justiça e contra a pessoa dos ministros", no dizer das autoridades, e por isso ela é detida.

Em algumas cenas, a cançãoé interpretada coletivamente: além do "Bendito" - canto religioso - e do "Coro dos soldados prisioneiros", o outro momento é o da execução do "Hino da Maria da Fonte" pela tropa que marcha. Com a chegada dos espanhóis e, em seguida, a entrada do Almirante Inglês, a "'Marcha da Maria da Fonte’ é abafada por toques de clarim e ordens de ataque" e o que se ouve no lugar do hino é uma charanga que toca "O rei chegou", uma referência a Costa Cabral. A intervenção estrangeira - apoiada, como já foi dito, pelo governo português - abafa e reprime a ação coletiva de cantar o hino revolucionário e violentamente elimina qualquer manifestação de oposição ao Poder, pois quando uma "voz perdida" grita "Viva a Maria da Fonte" ouve-se um tiro e o ruído de um corpo que tomba.

Na peça, diferentes funções são atribuídas à utilização da canção, que pode, por exemplo, abrir ou encerrar uma cena, interromper um diálogo, comentar uma situação apresentada. Em todos os casos, a canção sublinha o aspecto narrativo da fábula e suscita o despertar da reflexão crítica por meio do seu conteúdo ou pela forma como se impõe na cena. Segundo a proposta de distanciamento brechtiano, a canção deve ser executada em separado, isto é, destacada, e não se presta simplesmente a um acompanhamento incidental da cena,

[... ela [a canção] se desprende facilmente de dimensões psicológicas, líricas, sentimentais, para assumir um conteúdo objetivo, ligando-se a algo que está acontecendo, ou a um fato, ou a uma tese, ou a uma lição de caráter moral. Por esse caminho, a canção oferece possibilidades didáticas consideráveis. (Bornheim, 1992, p.300) 
Anatol Rosenfeld (2006, p.160) nota que a função da música na estética brechtiana de teatro épico é a de "comentar o texto, de tomar posição em face dele e acrescentar-lhe novos horizontes". Na peça, as canções são dirigidas diretamente ao público ou a outras personagens e ora têm relação direta com a ação, comentando-a, ora não, interrompendo-a.

Dada sua caracterização épica, a peça de Cardoso Pires não concede ao espectador identificar-se com as personagens apresentadas. Os recursos brechtianos que ela adota têm como principais funções colocar à mostra a construção teatral, interromper a sequência cênica e, com isso, quebrar a quarta parede. Os textos narrativos fundamentalmente interrompem os diálogos e comentam situações de modo a despertar o espectador/leitor para a reflexão sobre o que assiste ou lê, tirando-o do "deixar-se levar". Ao espectador de $O$ render dos heróis o mecanismo teatral é inteira e constantemente desvendado pela constituição do cenário, construído ou modificado pelas próprias personagens, desfazendo as possibilidades de efeito de real, lembrando ao público que ele está no teatro.

\section{"Infeliz a terra que precisa de heróis"}

Em $O$ render dos heróis encontramos algumas das personalidades históricas (duque de Palmela, rainha D. Maria II, D. Miguel) que não são exatamente figuradas como personagens presentes na peça, mas são apenas referidas nos diálogos ou aparecem mascaradas e ridicularizadas (António Bernardo da Costa Cabral, José Bernardo da Silva Cabral, duque de Saldanha) na apoteose grotesca. A própria Maria da Fonte - "que nunca ninguém soube ao certo quem teria sido” (Simões, 2004, p.96) - tem a identidade incerta em boa parte da peça, pois há três mulheres que são apontadas pelas outras personagens como sendo 
a que deu nome à revolta popular: Maria Ricarda, Maria Henriques e Maria Angelina.

Com a referência às três Marias da Fonte, Cardoso Pires desfaz ou desmonta a ideia de uma liderança dos primeiros motins da revolução e, ao mesmo tempo, confunde as personagens - e, de certa forma, também o espectador - sobre a identidade de Maria da Fonte. Maria Angelina, Maria Henriques e Maria Ricarda são, pois, "cognomes épicos", assim como os vários nomes pelos quais o narrador do romance $O$ Delfim se refere à personagem Tomás Manuel, como explica o próprio Cardoso Pires (1977, p.165-6):

Identificando o herói por sucessivas designações conferese-lhe um halo paralendário de personagem que simboliza o acontecimento e cria-se uma relação mais crítica do leitor para com a narrativa. As mesmas designações permitem ainda escalonar os tempos de ação (como fez Guimarães Rosa, que foi estoriador de santos e de bandidos sertanejos) ou os alternar e confundir a bel-prazer (como tentou o escritor-furão da Gafeira).

A incerteza das outras personagens, sugerida nas cenas, sobre quem seria a Maria da Fonte alterna-se no decorrer da peça, até que na sétima cena da terceira parte ela é identificada com Maria Angelina. A Maria da Fonte, no entanto, estálonge de ser a personagem central-foco de interessee atenção dos leitores/espectadores - ou a representação do herói mítico, assim como também está ela distante de ser o tema ${ }^{5}$ da peça. O herói mítico, de acordo com Rosenfeld (1996, p.36),

é a personificação de desejos coletivos. Em tempos de crise, esse desejo impregna-se de força virulenta e projeta a imagem

$5 \quad$ Em Felizmente há luar!, de Sttau Monteiro, o general Gomes Freire nunca aparece, mas a trajetória dessa personagem histórica é o tema da peça. 
plástica e individual das esperanças em forma de personificação. Na criação do herói mítico prevalece a crença primitiva de que todos os poderes humanos e naturais podem condensarse numa só personalidade excepcional. Quando em amplos grupos se manifesta a esperança coletiva com intensidade máxima, eles facilmente podem ser convencidos de que só se necessita da vinda do homem providencial para satisfazer todas as aspirações.

Nessa descrição não se encaixa a imagem de Maria Angelina, a da Fonte, pois ela, apesar de fazer parte da guerrilha, não personifica os desejos coletivos; ao contrário, ela está, na realidade, interessada nos papéis que denunciam sua herdade no Brasil. Quando, na cena quatro da segunda parte, ela chega ao Vilar acompanhada pelos guerrilheiros, interpela os soldados e depois o regedor sobre os tais papéis. Assim, ao ser informada de que os documentos foram para a Conservatória da Amoreira, vai imediatamente para lá e resolve seu problema pessoal, incendiando a Conservatória. Trata-se de uma mulher que age com o propósito de resolver um problema pessoal (esconder os documentos que provam sua herança, para não pagar mais impostos ou ter parte de seus bens confiscados; por isso provoca o incêndio no tombo da Amoreira); sua ação é uma reação à imposição que sofre do fisco e não uma ação em prol do coletivo com a anulação do individual. Além disso, a Maria da Fonte pode ser heroína - entendida como personagem central e herói clássico, mítico - no fato histórico, mas não na peça. É nesse sentido que Cardoso Pires exclui a existência de herói ou heróis, apesar do título de sua fábula histórica.

$O$ render dos heróis traz sintetizado no título o que narra a fábula. Nesse quase paradoxo de heróis que são rendidos vemos a revolução completamente reprimida pela aparição das figuras do Poder - ainda que ridicularizadas na apoteose grotesca - que os revoltosos tinham, por algum 
tempo, derrubado. Por isso os versos de Alexandre O' Neill, escolhidos por Cardoso Pires como epígrafe de sua obra, constituem um prenúncio que sublinha e enfatiza o sentido já instaurado no título da peça: "Os heróis são/os heróis vêm/os heróis vão...".

O uso do termo no plural ("heróis") no título da peça traduz um apagamento do indivíduo, já que as personagens ou se definem pelo grupo ao qual pertencem - guerrilhas (bacharel Alexandre, Maria Angelina, Maria Ricarda etc.), tropas (Matamundos, Sargentanas, soldados, Sentinela), junta (cavalheiro Stanley, Dr. Silveira, padre Casimiro, também Alexandre) - ou se duplicam em personalidades semelhantes, como é o caso das Comadres, que são duas, a Primeira e a Segunda, ou em personalidades aparentemente opostas que se alternam, como a do Cego, que se revela Falso Cego e depois cego novamente, um anti-herói que se esconde atrás da falsa cegueira para sobreviver.

Não há como deixar de relacionar o título e a epígrafe, assim como determinadas falas - principalmente do Falso Cego e das Comadres, mas também de outras personagens - às famosas frases da peça Vida de Galileu (escrita entre 1938 e 1939), de Bertolt Brecht: "Infeliz a terra que não tem heróis/Não, infeliz a terra que precisa de heróis".

Em Vida de Galileu, Andrea, assistente de Galileu, espera que o mestre não renegue a doutrina do movimento da Terra em uma sessão da Inquisição: "Andrea gritando Eles não vão ter a coragem! E mesmo se tiverem, ele não vai renegar. 'Quem não sabe a verdade é estúpido e mais nada. Mas quem sabe, e diz que é mentira, esse é um criminoso", (Brecht, 1991, p.150). No entanto, depois de falas eufóricas de Andrea, de Federzoni e do Pequeno Monge, quase certos de que Galileu não renegará a teoria, ouvem-se ecoar o sino de São Marcos e a voz do arauto que lê nas ruas a retratação: "Eu, Galileu Galilei, professor de matemática [...] abjuro o que ensinei: que o Sol seja o centro do mundo, imóvel em 
seu lugar, e que a Terra não seja centro nem imóvel [...]" (idem, p.153). Ao entrar na sala, Galileu ouve Andrea dizer em voz alta: "Infeliz a terra que não tem heróis" e depois os gritos indignados do rapaz, que faz menção de ir embora. Calmo, Galileu pede água e começa a falar: "Não, infeliz a terra que precisa de heróis" (idem, 154).

Abordada pelos teóricos e comentadores, o fato é que o próprio dramaturgo não deixou nenhum registro em que discutisse com profundidade a questão da ausência ou negação da figura do herói. Anatol Rosenfeld (1996, p.48) comenta que nas teorias de Brecht "não tem uma linha no que se refere ao problema do herói”. A afirmação de Rosenfeld é, de certa forma, reiterada por Bornheim (1992, p.241-2), e embora este último afirme que "é sempre dentro da perspectiva da desconstrução que evolui em Brecht a ideia do herói”, admite que o autor alemão "nunca escreveu detidamente sobre esse portentoso assunto". Ao criticar a encenação de Vida de Galileu dirigida por José Celso Martinez Corrêa, apresentada em Portugal em 1975 , o encenador português Mário Sério (1976, p.94) comenta que o Galileu de Brecht é "o anti-herói, o antirresistente e o contrário do culto do super-homem". Concordamos que na obra dramática de Brecht está implícita a negação do herói clássico, mítico e inacessível. Na peça de Cardoso Pires encontramos essa mesma negação do herói mítico, no que se apontaria um fio de diálogo intertextual com a fala do Galileu brechtiano. Como não é nossa intenção e nem propósito fazer aqui um estudo de dramaturgia comparada, apontamos as semelhanças entre as falas do Falso Cego de Cardoso Pires e as de Galileu, com o propósito de analisar seu sentido apenas em $O$ render dos heróis.

Seja nas quadras entoadas pelo Falso Cego, seja nas frases entrecortadas que não constituem um diálogo retilíneo ou contínuo das Comadres, seja nos discursos proferidos pelos representantes do Poder, pela boca de suas personagens, 
Cardoso Pires debate o tema do herói. São diferentes pontos de vista não somente porque são distintas as personagens, mas porque a peça assume a lição de Brecht e estende a reflexão ao público, com a proposta de mostrar ao espectador as várias possibilidades de análise de uma mesma questão, como exige o processo dialético. Por exemplo, o desembargador Dr. Silveira, "cidadão do poder constituído", como ele mesmo se define, em um momento de completa embriaguez declara e pergunta: "E a história todos os dias muda de heróis [...] E hoje? Quem são os heróis de hoje?” (Cardoso Pires, 1970, p.61-2). Sem resposta na cena, a pergunta serve para introduzir o assunto eé ao público que ela indiretamente se dirige. $\mathrm{Na}$ terceira parte da peça, o miguelista cavalheiro Stanley sugere que se desmascare a crendice em Maria da Fonte: "Estamos aqui para destruir heróis, e não para criarmos lendas e vítimas" (idem, p.211). E o afirma categoricamente na primeira pessoa do plural, em nome, portanto, do seu grupo. Na visão deStanley, desmistificando a Maria da Fonte o poder instituído permanecerá garantido. É, no entanto, na penúltima cena da terceira parte que a questão do herói mais enfaticamente se coloca: "Nem no mundo há dois mundos/Nem no céu há dois senhores/Nem existe herói alado/Nem verdade de doutores”, recita o Falso Cego, voltado para o público, abrindo a cena na qual, dentre as três mulheres, Maria Ricarda, Maria Henriques e Maria Angelina, a última será apontada como a Maria da Fonte. Depois da recitação do Falso Cego, o palco inteiro é iluminado e veem-se as três mulheres alinhadas ao fundo, em cenário que representa o cárcere: "ao alto, por detrás delas, três postigos de cárcere desenhados a branco no pano negro da noite-as grades simplesmente" (idem, p.219). É então que o Falso Cego se pronuncia e sua fala nos remete à frase do Galileu de Brecht:

\section{O Falso Cego:}

Guerra que precisa de heróis não é guerra. Partido que pro- 
cura heróis não é partido. (Pausa de quem esgotou um discurso preparado.) Suponhamos um sujeito que abala um belo dia de casa. Abala um belo dia de casa, põe a clavina ao ombro e ligase a outros para fazer a guerra. Assanha-se, vende a pele pelo preço da alma, mata mais ou mata menos - conforme. É isso ser herói? (Nova pausa.) Outro subiu ao alto duns penhascos e vira-se cá para baixo para os companheiros: "Meus irmãos, notem bem no que eu faço! Vejam como eu encaro a morte!" Vem uma bala, zás: leva-o. É isso ser herói? Também não.

\section{Segunda Comadre:}

Tudo porque os heróis não morrem, e tudo porque não pode haver heróis solitários.

\section{Falso Cego:}

Logo, ai do que morre para se fazer de herói [...]. (idem, p. 220-1)

No discurso do Falso Cego há uma crítica explícita à sociedade que precisa de heróis ou mártires que, em prol de uma causa, põem em risco a própria vida. Cabe, no caso, o comentário de Raymond Williams (2002, p.256) sobre a questão do herói na obra dramática de Brecht: "do mesmo modo que é uma sociedade má aquela que necessita de heróis, assim também é uma vida má aquela que necessita do sacrifício". A repetida pergunta "É isso ser herói?" tem já implícita a resposta que, ao fim e ao cabo, nega a existência e a necessidade do herói.

De acordo com Anatol Rosenfeld (1996, p.50), o Galileu de Brecht não é um herói, "já que praticou a ciência como uma espécie de vício, sem nenhum compromisso para com a humanidade”. Concordando com a afirmação de Rosenfeld sobre Galileu, vemos o mesmo acontecer na trajetória da personagem Maria Angelina que, como vimos, também não é heroína. Dentre todas as personagens, o Falso Cego se destaca pela atitude anti-heróica, acentuada no seu discurso há 
pouco citado. Irônico, é ele quem, cantando trovas e poemas, narra e põe em julgamento as ações de outras personagens e, ainda, analisa de forma satírica a situação social e sua própria condição, queé também a de muitos outros. É preciso, então, fingir-se de cego para sobreviver. O Falso Cegoé, na verdade, a representação do anti-herói, pelo seu pensamento e atitude, por também negar categoricamente a necessidade ou existência do herói. Maria da Fonte, na peça, também representa o anti-herói em comparação com a figura mítica da Maria da Fonte "entronizada" nos livros pela história oficial.

Como aponta Maria HelenaWerneck (2005, p.229), José Cardoso Pires tinha como recomendação aos diretores de teatro não encenar $O$ render dos heróis em "estilo heroico":

Deixar de lado o gênero heróico e optar por outra forma, em que tanto caiba o "segredar do medo" quanto elementos satíricos, já se pronunciava como opção estética desde o Prólogo [...]. Por outro lado, anunciando uma prática escritural que recria convenções do gênero revista, José Cardoso Pires pretende enfatizar a narratividade épica da cena em $O$ render dos heróis.

As convenções do teatro de revista se fazem notar especialmente na apoteose grotesca, que apresenta características que se aproximam do distanciamento brechtiano.

A negação do "estilo heroico" está posta na peça desde o título até a composição de personagens anti-heroicas, e é isso que Cardoso Pires, em sua recomendação, espera que se preserve na encenação.

\section{A "apoteose grotesca": satírica e distanciada}

Cardoso Pires buscou nos poemas de Afonso Duarte (1884-1958) e em textos da criação artística popular o ma- 
terial para a composição das canções de $O$ render dos heróis. As trovas que o Cego canta na primeira parte da peça são versos transcritos dos volumes Sibila e Ossadas, de Afonso Duarte. Dos estudos e registros do historiador do século XIX Oliveira Martins (1845-1894) ${ }^{6}$ foi extraída a base histórica de $O$ render dos heróis, peça em que a citação e a alusão são os procedimentos utilizados na composição das canções e, em menor número, das recitações e dos coros de sua fábula histórica. Por meio da linguagem verbal e visual, tais citações e alusões revelam o caráter ideológico da peça, o qual, por sua vez, define uma clara visão de um mundo de opressores e oprimidos, da impotência dos homens frente às forças do Poder.

A caracterização da "apoteose grotesca" é uma alusão às caricaturas das personagens históricas publicadas nos jornais da época, principalmente no "Suplemento Burlesco" de $O$ Patriota. ${ }^{7}$ As características das personagens históricas do andor de Costa Cabral, indicadas na rubrica da cena final, são as mesmas das caricaturas do referido jornal descritas por Oliveira Martins (1895, p.269-70):

O Suplemento Burlesco, em lithographias toscas e caricaturas grotescas, insultava diariamente os Cabraes e a sua gente, mostrando que o antigo genio soez da satyra portugueza não se extinguira. Aqui vinha o Triumpho do Chibo: um bode (o conde

6 O livro Portugal contemporâneo, de Oliveira Martins, os poemas de Afonso Duarte, as contribuições poéticas populares publicadas na imprensa do século XIX e as caricaturas do "Suplemento Burlesco" são informações dadas à parte, isto é, fora do texto da peça, no final do livro $O$ render dos heróis.

7 O Patriota era um jornal de oposição ao Cabralismo e, no seu "Suplemento Burlesco", mostrava frequentemente Costa Cabral travestido de cabra. Cardoso Pires informa que "a figuração da 'Apoteose Grotesca' foi inspirada em caricaturas da época publicadas no 'Suplemento Burlesco' do jornal O Patriota durante o ano de 1847” (Cardoso Pires, 1970). 
de Thomar) com um sacco aos hombros e o letreiro roubo; o chibo sobre um andor que é um cofre, o Thesouro, levado por Saldanha e por José Cabral, o dos conegos, de vestes talares.

A rubrica da peça descreve de forma semelhante o "andor de Costa Cabral":

Entra o andor de Costa Cabral: É uma arca descomunal, a letras garrafais - "ARCA DO TESOURO" - e sustentada por quatro varas. A uma vem Stanley; a outra um sujeito vestido de cônego com uma legenda ao peito - "ZÉ (DOS CÓNEGOS) DA SILVA CABRAL, REI DO NORTE”; à terceira aparece um velho com uma casaca vestida às avessas e um dístico - "SALDANHA" - e, por último, um marreco, todo condecorado com cifrões de lata [...]. Costa Cabral vem no cimo do andor, à sombra de uma grinalda onde se lê: “ANTÓNIO BERNARDO DA COSTA CABRAL". Está vestido de bode, com um rabo terminado em seta como o dos mafarricos; distribui cortesias a torto e a direito. (Cardoso Pires, 1970, p.251-2)

Toda a caracterização da apoteose, pela deformação das personagens e pela movimentação de cortejo oficial aqui tornado ridículo, é a da imagem caricatural da situação política de Portugal em 1847, quando da volta do Cabralismo, mostrando, por meio da sátira, uma crítica aos mecanismos ilícitos do Poder. A cena é constituída pela movimentação do cortejo: "pessoa a pessoa, grupo a grupo, vai-se fazendo vagarosamente o desfile com a imponência das grandes ocasiões" (idem, p.249).

A imponência dos movimentos obviamente contrasta com a forma de trajar das personagens. Instaura-se, pois, a sátira. No grupo não está presente a rainha D. Maria II, mas o General Espanhol trata de gritar um "Viva, la reina! Viva, Portugal!" e um "Viva" de vozes se faz ouvir no palco e fora dele. Além dessa, há apenas mais uma fala do Dr. Silveira 
em tom de quem discursa: "Ordem! Sossego nos espíritos! Sejamos cordatos e saibamos perdoar. Não nos julguemos únicos donos da razão porque em toda parte ela é digna de se encontrar. No palácio do rico como na choupana do pobre" (idem, p.250). No lugar de falas, frases escritas em cartazes carregados pelas personagens, conhecido procedimento brechtiano. O fiscal leva um cartaz no qual está escrito "A lei exige desvelo"; a Baronesa de Stanley leva outro: "Mães agradecidas, só Deus sabe o que sofremos”.

A "cena muda" no final da apoteose - em que as personagens abrem e fecham a boca como se vociferassem ou comentassem, apontando para o Falso Cego com o letreiro ao pescoço "Já vi, agora não vejo" -, torna-se a representação da repressão àqueles que já "viram”, isto é, àqueles que, com a revolução popular, se conscientizaram do regime de repressão do governo, como acontece com o Falso Cego, mesmo que agora pareçam não ver.

No ano seguinte à publicação da peça de Cardoso Pires, em artigo publicado no Diário de Notícias, João Gaspar Simões (2004, p.96) afirmava que "O espírito que preside à concepção de $O$ render dos heróis é satírico”, e relacionava essa característica à matéria histórica retomada na peça:

Não que se utilize nele [espírito satírico] uma sátira à maneira queirosiana, mas a sátira que um "libertino" pode segregar quando por ventura lança mão de um tema em si mesmo tão mitificado que se não pode dizer concretamente onde estão nele os heróis, e o que valem, de facto, como heróis.

Concretizada completamente na "apoteose grotesca", a vertente satírica é, de fato, resultante das formas ridículas e grotescas com as quais são caracterizadas as personagens nas cenas finais: "Em vez de chapéu alto [os pares do reino] trazem panelas enfiadas na cabeça e, à maneira de medalhas, uma quantidade de talheres pendurados. No colar 
da comenda uma perna de frango" (Cardoso Pires, 1970, p.250). A alusão às caricaturas da época, configuradas na "apoteose grotesca", promove, por meio do espírito satírico, o distanciamento do público e, por conseguinte, o despertar da crítica.

Anatol Rosenfeld explica que, na estética do teatro épico, o elemento cômico unido ao didático tem como resultado a sátira. Entre os recursos satíricos utilizados está também o grotesco:

Não é preciso dizer que a própria essência do grotesco é “tornar estranho" pela associação do incoerente, pela conjugação do díspar, pela fusão do que não se casa [...] No grotesco, Brecht se aproxima de outras correntes atuais, como por exemplo do Teatro deVanguarda ou da obra de Kafka. Brecht, porém, usa recursos grotescos e torna o mundo desfamiliar a fim de explicar e orientar. (Rosenfeld, 2006, p.158)

Na figuração da "apoteose grotesca" de Cardoso Pires - na qual as características das personagens se assemelham às máscaras brechtianas ${ }^{8}$ e atingem somente as classes superiores -, o elemento conhecido (a volta dos Cabrais) transforma-se em elemento estranho pela caracterização ridícula das personagens. Essa imagem de estranheza que se forma na cena é ainda enfatizada pelo fato de ser a personagem de Costa Cabral, vestida de bode, a que, ao correr o pano negro, mostra, com esse gesto, o funcionamento do teatro, acentuando, pois, o efeito de distanciamento.

Assim, Cardoso Pires recontextualiza, de forma alegórica, as caricaturas das figuras políticas do século XIX - publica-

8 Anatol Rosenfeld (2006, p.158-9) cita exemplos de caracterizações grotescas nas encenações de Brecht: “[...] os soldados e o sargento de Homem é Homem apareciam como monstros enormes, mediante o uso de pernas de pau e cabides de arame, acrescentados de gigantescas mãos artificiais e máscaras parciais”. 
das na imprensa portuguesa da época - por meio de uma linguagem teatral que produz o mesmo efeito de distanciamento crítico que a sátira implica. Consegue criar, a partir da alusão, uma nova expressão artística para a mesma matéria criticada na contemporaneidade do acontecimento que agora é passado (histórico). 


\title{
4 \\ FELIZMENTE HÁ LUAR!, A FÁBULA hISTÓRICA DE StTAU MonteIRo
}

\author{
De facto, das colinas de Lisboa \\ vê-se arder ao longe a fogueira \\ que consome o corpo do general. \\ E são essas chamas, essas sinistras \\ labaredas, que cento e quarenta e \\ sete anos depois voltam a ser vistas \\ a distância. Quem no-las mostra? \\ Quem no-las faz ver? O autor desta \\ tragédia descarnada e vibrante que \\ chegou ao limiar da arte dramática \\ no momento predestinado para \\ nos apontar as labaredas de uma \\ fogueira que nunca mais se apagará.
}

(Simões, 2004, p.141)

Na esteira de $O$ render dos heróis, de Cardoso Pires, Felizmente há luar! (1961), fábula histórica de Luís de Sttau Monteiro (1926-1993), trata, também de forma alegórica, dos tempos do salazarismo. A peça narra os fatos históricos de Portugal referentes às aspirações liberais que precederam a Revolução de 1820, e conta com o trabalho do leitor/ espectador para fazer uma reflexão sobre os acontecimentos narrados a fim de analisar criticamente o regime político di- 
tatorial de Salazar. Assim, a retomada do episódio histórico é uma forma de falar do passado com vistas à análise do presente. Para tanto, Sttau Monteiro se vale de técnicas do teatro épico brechtiano, compondo um texto em que a narração, as orientações sobre a linguagem gestual dos atores e sobre as intenções das cenas são elementos estruturais e fundamentais para a caracterização épica da peça no sentido brechtiano.

A matéria histórica de Felizmente há luar! é o episódio da Conspiração de 1817. Sob a acusação de conspirarem contra o governo e instituições vigentes, muitas pessoas foram presase 12 delas, depois de processadas e rapidamente julgadas, foram sentenciadas à forca. A peça narra, com efeito, os acontecimentos relacionados à prisão e execução do general Gomes Freire de Andrade (1757-1817), acusado pelos governadores do reino - William Beresford, o Principal Sousa e D. Miguel Pereira Forjaz - de ter sido o líder da Conspiração Liberal. Gomes Freire, que se opunha ao domínio inglês sobre Portugal durante a ausência de D. JoãoVI, foi preso em 1817, com mais outros conjurados, tendo sido enforcado e seu corpo queimado publicamente em Lisboa no mesmo ano. Oliveira Marques (1998, p.15) explica que a execução

teve profunda influência no surto de uma consciência liberal entre o Exército e a burocracia. Longe de evitar futuras rebeliões, apenas serviu para as estimular, uma vez que os opositores ao regime, e com eles muitos outros até então indiferentes, se convenceram da tirania dos governantes e da impossibilidade de conseguir, por meios pacíficos, quaisquer modificações no statu quo.

Dividida em dois atos, a peça é construída principalmente pelo embate verbal entre as personagens que veem em Gomes Freire um aliado do povo, a lutar pelos interesses do povo (o Antigo Soldado, os populares, Sousa Falcão e Matilde de Melo), e as que veem nele um contestador do Poder 
vigente e, por isso, um general perigoso (os governadores do reino e os denunciantes: Vicente, Sarmento e Corvo). $\mathrm{O}$ primeiro ato expõe as maquinações dos governadores do reino que, a qualquer custo, querem nomear um líder para a conspiração liberal da qual ouviram falar. Para isso, contratam verdadeiros espiões - os denunciantes Corvo, Vicente e Morais Sarmento -, a fim de descobrir algum comprometimento. $\mathrm{O}$ anúncio, feito pelos denunciantes, do nome de Gomes Freire aos governadores do reino encerra o primeiro ato. No segundo ato, nomeado Gomes Freire líder da conjura e por isso preso na cadeia de São Julião da Barra, assistimos ao desespero de Matilde, sua companheira, na vã tentativa de pedir aos governadores pela vida do general, cujo fim trágico é narrado nas últimas cenas da peça.

A trajetória de Gomes Freire já tinha sido matéria para dois escritores: Teófilo Braga (1843-1924), que escreveu o drama histórico Gomes Freire (1907), e Raul Brandão (1867-1930), que publicou, em 1914, a sua pesquisa documental Vida e morte de Gomes Freire. ${ }^{1}$ Dessas duas obras, interessa-nos especialmente a de Raul Brandão, pois Vida

1 É sabido que, além de romancista, Raul Brandão era dramaturgo, apesar de suas peças não terem recebido a mesma atenção dada aos seus romances. Talvez ele não tenha escolhido o teatro para tratar da trajetória do general Gomes Freire pelo fato de seu contemporâneo Teófilo Braga ter dado expressão literária ao referido episódio no seu drama histórico Gomes Freire. Vida e morte de Gomes Freire teve três edições publicadas em vida do autor, tendo sido alterado o título da primeira edição, A Conspiração de 1817 (1814), para 1817: a Conspiração de Gomes Freire na segunda edição, de 1917. A terceira edição, de 1922, manteve o título da segunda. A quarta edição apresenta uma nota explicativa: "Num exemplar de trabalho da $3^{\mathrm{a}}$ edição, Brandão introduziu inúmeras correções e alguns acrescentos com vista a uma $4^{a}$ edição, na qual o título deveria passar a Vida e morte de Gomes Freire" (Brandão, 1990, p.13). Devido à campanha antiliberal da ditadura salazarista, essa quarta edição de Vida e morte de Gomes Freire, revista pelo próprio autor (falecido em 1930), foi publicada somente em 1987, com reimpressão em 1990. 
e morte de Gomes Freire é a base histórica para a criação de Felizmente há luar!, ainda que em nenhum momento Sttau Monteiro cite suas fontes. Simões (2004) define essa obra de Raul Brandão como "um trabalho de investigação e um esboço de dramatização”.

Para o historiadorVictor de Sá, no seu prefácio para Vida e morte de Gomes Freire, esta obra de Raul Brandão, escrita logo depois de proclamada a República em Portugal (1910), insere-se na "fase de propensão historicista e de registro histórico” (Brandão, 1990, p.6) do autor. Com efeito, Vidae morte de Gomes Freire apresenta a transcrição de documentos da época, de material de arquivo (por exemplo, do Arquivo do Ministério da Guerra: Pasta Especial), de notícias de jornal, de cartas inteiras (algumas inéditas até a publicação do livro) redigidas pelos atores dos acontecimentos (por exemplo, carta de Gomes Freire ao seu amigo Sousa Falcão e vice-versa; carta do marechal governador de Elvas, João Lobo Brandão, a Beresford); afora a profusão de notas de rodapé e a bibliografia comentada ao final do volume. Todas essas referências, citadas ou transcritas por Raul Brandão, conferem legitimidade à narração do episódio histórico - daí o valor documental da obra.

O conteúdo do "repositório documental" apresentado em Vida e morte de Gomes Freire foi transformado, na peça Felizmente há luar!, em diálogos concisos, dinâmicos, resultando em embates de grande dramaticidade, favorecidos pela construção da trama e pela extremamente elaborada caracterização das personagens, com grande capacidade de argumentação e explanação de suas ideias e pensamentos. Por vezes, informações documentadas em notas de rodapé em Vida e morte de Gomes Freire passam a ser os conteúdos de falas em Felizmente há luar!:

Forjaz ao I. G. Pol. ${ }^{\text {a }} 2^{\text {a }}$ feira, 26 de maio, às 7 da tarde. [Toda do punho de Forjaz] - Comunica a Beresford o ofício do 
Intendente de 26 e as cartas inclusas do Principal Sousa (não estão) e remete resposta a Beresford "estou absolutamente pelo que diz o marechal quanto ao pouco receio que deve haver acerca da segurança dos presos, mas enfim separem-se os que parecer conveniente como estava já determinado $\mathrm{eV}$. $\mathrm{S}^{\mathrm{a}}$ julgou necessário. Quanto porem à opinião do Sr. Principal de os mandar sair na Fragata com esta precipitação parece-me mui impolítico e inconveniente; he dar a tudo hum ar de violência e injustiça que servirá às mil maravilhas os projectos dos seus adherentes - quando ainda mal temos na mão as provas da existência de uma infame conjuração que convêm aclarar e punir para fazer ceçar a continuação desta gangrena [...] Esta decisão he muito melindrosa para que se tome com ligeireza" (Torre do Tombo: Pasta Especial). (idem, p.149-50)²

\section{Em Felizmente há luar!:}

\section{PRINCIPAL SOUSA}

Não seria preferível meter todos os conspiradores numa fragata, e mandá-los... [...]

\section{MIGUEL (Depois de um momento de espanto.)}

Aqui tem, Reverência, a resposta à sua pergunta. Não! Não e não! Meter gente numa fragata seria dar a tudo um ar de violência e de injustiça que só serviria os projectos dos seus aderentes. É preciso acabar de vez com esta gangrena. Já pensou em alguém, Reverência, que a Deus e ao Estado convenha liquidar? (Sttau Monteiro, 1980, p.73)

Há clara convergência entre as duas obras - a de Raul Brandão e a de Sttau Monteiro - quanto à interpretação

2 O editor de Vida e morte de Gomes Freire explica que "A ortografia do texto de Brandão foi actualizada, a dos documentos transcritos conservada. Os nomes próprios, por exemplo, estão pois em grafia actual no corpo do texto, mas aparecem na grafia da época quando constantes em documento citado." (Brandão, 1990, p.14). Nas citações, obedecemos a essa mesma norma. 
dos fatos que implicaram a morte de Gomes Freire e de outros ditos conjurados. Em síntese, ambas denunciam a ação autoritária e extrema praticada pelos governantes contra os contestadores:

Que distância de Raul Brandão a Luís de Sttau Monteiro! E, no entanto, os dois, por igual, compreenderam e sentiram a tragédia de S. Julião da Barra nas suas escuras maquinações, nos seus tremendos subterfúgios, nas suas impiedosas "razões de Estado" alimentadas pela cega obstinação dos que mais depressa renegam a justiça em nome de Deus do que Deus em nome da justiça. (Simões, 2004, p.141)

Os motivos da prisão e execução do general podem ser resumidos em duas falas de Felizmente há luar! proferidas por dois dos governadores do reino à Matilde. Quando esta suplica ao marechal inglês que o liberte porque o general não cometeu crime algum, Beresford lhe responde: "A simples existência de certos homens é já um crime” (Sttau Monteiro, 1980, p.108). E o Principal Sousa, ao ser acusado por ela de ter mandado prender e condenar um inocente, "em tom moderador" diz "As razões do Estado..." (idem, p.141). Nesse sentido, concordamos com o comentário de António Quadros (1964, p.241-2) sobre Felizmente há luar!:

É o antiquíssimo tema de Sófocles na Antígona patenteando a contradição, para os gregos irresolúveis, entre as leis explícitas do Estado e as leis implícitas de Deus ou da Razão ou de um princípio transcendente ao poder e ao mundo. A actualização histórica, social e filosófica de Luís de Sttau Monteiro alarga, porém, o prisma grego de visão [...] é o que partindo do gênero antagônico de cisão entre lei implícita e lei explícita, sublinha a angustiosa cisão entre os investidos do poder e o povo.

Gomes Freire não aparece efetivamente em cena, e, na lista de personagens de Felizmente há luar!, lemos a se- 
guinte indicação: “O GENERAL GOMES FREIRE D' ANDRADE - que está sempre presente, embora nunca apareça" (Sttau Monteiro, 1980, p.12), o que nos remete a uma semelhante definição em duas obras anteriormente publicadas. Em Vida e morte de Gomes Freire temos: "Gomes Freireé um inimigo que, mesmo calado, os incomoda." (Brandão, 1990, p.223). E no drama histórico Gomes Freire - cujo protagonista dá título à obra de Teófilo Braga-lemos a fala de uma personagem (José Pedro Marques, professor do Colégio Militar) que denuncia três nomes de inimigos de Beresford: “... e sempre essa figura, que não apparece, e se sente em toda a parte, Gomes Freire (...)” (Braga, 1907, p.37). ${ }^{3}$ Sttau Monteiro refere-se ao drama histórico de Teófilo Braga e à obra documental de Raul Brandão de forma indireta, sem citar essas fontes.

Essa "presença" sem aparição de Gomes Freire, ou essa presença que "não aparece", mas da qual se sabe, suprime a ênfase que se poderia dar à personagem como tal. Não sendo ela figura física, transforma-se em figura simbólica. A cena última de Matilde "a abraçar um ser imaginário", indica-nos a rubrica, a fazer o gesto de abotoar-lhe o casaco, tendo ao longe e ao fundo o clarão da fogueira, reconstrói uma imagem ou uma memória da figura de Gomes Freire, cuja presença e tudo o que ela pode significar é já tão clara: "Julguei que isto era o fim e afinal é o princípio. Aquela fogueira, António, há-de incendiar esta terra!” (Sttau Monteiro, 1980, p.164), diz Matilde. Assim, os motivos que levaram à morte de Gomes Freire sobressaem-se, ultrapassando sua figura física para torná-la símbolo de resistência, de contestação - e também de esperança, vivificando, por isso, sua presença.

3 Em todas as citações desta obra de Teófilo Braga, respeitaremos a ortografia da edição de 1907. 


\section{Papéis e gestos}

Ao abrirmos o livro que traz a peça Felizmente há luar!, deparamo-nos com uma divisão de todas as páginas em duas partes: a da direita, que traz os diálogos permeados de rubricas, como acontece usualmente em textos dramáticos; e a da esquerda, que apresenta rubricas apartadas do texto da fábula - às quais chamaremos de indicações paralelas. Mário Vilaça (1962, p.137), para quem as notas à margem do texto da peça deSttau Monteiro são “profusas e por vezes repetidas”, sugere que elas sejam ignoradas na encenação. Essas indicações paralelas podem, no entanto, representar uma preocupação com a forma ou estética empregada na encenação; elas constituem, portanto, não apenas orientações do dramaturgo ao diretor, mas refletem o momento político da época da criação da peça, como aponta Barata (1991, p.379):

Mais do que elementos para uma possível encenação (e na altura em que foi escrita representar Felizmente há luar! não passava de uma remota hipótese!) talvez o autor pensasse essencialmente numa "leitura orientada", sabendo que a peça dificilmente ultrapassaria o domínio do literário.

Sem descartar nenhuma das explicações da razão dessas rubricas do canto esquerdo da página, ou "notas à margem do texto", ou ainda orientações para a leitura, achamos que elas são importantes, pois nos indicam o tipo de gesto a ser assumido pelo ator; apresentam comentários do autor a respeito da situação referida e revelam a preocupação do dramaturgo em tornar clara a pretensão das cenas:

A pergunta é acompanhada dum gesto que revela a impotência da personagem perante o problema em causa. Este gesto é francamente "representado". O público tem de entender, logo de entrada, que tudo o que se vai passar no palco tem um significado preciso. (Sttau Monteiro, 1980, p.14) 
No início do segundo ato, Manuel, alterando o tom de voz, "sai" da personagem que narra - mudando totalmente o caráter da cena - para assumir, de forma alternada, outras duas personagens:

Manuel representa agora, e quase simultaneamente, dois papéis. Quando passa dum para o outro, os seus gestos devem ser rápidos e enérgicos para que o público compreenda o que se está passando.
Fala com ironia, mas a frase deve ser proferida de forma a compreender-se que ainda a dirige à personagem que se afasta.

Agora fala sozinho, e o seu tom de voz é, portanto, o habitual.
Uma esmola por alma de quem lá tem, meu senhor...

Também sou homem, também tenho fome, filhos que queriam ver homens, olhos para ver o luar, voz para dizer o que sinto, costas que morro a vergar... Uma esmola por alma de quem lá tem, senhor... (Estende a mão. Num gesto brusco toma a posição do indivíduo a quem estava a falar. Assume uma atitude nobre. Torna-se duro e ríspido). Tome lá cinco réis, homenzinho, e cale-se. Não me toque! Estenda a mão... vá! E deixe-se de lamúrias! Não preciso que me ensine os meus deveres de cristão; eu amo o próximo como a mim mesmo. (Faz o gesto de quem deixa cair uma moeda na mão dum pobre). Afaste-se! Deixe-me passar. (Dum salto volta à sua posição inicial, estende a mão $e$ adopta, novamente, o tom de voz anterior) Muito obrigado, meu senhor! (Faz uma vênia) Muito obrigado, meu senhor, pelo favor de me amardes como a vós mesmo. (Finge examinar a moeda imaginária que acaba de receber).

No Dia de Juízo, Deus Nosso Senhor levar-nos-á em conta estes cinco réis...

(Faz uma nova vênia e fica todo inclinado com os olhos na personagem imaginária que se afasta. Por fim, endireita-se e fica parado, no palco, em atitude de meditação.)

Esta madrugada prenderam Gomes Freire... Levaram-no escoltado para S. Julião da Barra. Já de lá não sai vivo! (Para o palco) Que mais sabem vocês da prisão do general? (Ilumina-se o fundo do palco, que se encontra repleto de gente do povo disposta exactamente como para a cena de abertura do primeiro acto).

(idem, p. 86-8) 
O diálogo estabelecido entre essas duas personagens representadas por Manuel mostra que o dever cristão de amar ao próximo como a si mesmo - se reduz a uma moeda de cinco réis, ironizando a máxima cristã. Dando a moeda ao pobre, o nobre sente ter cumprido seu dever e ter se livrado de "lamúrias". Essa pequena peça dentro da peça (protagonizada pelo mesmo ator que representa duas personagens) interrompe uma narração para introduzir outra. Assim, desfaz-se a continuidade cênica, de forma a salientar o caráter episódico da peça, nos moldes do teatro épico brechtiano.

A moeda de cinco réis torna-se então simbólica. Quando Matilde se dirige aos populares - "Você aí, sabe quem eu sou? Tenho lhe dado esmolas vezes sem conta" -, ninguém parece ouvi-la, até que Manuel lhe dirige a palavra:

Todos, aqui, sabemos quem a senhora é, e nenhum de nós é cego ou surdo [...]. Perguntou-nos, há pouco, o que íamos fazer para libertar o general... Insinuou mesmo que éramos responsáveis pela sua prisão, já que tínhamos fé nele... Olhe para nós, Sra. D. Matilde. Abra bem os olhos e veja quem somos e ao que estamos reduzidos [...] Mas nós passamos a vida inteira a ir ter convosco porque também não temos a quem recorrer! E que nos dão, senhores, que nos dão quando lhes batemos às portas no Inverno, com os filhos embrulhados em trapos, tão cheios duma fome que o pão, só por si, não satisfaz? (Pausa) Cinco réis, senhores! Dão-nos cinco réis ou dizem-nos que tenhamos paciência. (idem, p. 120-2)

No meio da fala, Manuel parece voltar-se para o público e para o "povo" do palco: "E o que nos dão, senhores?" Matilde pede a moeda - também ela, como todos ali, não sabe o que fazer. Manuel dá-lhe a moeda, mas não como esmola, e sim como uma medalha, para que a use no peito. Com esse gesto, é Matilde a assumir simbolicamente a função que seria de Gomes Freire, qual seja, a de não per- 
der as esperanças e continuar lutando, por isso a luz que iluminava o povo apaga-se e apenas a mulher permanece iluminada no palco.

Tanto nas indicações paralelas como nas rubricas entre os diálogos há orientações frequentes sobre os gestos dos atores, que muitas vezes sugerem oposição à dramaticidade das palavras, configurando, assim, uma proposta de linguagem corporal, bem próxima do gestus brechtiano, permitindo ao espectador compreender o sentido mais profundo da cena.

A linguagem gestual no teatro épico de Brecht define-se pela unidade que se constitui entre gesto e palavra; pode ocorrer, todavia, o caso em que o gesto é superior à palavra (Bolle, 1986). A personagem Matilde, por exemplo, vivifica na cena a imagem de Gomes Freire, representada pelo uniforme que ela acaricia e abraça; tal gesto é muito mais significativo que suas palavras, por simbolizar a personagem ausente. Quando a personagem Vicente, no primeiro ato, está a falar com os dois policiais sobre sua origem, seus gestos são detalhadamente descritos nas indicações paralelas. São todos gestos estudados, de pessoas da classe a que Vicente gostaria de ter pertencido: "Ao falar, faz gestos com as mãos, gestos lentos, precisos, copiados dum fidalgo qualquer que teve a ocasião de observar de perto" (Sttau Monteiro, 1980, p.28). São os gestos que, na encenação, contribuem para a caracterização dessa personagem. Como desdenha de sua própria origem, Vicente, nas cenas seguintes, irá se unir aos governadores do reino, inimigos de Gomes Freire, a fim de atingir o objetivo de ascender socialmente: "Cheira-me a coisa graúda... [a conversa marcada com D. Miguel Forjaz] Se eu souber fazer render o peixe, sou capaz de acabar com uma capela... ou chefe de polícia, quem sabe?" (idem, p.31) - e é o que ele consegue.

Na encenação épica, segundo Bolle (1986), a compreensão do discurso fica efetivamente clara se o sentido básico for 
expresso antecipadamente pelo gestus. É o que ocorre na cena em que Miguel Forjaz suborna Vicente: "Se cumprir essa missão com zelo que lhe impõe o seu dever [...] prometo-lhe que não acabará os seus dias a pedir. Interessa-lhe a chefia de um posto de polícia?” (Sttau Monteiro, 1980, p.40). O Principal Sousa "Estende o braço num gesto que, não sendo o da bênção, deve, todavia, sugeri-lo" (ibidem, grifo nosso), e diz a Vicente: "Vá, meu filho, e ajude-nos a cuidar do rebanho, indicando-nos as ovelhas tresmalhadas antes que elas contagiem as restantes. Que Deus o proteja na sua missão" (idem, p.40-1). Não sendo o da bênção, seu gesto abençoa tanto o suborno quanto a traição.

O trabalho gestual mais complexo aparece na cena em que ao se referir a Gomes Freire, o Antigo Soldado diz: "Quem fez aquele não fez outro igual...", momento em que Manuel inicia a frase, mas não a termina: "Se ele quisesse...”. Há um silêncio, acompanhado de um gesto das personagens que, diz a rubrica, "olham para as mãos e para os lados. Foram longe demais e sabem-no" (idem, p.20). O gesto de olhar para as mãos e para os lados, considerando o silêncio, destoa do entusiasmo e até da descontração com que essas personagens vinham conversando sobre Gomes Freire; é como se o gesto e o silêncio preparassem a entrada eminente de Vicente a contestar a importância dada a Gomes Freire por aqueles populares todos. A interrupção da frase, seguida do silêncio e dos gestos das personagens, rompe com a linearidade da cena, produzindo o distanciamento.

Tão precisa nas indicações paralelas, a descrição dos gestos nos permite fazer pelo menos duas suposições, apoiados nos comentários já tecidos por alguns críticos: a de que, de fato, Felizmente há luar! traz no texto uma clara orientação de leitura, ou a de que as indicações paralelas são direcionadas, na verdade, ao encenador. A única certeza é a de que uma suposição não exclui a outra. 


\section{Frase-título: histórica e distanciada}

Já transcrita por Teófilo Braga e Raul Brandão, a frasetítulo "Felizmente há luar" tornou-se de fato famosa com a peça de Sttau Monteiro. Ela dá o título ao décimo e último capítulo do livro de Raul Brandão, e aparece no epílogo do drama histórico de Teófilo Braga na fala da Dama (na verdade, D. Maria do Patrocínio, personagem que, no prólogo, dialoga com a viscondessa de Juromenha e depois com Gomes Freire):

A mão que eu beijava com piedade filial, a mão de meu tio, na hora tremenda das execuções bárbaras do Campo de Sant'Anna, escreveu esta execranda phrase: "É verdade que a execução se prolongará pela noite, mas felizmente há luar, $e$ parece-me tudo tão socegado, que espero não cause isto prejuizo algum..." Acabaram as execuções por um incendio pavoroso, mas prolonga-se a noite moral, em que parece tudo socegado, porque está em colapso de lethargia a consciencia do povo. (Braga, 1907, p.270, grifo do autor)

Sttau Monteiro não cita a fonte do título, tampouco a da matéria histórica que aproveita para a criação de sua peça: "é que a história ali [em Felizmente há luar!] não a documentam arquivos, não a comprovam testemunhos documentais" (Simões, 2004, p.140). Recorrendo aos documentos fornecidos por Raul Brandão e pelos historiadores, vamos confirmar que a frase "Felizmente há luar" saiu da pena de uma personalidade histórica, D. Miguel Pereira Forjaz (o "tio” da personagem na citação acima), um dos governadores do reino, em carta ao intendente geral da polícia na tarde da execução de Gomes Freire, em 18 de outubro de 1817:

[...] he verdade que a execução se prolongará pela noite, mas felizmente ha luar e parece-me tudo tão socegado que espero não cause isso prejuizo algum. Será bom que V. Sa me com- 
munique o que se passar. (Torre do Tombo: Arquivo da I. G. da P.). (Brandão, 1990, p.250, nota 3)

Além de usá-la como título da peça, Sttau Monteiro a incorpora à fala da personagem D. Miguel Forjaz em diálogo com o Principal Sousa, nas cenas finais do segundo ato, no momento em que eles comentam a execução dos conjurados condenados à forca e depois à fogueira:

\section{MIGUEL}

Lisboa há-de cheirar toda a noite a carne assada, Excelência, e o cheiro há-de-lhes ficar na memória durante muitos anos... Sempre que pensarem em discutir as nossas ordens, lembrar-se-ão do cheiro... (Com raiva) É verdade que a execução se prolongará pela noite, mas felizmente há luar... (Sttau Monteiro, 1980, p.153)

D. Miguel Forjaz é quem primeiro acusa Gomes Freire de conspiração, para, no segundo ato, negar-se a receber Matilde de Melo que vai lhe pedir auxílio em favor do companheiro. O tom da fala de D. Miguel, antes da raiva, é o da ameaça que reflete o seu abuso de autoridade. Ele quer "ensinar" por meio do exemplo-a execução de Gomes Freire - que conjuga a repressão e a força.

A mesma frase é repetida, em um "quase grito", por Matilde na última fala da peça, alterando, obviamente, o sentido das palavras:

\section{MATILDE \\ $[\ldots]$ \\ (Para o povo)}

Olhem bem! Limpem os olhos no clarão daquela fogueira e abram as almas ao que ela nos ensina! Até a noite foi feita para que a vísseis até o fim...

(Pausa)

Felizmente-felizmente - há luar! 
(Desaparece o clarão da fogueira. Ouve-se ao longe uma fanfarra que vai num crescendo de intensidade até cair o pano) (idem, p.164)

Matilde também quer ensinar, ela também toma o acontecimento narrado como exemplo, mas com o intuito contrário ao de Forjaz. Para Matilde, não é o cheiro que a memória guardará, mas a visão tornada possível pelo clarão da fogueira e pelo luar, metáfora da luz capaz de abrir as mentes para a análise crítica da realidade.

Marcando a contraposição entre esses dois tipos de "ensino", a frase "Felizmente há luar" é deslocada de uma personagem (D. Miguel Forjaz) para outra (Matilde de Melo), de um posicionamento ideológico (manutenção do Poder pela força e pela opressão) para outro (contestação do Poder pela crítica). E isso em um mesmo contexto políticosocial, o das aspirações liberais na primeira metade do século XIX, que deve espelhar a situação política de Portugal na década de 1960. Tal deslocamento modifica o significado da frase e amplia sua projeção. Na boca de Matilde, a frase traduz a esperança, porque ver a cruel execução significa ter a clara percepção da injustiça praticada contra aqueles que se opõem ao poder instituído, e isso não poderá jamais se repetir. Dita por ela, ao mesmo tempo em que ganha novo sentido, a frase provoca o distanciamento no espectador. Mesmo que o público desconheça o caráter histórico da frase, o efeito de distanciamento é provocado por seu deslocamento de uma para outra personagem. Oliveira Barata (1991, p. 378, grifo do autor) relaciona essa repetição da frase-título à divisão em dois atos da peça, em que o primeiro ato mostra o "funcionamento do poder" e o segundo, o "domínio do antipoder", de modo que

Felizmente há luar! Duplamente repetido. Anteriormente, cinicamente "anunciado por D. Miguel [...]. A duplici- 
dade de intenções desta elocução e o contexto situacional em que é proferida, serve assim, mais uma vez, a estrutura dual que se preocupa apresentar: a frase dita pelo Poder e dita pelo antipoder.

D. Miguel Forjaz é o representante do Poder no primeiro ato, e Matilde a do antipoder no segundo; muda a personagem e com ela o sentido atribuído à repetição da frase.

Em uma outra perspectiva de análise, vemos que a frase como título faz dupla referência: à redação do episódio histórico documentado por Raul Brandão e à ficcionalização da história por Teófilo Braga; dialoga, pois, com a história e com a literatura. A partir dos textos que registram o episódio, Sttau Monteiro relê e "reescreve" a história, mostrando de forma metafórica a possibilidade de transformação do processo histórico. É o que mostra Matilde ao repetir a frase de D. Miguel Forjaz, com a qual termina a peça. Assim, a peça assimila os pressupostos do teatro épico não apenas no que se refere aos aspectos técnicos formais, mas principalmente no tocante ao pensamento de Brecht e a sua intenção de desenvolver esse tipo de teatro. Em um de seus registros, o dramaturgo alemão afirmou que

o teatro épico interessa-se pelo comportamento dos homens uns para com os outros, sobretudo quando é um comportamento (típico) de significação histórico-social. Dá relevo a todas as cenas em que os homens se comportam de tal forma que as leis sociais a que estão sujeitos surjam em toda a sua evidência. E, ao fazê-lo, cabe-lhe descobrir definições praxísticas dos acontecimentos em processo, istoé, definições que, ao serem utilizadas, possibilitem uma intervenção nesses mesmos acontecimentos. [...] O comportamento humano é apresentado, no teatro épico, como sendo suscetível de transformação e, o homem, como dependente de determinadas condições econômico-políticas, condições que são, simultaneamente, capazes de modificar. (Brecht, 2005, p.228) 
Ao deslocar a frase para a última fala de Matilde, Sttau Monteiro, para além da estranheza provocada, confere ao espectador, na esteira de Brecht (ibidem), a "oportunidade para uma crítica do comportamento humano segundo uma perspectiva social e a cena é representada como cena histórica". Nessa relação do homem com a história, aquilo que lhe parecia conhecido se revela estranho, conforme a releitura da história proposta pela peça. Para Oliveira Barata (1991, p.379, grifo do autor):

A emergência da história no discurso dramático, privilegiando-se e remotivando-se um núcleo 'mítico' - ao qual o espectador não deveria aderir empaticamente -, satisfazia um duplo objectivo: servir de exemplo, para a reflexão, e, simultaneamente contribuir para a transformação da realidade contestada.

A reflexão produzida por Felizmente há luar!, frase e peça, está centrada metaforicamente na possibilidade de mudança, poisohomem "Nãoésó vítima da história; étambém propulsor dela” (Rosenfeld, 2006, p.172).Eéessa ideia-dequeohomem deve ter consciência de que depende da situação histórica, a qual, por sua vez, pode ser por ele transformada-quejustifica a desaprovação da peça pela comissão de censura de Salazar.

O fato histórico, tornado cênico, não pretende ser apenas representativo do passado, nem tampouco mostrar uma verdade histórica; longe dessas preocupações, a peça de Sttau Monteiro trabalha a inserção de textos da história, esperando do seu espectador/leitor não o reconhecimento do passado histórico, mas uma análise profunda desse passado como reflexão sobre o momento presente.

\section{Dimensão épico-brechtiana}

Sttau Monteiro faz uso de recursos narrativos, de gestos precisamente definidos nas indicações e de um cenário 
esvaziado de objetos cênicos, como ele próprio resume em uma das primeiras indicações paralelas: "os gestos, as palavras e o cenário são apenas elementos duma linguagem a que [o público] tem de adaptar-se" (Sttau Monteiro, 1980, p.13). É clara a preocupação do dramaturgo em avisar que estamos diante de outra linguagem, outra forma ou, ainda, outra estética dramática.

O fato de os dois atos começarem propositadamente da mesma forma, com a mesma frase - "Que posso eu fazer?" -, chama a atenção do leitor/espectador para a análise e comparação entre o que se narrou no primeiro ato e o que se começa a narrar no segundo. A repetição - da mesma pergunta pela mesma personagem, Manuel, e do mesmo enquadramento cênico: "os atores devem ocupar no início deste acto as mesmas posições que ocuparam no primeiro" - representa, no segundo ato, a falta de perspectiva dos populares perante a vigência impositiva do Poder: "E ficamos piores do que estávamos... Se tínhamos fome e esperança, ficamos só com fome... Se durante uns tempos acreditávamos em nós próprios, voltamos a não acreditar em nada" (idem, p.86). A prisão de Gomes Freire parece assinalar a perda da pouca esperança que havia, de par com o sentimento de que não há mais forças para resistir:

\section{SOUSA FALCÃO (Com ternura)}

Todos somos chamados pelo menos uma vez a desempenhar um papel que nos supera. É nesse momento que justificamos o resto da vida, perdida no desempenho de pequenos papéis indignos do que somos. (idem, p.100)

Matilde, personagem que vai se transformando no decorrer da peça, é quem irá restituir algum alento, na esperança de que a morte de Gomes Freire ensine algo aos homens.

O processo narrativo que confere dimensão épico-brechtiana à peça é ativado principalmente pelas funções de 
comentador - que assume a voz coletiva - e de narrador dos fatos, atribuídas a Manuel, "o mais consciente dos populares”, e pelos monólogos de Matilde.

O extenso monólogo de Matilde tem duas partes, separadas por um diálogo com Sousa Falcão, amigo de Gomes Freire. Nas duas partes, a mesma sequência de assuntos: o filho, o marido e, por fim, a decisão de lutar pela vida de Gomes Freire. É o que ela fará nas cenas seguintes, ao procurar os governadores do reino.

Quando Matilde entra em cena - para não mais deixar o palco -, sua fala "sozinha" tem, inicialmente, a mesma função dos recursos épicos brechtianos, qual seja, a de interromper a ação:

Ensina-se-lhes que sejam valentes, para um dia virem a ser julgados por covardes!

Ensina-se-lhes que sejam justos, para viverem num mundo em que reina a injustiça!

Ensina-se-lhes que sejam leais, para que a lealdade, um dia, os leve à forca!

(Levanta-se)

Não seria mais humano, mais honesto, ensiná-los, de pequeninos, a viverem em paz com a hipocrisia do mundo?

(Pausa)

Quem é mais feliz: o que luta por uma vida digna e acaba na forca, ou o que vive em paz com a sua inconsciência e acaba respeitado por todos?

(idem, p.92-3)

O contraste entre o tom poético desta fala e a cena imediatamente anterior ao surgimento de Matilde (enquanto os policiais desfazem o ajuntamento, Rita narra a reação de Matilde ante a prisão do companheiro) quebra a dinâmica da encenação, tornando-a estática. A mudança de ritmo, aliada ao uso de antíteses e anáforas na fala de Matilde, provoca o efeito de distanciamento. 
Para Fernando Mendonça (1971, p.102) “Luís de Sttau Monteiro estabeleceu o modelo que nos oferece uma linguagem dramática [composta por diálogos] coordenada numa sintaxe épica [narrativa]". Mas nem sempre a linguagem é específica ou totalmente dramática. É o caso do monólogo de Matilde, que se estende por todo o segundo ato.

Sabe-se que o monólogo foi uma forma firmemente recusada pelo teatro naturalista devido à sua inverossimilhança - ninguém fala tanto tempo sozinho em voz alta -e por representar uma paralisação da ação, função rejeitada por esse tipo de teatro que preza justamente a linearidade da ação. Para o teatro épico, ele traz uma vantagem, a de interromper a ação, revelando a teatralização, mas também uma desvantagem porque pode configurar-se em um discurso que a personagem faz para si mesma, em uma "linguagem interior" entre o "eu locutor" e o "eu ouvinte" (Pavis, 2007). Segundo Bornheim (1992, p.324), Brecht resolve bem a questão, lançando o monólogo para o épico, ou seja, utiliza-o como uma técnica - afinal, "canções e comentários são quase monólogos" e servem para distanciar a ação; por isso, "talvez caiba dizer que o que cai por terra [no teatro épico] não é propriamente o monólogo tradicional, e sim a quarta parede, o palco já não se fecha mais contra o público”.

Voltando ao monólogo de Matilde, verificamos que ele, em sua extensão, apresenta ainda outras características, além da função de interromper a ação:

Um dia, encontramos o nosso homem a sonhar um outro mundo - sabemos que esse sonho põe termo à paz que tanto desejamos, e, mesmo assim, queremos dizer-lhe que siga o seu caminho, que iremos com ele até ao fim, mas não sabemos por onde começar... (Sttau Monteiro, 1980, p.102)

A primeira pessoa do plural estabelece uma aproximação com o espectador (em especial com as mulheres: mães e 
esposas), tornando grande a probabilidade de o espectador identificar-se com essas palavras. À primeira vista, essa passagem do monólogo parece contrariar a orientação das indicações paralelas, de que "ninguém esboce um gesto para cativar ou acamaradar com o público". Cumpre ressaltar, no entanto, o sentido pedagógico do texto que se estrutura na citação de um exemplo que, acionado, funciona como contributo ao ensino. Trata-se, portanto, mais de uma estratégia pedagógica que de uma técnica de identificação. É a vida dessa mulher ao lado do homem amado que ensinou a ela uma nova forma de ver o mundo que o monólogo transmite e a peça quer ensinar.

Em Felizmente há luar! as personagens se movimentam no palco, indo de um a outro espaço subentendido pela ação ou pela presença de outras personagens, já que não há exatamente um cenário, apenas objetos como cadeiras, caixotes, uma cômoda e outros. Nas cenas em que aparecem os populares, por exemplo, dá-se a entender que eles estão em um espaço público, em uma rua ou em uma praça, mas não há indicação de serem, de fato, esses lugares. Da mesma forma que as personagens "surgem" no palco, surgem também os objetos de cena; da mesma forma que os gestos não podem sobrar ou aparecer sem função, os objetos também não; por isso há uma economia do uso de materiais cênicos. O exemplo mais claro é a cômoda que "surge" na cena em que Matilde fala sozinha, no segundo ato. Desse móvel, ela tira o uniforme de Gomes Freire, o qual acaricia com ternura enquanto fala. Nesta mesma cena, há um momento em que Matilde faz o gesto de fechar uma janela, à qual se tinha referido anteriormente: "Abríamos a janela ao sol da manhã e aquecíamo-nos os dois..." (idem, p.94); muito curioso é que não há uma indicação do gesto de abrir a janela, como se as palavras - "Abríamos a janela” - substituíssem o gesto e os dois (gesto e palavras) substituíssem o objeto cênico. As indicações no texto são 
tão precisas, que, quando lemos um comentário sobre a peça como o de Simões (2004, p.140), originalmente escrito em 1962, temos a impressão de que ele fala da encenação e não do texto da peça, à altura ainda impedida de ser representada nos palcos portugueses:

A primeira peça histórica sem barbas postiças nem castelos de papelão. Um palco aberto e alguns projectores incidindo sobre uma cena às escuras. É aí, nessa boca de cena tão despojada e tão nua como a de qualquer tragédia clássica ou de qualquer auto de Gil Vicente [...] que se desenrola a tragédia de Gomes Freire, protagonista invisível de Felizmente há luar!

Da perspectiva do teatro épico brechtiano, os objetos cenográficos não precisam estar efetivamente presentes; basta que sejam sugeridos ou que a eles se faça alusão, como faz Matilde ao fechar uma janela que não há.

Em algumas cenas, as autoridades são simbolizadas apenas pelo som dos tambores e sinos. Os sinos representam a autoridade religiosa e os tambores indicam a aproximação dos militares. Quando os sons desses sinos e tambores são ouvidos pelas personagens, elas mudam de atitude, de gestos, e a cena é imediatamente modificada, desfazendo a linearidade da sequência cênica.

A caracterização da linguagem cênica, bem como a forma como a fábula é desenvolvida, põe a peça de Sttau Monteiro em consonância com a estética teatral brechtiana. Felizmente há luar! apresenta técnicas de distanciamento sem reduzir a teoria de Brecht a uma fórmula ou esquema; talvez seja por isso que, na peça, não vemos aqueles recursos épicos mais famosos que marcaram a encenação desse tipo de teatro, como projeções de filmes, títulos nas cenas, cartazes e outros. Na verdade, o caráter épico da peça, para além da estrutura, apresenta-se em outra dimensão, muito embora se aproveitando da forma proposta por Brecht. 
A repetição da frase-título por personagens antagônicase a repetição do enquadramento cênico no início dos dois atos afinam-se no caráter dialético das relações político-sociais constituintes do processo histórico e debatidas na peça. As contradições no processo são notórias: o povo não promove nenhuma ação em favor da libertação do general; Matilde, personagem também do povo, é a primeira a cobrar uma ação dos populares: "Por quanto tempo é que o vão deixar metido numa masmorra, perdendo aos poucos a fé que tinha na gente desta terra?" (Sttau Monteiro, 1980, p.116); Gomes Freire é delatado por Corvo, Sarmento eVicente, pessoas do povo que lutam pelos seus interesses individuais, igualandose, por isso, aos governadores do reino. É a exposição/narração dessas contradições que chama a atenção do espectador e o leva à análise crítica da realidade em que ele se insere, de modo que "Se o teatro ignorasse que tudo é contradição, procurando de algum modo encobrir esse fato, representaria a falsificação da própria realidade. Assim, o que vale para o social e para o indivíduo deve valer também para o texto dramático e para as personagens" (Bornheim, 1992, p.272); por isso, os conflitos são expostos como conflitos sociais, a contradição é intrínseca a eles e precisa, pois, aparecer na peça-como, de fato, aparece. 


\title{
Considerações finaIS
}

\author{
Apesar de todos os desafios, \\ provocações e interdições, \\ nunca o teatro deixará de ser \\ a imagem da vida em profundidade \\ em movimento, nunca se cansará \\ de encorajar os homens a dizer \\ que não a tudo o que os mutila, \\ os rebaixa, os diminui, os desfigura, \\ os oprime, e a roubar o fogo \\ àqueles que abusivamente o retêm \\ nas suas mãos. Para distribuí-lo \\ por todos. \\ (Rebello, 1972, p.253, \\ grifo do autor)
}

Se logo depois da Segunda Guerra, e mais especificamente na década de 1960, o teatro português passa a ter outra configuração mais ou menos em conformidade com as novas estéticas teatrais que já se praticavam mundo afora, um dado que contribui para essa movimentação na cena teatral é a existência inegável de uma crescente oposição ao regime de Salazar. Paulatinamente as rédeas do poder iam sofrendo abalos aqui e ali. 
O período em que as peças de Cardoso Pires e de Sttau Monteiro foram publicadas é marcado pelo crescimento dos movimentos oposicionistas ao salazarismo. É a fase da “agitação", como bem definiu Oliveira Marques (1998). Já aqui mencionamos a crise política de 1958, com as eleições para presidente, quando Humberto Delgado, concorrendo ao cargo, atraiu o interesse de um grandioso número de portugueses preocupados com a situação política do país. Em 1961, Delgado e Henrique Galvão chefiavam a captura do paquete Santa Maria por exilados políticos. Ainda em 1961, uma tentativa (fracassada) de golpe de Estado contra Salazar era liderada pelo Ministro da Defesa, Botelho Moniz; o exército indiano invadia as possessões portuguesas na Índia - Goa, Damão e Diu; e nas colônias africanas começavam as guerrilhas pela independência. Em 1962, uma rebelião militar era imediatamente reprimida em Beja, enquanto protestos do movimento estudantil e de outros segmentos da sociedade eclodiam em greves e manifestações. Mas Salazar continuava no Poder...

Já desde 1946, com o microteatro do grupo TeatroEstúdio do Salitre, de Luiz Francisco Rebello, Gino Saviotti eVasco Mendonça Alves e suas novas ideias de dramaturgia e encenação antinaturalistas, os artistas de teatro propunham um olhar crítico para a realidade, influenciando grupos que nasciam e conquistando a adesão de outros que se voltavam para os mesmos propósitos. Claro, o teatro batia de frente com as ideias salazaristas.

Salazar era contrário às mudanças, valorizava a tradição, queria que os cidadãos lusos ficassem "orgulhosamente sós" no seu "Mundo Português", criado ficticiamente para a contemplação e exaltação do passado histórico, a fim de "confirmar" que no presente se vivia bem. O ditador procurava fazer crer que a história é uma "evolução sem sobressaltos" (Santos, 2004) e que, por isso, os portugueses deveriam viver normalmente, como de costume, comemorar 
e celebrar o passado histórico que os ajudara a chegar aonde chegaram! A Exposição do Mundo Português em $1940^{1}$ foi o "grande show" do regime, como declarou o comissário-geral da exposição, Augusto Castro (idem). Era o ano dos centenários e comemorações (1140: fundação de Portugal; 1640: restauração da dinastia nacional e coroação de D. João IV); e 1940 era, nas palavras de António Ferro: ${ }^{2}$ o "ano apoteótico do ressurgimento". Viria daí a ideia de apoteose grotesca e trágica de Cardoso Pires e de Sttau Monteiro?

Esses dois autores, como vimos, tomaram fatos históricos de Portugal para a construção de suas fábulas. Nesse sentido, não sem ironia se punham de acordo com os preceitos do regime, que enaltecia a história do país. Era o que a gente toda, isto é, o público, conhecia. Então, nada mais natural. Cardoso Pires vai ainda mais longe ao escolher um episódio ocorrido justamente na zona rural para construir a sua fábula. Ora, era o que Salazar aprovava, pois ele, o ditador, valorizava a vida aldeã:

Esta afirmação da superioridade da vida no campo sobre a vida urbana articula-se com a noção de humildade pregada pelo regime e que fazia parte do retrato psicológico dos

1 Inaugurada solenemente em Lisboa, em 23 de junho de 1940 (encerrada em dezembro do mesmo ano), a exposição aconteceu em três conjuntos de edifícios, um consagrado à História, outro à Etnografia Metropolitana e o terceiro à Etnografia Colonial. Tinha como objetivo apresentar o estilo português de 1940. Muitos artistas foram chamados para "criar" esse estilo; a intenção, na verdade, era a de inventar uma identidade nacional que seria então celebrada durante todo o regime. Os historiadores informam que a exposição recebeu perto de três milhões de visitantes.

2 Segundo Graça dos Santos (2004, p.67), para Antonio Ferro - chefe responsável do Secretariado de Propaganda Nacional (SPN) do regime e secretário-geral da Exposição -, 1140, 1640 e 1940 eram os anos sagrados para a história de Portugal, sendo respectivamente “ano do crescimento", "ano do renascimento" e, como já citamos, “ano apoteótico do ressurgimento”. 
portugueses idealizado pelo chefe do Estado Novo. Donde a placidez patriarcal e rústica do campo, em oposição à agitação e convulsão citadinas, o que é também uma forma de incitar os camponeses a permanecerem no campo.

(idem, p.68-9)

Para Cardoso Pires, o teatro é uma leitura e sua leitura da revolta popular da Maria da Fonte é uma forma de manifestação artística contra o regime. Na peça, não existe ingenuidade das pessoas do campo; há, sim, uma impotência diante do Poder, e por isso há gente fingindo-se de cega para sobreviver. Se pensarmos que Vilar - a aldeia apresentada em O render dos heróis - é a representação "microcósmica" de Portugal da segunda metade do século XX, podemos tirar daí pelo menos duas assertivas. Uma, que Cardoso Pires mostra uma vida aldeã com homens que têm plena consciência da situação de opressão em que se encontram, uma vez que a peça começa, vale lembrar, pela narração dos motins iniciais da revolta popular, contrariando, pois, a vontade do regime, que quer fazer acreditar que a vida no campo é desprovida de mudança ou agitação e, por isso, é a representação da tradição. Outra que, mesmo tendo sido reprimida, houve uma tentativa de revolta que, sem a dependência de um herói, fez, ainda assim, valer, se não a transformação desejada, pelo menos o despertar da consciência para a realidade.

Não há na expressão que constitui o título $O$ render dos heróis pessimismo ou negatividade, mas o claro convite à reflexão. Se a história era, para o regime, a exaltação de heróis e de feitos históricos, na peça de Cardoso Pires a fábula mostra que a história não precisa de heróis - pelo menos a história que agora se constrói. A peça revela que a história é um processo e, como tal, é dinâmica, no sentido de que está sempre em transformação e, mais, de que não existe evolução sem sobressaltos. O fato de Maria Angelina ser, na 
peça, a Maria da Fonte não tem importância alguma. Teria se estivesse o autor preocupado em construir sobre a figura, líder da revolta popular, uma imagem de herói; mas não. A dúvida que perpassa as falas de algumas personagens - "será esta a Maria da Fonte?” - indica uma compreensão da mentalidade de certa parcela da população, muito acostumada ao regime, que ainda acreditava na necessidade de um líder que a comandasse. Cada cena da peça é uma etapa na desmontagem da ideia de líder, de herói. Cumpre lembrar queé depois das argumentações do Falso Cego sobre a questão do herói que se decide por Maria Angelina ser a Maria da Fonte porque, nesse ponto da peça, não importa mais quem seja a líder; afinal, já se transmitiu a mensagem ou o ensinamento de que é "infeliz a terra que precisa de heróis".

A apoteose grotesca de Cardoso Pires, no final da peça, é uma sátira ao ritual dos cortejos e às festividades cívicas comemorativas patrocinadas pelo regime de Salazar ou por qualquer outro regime totalitário. O sentido da comemoração nesses regimes liga-se à visão da história criada por seus ditadores. É verdade que Salazar, o real chefe do Estado, evitava participar de tais eventos, mas não deixava de promovê-los por todos os cantos do país, mesmo porque era por meio deles que se aplicava e se expandia a propaganda de seu governo e, ao mesmo tempo, compensava-se a realidade social em decadência: "O poder da comemoração é justamente o de criar o acontecimento, aproveitando a carga simbólica de um facto anterior. Serve assim para consagrar o vazio de sentido deixado pela história, recheando-o de todos os artifícios de uma reinterpretação solene" (idem, p.68).

Eé solenemente que entra em cena, na apoteose grotesca de $O$ render dos heróis, o andor de Costa Cabral, outro ditador da história. Esse cortejo solene é criticado veementemente sem que se diga uma palavra sequer. $\mathrm{O}$ visual fala por si: o ditador vestido de bode, talheres em lugar de medalhas no peito dos pares do reino, panelas no lugar de chapéus nas 
cabeças dos barões; o quadro é, de fato, grotesco no sentido etimológico do termo. A cena, literalmente muda, grita para os espectadores para que não apenas vejam, mas analisem criticamente a real situação. Se a ditadura salazarista utilizava as comemorações e festividades como meios para convencer a população da grandeza do passado do país, que a propaganda do regime ditatorial propunha exaltar, a cena final de Cardoso Pires se vale dos mesmos meios, mas para alcançar o efeito inverso, qual seja, o de despertar a consciência.

É possível traçar um paralelo entre as duas apoteoses: a pretendida pela Exposição do Mundo Português e a da peça de Cardoso Pires. Em ambas, o que se pretende é criar a "consciência nacional" por meio da relação passadopresente. No entanto, se a primeira, ocorrida vinte anos antes da publicação da peça e tendo marcado a história recente do país, pretendia que "os visitantes saíssem mais exaltados que propriamente instruídos” (idem), a segunda tem por objetivo impedir que os espectadores saiam emocionalmente satisfeitos, mas "socialmente insatisfeitos", como escreveu Mario Vilaça, em 1966, quando procurava definir o espectador do teatro épico. Cardoso Pires, então, inverte propositadamente a referência do seu leitor/espectador português acostumado, por mais de quarenta anos, a ver diante dos olhos tantas festividades e comemorações. O conhecido torna-se estranho e, por isso, distanciado. Nem é preciso repetir que a lição de Brecht se realiza de forma original justamente aí, nessa apoteose recriada por Cardoso Pires.

De fato, tornar estranho o conhecido é a mais clara característica do engenho e da arte de Cardoso Pires nessa que é sua primeira e penúltima criação dramática. Ele trabalha com a aproximação do referencial e dele se distancia deliberadamente para que se processe o despertar da crítica. Dessa forma, primeiro seleciona o material: fato histórico 
conhecido ocorrido no campo, poesia de Afonso Duarte (falecido em 1958, cujos poemas versam sobre a vida no campo, o folclore, as aldeias etc.) e caricaturas das personalidades do episódio histórico, publicadas nos jornais da época; em seguida, rearranja tudo fazendo uma releitura do fato histórico em que desconstrói a figura heroica da que seria a líder da revolta popular, "des-heroicizandoa"; insere os poemas para interromper a continuidade da narrativa, tornando-os elementos narrativos, e termina por transpor para o palco as caricaturas das figuras políticas da época de forma ridícula, grotesca. Assim, comunica-se com o público de seu tempo, tomando o passado como pretexto, inserindo-o no contexto político contemporâneo, em um momento em que a exaltação do passado e a valorização do campo e das tradições populares e folclóricas eram preconizadas pela ditadura. Parece que o nosso dramaturgo "por acidente" - mas "acidente feliz", como disse Luiz Francisco Rebello - criou uma forma, um sistema, de elaboração da peça que, à primeira vista, parece comungar com o que pretendia o regime. Será, talvez, por isso que o texto e a encenação tenham, em um primeiro momento, conseguido passar pela censura? Tendo em vista que o nível intelectual dos censores não era lá muito elevado - como atestam historiadores, e o próprio Cardoso Pires, que analisaram os processos da censura em Portugal -, não é questão para se descartar.

$\mathrm{Na}$ imutável e longeva ordem do mundo - do mundo português, pelo menos -idealizada por Salazar, não caberia jamais uma arte que viesse a abalar as estruturas. Por isso, Brecht foi proibido de ser representado em Portugal, já que a obra do dramaturgo alemão, nas palavras de Barthes (1984, p.194, grifo do autor), "visa elaborar uma prática do abalo", e o abalo, continua o crítico francês, "é uma re-produção, não uma imitação, mas uma produção defasada, deslocada: que faz barulho". 
Essa prática brechtiana do abalo começa a ser desenvolvida no teatro português a partir de Cardoso Pires, abrindo caminho para que outros dramaturgos seguissem a mesma linha. É o caso de Luís de Sttau Monteiro com Felizmente há luar!, que também fala diretamente para o público de seu tempo.

O que mais nos chama a atenção na peça de Sttau Monteiro é o fato de a personalidade ou personagem "principal" não aparecer jamais em cena. A imagem de Gomes Freire é referida e reverenciada pelo grupo que o defende, ou seja, o povo, e, por outro lado, desprezada pelos governadores do reino, que o condenam.

A ausência física de Gomes Freire na peça de Sttau Monteiro fortalece a figura do general na perspectiva do espectador. O público assiste ao que se passa nos bastidores do Poder, é-lhe apresentada didaticamente a formação dos mecanismos de repressão. O general, então, fica em vias de se tornar um mártir ou um herói, mas também Sttau Monteiro - tal como fez Cardoso Pires com a sua Maria da Fontenão permite que isso aconteça porque ausenta a personagem das cenas. Gomes Freire "nunca aparece, mas está sempre presente". E o povo, que o reverencia, como fica diante dessa ausência, que no contexto da fábula é representada pela prisão do general? A personagem Manuel, "o mais consciente dos populares", tem a explicação: "Mas o general está preso em S. Julião da Barra e nós... estamos presos à nossa miséria, ao nosso medo, à nossa ignorância...". No final da peça-de "clima apoteoticamente trágico" (Barata, 1991)-, Matilde pede ao povo que olhe bem para o clarão da fogueira, é ele a luz redentora que desperta o juízo dos homens para que eles se conscientizem de sua condição de miséria e medo frente à força repressiva do Poder. Diante dessa constatação parece ficar no ar que algo precisa ser feito.

Durante todo o tempo de permanência da ditadura salazarista, era de se notar que o chefe do Conselho pouco 
se expunha, pouco aparecia até mesmo nas festividades e comemorações promovidas pelo regime do qual era o mentor maior. Essa ausência, na verdade, fortalecia ainda mais a imagem de Salazar como homem que se devotava ao trabalho, não tinha vida social, era celibatário, solitário, não participava da vida pública. Ao "suprimir" a figura física do general Gomes Freire da peça, Sttau Monteiro aproxima seu texto do mundo conhecido do espectador, mas logo o torna estranho porque a imagem que vai se formando de Gomes Freire ao longo da peça não é exatamente a do conspirador preterido pelos governadores do reino. Inverte-se a chave em dois sentidos. Primeiro que quem conspira, na verdade, são os governadores do reino - o Poder, pois, e não o antipoder, para usar a designação de Oliveira Barata. Segundo Gomes Freire "não é um santo, é um homem como todos nós" - diz o Antigo Soldado - e tampouco um herói; é apenas um "amigo do povo" e, além disso, ele nem aparece em cena. Gomes Freire é personagem simbólica, na peça e na história, pelo menos na leitura de Sttau Monteiro. Mais que a injustiça que ele sofre, o que é aí enfatizado é a articulação ardilosa do Poder, que se organiza para eliminar qualquer coisa que possa abalar suas estruturas.

Os diálogos dos governadores do reino refletem o fictício mundo português desejado pelo regime: "Temos uma missão a cumprir, uma missão sagrada e penosa: a de conservar no jardim do Senhor este pequeno canteiro português. Enquanto a Europa se desfaz, o nosso povo tem de continuar a ver no céu a Cruz de Ourique"; "esta terra [Portugal] de gente pobre, mas feliz” (Sttau Monteiro, 1980, p.43), diz o Principal Sousa. Os valores exaltados por Salazar são claramente referidos na peça, e por meio deles se define a figura do ditador ou o que ele representa.

Se a peça alegoricamente reflete a imagem de Salazar nos diálogos dos governadores do reino, ela, a imagem, obviamente não é espelhada pela figura simbólica do general, mas 
especificamente pela de D. Miguel Pereira Forjaz: "Sonho com um Portugal próspero e feliz, com um povo simples, bom e confiante, que viva lavrando a terra, com os olhos postos no Senhor" (idem, p.76). As falas de D. Miguel, de fato, conferem-lhe um perfil muito similar ao de Salazar - e aqui apresentamos mais um último exemplo: "Sou um homem de gabinete. Não tenho as qualidades necessárias para falar ao povo... Repugna-me a acção, estaria politicamenteliquidado se tivesse que discutir as minhas ordens" (idem, p.78). A imagem do ditador, enfim, se faz presente alegoricamente, na peça, ao lado dos verdadeiros conspiradores.

A transposição alegórica dos fatos históricos, pretendida por seus autores nas duas peças que aqui estudamos, e a proposta, que o teatro português já vinha desenvolvendo, de concomitantemente pensar o teatro e fazer pensar o público, coadunam com a estética teatral proposta por Brecht. Vemos nas duas peças um grande cuidado com a construção formal do texto, que naquele dado momento era mais para ser lido que para ser encenado, independentemente dos esforços de seus autores, da crítica teatral e dos encenadores. Cardoso Pires e Sttau Monteiro, no entanto, não ficaram presos às técnicas brechtianas, não limitaram sua carpintaria teatral ao que muitos outros viram simplesmente como um modelo formal baseado em projeções, cartazes e indicações para uma personagem falar diretamente ao público, como se esses recursos bastassem para tornar épica a peça que escreviam. A simples utilização da técnica não significa tornar a peça épica no sentido brechtiano, como aponta Mario Vilaça (1966); é preciso vitalidade poética, independentemente da estética.

Roberto Schwarz (1999) declara que o ensinamento que se busca no anti-ilusionismo brechtiano "é mais da ordem da pergunta que da resposta"; diríamos que da ordem da pergunta indireta, isto é, daquela que paira no ar, pois é essa que faz refletir (a pergunta direta, por sua objetividade, 
parece ter já uma resposta "certa" ou esperada). A pergunta que se coloca nas peças dos nossos autores extrapola o enredo das peças de final conhecido - seja por causa do episódio histórico, seja porque o desfecho está implícito no título da obra -; a pergunta está, no fundo, na fábula que expõe as contradições e incoerências humanas; daí advém o questionamento, a dúvida, que estimula a reflexão e, por consequência, define o posicionamento crítico.

As peças de Cardoso Pires e Sttau Monteiro conversam com o seu tempo. Dirigem-se ao público - leitor/espectador - a fim de propor mudanças no teatro e nos rumos da história. 


\section{REFERÊNCIAS BIBLIOGRÁFICAS}

ARENDT, H. Bertolt Brecht (1898-1956). In: Homens em tempos sombrios. Tradução de Denise Bottmann. São Paulo: Cia. das Letras, 1987. p.177-213.

ARNAUT, A. P. S. Post-modernismo no romance português contemporâneo: fios de Ariadne - máscaras de Proteu. Coimbra: Almedina, 2002.

BARATA, J. O. História do teatro português. Lisboa: Universidade Aberta, 1991.

BARTHES, R. O rumor da língua. Tradução de António Gonçalves. Lisboa: Edições 70, 1984.

Diderot, Brecht, Eisenstein. In: Oóbvio e o obtuso. Tradução de Lea Novaes. Rio de Janeiro: Nova fronteira, 1990. p.85-96.

Crítica e verdade. Tradução de Leyla PerroneMoisés. São Paulo: Perspectiva, 1999.

BENJAMIN, W. Tentativas sobre Brecht. Tradução de Jesus Aguirre. Madrid: Taurus, 1987.

BENTLEY, E. A experiência viva do teatro. Tradução de Álvaro Cabral. Rio de Janeiro: Zahar Editores, 1967.

O dramaturgo como pensador: um estudo da dramaturgia nos tempos modernos. Tradução de Ana Zelma Campos. Rio de Janeiro: Civilização Brasileira, 1991. 
BOLLE, W. A linguagem gestual no teatro de Bertolt Brecht. Projekt - Revista da Associação Paulista de Professores de Alemão, São Paulo, n.1, p.26-30, nov. 1986.

BORNHEIM, G. Brecht: a estética do teatro. Rio de Janeiro: Graal, 1992.

BRAGA, T. Gomes Freire. Porto: Lello \& Irmão, 1907.

BRANDÃO, R. Vida e morte de Gomes Freire. Lisboa: Alfa, 1990.

BRECHT, B. Teatro dialético: ensaios. Seleção e introdução de Luiz Carlos Maciel. Rio de Janeiro: Civilização Brasileira, 1967.

Vida de Galileu. Tradução de Roberto Schwarz. São Paulo: Paz e Terra, 1991. A alma boa de Setsuan. Tradução de Geir Campos e Antônio Bulhões. São Paulo: Paz e Terra, 1992.

Poemas: 1913-1956. Tradução de Paulo César de Souza. São Paulo: Ed. 34, 2000.

. Diário de trabalho: 1938-1941. Tradução de Reinaldo Guarany e José Lourenio de Melo. São Paulo: Rocco, 2002, v.1.

Diário de trabalho: 1941-1947. Tradução de Reinaldo Guarany e José Lourenio de Melo. São Paulo: Rocco, 2005, v.2.

Estudos sobre teatro. Tradução de Fiama Pais Brandão. Rio de Janeiro: Nova Fronteira, 2005.

CARDOSO PIRES, J. O render dos heróis. Lisboa: Moraes Editores, 1970.

E agora, José? Lisboa: Moraes Editores, 1977.

O delfim. Rio de Janeiro: Civilização Brasileira, 1983.

CARLSON, M. Teorias do teatro: estudo histórico-crítico dos gregos à atualidade. Tradução de Gilson César Cardoso de Souza. São Paulo: Ed. da Unesp, 1997.

CARVALHO, S. (Org.). Introdução ao teatro dialético: experimentos da Companhia do Latão. São Paulo: Expressão Popular, 2009.

CORREIA, R. "Estranhamento": venturas e desventuras de um conceito estético-teórico. Cadernos de Literatura, Coimbra, n.20, p.15-25, 1985. 
COSTA, H. O render dos heróis pelo Teatro Moderno de Lisboa. Vértice - Revista de Arte e Cultura, Coimbra, n.258, p.228-232, 1965.

CRUZ, D. I. História do teatro português. Lisboa: Editorial Verbo, 2001.

DELILLE, M. M. G. Bertolt Brecht em Portugal antes do 25 de abril de 1974: um capítulo da história da resistência salazarista. Dedalus - Revista Portuguesa de Literatura Comparada, Lisboa, n.1, p.63-88, dez. 1991a.

. (Coord. e pref.) Do pobre B. B. em Portugal: aspectos da recepção de Bertolt Brecht antes e depois do 25 de abril de 1974. Aveiro: Estante, 1991b.

DESUCHÉ, J. La técnica teatral de Bertolt Brecht. Barcelona: Oikos-tau, 1966.

JAMESON, F. O método Brecht. Tradução de Maria Sílvia Betti. Petrópolis: Vozes, 1999.

KOUDELA, I. D. Brecht na pós-modernidade. São Paulo: Perspectiva, 2001.

MAGALDI, S. O texto no teatro. São Paulo: Perspectiva, 2001.

MENDONÇA, F. Para o estudo do teatro em Portugal: 19461966. Assis: Faculdade de Filosofia, Ciências e Letras de Assis, 1971.

OLIVEIRA, F. M. O destino da mimese e a voz do palco: o teatro português moderno. Braga: Angelus Novus, 1997.

OLIVEIRA MARQUES, A. H. de. História de Portugal: das revoluções liberais aos nossos dias. Lisboa: Editorial Presença, 1998. v.III.

OLIVEIRA MARTINS, J. P. de. Portugal contemporâneo. Lisboa: Livro de Antonio Maria Pereira, 1895. Disponível em: http://www.purl.pt/158. Acesso em: 15 maio 2009.

PAVIS, P. Dicionário de teatro. Tradução de J. Guinsburg e Maria Lucia Pereira. São Paulo: Perspectiva, 2007.

PORTELA, A. Cardoso Pires por Cardoso Pires. Lisboa: Publicações Dom Quixote, 1991.

QUADROS, A. Teatro. In: Crítica e verdade: introdução à actual literatura portuguesa. Lisboa: Clássica Editora, 1964. p.199-266. 
REBELLO, L. F. O jogo dos homens: ensaios, crônicas e críticas de teatro. Lisboa: Ática, 1971.

História do teatro português. Lisboa: EuropaAmérica, 1972.

Combate por um teatro de combate. Lisboa: Seara Nova, 1977.

Cem anos de teatro português (1880 - 1980). Porto: Brasília Editora, 1984.

Fragmentos de uma dramaturgia. Lisboa: Imprensa Nacional, Casa da Moeda, 1994.

Breve história do teatro português. Lisboa: EuropaAmérica, 2000.

REDONDO JÚNIOR, J. Pano de ferro: crítica, polêmica, ensaios de crítica teatral. Lisboa: Século, 1955.

Panorama do teatro moderno. Lisboa: Arcádia, 1961.

RIBEIRO, A. S. Ainda acerca do "Estranhamento": novas desventuras de um conceito estético-teórico. Cadernos de Literatura, Coimbra, n.22, p.13-25, 1985.

RODRIGUES, G. A. Breve história da censura literária em Portugal. Lisboa: Instituto de Cultura e Língua Portuguesa, 1980.

RODRIGUES, U. T. Noites de teatro. Lisboa: Ática, 1961. v.1. RODRIGUES, W. Técnicas do distanciamento no teatroépico de Bertolt Brecht. Revista de Letras, Assis, v.13, p.193-209, 1970-1971.

ROSENFELD, A. O mito e o herói no moderno teatro brasileiro. São Paulo: Perspectiva, 1996.

O teatro épico. São Paulo: Perspectiva, 2006.

ROUBINE, J.-J. A linguagem da encenação teatral. Tradução de Yan Michalski. Rio de Janeiro: Jorge Zahar, 1998.

Introdução às grandes teorias do teatro. Tradução de André Telles. Rio de Janeiro: Jorge Zahar, 2003.

SANTOS, G. dos. O espetáculo desvirtuado: o teatro português sob o reinado de Salazar (1933-1968). Lisboa: Editorial Caminho, 2004.

SARAIVA, J. H. História concisa de Portugal. Lisboa: EuropaAmérica, 1988.

SÉRIO, M. Sobre Brecht. Lisboa: Ulmeiro, 1976. 
SCHWARZ, R. Altos e baixos da atualidade de Brecht. In: Sequências brasileiras. São Paulo: Cia. das Letras, 1999. p.113-48.

SIMÕES, J. G. Crítica VI: o teatro contemporâneo(1942-1982). Lisboa: Imprensa Nacional: Casa da Moeda, 2004.

STTAU MONTEIRO, L. de. Felizmente há luar! Lisboa: Ática, 1980.

SZONDI, P. Teoria do drama moderno. Tradução de Luiz Sérgio Repa. São Paulo: Cosac \& Naify, 2001.

TOUCHARD, P.-A. O teatro e a angústia dos homens. Tradução de Pedro Paulo de Sena Madureira e Bruno Palma. São Paulo: Duas Cidades, 1970.

VILAÇA, M. Felizmente há luar!, de Luís de Sttau Monteiro. Vértice - Revista de Arte e Cultura, Coimbra, n.221, p.136-8, fev. 1962.

Comentários a uma tradução de Brecht. Vértice Revista de Arte e Cultura, Coimbra, n.232-233, p.90-3, jan./fev. 1963a.

Panorama do teatro português contemporâneo. Vértice - Revista de Arte e Cultura, Coimbra, n.234-236, p.205-20, mar./maio 1963b.

. Do teatroépico. Vértice - Revista de Arte e Cultura, Coimbra, n.271-272, p.261-81, abr./maio 1966.

WERNECK, M. H. A história do outro lado da cortina: uma leitura da peça $O$ render dos heróis, de José Cardoso Pires. Semear - Revista da Cátedra Padre António Vieira de Estudos Portugueses, Rio de Janeiro, n.11, p.219-41, 2005.

WILLETT, J. O teatro de Brecht. Tradução de Álvaro Cabral.

Rio de Janeiro: Zahar, 1967.

WILLIAMS, R. Uma rejeição à tragédia: Brecht. In:

Tragédia moderna. Tradução de Betina Bischof. São Paulo: Cosac \& Naify, 2002. p.247-64.

\section{Bibliografia complementar}

ARISTÓTELES. Poética. Tradução de Eudoro de Souza. In. Os Pensadores. São Paulo: abril, 1973. p.443-71. 
BALL, D. Para frente para trás: um guia para leitura de peças teatrais. São Paulo: Perspectiva, 1999.

BARRENTO, J. (Org.) Realismo, materialismo, utopia: uma polêmica (1935-1940). Lisboa: Moraes Editores, 1978.

BARRETO, C. (Org.) Estrada Larga. Porto: Tip. Bloco Gráfico, 1959.

BERTHOLD, M. História mundial do teatro. Tradução de Maria Paula Zurawski, J. Guinsburg, Sérgio Coelho e Clóvis Garcia. São Paulo: Perspectiva, 2004.

CARY, L.; RAMOS, J. J. M. (Orgs.) Teatro e vanguarda. Lisboa: Editorial Presença, 1970.

COSTA, I. C. A hora do teatro épico no Brasil. Rio de Janeiro: Paz e Terra, 1996.

ESSLIN, M. Brecht: dos males o menor. Rio de Janeiro: Zahar, 1979.

FARIA, J. R. O teatro na estante. São Paulo: Ateliê Editorial, 1998.

GARCIA, J. M. História de Portugal: uma visão global. Lisboa: Editorial Presença, 1989.

GARCIA, S. Teatro da militância. São Paulo: Perspectiva/ Edusp, 1990.

GIRARD, G.; OUELLET, R.; RIGAULT, C. O universo do teatro. Tradução de Maria Helena Arinto. Coimbra: Almedina, 1980.

GUINSBURG, J. Da cena em cena. São Paulo: Perspectiva, 2001.

HANSEN, J. A. Alegoria: construção e interpretação da metáfora. São Paulo: Hedra; Campinas: Ed. da Unicamp, 2006.

MACHADO, C. E. J. Um capítulo da história da modernidade estética: debate sobre o expressionismo. São Paulo: Ed. da Unesp, 1998.

MASSAUD, M. A literatura portuguesa. São Paulo: Cultrix, 1991.

MATEUS, J. A. O. de A. Do teatro e outras escritas. [Lisboa]: Quimera, 2002.

MEDINA, J. (Org.) História de Portugal Contemporâneo - político e institucional. Lisboa: Universidade Aberta, 1994. 
PASTA JUNIOR, J. A. Trabalho de Brecht: breve introdução ao estudo de uma classicidade. São Paulo: Ática, 1986.

PEIXOTO, F. Brecht: uma introdução ao teatro dialético. Rio de Janeiro: Paz e Terra, 1981.

Portugal: o espaço do possível? In: Teatro em movimento. São Paulo: Hucitec, 1989. p.104-5.

Brecht: vida e obra. São Paulo: Paz e Terra, 1991.

PETROV, P. O realismo na ficção de José Cardoso Pires e Rubem Fonseca. Miraflores: Difel 82, 2000.

PICCHIO, L. S. História do teatro português. Lisboa: Portugália, 1969.

PORTO, C.; MENEZES, S. T. 10 anos de teatro e cinema em Portugal: 1974-1984. Lisboa: Editorial Caminho, 1985.

POSADA, F. Lukács, Brecht e a situação atual do realismo socialista. Tradução de A. Veiga Fialho. Rio de Janeiro: Civilização Brasileira, 1970.

SARTINGEN, K. Brecht no teatro brasileiro. Tradução de José Pedro Antunes. São Paulo: Hucitec, 1998.

SECCO, L. A Revolução dos Cravos. São Paulo: Alameda, 2004.

TENGARRINHA, J. (Org.) História de Portugal. Bauru: Edusc; São Paulo: Ed. da Unesp; Portugal: Instituto Camões, 2001.

TENSCHERT, J. A máscara no Beliner Ensemble. VérticeRevista de Arte e Cultura, Coimbra, n.226-227, p.411-4, jul./ago. 1962.

TORRES, A. P. Sociologia e significado no mundo romanesco de José Cardoso Pires. In: Romance: o mundo em equação. Lisboa, Portugália, 1967.

UBERSFELD, A. Para ler o teatro. Tradução de José Simões. São Paulo: Perspectiva, 2005.

WAGNER, F. Teoria e técnica teatral. Coimbra: Almedina, 1978. 


\section{Traços ÉPICO-BRECHTIANOS NA DRAMATURGIA PORTUGUESA}


CONSELHO EDITORIAL ACADÊMICO

Responsável pela publicação desta obra

Alcides Cardoso dos Santos

João Batista Toledo Prado

Márcia Valéria Zamboni Gobbi 


\section{MÁRCIA REGINA RODRIGUES}

\section{TraÇOS \\ ÉPICO-BRECHTIANOS \\ NA DRAMATURGIA PORTUGUESA \\ O RENDER DOS HERÓIS, de Cardoso Pires, \\ e FELIZMENTE HÁ LUAR!, de Sttau Monteiro}

CULTURA

$\frac{\text { ACADÊMICA }}{\mathcal{E} \text { diton } a}$ 


\section{(C) 2010 Editora UNESP}

\section{Cultura Acadêmica}

Praça da Sé, 108

01001-900 - São Paulo - SP

Tel.: (0xx11) 3242-7171

Fax: (0xx11) 3242-7172

www.editoraunesp.com.br

feu@editora.unesp.br

CIP - Brasil. Catalogação na fonte

Sindicato Nacional dos Editores de Livros, RJ

R614t

Rodrigues, Márcia Regina

Traços épico-brechtianos na dramaturgia portuguesa : 0 render dos heróis, de Cardoso Pires, e Felizmente há luar!, de Sttau Monteiro / Márcia Regina Rodrigues. - São Paulo : Cultura Acadêmica, 2010.

Inclui bibliografia

ISBN 978-85-7983-114-0

1. Pires, José Cardoso, 1925-1998. O render dos heróis. 2. Monteiro, Luís de Sttau, 1926-1993. Felizmente há luar!. 3. Brecht, Bertolt, 1898-1956 - Influência. 4. Teatro português (Literatura) - História e crítica. 5. Teatro e sociedade - Portugal. I. Título. II. Título: O render dos heróis, de Cardoso Pires. III. Título: Felizmente há luar!, de Sttau Monteiro.

10-0097.

CDD: 869.2

CDU: 821.134.3-2

Este livro é publicado pelo Programa de Publicações Digitais da Pró- Reitoria de Pós-Graduação da Universidade Estadual Paulista "Júlio de Mesquita Filho" (UNESP)

Editora afiliada:

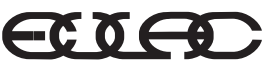

Asociación de Editoriales Universitarias de América Latina y el Caribe

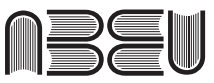

Associação Brasileira de Editoras Universitárias 
Agradeço à professora Renata Soares Junqueira pela dedicada leitura crítica que fez de meus textos e pela orientação do caminho; a Arthur Autran pelas palavras de estímulo; aos professores Litian Lopondo, José Pedro Antunes e Márcia Valéria Zamboni Gobbi; à Coordenação de Aperfeiçoamento de Pessoal de Nivel Superior (Capes) pela bolsa concedida para a viabilização de minha pesquisa. 
O homem não é regido por forças insondáveis que para sempre lhe determinam a situação metafísica. Depende, ao contrário, da situação histórica que, por sua vez, pode ser transformada.

(Anatol Rosenfeld 2006, p.150) 


\section{SuMÁrio}

Introdução 11

1 A situação do teatro português na década de $1960 \quad 17$

2 Algumas considerações sobre o teatro épico de Brecht 43

3 O render dos heróis, a fábula histórica de Cardoso Pires 79

4 Felizmente há luar!, a fábula histórica de Sttau Monteiro 105

Considerações finais 129

Referências bibliográficas 141

Bibliografia complementar 145 


\section{INTRODUÇÃO}

Mais do que no romance, e ainda mais que na poesia, o teatro adere à realidade imediata, que frequentemente o submerge. Isso explica, por um lado, a proliferação das obras de teatro, e por outro o número relativamente diminuto das que logram transcender esse circunstancialismo que lhes está na origem e cuja aceitação é, no entanto, uma condição sine qua non

da sua própria existência teatral. (Rebello, 1984, p.10)

Depois da Segunda Guerra, o teatro português abre um novo capítulo em sua história com a criação de várias companhias, com o surgimento de novos dramaturgos e com a busca de uma estética teatral que respondesse aos anseios eàs inquietações dos artistas frente à realidade. Até a Revolução dos Cravos (25 de abril de 1974), entretanto, vamos observar um fenômeno recorrente: muitas peças foram escritas e pouquíssimas delas foram encenadas. Impedidas de subirem 
à cena pela censura instituída pelo governo ditatorial de António de Oliveira Salazar, ${ }^{1}$ um número considerável de obras teatrais chegou a público apenas em forma de livro. O teatro em Portugal era mais lido que encenado. Um "divórcio”, como bem definiu Luiz Francisco Rebello (1972), acentuava-se entre dramaturgia e encenação. Devido a esse particular, o teatro português desse período, como analisa Fernando Mendonça (1971), preocupava-se principalmente com o texto, valorizando a palavra, o diálogo cheio de conteúdo, já que o dramaturgo, ao escrever, sabia que pouca chance teria de ver sua peça encenada.

No que tange à questão estética, vemos, na maior parte das peças, a rejeição das formas naturalistas e a valorização do anti-ilusionismo como características fundamentais e princípios que levaram os dramaturgos à elaboração, construção e utilização de recursos cênicos múltiplos, que, muitas vezes, acabavam por constituir um notável hibridismo na linguagem cênica (Mendonça, 1971).

É principalmente nas duas últimas décadas que antecedem a Revolução dos Cravos que o teatro integra a seus temas e formas uma preocupação em abrir o caminho para a reflexão crítica sobre a realidade, denunciando as injustiças sociais e preconizando um posicionamento conscientemente político do público. Nesse contexto, o teatro épico - desenvolvido, praticado e teorizado pelo dramaturgo alemão

1 Em 28 de maio de 1926 tem início a ditadura portuguesa, decorrente do golpe militar que pôs fim à Primeira República. António de Oliveira Salazar (1889-1970) é designado ministro das Finanças em 1928; em 1932, é nomeado chefe do Conselho de Ministros, oficializando o Estado Novo em 1933, quando promulga a legislação da censura e a criação do Secretariado de Propaganda Nacional. Por problemas de saúde, Salazar é afastado do poder em 1968, sendo nomeado Marcelo Caetano o seu sucessor. Salazar morre em 1970 sem saber que não governava mais o país. Depois de 48 anos de ditadura, a Revolução dos Cravos, em 25 de abril de 1974, põe fim ao regime, instaurando a democracia em Portugal. 
Bertolt Brecht (1889-1956)-, cujo principal objetivo é o de "possibilitar ao espectador uma crítica fecunda, dentro de uma perspectiva social” (Brecht, 2005, p.97), tornava-se uma "novidade [que] parecia dar resposta a algumas das perplexidades dos dramaturgos portugueses" (Barata, 1991, p.356). Assim, os dramaturgos e os demais artistas do teatro português começaram a entrar em contato com a dramaturgia e a teoria do teatro épico brechtiano, obtendo conhecimento dos pressupostos teóricos do dramaturgo alemão por meio das traduções francesas ou inglesas que circulavam em Portugal e de estadas na França, Inglaterra ou Alemanha, onde assistiam aos espetáculos. ${ }^{2}$

Em finais dos anos de 1950 e na década de 1960, a criação de novas companhias de teatro e o surgimento de novos dramaturgos foram fatores que contribuíram para aumentar a atividade teatral e também o interesse por Brecht, cuja obra dramática começava a ser traduzida para o português, ainda que de forma intermitente e dispersa. Mas as encenações de peças brechtianas - com uma ou outra exceção, como veremos - foram totalmente proibidas nos palcos portugueses pela comissão de censura do Estado Novo. Nesse período, o regime salazarista tornava-se ainda mais repressor, e "proibir o teatro, como instrumento de conscientização e promoção sociocultural, como meio de desalienação e desmistificação das mais vastas camadas populacionais, era efectivamente a aspiração secreta do regime" (Rebello, 1977, p.39).

É no teatro de 1960, caracterizado pela intensa produção dramatúrgica sob a mira da censura salazarista, que incide nosso estudo. Dessa dramaturgia publicada interessa-nos

2 O espetáculo $\mathrm{O}$ círculo de giz caucasiano, com direção do próprio Brecht, apresentado no Teatro Sarah Bernhardt, no II Festival de Arte Dramática de Paris, em 1955, foi marcante para os atores portugueses do Teatro Nacional que também participaram do festival (Dellile, 1991a). 
exclusivamente a de cariz brechtiano. Sendo assim, elegemos como objeto de análise duas peças consideradas pela crítica os primeiros frutos da perspectiva brechtiana de teatro épico na dramaturgia portuguesa: O render dos heróis (1960), de José Cardoso Pires (1925-1998), e Felizmente há luar! (1961), de Luís de Sttau Monteiro (1926-1993).

O render dos heróis - peça em "três partes e um epílogo concluído em apoteose grotesca", como a define seu autor - trata da revolta popular, ocorrida em 1846, denominada "Maria da Fonte", nome atribuído à mulher considerada a instigadora dos motins iniciais da revolta. Felizmente, há luar! - peça em dois atos - narra a trajetória do general Gomes Freire de Andrade, sentenciado à morte, em 1817 , pelos governadores do reino, por ter sido considerado o líder da Revolução Liberal. Tanto $O$ render dos heróis como Felizmente há luar! apresentam fatos históricos remanescentes ou antecedentes da Revolução Liberal de 1820, com o claro objetivo de levar o espectador a uma análise crítica da situação político-social do Portugal da década de 1960. Da mesma forma, a escolha estética dos dramaturgos vincula-se à preocupação de criar artisticamente formas de crítica e de resistência ao regime político vigente no país.

A peça de Cardoso Pires foi encenada pela primeira vez em 1965, mas logo sofreu os processos da censura, ficando pouco tempo em cartaz em Lisboa. Felizmente há luar! não foi autorizada a ser representada, tendo sido encenada em Paris, em 1969, e em Portugal somente em 1978, depois da Revolução dos Cravos. Foram, portanto, obras dramáticas que estabeleceram a comunicação com o público primeiramente, e durante um bom tempo, mais por meio da leitura. Por isso é possível afirmar que essas duas peças, pelo menos até 1974 , foram mais lidas que encenadas. Daí seu público ser, à época, predominantemente constituído por leitores e não por espectadores. 
Para pensar o teatro português do referido período e analisar essas duas peças, consideramos os modos de aplicação da censura (aos textos e aos espetáculos), praticados pela ditadura de Oliveira Salazar e de seu sucessor, Marcelo Caetano, e o teatro épico brechtiano como escolha estética dos dramaturgos que o adotaram como uma possibilidade de proporcionar ao espectador a oportunidade de reflexão sobre seu tempo. Primeiro apresentamos uma breve descrição da situação do teatro português na década de 1960, enfatizando a tensa relação da arte dramática com a censura. Em seguida, algumas considerações acerca do teatro épico de Brecht, já que é para essa estética que se volta o interesse de parte dos dramaturgos portugueses desse período. Da obra teórica de Brecht salientamos o elemento caracterizador do teatro épico brechtiano, o efeito de distanciamento, a partir de dois aspectos: a encenação épica e os modos de teatralização - isto é, de o teatro mostrar-se teatro. O primeiro aspecto refere-se mais especificamente às recomendações de Brecht sobre as técnicas utilizadas para a atuação do ator; o segundo, aos recursos empregados para a constituição da cena dita épica.

O principal objetivo deste estudo é apontar, descrever e analisar as formas de transposição dos pressupostos brechtianos de teatro em $O$ render dos heróis, de José Cardoso Pires, e Felizmente há luar!, de Luís de Sttau Monteiro, e mostrar a relação dessas peças com o período anterior à Revolução de 25 de abril, especificamente na década de 1960 , marcada pelos processos de aplicação da censura.

A matriz brechtiana em $O$ render dos heróis e em Felizmente há luar!, além de ser a estética responsável por uma tentativa de inovação nas formas dramáticas praticadas em Portugal, confirma a preocupação dos autores com a expressão de um posicionamento crítico perante a realidade, com os rumos da dramaturgia e com o papel do dramaturgo em seu tempo e lugar. 


\title{
1 \\ A SITUAÇÃO DO TEATRO PORTUGUÊS NA DÉCADA DE 1960
}

\author{
Apesar dos obstáculos que, \\ absurdamente, impedem as suas \\ obras de cumprir o normal destino de \\ todas as criações dramáticas, \\ que é serem interpretadas num palco, \\ por actores, diante de um público, \\ os autores portugueses continuam \\ inevitavelmente a escrever para \\ o teatro. E essa teimosa persistência \\ é, sem dúvida, o mais seguro penhor \\ de que, nas suas mãos, a gloriosa \\ herança de Gil Vicente, de Ferreira, \\ do "Judeu", de Garrett, \\ não se extinguirá. \\ (Rebello, 1972, p.119)
}

Os críticos e historiadores da arte dramática portuguesa, ao avaliarem o desenvolvimento do teatro - como um todo ou mais especificamente da dramaturgia -, afirmam o "ressurgimento" (Vilaça, 1963b), a "evolução” (Rebello, 1972), um "movimento ascensional” (Rodrigues, 1961) do teatro português após a Segunda Guerra, principalmente na década de 1960. Até no olhar analítico mais distanciado 
no tempo há um reconhecimento, ainda que com emprego de termos menos entusiasmados, de um "desenvolvimento global e harmonioso" da atividade teatral portuguesa posterior a 1945 (Barata, 2001). Assim, o teatro, mesmo com a censura a estorvar-lhe o caminho, como veremos adiante, consegue não apenas resistir, mas manter suas criações dramatúrgicas em sintonia com as inovações estéticas do século XX, embora com algum natural atraso.

Em ensaio intitulado Panorama do teatro português contemporâneo, MárioVilaça(1963b, p.219), que acompanhava no calor da hora a atividade teatral, afirma acreditar no ressurgimento da literatura dramática em seu país devido ao fato de as editoras, desde 1958, "arriscarem-se" mais a editar teatro, e de ter aumentado consideravelmente o número de autores de peças teatrais, "não porque tudo o que se tem publicado seja bom. Mas, sim, porque já alguma coisa de bom apareceu, pelo menos bastante bom". Por outro lado, António Quadros (1964, p.204, grifo nosso) aponta, na produção teatral contemporânea, a falta de dramaturgos autênticos e critica a imitação de modelos europeus de teatro: "Arremedar o teatro de Paris não é criar o teatro português, nem, afinal, teatro que como tal possa ser considerado", mas admite que "Raul Brandão vai deixando de estar isolado na nossa nascente dramaturgia". Fernando Mendonça (1971, p.16), por sua vez, acredita que o teatro assume, pelo menos em parte, a mesma função de intervenção social que o romance e o conto neorrealistas desempenhavam na década de 1940, compartilhando a mesma ideia de que se trata de um fértil momento para a produção da dramaturgia:

O decênio de 1960 é o de maior florescimento teatral, teatro escrito, entenda-se. Uma plêiade de jovens escritores aventura-se decididamente a este meio de comunicação e produz (e está produzindo) um quantitativo surpreendente de peças que, se nem sempre apresentam um elevado nível 
dramático (ou épico), até porque são, de maneira geral, autores muito jovens, têm, contudo, o mérito de manter viva a literatura dramática em Portugal.

Vários novos autores nasciam na vida teatral portuguesa na década de 1960. Alguns deles eram já experientes romancistas e participavam pela primeira vez da criação teatral, ${ }^{1}$ muitos traziam ideias novas sobre a dramaturgia e a encenação captadas em outros países. Esse surto de autores certamente favoreceu a possibilidade de experimentação; assim, nos anos de 1960, as experiências estético-teatrais proliferavam em Portugal.

Muito da dramaturgia portuguesa da década de 1960 compartilha o mesmo princípio sustentado pela companhia do Teatro-Estúdio do Salitre, ${ }^{2}$ criada em 1946, que representou uma primeira tentativa de atualização do teatro em Portugal logo depois do fim da Segunda Guerra e "deu consciência à necessidade de libertar a cena portuguesa da hegemonia naturalista" (Rebello, 1972, p.107) do drama burguês.

A estética naturalista, como se sabe, visa objetivamente o efeito de ilusão de realidade no palco, de modo a trazer para a cena personagens que "vivem" o papel que desempenham, por meio de uma linguagem muito próxima da cotidiana, em cenários que procuram reconstituir a realidade. O espetáculo naturalista fornece ao público a sensação - ou a ilusão - de

1 Tanto Cardoso Pires como Sttau Monteiro estrearam na literatura dramática com as peças aqui em apreço. Antes disso, os dois escritores haviam publicado romances e contos. De Cardoso Pires destacamos Os caminheiros e outros contos (1949) e $O$ anjo ancorado (novela de 1958); e de Sttau Monteiro, Um homem não chora (1960) e Angústia para o jantar (1961).

2 Sob a direção de Luiz Francisco Rebello, Gino Saviotti e Vasco Mendonça Alves, o Teatro-Estúdio do Salitre foi instalado em uma sala do Instituto de Cultura Italiana, que possuía um diminuto palco, característica que deu ao grupo a designação de microteatro. 
estar diante de um acontecimento real, esquecendo-se, durante o tempo da encenação a que assiste, de que está, na verdade, diante de um acontecimento ficcional. Era isso que certa parcela dos artistas do teatro português começava a evitar. Assim, paulatinamente, assistia-se, "de peça para peça, a um distanciamento cada vez maior das estruturas e da linguagem tradicionais do teatro naturalista-realista" (idem, 1984, p.26).

Luiz Francisco Rebello aponta que "o experimentalismo, as preocupações sociais e a reflexão existencial" caracterizaram o teatro que se escreveu na primeira metade do período compreendido entre o fim da Segunda Guerra e o fim do regime salazarista. Do final dos anos de 1950 até 1974, "o teatro do absurdo e o teatro épico" interessaram sobremaneira os dramaturgos portugueses, pois

o recurso a uma linguagem crítica, a personagens e situações abstractas, que deformavam até ao absurdo a realidade circunstante, por um lado, e por outro a transposição do presente para factos e figuras exemplares do passado histórico, ou destas para aquele, eram as várias tentativas de dizer-se o que, directamente, a censura não consentia que se dissesse. (idem, p.25)

Além da integração de formas dramatúrgicas do teatro épico ou do teatro do absurdo no referido período, contribuiu para a definição de um "largo movimento de evolução contemporânea" do teatro, como constata Duarte Ivo Cruz (2001, p. 303), a constância das seguintes características:

[...] concentração num temário de análise e crítica social muito marcado e politicamente empenhado; tentativa de renovação das expressões cênicas e do espetáculo; visão cultural do teatro como um todo; certa irregularidade a nível de profissionalismo, com grande ênfase dada ao experimentalismo e à descentralização por via profissional e amadora; irregularidade da frequência de público, com uma clara passagem do 
teatro comercial, bom ou mau, para o teatro experimental ou culturalmente exigente, o que teve como efeito a médio prazo o desaparecimento da revista.

A incidência de temas de análise e crítica social e a busca por uma inovação dramatúrgica e cênica anti-ilusionista vão se filiar quase que naturalmente à "lição" de Brecht, ou seja, aos princípios norteadores do teatro épico brechtiano, que, como veremos, opõe-se ao teatro naturalista, criticando esse tipo de teatro em que o espectador se deixa levar pela cena apresentada, identificando-se com ela, sem proceder a qualquer julgamento ou reflexão.

A "fase nova de ressurgimento" e de "assinalável progresso" foram as características apontadas por MárioVilaça (1963b) na dramaturgia contemporânea, muito embora o ensaísta reconhecesse que as peças esperavam pela representação no palco.

O que suprimia a dimensão cênica das peças escritas não era a falta de grupos interessados em encená-las. São registradas no referido período novas companhias teatrais, entre elas: Teatro Moderno de Lisboa (TML, 1961), Teatro Estúdio de Lisboa (TEL, 1964), Teatro do Instituto Superior Técnico (IST, 1964), Grupo 4 (1967), Teatro Experimental de Cascais (TEC, 1965). E continuavam em atividade as principais companhias criadas nos anos de 1950: Teatro Experimental do Porto (TEP, 1952, tornando-se profissional em 1957), Círculo de Iniciação Teatral da Academia de Coimbra (CITAC, 1956), Cênico de Direito (Teatro da Associação Acadêmica da Faculdade de Direito, 1954). A maioria dessas companhias de teatro teve sua origem em grupos formados na universidade e elas tinham características comuns: buscavam efetiva participação do público; objetivavam levar o espectador à análise e à crítica do contexto político-social e, principalmente, reconheciam o teatro como instrumento de intervenção e de luta política 
e cultural. Graça dos Santos (2004, p.327) nos fornece uma descrição precisa dos espectadores desses teatros:

Graças ao teatro universitário (em particular o CITACe o Cênico de Direito), surge uma nova maneira de ser espectador. Era uma assistência entusiástica e jovem, proveniente sobretudo dos meios universitários. Não eram espectadores passivos e queriam compreender o fenômeno teatral e os seus diferentes processos. Na sua maioria tinham nascido sob o salazarismo, e só tinham conhecido um Portugal em que qualquer ideia original era sufocada pela censura, qualquer comportamento não conforme aos modelos impostos pelo Estado Novo era silenciado, mas tinham uma enorme sede de ideias novas, de par da exigência de uma universidade livre.

Nesse contexto em que o teatro é vigiado de perto pelos "conservadores salazarófilos" - para usar a expressão da mesma autora acima citada -, surgem, a partir de 1960, os dramas narrativos de tema histórico, adeptos do registro épico brechtiano, uns mais outros menos bem-sucedidos: $O$ render dos heróis (1960), de José Cardoso Pires; Felizmente há luar! (1961), de Luís de Sttau Monteiro; Bocage (1965), de Romeu Correia; O judeu (1966), de Bernardo Santareno; Bocage alma sem mundo (1967), de Luzia Maria Martins; A outra morte de Inês (1968), de Fernando Luso Soares; Quem move as árvores (1970), de Fiama Pais Brandão; Antonio Vieira (1973), de Fernando Luso Soares; Legenda do cidadão Miguel Lino (1973), de Miguel Franco.

A produção dramatúrgica, a publicação das peças teatrais, as experimentações e novas formas de encenação criadas e desenvolvidas pelas companhias de teatro que surgiam, tudo sofria a constante asfixia tanto da mão pesada da censura sobre os textos, quanto do olhar vigilante dos censores sobre os grupos de teatro e suas representações.

Diante disso, é importante vincular aos dados e características que aqui apontamos as formas de repressão 
praticadas pela censura salazarista, que impôs sua marca na história do teatro português.

\section{O teatro sob a mira da censura}

No extremamente longo e tenso período da ditadura em Portugal, as práticas da comissão de censura ${ }^{3}$ impuseram terror e medo aos escritores, intelectuais, dramaturgos e jornalistas, pela constante proibição e apreensão de obras e pela ameaça de prisão de seus autores, impedindo muitas vezes "que os meios de comunicação social mencionassem o título de obras proibidas e o nome do seu autor" (Rodrigues, 1980, p.77). A censura evitava esclarecer ou fundamentar uma decisão publicamente, e quando era necessário fazê-lo era breve e objetiva, impondo a redação da informação a ser publicada. Um telegrama telefonado da Comissão do Exame Prévio do Porto para a imprensa, reproduzido por Graça dos Santos (1980, p.75), ilustra bem o que afirmamos:

Foi proibida uma peça de teatro, adaptação de Correia Alves, do Arco de Sant 'Ana, no TEP (Teatro Experimental do Porto). Não dizer que foi proibida. Pode, no entanto, dizer-se que já não vai à cena. Capitão Correia de Barros.

O teatro foi um dos grandes alvos da censura, que reprimiu a produção de peças teatrais e proibiu a representação, nos palcos, de textos de autores portugueses ${ }^{4}$ e estrangeiros.

3 A partir de 1933, a censura passou a ser exercida por comissões. A Comissão de Censura de Lisboa exercia o papel de Comissão Central. A Comissão de Examee Classificação dos espetáculos, que tinha o seu presidente nomeado por Salazar, passou a avaliar e a classificar as peças de teatro, autorizando-as por inteiro ou com corte, ou proibindo-as.

4 Rebello (1984, p.13) fornece-nos os números: "É significativo que, das 79 peças compendiadas entre 1926 e 1974 e aqui [no seu livro] resumidas, 27 - cerca de 35\% - tenham sido banidas pela censura, 
O "lápis azul" 5 dos censores rasurava as palavras, frases e falas das peças - era, pois, a marca concreta da censura nos textos. Nos teatros, os censores se faziam presentes nas primeiras fileiras da plateia.

A ditadura salazarista promoveu em Portugal o conformismo, a apatia, a imutabilidade diante da realidade e a censura impôs o silêncio dentro e fora do país:

Como primeiro objectivo [a censura salazarista] procurou confinar as cidadelas culturais e todo o país, todo, a um isolacionismo que lhe facilitasse a imposição violenta das suas regras. Em segundo alcance pretendeu, e com algum êxito, elaborar em silêncio fechado certas máscaras contemporâneas para publicidade exterior. Seria, numa palavra, o "petit dictateur" que à custa do segredo cultiva as impunidades do abuso e exporta uma imagem tolerável no convívio internacional. Silêncio, portanto, no exterior. Pax intra muros. (Cardoso Pires, 1977, p.200)

Salazar, que comumente costumava subestimar a inteligência dos cidadãos (Rodrigues, 1980), entendia a censura como um "corretivo necessário" à organização da sociedade, como explica José Cardoso Pires em uma entrevista a Artur Portela (1991, p.38): "Salazar pretendia radicar, por exemplo, a censura como um hábito social, uma prática familiar de dissuasão, por assim dizer. Chamava-lhe resignadamente 'um mal necessário', como toda a gente sabe".

Na comparação entre a censura praticada durante o regime de Salazar e a aplicada pelo nazismo de Hitler, Graça dos Santos (2004, p.73) faz uma síntese esclarecedora:

das quais apenas 3 vieram a ser mais tarde autorizadas e outras tantas proibidas após a primeira série de representações".

5 Os censores suprimiam palavras ou frases inteiras riscando-as por completo com cor azul, daí a expressão "lápis azul da censura". Às vezes, apareciam comentários, geralmente em letra ilegível, nas margens dos textos, o que impossibilitava saber por quais motivos a obra havia sido censurada. 
As medidas de depuração e de destruição das obras literárias ou artísticas são, para as autoridades nazis, pretexto para grandes operações publicitárias em que o terror, o medo são exibidos. Essa é uma diferença essencial em relação ao salazarismo, que prefere confiscar discretamente as obras consideradas indesejáveis. Os esforços vão mais no sentido de abafar as resistências, tentando tudo para que não se manifestem [...]. Trata-se de evitar para não defrontar, mantendo para isso uma ilusão de harmonia, de um povo sereno e tranquilo.

Analisando a censura sofrida pelo teatro durante o Estado Novo, Luiz Francisco Rebello (1977) aponta três tipos: censura ideológica, censura econômica e censura geográfica. A proibição de espetáculos e textos teatrais estrangeiros ou portugueses era a arma do poder ditatorial para impedir o acesso do público àquilo que, para a comissão de censura, era "perigoso", "subversivo" ou simplesmente "suspeito"; assim, a arte coletiva por natureza, que é o teatro, sofria a censura ideológica. Os espetáculos escolhidos pelos empresários para lhes destinar patrocínio eram aqueles que agradavam ao público burguês que podia pagar o preço dos ingressos, constituindo-se, neste caso, uma forma de censura econômica. Já a censura geográfica se define, segundo Rebello (idem, p.26), pelo fato de a atividade teatral se concentrar quase que exclusivamente na capital do país, ou seja, ficava limitada "a cerca de nove décimos da população a possibilidade de assistir a espetáculos teatrais (possibilidade teórica, já que na prática a reduziam aos outros condicionamentos antes referidos)".

$\mathrm{Na}$ ditadura de Salazar, a aplicação da censura empregava ainda as formas preventiva e repressiva (Santos, 2004) a todo material de comunicação a ser veiculado em Portugal. As tipografias, por exemplo, antes de pôr um livro em circulação, eram obrigadas a submetê-lo às autoridades da segurança pública, que tinham poderes para fechar as 
gráficas que imprimissem material suspeito de "perturbar a segurança pública". ${ }^{6}$ No caso do teatro, o procedimento da censura era complexo. Escrita a peça, o autor ou grupo de teatro deveria submeter o texto ao exame do censor, que autorizava, autorizava com cortes ou proibia a obra. Comentam os escritores que muitas vezes os cortes feitos pelo famoso lápis azul do censor eram tantos que o texto ficava horrivelmente mutilado, tornando a peça irrepresentável. Se vencida a primeira etapa, ou seja, tendo o texto o carimbo "Visado pela Comissão de Censura", vinha a segunda: "ensaio de censura", que consistia em uma apresentação da peça no palco - com todo o figurino, a música, o cenário, a iluminação - para a supervisão do censor. Graça dos Santos (idem, p.273) registra o depoimento do encenador Fernando Gusmão, que descreve o ensaio de censura como "controlado por mais de dez censores que, cúmulo do ridículo, seguiam o texto com lanternas de bolso a fim de verificar a conformidade do texto dito com o texto visado pela censura". Nessa segunda etapa, também poderia haver "correções" ditadas pelo censor; então lá ia o grupo teatral fazer, em novos ensaios, as modificações exigidas, o que levava ao adiamento da estreia do espetáculo - e tempo e dinheiro eram perdidos. O sentimento que prevalecia nos autores era o do medo, além do estresse total. Por meio de suas práticas, a Comissão de Censura declarava aos artistas o domínio do poder político sobre o social:

Retrair o editor e apagar a presença social do escritor português eram dois lances do mesmo jogo que a Censura desenvolvia metódica e sistematicamente. Num conjunto de operações aparentemente dispersas, quer dificultando o apoio da imprensa ao autor, quer actuando directamente so-

6 Semelhante é o caso dos periódicos. A apresentação de provas dos jornais já paginados era obrigatória, sendo necessário fazer as alterações exigidas pela comissão em curto espaço de tempo. 
bre as editoras, quer ainda inspirando pressões indirectas por intermédio de vários ministérios, procurava-se isolar o autor nacional, tornando-o inconveniente às instituições privadas, dificultoso para a indústria do livro e socialmente inoperante ou irrepresentativo. (Cardoso Pires, 1977, p.231-2)

Os processos da censura - cujo principal objetivo era o domínio da comunicação -, além de desgastantes e humilhantes, constituíam uma ameaça para a obra e para o seu autor. A peça poderia sofrer algum tipo de mutilação ou o texto ser totalmente proibido. O dramaturgo corria o risco de ser preso, sem de fato saber o porquê, pois a dita comissão era desprovida de critérios, sendo a subjetividade do censor o que guiava sua avaliação de textos e espetáculos:

\section{Critérios?}

Não é necessário adiantar muitas explicações ou aduzir exemplos. Fundamentalmente, interessava [à comissão de censura] detectar o que poderia ser menos consonante com os valores que se tinham como únicos e, por isso mesmo, susceptíveis de "pôr em risco a segurança e a tranquilidade do país”. (Barata, 1991, p.353)

O censor, devido à deficiência de sua formação cultural (Cardoso Pires, 1977), quando não entendia uma sentença ou onde achava ter algo suspeito, cortava sem se preocupar com a consequência da mutilação feita nos textos.

Na década de 1960, a censura praticada pelo Estado Novo tornou-se ainda mais intensa: o Centro Português do Instituto Internacional de Teatro foi considerado ilegal, a Sociedade Portuguesa de Escritores foi extinta, ${ }^{7}$ a peça

7 Em nome da Sociedade Portuguesa de Escritores, um júri, formado pelos escritores Alexandre Pinheiro Torres, Augusto Abelaira, João Gaspar Simões, Manuel da Fonseca e Fernando Botelho, concedeu o prêmio da novela ao livro Luuanda, do escritor José Luandino Vieira, 
O motim, de Miguel Franco, foi impedida de continuar em cena - exemplo claro de censura repressiva - depois de apenas cinco apresentações do espetáculo, o que resultou em protestos e abaixo-assinados ${ }^{8}$ de intelectuais e artistas, repudiando o silêncio ao qual o teatro português estava sendo condenado.

Além da proibição de espetáculos, do impedimento da representação de determinadas peças nacionais, o público português também foi privado da encenação de peças de autores estrangeiros. Entre as dramaturgias estrangeiras proibidas deencenação nos palcos portugueses encontramos todas as peças de Bertolt Brecht, Jean-Paul Sartre, ${ }^{9}$ Peter Weiss, parte da produção de Jean Anouilh, Fernando Arrabal, Friedrich Dürrenmatt, Max Frisch, Eugène Ionesco, Alfred Jarry, Sean O'Casey, Erwin Piscator, Alfonso Sastree ainda especificamente as peças Julio César (William Shakespeare) e A mandrágora (Nicolau Maquiavel).

De acordo com Luiz Francisco Rebello (1977), mesmo com a liberação para a encenação de algumas peças portuguesas (O pecado de João Agonia, de Bernardo Santareno; As mãos de Abraão Zacut, de Luís de Sttau Monteiro; Forja, de Alves Redol) e de outras estrangeiras (Quem tem medo de Virginia Woolf?, de Edward Albee) na chamada Primavera Marcelista, a Comissão de Censura apenas

que se encontrava preso em cumprimento de uma sentença de 14 anos por ter lutado pela independência de Angola. Em represália, a sede da sociedade foi saqueada e depois extinta e os membros do júri interrogados pela Polícia Política.

8 O "Protesto contra a proibição da permanência nos palcos, em 1965, da peça O motim”, dirigido ao Ministro da Educação, é integralmente reproduzido por Rebello (1977, p.161-4).

9 Exceção para as peças A Respeitosa - no Brasil, A prostituta respeitosa -, de Jean-Paul Sartre, e A alma boa de Setsuan, de Brecht, que "só foram consentidas [em 1960] a uma companhia estrangeira (a companhia brasileira de que era directora e actriz Maria Della Costa)" (idem, p.30). 
mudou de nome os seus órgãos constituintes, mantendo as suas práticas e processos:

Com a subida de Marcelo Caetano ao poder [1968], o regime afivela uma nova máscara (sorridente) - embora o rosto permanecesse imutável. Tal como a polícia política e a União Nacional mudaram de nome $e^{10}$ e as colónias passaram a ser "províncias ultramarinas", a censura à imprensa crismou-se de "exame prévio" e a Comissão de censura aos espetáculos de "exame de classificação". (Rebello, 1977, p.31)

Outros escritores tinham igual percepção sobre o sucessor de Salazar: "O consulado de Marcelo Caetano procurava adaptar a subdoutrina de Salazar a um país desautorizado por fora e por dentro" (Portela, 1991, p.40), diz Cardoso Pires em entrevista. Até mesmo o discurso de um secretário do Estado, pronunciado em 1968, no Secretariado Nacional de Informação (SNI), atestava a imutabilidade da organização oficial da censura, como registra Graça Almeida Rodrigues (1980, p.71):

Nada mudou nesta casa; nem o espírito nem a devoção a valores essenciais, nem a linha de acção. Pelo contrário, há, cada vez mais, a forte vontade de cumprir aquilo que um dia, ao criar-se o SNI, foi afirmado por Salazar - de que nós tínhamos que dar aqui testemunho da verdade.

Obviamente, a repressão imposta pela censura do Estado Novo, ou "Estado Social" como queria Marcelo Caetano, fazia-se sentir no enredo das peças de teatro, de forma

10 Em 1968, por motivo de doença, Salazar é obrigado a se afastar do poder e assume o governo Marcelo Caetano, que alterou o nome da PIDE (Polícia Internacional de Defesa do Estado) para DGS (Direcção Geral de Segurança) e da União Nacional para Acção Nacional Popular (ANP). Também rebatizou o regime (Estado Novo) de Estado Social. 
indireta, pela alegoria. Uma característica da dramaturgia desse período é que não foram poucos os dramaturgos que recorreram à história documentada do país em busca de matéria para compor a fábula de suas peças, sendo essa releitura do passado um pretexto para provocar uma reflexão sobre o momento presente. Tratava-se de criar com isso mecanismos de resistência ao regime:

Os autores, não poucas vezes confrontados com um doloroso processo de autocensura, cedo se deram conta que seria necessário tornear as cada vez maiores dificuldades que a censura lhes levantava. Influenciados pelas lições estéticas bebidas no exílio europeu, encontraram na fábula histórica ou - como alguns preferem na parábola histórica - uma forma (disfarçada é certo!) de recuperar as raízes populares historicamente documentadas. Assim, a releitura da nossa história permitia apresentá-la não como passado intocável e institucionalizado, que os ideólogos da ditadura erigiam como epopeia permanente em torno dos grandes mitos nacionais expostos através de conhecida retórica nacionalista. Mergulhar no passado era, antes de mais, fornecer o exemplo (ou exemplos) para, através da reflexão crítica, apelar à acção, tomando consciência de que, apesar da história não se repetir, o passado assume um enorme peso na interpretação do presente. (Barata, 1991, p.356, grifos do autor)

Pensando nos núcleos temáticos de origem histórica das peças produzidas durante o Estado Novo, Barata (idem) faz um levantamento de temas dos quais se apropriaram os dramaturgos desse período. Assim, encontramos o mito do sebastianismo, as revoluções - marcadamente a Revolução Liberal do Porto, em 1820 - e personalidades históricas como temas da dramaturgia portuguesa ao longo de um período de quase quarenta anos. ${ }^{11}$

11 O levantamento dos temas relativos à história de Portugal, feito por 
É preciso aqui esclarecer que essa retomada do passado por meio da história não deve ser confundida com a do tradicional drama histórico do século XIX, ${ }^{12}$ que expressava o ideário romântico da busca ou do fortalecimento da identidade nacional. Diferentemente disso, a matéria histórica, principalmente se unida à estética teatral proposta por Bertolt Brecht - como era o caso de algumas dessas fábulas históricas dos anos 1960 e 1970 -, objetivava levar o espectador a refletir sobre as questões e os problemas da atualidade, posicionando-se criticamente.

Em 1960, José Cardoso Pires publica O render dos heróis - fábula histórica de matriz brechtiana-, abrindo o caminho para que outros dramaturgos seguissem a mesma estética de teatro "que significava afinal uma forma de resistência velada à ditadura então vigente” (Delille, 1991b). A peça sobe ao palco em 1965, pelo Teatro Moderno de Lisboa, ${ }^{13}$ tendo a

Barata (1991), apresenta peças publicadas desde a década de 1940 especificamente, em 1949, a peça El Rei Sebastião, de José Régio-e vai até 1982 com peças de Hélder Costa, JoséSaramago, Luzia Maria Martins, Sinde Felipe e Romeu Correia.

12 Segundo Rebello (1972, p.86-7), a partir de 1886 "as peças de tema histórico multiplicam-se. Não obstante haver nelas um rigor maior na pintura dos costumes evocados e, sobretudo, na sua representação cênica, $[. .$.$] bem como um evidente esforço de adesão aos princípios$ naturalistas, a verdade é que o modelo de quase todas continuava a ser o que, mais de meio século antes, Vitor Hugo havia traçado e Sardou repusera em uso".

13 O Teatro Moderno de Lisboa (1961-1965) foi uma importante companhia dirigida por Rogério Paulo, Costa Ferreira e Fernando Gusmão. Nas palavras de Mário Vilaça (1963, p.212), o TML, ao iniciar suas atividades com a encenação da peça $\mathrm{O}$ tinteiro, de Carlos Muniz, "veio arejar a bafienta e rotineira situação do teatro profissional de Lisboa, procurando fazer um teatro mais vivo, mais actual e actuante, mais renovador”. Graça dos Santos (2004, p.307) considera a encenação, em 1965, de O render dos heróis um marco não só para o teatro português, mas também uma coroação do TML: "Tanto pelo texto [O render dos heróis] e suas ressonâncias brechtianas como pela encenação de Fernando Gusmão, esta criação não só surge 
direção de Fernando Gusmão. Devido à reação positiva do público, a encenação chama a atenção dos censores, ${ }^{14}$ que se dão conta do "equívoco" em tê-la autorizado. Depois de algumas apresentações, o espetáculo fica "limitado à cidade de Lisboa, com proibição, em simultâneo, de qualquer publicidade a anunciá-lo" (Santos, 2004, p.275). Porém, nos dias em que esteve no palco, a divulgação boca a boca manteve o teatro lotado.

Felizmente há luar! foi proibida de ser encenada em Portugal pela Comissão de Censura da ditadura de Salazar. À época de sua publicação em livro, a crítica foi unânime em conferir à obra de Sttau Monteiro indiscutível qualidade estética e os críticos, talvez acreditando na força de seus elogios, pediam a encenação da peça:

Agora podemos dizer que, efectivamente, teatro temos, pelo menos um teatro em potência, uma dessas fontes dramáticas que, graças à sua enraizada trama humana na própria intra-história da inteligência portuguesa, nada poderá estancar, nem sequer a hipótese absurda de não termos actores para representar tão admirável tragédia e a não menos absurda hipótese de esta obra-prima nunca chegar a ser representada. (Simões, 2004, p.142-3)

É isso que quero registar, porque é meu dever que o faça e porque é verdadeiro e porque estes dois actos [de Felizmente

como momento culminante da companhia, comoé paradigmática da evolução que se opera no teatro português entre a década de 1960 e a década de 1970". O TML, por falta de recursos - não tinha apoio financeiro privado nem estatal -, foi obrigado a encerrar suas atividades em 1965 e $O$ render dos heróis foi o seu último espetáculo.

14 Rebello(1977, p.38) explica que, quando a eficácia de uma encenação se mostrava consideravelmente diminuída junto ao público, a peça deixava de ter sobre si o olhar vigilante da censura. Assim, o contrário também é verdadeiro; a eficácia junto ao público chamava a atenção dos censores. 
há luar!] gritam por uma encenação que ponha à prova as qualidades irrefutáveis desta peça a todos os títulos extraordinários de Sttau Monteiro. Ao ser levada à cena, a prova do palco só virá a justificar as minhas afirmações e comprovará as enormes possibilidades e a invulgar potencialidade dramática de uma peça que já nos empolga à simples leitura. (Vilaça, 1962, p.137)

Vilaça (1963b, p.220) volta a elogiar a peça de Sttau Monteiro, um ano depois, fazendo o mesmo apelo: "esta peça merece ser aqui referida e clama por uma encenação imediata e inteligente se os ventos censórios estiverem de feição”. Felizmente há luar! foi levada à cena - mas fora dos palcos portugueses - pelo Teatro Oficina Português de Paris, em 1969, com direção de Carlos César, ${ }^{15}$ e finalmente pôde ser encenada em Portugal ${ }^{16}$ em 1978, com direção do próprio Sttau Monteiro, no Teatro D. Maria II.

Depois da Revolução dos Cravos, Felizmente há luar! e $O$ render dos heróis perderam alguns dos atributos tão positivos mencionados à época pelos críticos; porém, as duas peças conservam ainda hoje a força poética e a qualidade dramática.

No contexto político repressivo em que surgiram essas obras de teatro, os autores experimentavam novas formas dramatúrgicas que pudessem expressar e despertar uma

15 Carlos César, como muitos artistas e intelectuais portugueses, por motivos políticos ficou exilado até 1974 na França, onde deu continuidade à sua atividade teatral, criando o Teatro Oficina Português de Paris, cujo trabalho manifestava a clara oposição ao regime salazarista.

16 Felizmente há luar! teve encenações recentes nos palcos de Portugal: de 2001 a 2008, com montagem do TEP (Teatro Experimental do Porto), direção de Norberto Barroca; de 2006 a 2009, com encenação do grupo teatral A barraca, na direção de Helder Costa, tendo esta montagem participado da "III Mostra Latino-Americana de Teatro de Grupo”, realizada no Centro Cultural de São Paulo, em maio de 2008. 
visão crítica do momento presente. Assim, em Portugal, a dramaturgia produzida nesse período - narrativa e anti-ilusionista - foi a que mais expressou a necessidade de analisar criticamente a realidade e, justamente por isso, a que mais se prestou à resistência ao regime político vigente, tendo sofrido, pois, a mais vigorosa censura.

\section{A obra brechtiana em Portugal}

Na primeira metade do século XX, a cada peça escrita a dramaturgia portuguesa se afastava cada vez mais da linha naturalista de teatro. Fosse pelo "experimentalismo, tributário em grande parte da técnica pirandelliana de desmontagem dos mecanismos em que se assenta a convenção teatral" (Rebello, 1984, p.25), fosse pelo teatro do absurdo ou pela teoria épica brechtiana, os dramaturgos faziam suas escolhas estéticas. Entre essas linhas, tracemos brevemente o percurso do teatroépico brechtiano em Portugal, pois é nesse registro que as peças que nos interessam se inserem.

Segundo Maria Manuela Gouveia Delille(1991a), algumas poucas informações sobre a obra de Bertolt Brecht em Portugal começam a aparecer na década de $1940,{ }^{17}$ em um jornal da imprensa neorrealista, preocupado com o papel social da arte, e no semanário O Diabo (1934-1940), de crítica literária e artística, ligado a setores oposicionistas, que publica a tradução de um trecho do texto de Brecht "Cinco dificuldades ao escrever a verdade", integrando um conjunto de artigos que tinham como tema a função do escritor no mundo. De 1945 a 1949 - ainda conforme o levantamento de Delille(idem) - não há registros sobre o conhecimento da

17 De acordo com a mesma autora, antes da década de 1940 somente há "umas brevíssimas alusões [a Brecht] feitas por Julio Dantas, em 1925” (Delille, 1991a, p.63). 
obra de Brecht pelos artistas portugueses e, provavelmente, isso se deve à escassez de edições das obras brechtianas, à dificuldade com a língua alemã e à inexistência, até meados dos anos de 1950, de traduções de Brecht para o inglês e para as línguas latinas. As primeiras referências, de fato, à obra de Brecht datam de 1949, são de autoria de Luiz Francisco Rebello - grande crítico, historiador do teatro português e dramaturgo, que contava na época com apenas 25 anos de idade - e foram publicadas principalmente no periódico Vértice - Revista de Arte e Cultura, que evidenciava "forte empenhamento político-social de raiz marxista" (idem, p.64), fazendo, pois, oposição à ditadura salazarista.

Na segunda metade da década de 1950, os portugueses começaram a ter acesso à obra de Brecht primeiramente pela tradução francesa, e os poucos artigos então publicados em Portugal-apesar dos esforços dos apreciadores de Brecht em explicar e divulgar a teoria do teatro épico e a obra dramática do dramaturgo alemão - apresentavam certas reduções ou equívocos sobre a estética brechtiana como, por exemplo, a afirmação de que Brecht pregava a falta de emoção do ator e, por conseguinte, também do espectador.

Em 1955, José Redondo Júnior (1955, p.241) afirma estar "apaixonadamente interessado no estudo de Geneviève Serreau sobre o grande dramaturgo, encenador e teatrólogo alemão Bertolt Brecht, [...] que apresentou Mère Courage, a mais espantosa revelação". Entusiasmado com a obra brechtiana, o teatrólogo e jornalista português tece, nesse mesmo artigo, algumas considerações sobre o teatro épico. No final da década de 1950, de acordo com Delille (idem), é Luiz Francisco Rebello o grande divulgador das ideias e da obra de Brecht. Rebello publica, em 1957, em seu Teatro Moderno, a tradução para o português da peça $A$ exceção e a regra. Em 1961, Redondo Júnior publica o livro Panorama do Teatro Moderno, em que trata de estéticas teatrais, explica o famoso efeito- $V$ brechtiano e apresenta a tradução - feita 
a partir da versão francesa - de fragmentos das peças Mãe Coragem e seus filhos e $O$ círculo de giz caucasiano. Além de Luiz Francisco Rebello e Redondo Júnior, Mário Vilaça também foi um importante propagador da obra de Brecht em Portugal nos anos de 1960 e publica ensaios na revista Vértice sobre o teatro brechtiano.

O interesse pela obra dramática e pelas teorias brechtianas de teatro aumenta consideravelmente entre 1958 e 1968 , despertando cada vez mais o desejo dos artistas portugueses em levar aos palcos as peças do dramaturgo alemão. Assim, houve, por exemplo, uma tentativa da Cia. Rey ColaçoRobles Monteiro de encenar Mãe Coragem e seus filhos, de Brecht, mas foi sempre impedida pelo Conselho de Leitura, ou seja, censura prévia ao texto. ${ }^{18}$

Nesse tempo, o regime salazarista passava por um momento de crise, abalado pelas eleições presidenciais de $1958^{19}$ e pela formação de guerrilhas nas colônias africanas, na década de 1960, em luta pela independência. Diante da crise, a ditadura intensificou ainda mais os mecanismos de repressão no país. Como o teatro era sempre o maior alvo da Comissão de Censura salazarista, a obra dramática de Brecht continuou banida dos palcos portugueses, salvo raríssimas exceções.

Como aponta Rebello (1977), poucas encenações da obra de Brecht realizadas por companhias estrangeiras ou por grupos universitários foram autorizadas, mas nem

18 A correspondência trocada pela atriz Amélia Rey Colaço com os representantes alemães da obra de Brecht é mencionada por Graça dos Santos (2004) e registrada por Maria Manuela Gouveia Delille (1991b).

19 A candidatura de Humberto Delgado à presidência, concorrendo com o candidato do regime, Américo Tomás - que ganha as eleições-, foi um grande movimento de oposição a Salazar. É famosa a frase de Delgado em uma entrevista em que, quando perguntado sobre o que faria em relação a Salazar se ganhasse as eleições, ele imediatamente responde: "Demito-o". 
sempre lhes era permitido permanecer em cena e cumprir a prevista temporada de espetáculos. É famoso o caso da peça A alma boa de Setsuan, levada à cena em Portugal, no ano de 1960, pela Companhia do Teatro Popular de Arte do Brasil - também conhecida como Companhia de Maria Della Costa, atriz que fez o duplo papel de Chen Te e Chui Ta. Após cinco apresentações tumultuadas por protestos de intelectuais de extrema-direita e pela reprovação do espetáculo pela imprensa situacionista lisbonense, a encenação foi proibida pela censura. Na imprensa da época, ${ }^{20}$ registraramse demonstrações de repúdio ao "escritor comunista", referência a Brecht, e à peça, cujos três deuses, personagens que nela aparecem, foram interpretados como uma "alusão desrespeitosa à Santíssima Trindade”. Todas as peças de Brecht continuaram proibidas de subir à cena.

Mesmo na chamada "Primavera Marcelista" - que Cardoso Pires ironizou como "Inverno Marcelista" - não houve nenhuma mudança no que se refere à proibição das obras de Brecht nos palcos lusos. O público português foi privado de conhecer encenações das peças de Brecht até 25 de abril de 1974 .

$\mathrm{Na}$ tentativa de burlar a censura, fragmentos de obras teatrais ou poemas de Brecht eram introduzidos, sem a citação do nome do autor, em espetáculos teatrais autorizados. Não foram poucas as tentativas de levar à cena as obras brechtianas, e uma ou outra encenação de grupos universitários era possível, desde que apresentada somente a alunos. Durante a década de 1960, ficaram por conta do teatro amador ou universitário as encenações "fechadas"

20 A maior referência até o momento sobre a recepção de Brecht em Portugal é o valiosíssimo trabalho orientado e organizado por Maria Manuela Gouveia Delille (1991b). No livro, as autoras apresentam cópias dos artigos publicados na imprensa da época, referentes à encenação de A alma boa de Setsuan pela companhia de Maria Della Costa. 
ou as representações clandestinas ou semiclandestinas de trechos da obra dramática de Brecht, que obviamente alcançavam apenas um pequeno público:

É o caso de A excepção e a regra em 1960, pelo Círculo de Iniciação Teatral da Academia de Coimbra (encenação de Ricard Salvat), e de cenas extraídas de diferentes peças, apresentadas pelo Grupo Cênico da Associação de Estudantes do Instituto Superior Técnico (IST), durante o ano escolar de 1968-1969, sob a direcção de Mário Sério. É o reduzido alcance desses espetáculos, com um público muito restrito, que permitia o seu [de Brecht] esporádico aparecimento. (Santos, 2004, p.277)

A Comissão de Censura foi, entretanto, menos rígida em relação à publicação em livro da obra dramática de Brecht. Inicialmente as peças foram sendo traduzidas parcial ou integralmente e publicadas em artigos de periódicos ou em livros sobre estética teatral. No início da década de 1960, a Portugália Editora começa um projeto de divulgação da obra dramática do autor de Mãe Coragem e seus filhos, sendo essa peça e A alma boa de Setsuan integrantes do primeiro volume da série Teatro I, com tradução para o português de Ilse Losa, ${ }^{21}$ escritora alemã radicada em Portugal.

A teoria do teatro épico era de grande interesse entre os autores portugueses, que viam nos pressupostos de Brecht

21 A tradução de Ilse Losa é bastante criticada por Mário Vilaça. A tradutora publica carta em resposta às críticas do ensaísta e ele lhe responde. Mesmo sem conhecer a tradução de Losa, fica difícil não dar razão a Mario Vilaça (1963a, p.89), pois ao lermos a carta da tradutora em defesa própria encontramos muitos erros de português, fato que o ensaísta não deixa de criticar: "tenho de dizer-lhe [a Ilse Losa] que, como tradutora, tem mostrado sempre, em tudo o que escreve, que não sabe português. Por isso mesmo se chamou a atenção para os erros excessivos de português que uma simples carta sua, de quatro páginas dactilografadas, nos exibe. Eles bastam só por si para me dar razão". 
a possibilidade de uma inovação no teatro de então e, por isso, procuravam compreender e explicar em seus artigos as técnicas brechtianas. Tornava-se claro que o teatro épico se realiza, de fato e efetivamente, na encenação, sendo a dramaturgia, o texto, apenas parte do fenômeno teatral. Por isso, os divulgadores das ideias de Brecht clamavam por encenações das peças do dramaturgo. Em realidade, as peças de Brecht - como grande parte da dramaturgia portuguesa produzida nessa época - eram conhecidas por meio do livro e não do palco. O teatro de Brecht em Portugal era lido e não encenado.

Segundo José Redondo Júnior (1961, p.45), a "reinvenção do teatro" - e para ele o efeito-V de Brecht é "um dos fatores essenciais da mais moderna reinvenção do teatro" - se dá principalmente pela ação do encenador, mais que pelo trabalho do dramaturgo, e destaca a montagem épica da peça de Friedrich Dürrenmatt, com encenação de Cayetano Luca de Tena, na temporada de 1959/60 no teatro D. Maria II, fazendo, em seu comentário, uma clara referência ao famoso esquema de Brecht que opõe a forma épica à forma dramática de teatro:

É que, em A Visita [da Velha Senhora, de Dürrenmatt], está bem expressa a fórmula brechtiana: a cena conta a acção; torna o público espectador dessa acção; desperta a actividade do espectador; o espectador opõe-se à acção; o teatro funciona por argumentos; o homem muda; o ser social condiciona o pensamento. (idem, p.44, grifo do autor)

Mas diante da situação em que se encontrava o teatro português - silenciado nas páginas dos livros, quando muito, ou encerrado nas gavetas dos dramaturgos - a representação épica estava um tanto distante da realidade. Antes das traduções portuguesas da obra de Brecht, notícias sobre o teatro épico acabavam chegando ao país 
e os meios de se obter conhecimento da obra brechtiana e assimilá-la eram os mais variados:

Quer através da leitura de traduções brechtianas francesas e/ou inglesas e de estudos sobre a nova dramaturgia, quer através de estadas mais ou menos longas na França, Inglaterra ou Alemanha, onde assistem à representação de peças de Brecht por companhias europeias célebres, alguns dos nossos mais conhecidos escritores, encenadores e actores adquirem conhecimentos seguros sobre a teoria e a prática do teatro épico, que logo procuram transpor para a criação literária ou para a praxis teatral próprias. (Delille, 1991a, p.73)

Obviamente, as ideias teatrais de Brecht não foram acolhidas por todos. Críticas e questionamentos aos pressupostos brechtianos de teatro apareciam aqui e ali. João Gaspar Simões, por exemplo, deixava claro em seus artigos um certo desdém pelas técnicas brechtianas, principalmente se empregadas na dramaturgia portuguesa, embora reconhecesse o mérito de peças como $O$ render dos heróis e Felizmente há luar!. Mesmo os escritores e dramaturgos expressavam certa cautela em comentários sobre o teatro épico. O fato de esse teatro ser definido como antiaristotélico e de ter o ator como principal responsável pelo alcance do efeito de distanciamento são os questionamentos mais comuns. $\mathrm{O}$ que ocorre, na verdade, é que no final da década de 1960 a importância do teatro de Brecht começa a ser relativizada pelos intelectuais e artistas portugueses, apesar de ressurgir o interesse pela obra do dramaturgo alemão logo depois da Revolução de 25 de abril e suas peças passarem a ser das mais encenadas em Portugal na década de 1970.

No âmbito da recepção reprodutiva dos pressupostos brechtianos no período que nos interessa, a frequência de dramas portugueses de caráter histórico narrativo "é claro testemunho, por parte dos escritores nacionais, de leituras brechtianas ou de contacto directo com a obra do drama- 
turgo alemão em palcos estrangeiros, sobretudo franceses e ingleses" (idem, p.81). Tal produção dramatúrgica filia-se a Brecht para reafirmar o seu caráter de resistência às formas repressivas do Poder instituído, em uma tentativa de libertação da expressão artística e do pensamento crítico. 


\section{2 \\ Algumas CONSIDERAÇões SOBRE O TEATRO ÉPICO DE BRECHT}

Necessitamos de um teatro que não nos proporcione somente as sensações, as ideias e os impulsos que são permitidos pelo respectivo contexto histórico das relações humanas

(o contexto em que as ações se realizam), mas, sim, que empregue e suscite pensamentos e sentimentos que desempenhem um papel na modificação desse contexto. (Brecht, 2005, p.142)

Muito já se escreveu sobre Bertolt Brecht (1898-1956), sua obra teórica, sua literatura dramática, seu teatro vivo, seu pensamento, suas ideias, suas contradições, sua posição política, antes e depois de sua morte, ontem e ainda hoje. Assim, encontramos comumente o Brecht dramaturgo, o Brecht poeta, o Brecht político, o Brecht polêmico, os "pecados de Brecht" (Arendt, 1999)... Ou, ainda, em uma visão mais abrangente e de dimensão filosófica, o conjunto que une a linguagem, o pensamento e a prática narrativa de 
Brecht. ${ }^{1}$ Sobre a personalidade e a vida do autor alemão há também um grande número de referências espalhadas pelo mundo. As palavras de Hannah Arendt (idem, p.194-5) sobre Brecht definem a personalidade, no mínimo curiosa, do dramaturgo:

Este, então, era o homem: dotado de uma inteligência penetrante, não teórica, não contemplativa, que ia ao centro do assunto, silencioso e relutante em se revelar, distante e provavelmente também tímido, de qualquer forma não interessado em si mesmo, mas incrivelmente curioso (de fato "o Brecht sedento de conhecimento", como se referiu a si mesmo na "Canção de Salomão", em A ópera dos três vinténs) e, primeiro e acima de tudo, poeta - isto é, alguém que tem de dizer o indizível, que não consegue ficar quieto nas ocasiões em que todos estão quietos, e portanto deve ter cuidado em não falar demais sobre coisas de que todos falam.

No que se refere especificamente ao teatro, Brecht dividiu opiniões, fez com que toda espécie de críticos se voltasse a favor ou contra suas ideias teatrais "pessoais ou tomadas de empréstimo” (Szondi, 2001), visse em suas cenas, para o bem e para o mal, um certo didatismo, uma pedagogia a ser seguida ou ainda algo de formalismo em sua concepção e técnicas de distanciamento; assim, "naturalmente as ideias de Brecht colocam problemas e suscitam resistências" (Barthes, 1999, p.131). Há, porém, uma unanimidade entre tantos que opinaram sobre o "escrevinhador de peças"2 que está no

1 Jameson (1999, p.53) propõe o que ele denomina "triangulação com Brecht”, ou seja, que nenhuma das áreas ou dimensões do trabalho de Brecht - linguagem, modo de pensar, narrativa - tem qualquer prioridade sobre as outras, mas que "elas podem ser vistas como tantas outras projeções umas das outras em diferentes meios, assim como um fenômeno cristalino poderia assumir diferentes aparências no domínio de ondas de luz enquanto permanece o 'mesmo"'.

2 SegundoWilma Rodrigues (1970-1971), Brecht evitava escrever em 
reconhecimento da dramaturgia brechtiana como obra de grande força criativa e inovadora do teatro moderno, apesar de a discussão a respeito de Brecht ter também se voltado mais tarde para a questão da atualidade ou não de seu teatro épico. Não cabe aqui fazer tal julgamento, embora consideremos as posições de Roberto Schwarz (1999) e Sérgio de Carvalho (2009) 3 especialmente enriquecedoras para a compreensão do porquê dessa discussão, ainda que eles se refiram mais especificamente ao contexto brasileiro.

O Brecht que nos interessa neste momento éo "encaminhador de propostas", como ele mesmo se definiu (Jameson, 1999), o que não significa necessariamente excluir por completo de nossas considerações sua poesia, por exemplo. Sobre os escritos sistemáticos de Brecht, Barthes (1999, p.136) atenta que "não é de modo algum enfraquecer o valor criativo desse teatro [épico brechtiano] considerá-lo como um teatro pensado". Assim, interessa-nos o trabalho teórico sobre o teatro épico proposto pelo dramaturgo alemão.

A teoria teatral desenvolvida por Brecht aparece um tanto dispersa ${ }^{4}$ em sua obra de reflexão e registro

primeira pessoa em seus textos teóricos sobre teatro e empregava preferencialmente o termo Stückeschreiber - escritor de peças de teatro - no lugar de "dramaturgo". Nos trabalhos de Ingrid D. Koudela sobre o dramaturgo aparece a expressão "escrevinhador de peças" como tradução do termo alemão.

3 Sérgio de Carvalho - na posição de encenador de obras de Brecht e representante do grupo paulistano de teatro Cia. do Latão-descreve o episódio em que Roberto Schwarz explica "as razões pelas quais Brecht perdeu a atualidade" e procura refutar os posicionamentos do crítico.

4 Apesar de Brecht dedicar um ensaio às formas de representação épica - "A nova técnica da arte de representar" -, muitas das técnicas indicadas por ele são descritas em outros textos; por exemplo, encontramos descrições mais precisas sobre o trabalho do ator em "Pequeno órganon para o teatro" (Brecht, 2005, p.125-66), ensaio que contém um prólogo e 77 breves parágrafos sobre os termos que emprega para expressar sua ideia de teatro. 
teóricos, devido à sua proposta de experimentação e de trabalho sempre em processo que caracterizou a práxis de seu teatro. Estudiosos de Brecht, no entanto, agruparam as técnicas teatrais recomendadas por ele de acordo com as várias partes do todo que compõem a cena dita épica. Sendo assim, é de consenso que o alcance do efeito de distanciamento - elemento caracterizador do teatro épico - envolve principalmente o trabalho do ator, uma certa caracterização do espaço cênico e a forma de utilização da música no palco. Faz-se necessário citarmos aqui, como exemplo, a descrição sucinta da obra de dois autores que organizaram os pressupostos teóricos brechtianos de teatro, tornando-se uma referência para os leitores de língua portuguesa, e comentarmos rapidamente um ensaio e uma tradução de autores portugueses sobre o teatro de Brecht. Essas obras de autores brasileiros e portugueses nortearam a fundamentação teórica do nosso estudo.

O teatro épico, de Anatol Rosenfeld (2006), cuja primeira ediçãoé de 1965, apresenta um percurso histórico do gênero épico a partir da teoria dos gêneros e mostra que os traços narrativos no teatro aparecem já na tragédia grega. Além disso, o livro reúne, no que diz respeito especificamente à teoria de Brecht, as técnicas de distanciamento em um conjunto de recursos classificados como: literários; cênicos e cênicos-literários; cênicos-musicais e, por último, o ator como narrador. Os recursos literários tratam principalmente da comicidade, já que "Um dos recursos mais importantes de Brecht, no âmbito literário, é, pois, o cômico, muitas vezes levado ao paradoxal" (idem, p.157), e se inserem aí a paródia e a ironia como processos que desempenham a função cômica, visto que para se produzir o riso é necessário distanciar-se da situação que o provocou. Nos recursos cênicos e cênicos-literários está a utilização de cartazes, títulos, projeções de textos que comentam de forma narrativa as ações, "teatralizando" a literatura e também tornando a 
cena literária. Os recursos cênicos-musicais utilizam coros e cantores que se dirigem diretamente ao público. $\mathrm{O}$ ator da representação épica, para trabalhar o efeito de distanciamento, dirige-se não só aos que estão no palco, mas também diretamente ao público. Clareando a ideia de representação cênica de Brecht, Rosenfeld (idem, p.161) explica que o ator “deve 'narrar' o seu papel, com o 'gestus' de quem mostra um personagem, mantendo certa distância dele".

O filósofo brasileiro Gerd Bornheim(1992), em seus estudos sobre a estética teatral de Brecht, parte das tendências do naturalismo e expressionismo no teatro e chega aos trabalhos de Brecht, que examina da juventude até a maturidade do autor alemão. Bornheim explica, na nota introdutória, que o tema do seu livro está "na evolução e no ordenamento das ideias estéticas do dramaturgo". Na terceira parte do ensaio, a que aqui mais nos interessa, Bornheim explica o efeito de distanciamento a partir do público - para quemé estabelecida a finalidade do distanciamento; a partir do ator-principal responsável pelo alcance do efeito no palco; a partir das cenas, dos elementos cênicos e da música, mostrando o tratamento estético que Brecht deu aos seus songse, finalizando, Bornheim faz algumas considerações a respeito do distanciamento a partir do diretor - ainda que, como ele mesmo afirma, Brecht não tenha deixado registros a esse respeito - e comenta, no final, peças e ensaios do dramaturgo.

No contexto do teatro português, a tradução que em 1964 Fiama Pais Brandão fez da coletânea dos textos teóricos de Brecht, organizada por Sigfried Unseld, tornou-se uma obra de referência (em Portugal e no Brasil), assim como os ensaios que divulgaram o teatro épico brechtiano em Portugal, de autoria de Luiz Francisco Rebello, Redondo Júnior e Mário Vilaça. Embora os textos desses autores tenham sido escritos, em sua maioria, depois de terem sido publicadas as peças que aqui analisamos, são fundamentais para se ter uma noção da compreensão da teoria brechtiana naquele país. $\mathrm{O}$ 
importante ensaio de Mário Vilaça, Do teatro épico (1966), por exemplo, preocupa-se em elencar e esclarecer algumas das "noções erradas que muito vulgarmente se ouvem por aî" a respeito da teoria brechtiana. Citando Anatol Rosenfeld, o ensaísta português esclarece que o teatro épico "não pretende eliminar ou destruir a emoção", que o teatro épico "opõe-se à catarse, mas à catarse como único objectivo do drama", que, apesar de o teatro épico se opor ao naturalismo e ao palco à italiana, "não se conclua daí, como é frequente, que sãoépicas todas as peças não naturalistas". MárioVilaça explica também que a diversão faz parte do teatro épico e que a peça épica não pode ser confundida com a chamada "peça de tese" ou "peça de propaganda" e, por último, queo teatro épico não se deixa "limitar ao campo do psicologismo e da interpretação psicológica”. Parece-nos, ainda, que um ponto conclusivo de MárioVilaça (idem, p.273) nos dá uma medida do que para ele interessa no teatro épico: "O desafio lançado pelo teatro épico é, em última análise, a criação de um teatro responsável socialmente enquanto conteúdo e ousado artisticamente enquanto forma”.

Nãoé nossa pretensão continuar a fazer aqui uma síntese de cada historiador de teatro, teórico, estudioso, ensaísta que se debruçou sobre a obra teórica de Brecht, porque isso seria praticamente impossível. A nossa intençãoé apresentar algumas considerações sobre as propostas teóricas de Brecht acerca do seu teatro épico com o objetivo de preparar um pouco o caminho que a seguir se abrirá para a análise das duas peças consideradas os primeiros frutos da perspectiva brechtiana de teatro em Portugal.

\section{O olhar épico da distância}

Ao longo de quase trinta anos, Bertolt Brecht escreveu uma variedade de textos a respeito da sua teoria teatral, 
que foi, até sua morte, em 1956, complementada, alterada, revista. Ao lermos os ensaios brechtianos, precisamos considerar o fato de que sua obra teórica apresenta os resultados e as reflexões de sua práxis teatral, refletindo, pois, as atividades desempenhadas por Brecht como dramaturgo, teórico e encenador - junção efetiva, portanto, da teoria e da prática. Nesses textos, encontram-se, em uma abordagem complexa, os famosos termos empregados pelo dramaturgo alemão na composição de sua teoria: teatro épico, efeito de distanciamento (Verfremdungseffekt), ${ }^{5}$ gestus social, conceitos de difícil definição. Os ensaios teóricos de Brecht contêm também descrições de encenações de peças de sua autoria, que ele próprio dirigiu, ou de outros exemplos de peças que ele, como atento espectador, assistiu; apresentam críticas ao teatro naturalista, ao qual o seu teatro épico se opõe, e contestação dos pressupostos aristotélicos de dramaturgia, como é sabido.

O registro da teoria brechtiana, principalmente por grande parte ser fruto das experiências de Brecht no palco, não escapou de ser transformado em uma verdadeira fórmula de encenação por realizadores do espetáculo teatral. Para Fernando Matos Oliveira (1997), o próprio Brecht acabou contribuindo para que seus apontamentos fossem

5 O termo "Verfremdungseffekt", com que Bertolt Brecht designa o princípio básico de sua dramaturgia, já foi traduzido para o português como "distanciamento", "efeito de distanciação", "estranhamento", "efeito-V” e até "alienação" (termo advindo de algumas traduções francesas). Em Portugal, Renato Correia (1985), ao defender o termo estranhamento como o melhor para a tradução para o português, criou um debate em torno do assunto, sendo contestado por António Sousa Ribeiro (1985). Maria Manuela Gouveia Delille (1991a / 1991b) utiliza o termo "estranhamento". MarioVilaça(1966) prefere a tradução "efeito de estranhamento ou efeito de alheamento". Anatol Rosenfeld (2006) escreve "efeito de distanciamento (Verfremdungseffekt = efeito de estranheza, alienação)”. Gerd Bornheim (1992) também utiliza o termo "distanciamento". No presente trabalho, utilizamos distanciamento, efeito- $\mathrm{V}$ ou o termo em alemão. 
vistos como receituários quando elaborou o famoso quadro em que contrapõe as características do teatro dramático às do teatro épico. É preciso lembrar, no entanto, que o tratamento que o dramaturgo alemão dá à forma de seu teatro constitui um método ou sistema próprio. Brecht sabia da dificuldade que é descrever o estilo de representação épica e das tentativas de encenação que se fizeram fora de seu domínio, muitas vezes levadas a banalizações e equívocos, ${ }^{6}$ como a "aparência de que se pretende eliminar tudo o que seja emocional, individual, dramático etc." (Brecht, 2005, p.222). Por outro lado, Brecht foi o primeiro a reconhecer que seu teatro épico não apresentava nenhuma novidade ${ }^{7}$ e reiterou inúmeras vezes que seu projeto teatral era um experimento, que o processo estava em andamento, que as experiências constantes de encenação o faziam rever e reformular suas ideias, muitas das vezes complementadas pelos companheiros de teatro, atuantes e colaboradores, como a atriz Helene Weigel, o cenógrafo Caspar Neher, o músico Kurt Weill e outros compositores.

O teatro épico também foi designado por Brecht como "teatro não aristotélico" devido às suas oposições a certos pressupostos que o filósofo grego faz em sua Poética. O ponto principal dessa oposição, como se sabe, refere-se à questão da identificação com o herói por parte do espectador:

A identificação é uma das vigas-mestras sobre as quais repousa a estética dominante. Na sua admirável Poética,

6 No texto "De uma carta a um ator", Brecht lamenta a interpretação equivocada, segundo ele, de seus escritos sobre a arte de representar e atribui isso à sua forma de redação: "Tal impressão provém, decerto, da minha maneira de escrever, que toma demasiadas coisas por evidentes. Maldita maneira!" (Brecht, 2005, p.253).

7 Vilaça(1966, p.264) aponta nas peças históricas de Shakespeare "poderosos traços épicos" por evocar o ambiente social das personagens, "enquadradas na evolução dialéctica dos acontecimentos". 
Aristóteles já descreve como, por meio da mimesis, é produzida a catarsis, isto é, a purificação da alma do espectador. $\mathrm{O}$ ator imita o herói (Édipo ou Prometeu) com uma tamanha força de sugestão e uma tal capacidade de metamorfose, que o espectador imita o imitador e toma para si o que vive o herói. [...] O que gostaria de dizer-lhes, agora, é que toda uma série de tentativas no sentido de fabricar, com os meios do teatro, uma imagem manejável do mundo, conduziram a suscitar a questão perturbadora de saber se, por isso, não seria necessário abandonar de alguma forma a identificação. É que, se não se considera a humanidade (suas relações, seus processos, seus comportamentos e suas instituições) como alguma coisa de dado e imutável, e se se adota em relação a ela a atitude que se teve, com tanto sucesso desde alguns séculos, em relação à natureza, essa atitude crítica que procura transformar a natureza, com o objetivo de a dominar, então não se pode recorrer à identificação. Impossível identificar-se com seres transformáveis, participar de dores supérfluas, abandonar-se a ações evitáveis. (idem, 1967, p.135, grifo do autor)

A partir dessa perspectiva, Brecht irá se perguntar o que aconteceria ao espectador se lhe fosse proibida "a atitude passiva, embebida de sonho, do homem lançado ao seu destino" e sugere que o espectador deveria ser introduzido, bem desperto, em seu mundo real, já que toda a dramaturgia brechtiana postula que "a arte dramática deve menos exprimir o real do que significá-lo” (Barthes, 1999, p.133). Nessa linha de pensamento, Brecht desenvolve a proposta primordial do teatro épico, queé a de narrar os acontecimentos relacionados à realidade, com o objetivo de despertar o senso crítico no espectador diante das cenas apresentadas. Para explicar o efeito da "técnica de identificação" e o da "técnica de distanciamento", Brecht toma como exemplo a cólera de Lear - Rei Lear, de Shakespeare -, devida à ingratidão de suas filhas. Segundo Brecht, usando a técnica de identificação o ator representa a cólera de Lear de modo 
que o espectador irá considerá-la a coisa mais natural do mundo. Por outro lado, usando a técnica de distanciamento, o ator representa a mesma cólera de Lear de forma tal que restará ao espectador "a possibilidade de se espantar com ela, de imaginar, para Lear, outras reações possíveis além da cólera" (Brecht, 1967, p.137).

Objetivar a reflexão e a crítica não quer dizer, no entanto, negar completamente a emoção, como se poderia pensar. $\mathrm{O}$ fato de Brecht contestar especificamente a teoria da catarse não significa que ele irá suprimir totalmente a possibilidade de emoção da sua teoria de teatro. O que ocorre no teatro épico brechtiano é a rejeição daquela emoção que visa à identificação do público com a cena, com a personagem, e leva o espectador ao plano da ilusão. O que Brecht sugere, na verdade, é um deslocamento das emoções - por meio de um tipo de atuação do ator e da utilização de determinados recursos - que provoca outras e novas formas de emoção, elevando o espectador ao plano da reflexão, da análise, da crítica. E isso só pode se dar por meio do Verfremdungseffekt, que ele propõe no lugar da identificação, da catarse aristotélica, como proposta de "tornar efetivamente possível um prazer artístico fundado no princípio do distanciamento" (idem, p.140).

Muitos estudiosos das letras e do teatro viram na obra Mãe Coragem e seus filhos, de Brecht, uma grande possibilidade de o espectador se emocionar com essa mãe, que no meio da guerra vai perdendo cada um de seus filhos. O efeito de distanciamento é capaz de transformar essa emoção que leva à entrega total do espectador, fazendo-o abandonar-se a ela - Brecht chama de "empatia por abandono" - em um outro tipo de emoção que leva à análise crítica da situação narrada, e disso vai depender muito o trabalho de atuação do ator. Na explicação de Brecht (2005, p.81), o efeito de distanciamento "não se apresenta sob uma forma despida de emoções, mas, sim, sob a forma de emoções bem deter- 
minadas, que não necessitam encobrir-se com as da personagem representada", o que significa que nãoé pela empatia apenas que a emoção pode ser desencadeada: "Perante a mágoa, o espectador pode sentir alegria; perante a raiva, repugnância”. Brecht propõe, então, o distanciamento no lugar da empatia.

É de consenso entre os teóricos de teatro que o efeito de distanciamento também não é uma invenção de Brecht ${ }^{8}-$ ele próprio apontou o distanciamento em obras teatrais e pictóricas nas feiras anuais da Alemanha, e reconheceu-o nas pinturas surrealistas. Muitas definições de Verfremdungseffekt foram apresentadas por Brecht em seus ensaios. Segundo Jameson (1999, p.63-4), o termo "parece ter migrado do ostranenie ou 'ato de tornar estranho' dos formalistas russos depois de inúmeras visitas a Berlim por soviéticos modernistas como Eisenstein ou Tretiakov". Como se sabe, Brecht analisou o Verfremdungseffekt principalmente na arte dramática chinesa em Efeitos de distanciamento na Arte Chinesa, ensaio que "representa a primeira discussão abrangente que Brecht empreendeu sobre o conceito capital de Verfremdung” (Carlson, 1997, p.372-3). Jacques Desuché (1966, p.67) afirma que "Brecht no se presentó jamás como el inventor de este célebre 'efecto $V$ '. Desarrolló la doctrina, no creó la cosa: el 'efecto $V$ ' se manifiesta ya en ciertas circunstancias de la vida cotidiana".

Estranhar algo que nos é habitualmente familiar, a partir do momento em que somos chamados a prestar detida atenção àquilo que nos é comum, é a manifestação do distanciamento presente na vida cotidiana. Brecht ilustra esse tipo de distanciamento com o famoso exemplo

8 Rosenfeld (2006, p.152) mostra que Schiller exigia o distanciamento para aumentar a grandeza do espetáculo com a introdução do coro: "Enquanto Schiller, em última análise, almeja um estado estéticolúdico, apartado da vida imediata, Brecht se empenha, através da mediação estética, pela ativação política do espectador”. 
de perguntar a um interlocutor se ele já parou para olhar atentamente seu relógio (do interlocutor); ao fazê-lo a pessoa toma a distância necessária para a análise daquele objeto tão familiar. Para os gregos, explica Anatol Rosenfeld (2006, p.155), o distanciamento provocava a surpresa que "se afigurava como o início da investigação científica e do conhecimento", o que não deixa de significar uma espécie de despertar diante do que se apresenta como comum. Por isso que, no palco, tudo se conjuga de forma tal para que o espectador se conscientize de que nada que foi apresentado na cena "é inevitável ou inalterável”, é nisso que "reside a força da produção épica [...], nessa convicção e no ensinamento de que a história e a natureza humana não são imutáveis, havendo sempre a possibilidade de nos transformarmos e de transformarmos o mundo" (Vilaça, 1966, p.274). É nesse sentido que está a dimensão ou formulação política do efeito- $\mathrm{V}$ :

Aqui, o familiar ou habitual é novamente identificado como "natural" e seu estranhamento desvela aquela aparência, que sugere o imutável e o eterno, e mostra que o objeto é "histórico". A isso deve-se acrescentar, como corolário político, que é feito ou construído por seres humanos e, assim sendo, também pode ser mudado por eles ou completamente substituído. (Jameson, 1999, p.65)

Em sua práxis teatral, Brecht (2005, p.146) criou técnicas que tencionam provocar no espectador essas duas reações, a de surpresa e a de estranheza, a fim de produzir o distanciamento:

As oscilações surpreenderam-no [Galileu, quando contemplava o lustre que oscilava], como se jamais tivesse esperado que fossem dessa forma, como se não entendesse nada do que se estava passando; foi assim que descobriu a lei do pêndulo. $\mathrm{O}$ teatro, com as suas reproduções do convívio 
humano, tem de suscitar no público uma visão semelhante, visão que é tão difícil quanto fecunda. Tem de fazer que o público fique assombrado, o que conseguirá, se utilizar uma técnica que o distancie de tudo que é familiar.

O espectador do teatro épico, ao se distanciar, assume uma posição analítica perante os acontecimentos narrados nas cenas. Com efeito, o distanciamento ativa uma reação no espectador, tira-o da passividade, coloca-o no movimento da reflexão. Nesse sentido, podemos dizer que o distanciamento produz o efeito contrário da empatia, a qual, para Brecht, pode levar o espectador à marginalização do espírito crítico, já que se identificar com a cena significa reconhecer-se nela, envolver-se com ela, impossibilitando, pois, um momento de afastamento para o despertar de uma reação crítica. Na explicação de Rosenfeld (2006), estando identificados com as coisas corriqueiras, não as vemos com o "olhar épico da distância" e ficamos abandonados à situação habitual que nos parece eterna; é só por meio do distanciamento que nós mesmos e a nossa situação podemos nos tornar objetos de nosso juízo crítico.

O teatro épico empenha-se em ensinar ao espectador "um determinado comportamento prático com vista à modificação do mundo, deve suscitar nele uma atitude fundamentalmente diferente daquela a que está habituado" (Brecht, 2005, p.47); é notório, pois, o caráter didático ${ }^{9}$ desse tipo de teatro, que, muitas vezes, justamente por essa razão, foi largamente criticado. Não é nosso propósito abrir aqui uma discussão sobre a função da arte dramática, porém a questão do elemento didático como proposta presente - às

9 Brecht (1967, p.127) reconhece que a tentativa mais radical de conferir caráter didático ao teatro foi empreendida por Erwin Piscator: "Participei de todas as suas experiências [de Piscator]; nenhuma delas que não tenha tido por objetivo desenvolver a função didática da cena". 
vezes de forma mais indireta - na obra teórica de Brecht deve ser considerada.

Rosenfeld (2006) aponta duas razões pelas quais o teatro épico se opõe ao aristotélico. A primeira é que não pretende apenas apresentar relações entre os indivíduos, mas as "determinantes sociais dessas relações", e a segunda é que o homem deve ser visto no "conjunto de todas as relações sociais”. A essa segunda razão liga-se o "intuito didático” do teatro de Brecht: "O fim didático exige que seja eliminada a ilusão, o impacto mágico do teatro burguês” (idem, p.148). Para Bentley (1991, p.318), o que surpreende na obra de Brecht é como o dramaturgo transforma suas lições em obra de arte: "Pode deixar de ser arte se a alegoria for direta e ponderada ou se a propaganda for ansiosa e importuna. Brecht consegue escapar dessas armadilhas, e o resultado é alguma coisa inteiramente nova no teatro didático”. A intenção didática de Brecht vai, a cada peça, encerrando o ciclo do teatro didático que o dramaturgo havia iniciado com $O$ voo de Lindberg (1929). O que se pode dizer é que suas peças continuam conscientemente pedagógicas, mas não essencialmente didáticas (Bornheim, 1992), porque as técnicas utilizadas por ele são, então, transformadas. Não se pode negar, de resto, que no conceito de distanciamento está inserido o caráter pedagógico - afinal, provoca-se o afastamento do espectador justamente para que ele apreenda a realidade e aprenda com ela.

Se o espírito crítico despertado no público não exclui a possibilidade de provocar também a emoção, como vimos, o mesmo acontece com a caracterização do teatro como um meio de diversão. Segundo Willett (1967), o teatro épico passa a ser justificado como entretenimento (diversão) por Brecht depois que o dramaturgo escreve a peça Vida de Galileu (1938-1939). A partir de então, Brecht começa a interpretar sua própria obra mais em termos científicos que políticos, registrando, aliás, suas ideias nessa direção em seu 
ensaio "Pequeno órganon para o teatro" (1948), considerado por alguns críticos e teóricos uma síntese ou plataforma da teoria do teatro épico.

Emoção e diversão são, portanto, reações, ligadas ao prazer estético, admitidas na teoria teatral de Brecht, para quem o teatro tem como função divertir: "O teatro consiste na apresentação de imagens vivas de acontecimentos passados no mundo dos homens que são reproduzidos ou que foram, simplesmente, imaginados; o objetivo dessa apresentação é divertir" (Brecht, 2005, p.127, grifo do autor). A diversão da qual fala o dramaturgo está intrinsecamente relacionada ao espírito da crítica científica, porque o público é o da era científica e "exige um tipo de entretenimento que reflita a visão moderna e científica da realidade" (Carlson, 1997, p.379). $\mathrm{O}$ valor dado ao divertimento como um objetivo essencial do teatro liga-se àquele sentimento de surpresa-que Anatol Rosenfeld (2006) aponta nos gregos - diante da descoberta, do conhecimento, e também demonstra a preocupação de Brecht (2005, p.67) em defender o teatro épico de ser julgado como "profundamente desagradável, tristonho e fatigante", o que certamente não interessaria a nenhum público.

As condições necessárias ao palco e à sala de espetáculos, para se alcançar o efeito de distanciamento, indicam que não se deve produzir nesses espaços nenhum clima de magia, nenhum "campo de hipnose", nenhuma forma de ilusão, e "a propensão do público para se entregar a uma tal ilusão deve ser neutralizada por meios artísticos” (idem, p.104); são esses meios artísticos, desenvolvidos por meio de determinadas técnicas, que vão caracterizar a encenação épica.

Para tratar do Verfremdungseffekt, precisamos ter em conta alguns pressupostos extraídos dos textos teóricos de Brecht sobre as técnicas de distanciamento, lembrando que "as próprias técnicas têm um significado simbólico próprio, elas são apenas meios para se atingir um fim" (Jameson, 1999, p.64). 
A responsabilidade da encenação épica para Brecht recai principalmente sobre a atuação do ator, que precisa trabalhar um determinado tipo de representação a fim de alcançar o distanciamento. Além das técnicas desenvolvidas para o ator, há também outros recursos recomendados pelo dramaturgo que contribuem para a caracterização da cena épica.

As duas primeiras partes que propomos a seguir para a abordagem dos pressupostos do teatro de Brecht são, ao fim e ao cabo, apenas para demarcar dois trabalhos que se assemelham e se completam nas formas de teatralização; a terceira parte, por sua vez, procura definir e caracterizar a fábula brechtiana. Sem querer traçar aqui uma comparação reducionista entre Brecht e os dramaturgos portugueses, apenas afirmamos que a fábula desenvolvida tanto por Cardoso Pires quanto por Sttau Monteiro, guardado o estilo de cada autor, aproxima-se das características que apontamos na definição da fábula brechtiana.

\section{Encenação épica: o ator mostra o teatro, o espectador analisa a realidade}

Em sua teoria do teatro épico, Brecht dedica especial atenção à atividade do ator e descreve detalhadamente o trabalho que este deve desempenhar para resultar a representação épica que é determinante para o alcance do efeito de distanciamento. Segundo Brecht (2005, p.50), o ator da cena épica "deverá esforçar-se para que o espectador reconheça nele um intermediário entre si e o acontecimento". É, portanto, principalmente a partir do trabalho proposto ao ator que as técnicas de distanciamento são desenvolvidas e atingem seus objetivos.

A atuação do ator descrita por Brecht em seus ensaios sobre estética teatral, como sempre, provém do trabalho 
prático, de uma série de exercícios realizados durante os ensaios das peças. Bornheim (1992, p.275) afirma que não se pode falar de uma teoria brechtiana do ator; no entanto, "o trabalho do ator funciona como uma espécie de portal de acesso a questões essenciais de todo o teatro de Brecht". Em suas notas sobre peças e encenações, Brecht descreve a atuação de seus atores, e tal descrição funciona em seus textos não apenas como ilustração, mas como fundamentação para sua teoria.

$\mathrm{O}$ ator ideal do teatro épico deve ter uma visão essencialmente crítica da realidade, "e mais ainda, tal crítica deve fazer-se no presente do trabalho artístico do ator - e é dentro desse contexto que surge o cultivo do distanciamento" (idem, p.261). Assim, exige-se do ator o mesmo posicionamento crítico que o teatro épico quer despertar no espectador.

Na prática, Brecht propõe um intenso trabalho teatral ${ }^{10}$ antes dos ensaios e, por parte do elenco, uma concentrada leitura da peça de modo que os atores entendam que, mais que decorar frases, o importante é fixar as partes do texto que chamam a atenção, assumindo, com isso, uma atitude de surpresa e, ao mesmo tempo, de contestação diante dos acontecimentos narrados (Brecht, 2005).

Além dos escritos teóricos, encontramos também nos poemas de Brecht referências à arte de representar. O poema

10 Referimo-nos à explicação e à definição dadas por Pavis (2007, p.412, grifo do autor) ao trabalho teatral: "Este termo - talvez uma tradução inconsciente do Modelbuch brechtiano que leva o título de Theaterarbeit (1961) - teve nos anos cinquenta e sessenta uma grande voga, pois evocava não só o estrito trabalho dos ensaios e do aprendizado do texto pelos atores, mas também a análise dramatúrgica, a tradução e a adaptação, as improvisações gestuais, a busca do gestus, da fábula ou a abertura do texto a uma pluralidade de sentidos, a marcação dos atores, a preparação dos figurinos, dos cenários, das luzes etc. Trabalho teatral implica assim uma concepção dinâmica e operatória da encenação". 
"O mostrar tem que ser mostrado" praticamente explica e sintetiza um exercício de atuação:

Mostrem que mostram! Entre todas as diferentes atitudes

Que vocês mostram, ao mostrar como os homens se portam Não devem esquecer a atitude de mostrar.

A atitude de mostrar deve ser a base de todas as atitudes.

Eis o exercício: antes de mostrarem como

Alguém comete traição, ou é tomado pelo ciúme

Ou conclui um negócio, lancem um olhar

À plateia, como se quisessem dizer:

Agora prestem atenção, agora ele trai, e o faz deste modo.

Assim ele fica quando o ciúme o toma, assim ele age

Quando faz negócio. Desta maneira

O seu mostrar conservará a atitude de mostrar

De pôr a nu o já disposto, de concluir

De sempre prosseguir. Então mostram

Queoquemostram, toda noitemostram, jámostraram muito E a sua atuação ganha algo do fazer do tecelão, algo

Artesanal. E também algo próprio do mostrar:

Que vocês estão sempre preocupados em facilitar

$\mathrm{O}$ assistir, sem assegurar a melhor visão

Do que se passa - tornem isso visível! Então

Todo esse trair e enciumar e negociar

Terá algo de uma função cotidiana como comer,

Cumprimentar, trabalhar. (Pois vocês não trabalham?) E

Por trás de seus papéis permanecem

Vocês mesmos visíveis, como aqueles

Que os encenam.

(idem, 2000, p.241)

$\mathrm{Na}$ cena, o ator deve mostrar-se ator e esta atitude de tudo mostrar, além de ser a condição necessária para a produção do efeito de distanciamento, é responsável por eliminar a noção de quarta parede - que separa ficticiamente o palco da plateia e da qual advém o efeito de ilusão -, impedindo o ator de produzir o efeito da empatia. 
Ao assumir essa atitude de desvendar os mecanismos da interpretação, o ator - assim como também a encenação como um todo - lembra ao público que ele (espectador) está no teatro. Nas palavras do ensaísta português Mario Vilaça (1966, p.274):

Tudo [na encenação épica brechtiana] é teatro. O espectador tem de sentir que está realmente no teatro e que tudo que ali se passa é apenas representação. Ao sair, não deverá sentir-se emocionalmente satisfeito, mas, sim, intelectual e socialmente insatisfeito.

Todos os propósitos da atuação épica convergem para o mesmo objetivo que é o de o ator atuar de "forma que se veja, tanto quanto possível claramente, uma alternativa, de forma que a representação deixe prever outras hipóteses e apenas apresente uma entre as variantes possíveis" (Brecht, 2005, p.106); por isso, o ator em cena não chega nunca a se transformar completamente na personagem que representa, porque, na verdade, é como se sua atuação no palco estivesse fazendo uma proposta. Nesse sentido, para uma representação épica, que não deve pretender a metamorfose total e integral do ator na personagem, Brecht (idem, p.107) sugere "três espécies de recursos para distanciar a expressão e a ação da personagem apresentada: 1. recorrência à terceira pessoa. 2. recorrência ao passado. 3. intromissão de indicações sobre a encenação e de comentários". A recorrência ao passado permite ao ator a "retrospecção das falas", distanciando-as, sendolhe possível, com essa atitude distanciada, pronunciar-se sobre qualquer fala. Os recursos 1 e 3 se completam porque tal "intromissão" geralmente se faz na terceira pessoa, possibilitando ao ator comentar uma situação e/ou fazer indicações da própria encenação. Em algumas passagens de seus textos teóricos, Brecht afirma que a recorrência a 
tais recursos se dá nos ensaios e também pode ocorrer na apresentação do espetáculo.

Em seus registros, Brecht descreve a representação da atriz Helene Weigel na encenação de A mãe - peça inspirada na obra homônima de Máximo Gorki (1868-1936) - como exemplo de interpretação do ator em uma encenação épica. Brecht inicia suas notas definindo a peça:

A mãe, escrita no estilo das peças didáticas, mas exigindo atores, é uma peça de concepção dramática antimetafísica, materialista, não aristotélica. Essa arte dramática não explora, tão decididamente como a arte dramática aristotélica, a tendência que há no espectador para uma empatia por abandono; revela, além disso, uma atitude essencialmente diversa, em relação a determinados efeitos psicológicos, tal como, por exemplo, a catarse". (idem, p.47, grifo do autor)

No papel de Pelagea Wlassowa, Helene Weigel profere sua fala, segundo Brecht, como se fosse na terceira pessoa, expõe a personagem diante do espectador "como agente e como objeto da reflexão". Em determinados momentos a atriz pronuncia as frases em voz alta; em outros, em voz clara, categórica, e prolonga, por exemplo, o som da palavra "sim" em tom de falsete, e Brecht sintetiza: "Era como se estivesse representando para uma roda de políticos - sem que por isso fosse menos atriz ou saísse dos domínios da arte" (idem, p.53).

Anatol Rosenfeld (2006, p.161) define claramente as funções do ator da representação épica brechtiana que, com o objetivo de interromper ou eliminar qualquer processo de ilusão - ou seja, o processo catártico -, deve mostrar a personagem:

Em cada momento [o ator] deve estar preparado para desdobrar-se em sujeito (narrador) e objeto (narrado), mas também para "entrar" plenamente no papel, obtendo a 
identificação dramática em que não existe a relativização do objeto (personagem) a partir de um foco subjetivo (ator). [...] Na medida em que o ator, como porta-voz do autor, se separa do personagem, dirigindo-se ao público, abandona o espaço e o tempo fictícios da ação.

O ator-narrador, ao se dividir em "pessoa" e "personagem”, toma uma posição frente aos fatos apresentados e em face da personagem, assumindo ele (o ator) o ponto de vista da crítica social (idem). Para Brecht, o ator não abandona nunca o papel de narrador e é nesse momento que, em seu desempenho, cabe perfeitamente o uso da terceira pessoa. Ao apresentar a personagem como se estivesse descrevendo alguém que lhe é estranho - e aqui poderá empregar a terceira pessoa-, o ator não deve se esquecer de que quem está em cena não é a pessoa descrita, mas a que descreve, e suas opiniões (do ator) não estão em sintonia com as de quem é descrito. Jameson (1999, p.85) comenta que a representação em terceira pessoa ratifica a natureza "imaginária" do eu e o mantém a distância no palco.

Para explicar o papel do narrador na encenação épica, Brecht se vale da narração dos acontecimentos que podem ocorrer em qualquer esquina de rua. As cenas de rua, ${ }^{11}$ para o dramaturgo, são o exemplo-padrão da encenação épica em que o indivíduo que descreve e narra a cena interrompe-a com explicações e comentários de tal forma a distanciar o acontecimento narrado:

11 Brecht (2005, p.90) recorre a acontecimentos que podem se desenrolar em qualquer esquina de rua, por exemplo: "a testemunha ocular de um acidente de trânsito demonstra a uma porção de gente como se passou o desastre". Segundo ele, esseé um exemplo de teatro épico na sua forma primitiva e explica que a cena de rua estabelece, pois, uma afinidade com esse tipo de teatro. No seu ensaio "As cenas de rua - Esquema de uma cena de teatro épico”, a partir do exemplo citado, Brecht explica a forma de representação épica. 
A transcrição direta da representação ao comentário, que caracteriza o teatro épico, é o elemento que logo à primeira vista encontramos numa descrição levada a efeito na via pública, seja ela qual for. O indivíduo que efetua a descrição na via pública interrompe com explicações, tantas vezes lhe pareçam convenientes, a sua imitação. (Brecht, 2005, p.98)

Quanto mais for interrompido aquele que narra (atua), mais claramente percebemos seu gesto, por isso "la interrupción de la acción ocupa el primer plano en el teatro épico" (Benjamin, 1987, p.19). A partir do momento em que o ator passa a reparar em seu próprio gesto e a realizá-lo cuidadosamente, realça a importância do acontecimento narrado, dando-lhe notoriedade e provocando, então, o distanciamento do espectador.

Assim, vinculada ao trabalho do ator está uma determinada linguagem gestual ou, como escreve Brecht, em latim, o gestus, que, na forma de o ator mostrar-se como tal, isto é, como ator, exibe suas atitudes em cena, assume uma posição. $\mathrm{O}$ ator mostra seu próprio gesto, destacando-o, como em uma moldura, de modo a obrigar o espectador a nomear o gestus executado, dando-lhe uma significação elevada. Esse gestus do qual fala Brecht é diferente daquele gesto convencional, conhecido do público, como, por exemplo, um movimento de cabeça para dizer sim ou não. O gestus, na realidade, 'é 'vago', desconhece a convenção prefixada, ou só poderia aceitá-la acidentalmente, e o que está em causa nele é o próprio sentido ou a intenção básica do espetáculo" (Bornheim, 1992, p.284). Podemos dizer que o gestus adquire uma particularidade de caráter social quando representa uma realidade essencial ou uma providência assumida; é, então, "significativo para a sociedade, que permite tirar conclusões que se apliquem às condições dessa sociedade" (Brecht, 2005, p.238). Assim, identificado como social e histórico, o gestus se desvincula 
de uma natureza humana eterna e de uma caracterização arquetípica: ${ }^{12}$

o gestus envolve claramente todo um processo no qual um ato específico - na verdade, um ato particular, situado no tempo e no espaço e vinculado a indivíduos concretos específicos - é assim identificado e renomeado, associado a um tipo mais amplo e mais abstrato de ação em geral, e transformado em algo exemplar (mesmo porque a palavra arquetípico não nos interessa mais). (Jameson, 1999, p.143, grifo do autor)

A exteriorização do gesto é algo extremamente complexo, pois implica as atitudes que as personagens exibem umas em relação às outras. Para o trabalho do ator, é-lhe sugerida a arte da observação de material gestual colhido da realidade: na vida cotidiana, nas cenas de rua, nos meios de comunicação. Um exemplo desse tipo de observação, que pode formar o repertório dos atores, é fornecido por Willi Bolle (1986), que apresenta a descrição de uma cena da peça Mãe Coragem e seus filhos na qual a gestualidade da atriz Helene Weigel - elaborada por meio da observação de uma foto de imprensa em que uma mulher aparece curvada ao lado do filho morto, durante o bombardeio de Cingapura - e a expressão de dor de Mãe Coragem pela perda do filho remetem à cena da foto: "O ato da mimese, realizado pelo ator segundo um original, corresponde a um processo de pensamento - um pensamento corporal, pois a aprendi-

12 Jameson (1999, p.143) faz, em nota, uma distinção entre a terminologia nada brechtiana dos tipos e do típico e seu uso lukacsiano: “em Lukács o ‘típico’ opera principalmente como uma categoria classificatória de personagens - uma restrição que claramente confina o grande crítico húngaro a um realismo bastante tradicional com seus sujeitos estáveis e psiques centradas. O que é 'típico' no gestus brechtiano é a própria ação, e também [...] os vários componentes ou elementos de construção da ação, irreconhecíveis daqui por diante: aqui o sujeito estável e reconhecível sai de cena". 
zagem do ator consiste em transmitir o gestus a seu corpo inteiro" (idem, p.27). Dessa forma, o gestus está também relacionado à expressão do corpo, objetivando a percepção do todo por meio de detalhes significativos.

Na prática brechtiana, muito do que se construiu sobre o teatro épico foi sendo desenvolvido durante os ensaios, com os exercícios de representação propostos por Brecht. Em carta a um ator ${ }^{13}$, Brecht acentua, entre outros temas, a importância da qualidade artística, de saber falar com clareza, de utilizar o dialeto do povo, e explica sua exigência de o ator não se transformar na personagem. Para isso, o dramaturgo critica a forma naturalista de representação, na qual "floresceu o princípio absolutamente estéril de que 'compreender tudo é tudo perdoar"”, e em seguida descreve o trabalho do ator segundo uma "nova orientação":

Tem [o ator] de tomar posição, intelectual e emocionalmente, em relação às personagens e às cenas. A nova orientação que se exige do ator não é uma operação fria, mecânica; o que é frio e mecânico não se coaduna com a arte, e esta nova orientação é, justamente, de natureza artística. Se o ator não estabelecer uma autêntica ligação com o seu novo público, se não tiver um interesse apaixonado pelo progresso humano, essa nova orientação não poderá concretizar-se. (Brecht, 2005, p.254)

Fica evidente que a representação épica exige do ator uma tomada de posição frente aos acontecimentos, certamente a mesma que se exige do espectador do teatro épico diante da cena apresentada. ${ }^{14}$

13 "De uma carta a um ator" é a resposta de Brecht a um ator que pergunta se a exigência de que o ator não se transforme totalmente na personagem não torna "a representação um acontecimento puramente artístico, mais ou menos desumano” (Brecht, 2005, p.253).

14 Jameson (1999) aventa a possibilidade de se pensar que o ator talvez 
É de responsabilidade do ator mostrar no palco suas atitudes revestidas de um gestus sobrepessoal, por isso social, oferecendo assim, ao espectador, motivos de reflexão. Nessa relação entre o que o ator mostra e comenta e o que o espectador assiste e analisa se realizam o princípio e o objetivo da cena épica.

Toda a teoria brechtiana de teatro, como temos reiterado, pressupõe a representação cênica: "É a encenação que dará a aplicação total à concepção épica, que não é parcelar e se completa no todo constituído pelo teatro, pelos actores e pelos processos usados pelo encenador" (Vilaça, 1966, p.277). Por outro lado, é possível reconhecer a linha brechtiana no próprio texto dramático - haja vista, por exemplo, a dramaturgia portuguesa que aqui nos propomos analisar. Com efeito, é preciso lembrar que as referidas peças portuguesas foram escritas em um determinado contexto em que se privilegiou a construção textual, pois em tempos de ditadura os autores não sabiam se suas peças seriam levadas à cena. Há características específicas de cada uma dessas peças, como veremos, que evidenciam, na dramaturgia portuguesa, um registro das marcas brechtianas de teatro épico, seja pelas indicações cênicas detalhadas, como ocorre em Felizmente há luar!, seja pela composição fundamentalmente narrativa do texto, como ocorre em $\mathrm{O}$ render dos heróis. A propósito, cumpre citar um exemplo, apenas um, de uma didascália, referente à representação do ator, na peça Felizmente há luar!:

Ao dizer isto, a personagem está quase de costas para os espectadores. Esta posiçãoé deliberada. Pretende-se criar desde já, no público, a consciência de que ninguém, no decorrer desta peça, vai esboçar um gesto para o cativar ou para acamaradar com ele. (Sttau Monteiro, 1980, p.14)

seja mais importante que o espectador, por isso devemos pensar no "método" Brecht. 
A análise das fábulas históricas $O$ render dos heróis e Felizmente há luar!, distanciada no tempo e no espaço, é certamente facilitada pela riqueza de detalhes que os textos das referidas obras apresentam. Assim, a nossa leitura dessas peças faz-se tão-somente por meio do texto dramático e, nessa perspectiva, pretende-se afirmar a característica inegável de teatro para ser lido que elas, quase que obrigatoriamente, apresentam devido ao contexto político ditatorial - e, portanto, repressivo - no qual se inserem.

\section{Modos de teatralização}

Além de propor que o ator mostre ao público que está a representar, Brecht utiliza uma série de recursos técnicos que convergem para o mesmo propósito, de modo que "O teatro [épico] teatraliza-se. É disfarce, é fingimento, é jogo" (Vilaça, 1966, p.266). Brecht teatraliza o próprio teatro principalmente por meio do ator, como vimos. Além disso, teatraliza a literatura por meio das narrações e "literariza" a cena ao sugerir a utilização, no palco, de frases escritas em cartazes ou projetadas em tela (Rosenfeld, 2006). Esse processo de teatralização no palco tem certamente por objetivo provocar um olhar reflexivo e distanciado do espectador; é esta, pois, a proposta.

Sendo assim, a inserção de canções (os songs), as formas de narração, a presença de coros, a composição do cenário, que pode ser apenas sugerida e deve estar a serviço da cena, a utilização de recursos gráficos, como cartazes, por exemplo, as projeções de filmes, ${ }^{15}$ são alguns dos exemplos citados por

15 É sabido que essas técnicas, na verdade, foram introduzidas no teatro por Erwin Piscator. É Brecht (1967, p.127) quem explica que, a fim de "dominar pela representação cênica os grandes problemas contemporâneos: luta pelo petróleo, guerra, revolução, justiça, questão racial etc.", surge a necessidade de se fazer uma transformação no 
Brecht. Quando esses recursos são utilizados, o resultado é a composição da cena provida de quebra, como explica Willett (1967, p.220):

As canções e legendas apresentavam-se, indistintamente, como meios deliberados de interrupção da peça, de retirar o vento às velas enfunadas dos atores e de mostrar o verdadeiro mecanismo da obra. Músicos visíveis, luzes visíveis, tinham de ser acompanhados por uma quebra deliberada da tensão e desapontamento do ator.

Mais que provocar uma apreciação estética, o uso, por exemplo, de recursos cênico-musicais surge para aguçar a reflexão do público. A assimilação da música pelo teatro épico brechtiano, ${ }^{16}$ além de estar vinculada ao trabalho do ator - que assume também a tarefa de cantar -, constitui um modo de teatralização. Nas "Notas sobre A ópera de três vinténs", o dramaturgo explica: "o ator não só precisa cantar, como também mostrar ao público que está cantando" (Brecht, 2005, p.42), e os músicos estão igualmente à mostra durante o desempenho do ator que canta, ou seja, a orquestra está o tempo todo no palco. Novamente, na encenação épica, vemos a importância do ato de tudo mos-

palco. Piscator recorre a invenções e inovações, como, por exemplo, a utilização do filme, a reprodução de estatísticas, a inserção de slogans. Assim "o teatro ambicionava colocar seu parlamento (o público) em condição de tomar decisões", e, conclui o dramaturgo alemão, "o ponto de vista estético estava inteiramente subordinado ao ponto de vista político" (idem, p.128).

16 A obra dramática de Bertolt Brecht está toda ela vinculada à música, os chamados songs. O dramaturgo conseguiu realizar muitas das suas aspirações musicais a partir das parcerias com os compositores Edmund Meisel, Kurt Weill, Hanns Eisler, Paul Dessau, Rudolf Wagner-Regeny. John Willett (1967) traça um histórico da relação de Brecht e seu teatro com a música, menciona a parceria do dramaturgo com os compositores citados e comenta algumas das peças musicais compostas para a obra dramática do dramaturgo alemão. 
trar; podemos dizer que se trata, pois, do gesto ostensivo da demonstração.

Para Brecht, a música de Hanns Eisler para as cenas de Vida de Galileu é um exemplo, pois "revela como a plebe deu às teorias astronômicas do sábio um novo teor revolucionário" (idem, p.163). Assim, a música também tem como propósito adotar uma atitude em relação aos acontecimentos narrados, podendo se manifestar de várias formas, desde que mantenha sua independência. A música tem a intenção da provocação e da denúncia, confere ao atorcantor a possibilidade da representação de gestos essenciais e ao espectador a oportunidade de análise crítica. Assim, ao assumir um posicionamento político e adotar uma atitude em relação aos temas, a música, ao mesmo tempo, elimina qualquer encantamento por parte do público e permite ao espectador a reflexão. Por isso, na execução da canção pelo ator também está contido o gesto social:

Identicamente [à música, em Vida de Galileu] em O círculo de giz caucasiano, o modo frio e indiferente com que o cantor canta, ao descrever o salvamento da criança pela criada, apresentado no palco sob a forma de pantomima, põe a nu todo o horror de uma época em que a maternidade pode transformarse em fraqueza suicida. (ibidem, )

Anatol Rosenfeld (2006, p.160, grifo do autor) observa que as canções podem ser dirigidas diretamente ao público - um dos recursos mais importantes do distanciamento - ou a outras personagens e "seu gestus é, quase sempre, demonstrativo, apontando com o dedo as falhas do mundo narrado". As canções, por não apresentarem relação direta com a ação, assumem assim a função de interromper a sequência cênica.

As recomendações que podemos extrair do trabalho de Brecht para a composição da encenação épica têm muito 
a ver com a atividade cenográfica defendida por ele. Não se trata de uma mudança de cenário - não desaparece totalmente, nas suas peças, o palco italiano, de maneira que, dessa perspectiva, ele não estaria fazendo nada de novo, pois na história da cenografia muito já se fez fora do palco italiano -, o espaço é o mesmo - "o espaço é o mundo", explica Bornheim (1992) -, o que ocorre é uma modificação na maneira de utilização desse espaço. Brecht sugere a utilização de esteiras rolantes no lugar do chão, projeções em tela de cinema no fundo do palco, transformação do teto, uso do espaço da plateia como espaço de atuação. O ambiente cênico, por abarcar essa profusão de elementos, transforma-se em espaço de movimento. Com isso, a ideia é a de tornar o espaço cênico mais flexível, tarefa delegada ao que Brecht chamou de "construtor de cena". ${ }^{17}$

Um dos grandes colaboradores de Brecht foi o cenógrafo Caspar Neher, por quem o dramaturgo nutria grande respeito e admiração e cujo trabalho considerava uma verdadeira obra de arte. Os registros de Brecht sobre o trabalho de Neher apontam para determinados recursos utilizados pelo cenógrafo que ajudam a compreender a composição do espaço cênico defendida pelo dramaturgo. Segundo Brecht (2005, p.243), Neher fazia, antecipadamente, esboços e desenhos de seus arranjos cênicos, que eram sempre compostos em pleno acordo com o que pretendia a peça:

E não há, no seu cenário, edifício, corte, oficina ou jardim que não denotem também a marca dos homens que os habita-

17 A ideia de cenógrafo é redimensionada pela introdução do "construtor de cena" - Bühnenbauer -, cujo trabalho, como sempre, não deve propiciar na cena o efeito de ilusão (Bornheim, 1992). Cabe também ao construtor de cena - em conjunto com o diretor, o dramaturgo, o músico e o ator - manter na associação das artes a individualidade de cada uma delas. Nesse sentido, Brecht procura pôr em prática sua negação do conceito wagneriano de obra de arte total. 
ram ou que os construíram. Não só a aptidão e o conhecimento do ofício dos construtores, como também os hábitos dos habitantes, se tornam, desta forma, patentes a todos.

A ideia de arranjo cênico é a de que o cenário apresente condições para incorporar elementos narrativos, já que o palco do teatro épico tem como principal característica narrar os acontecimentos. Como se sabe, no teatro a narração é o recurso que elimina a quarta parede e também põe à mostra a construção teatral. Se o ator se mostra como tal, o palco faz o mesmo: avisa o tempo todo que se trata de teatro, ou seja, não cede de forma alguma ao ilusionismo cênico. Assim, uma mudança de cenário, por exemplo, pode ocorrer à vista dos espectadores e pode ser executada pelos próprios atores; a orquestra, como já referimos, permanece o tempo inteiro presente no palco e não em outro lugar, distante da encenação; as fontes de luz também ficam à mostra. $\mathrm{O}$ ambiente cênico se apresenta, pois, em constante movimentação, de modo a possibilitar uma detida atenção do espectador.

Entre os recursos apontados por Brecht, para que o palco seja um espaço da narração, estão as projeções e os títulos nas cenas. Esses elementos realçam o ambiente dos homens e contribuem para a exata compreensão dos acontecimentos.

Como exemplo de cena épica, o dramaturgo descreve a importância da projeção em $A$ mãe que teve cenário de Caspar Neher:

Numa grande tela de fundo, projetavam-se textos e documentos fotográficos que permaneciam durante as cenas, de forma que a projeção adquiria um caráter de bastidor. A cena indicava, assim, não só um espaço real (por meio de alusões), mas também (por meio de textos e documentos fotográficos) o vasto movimento ideológico em que decorriam os acontecimentos. Em caso algum, as projeções são um simples expediente mecânico, um complemento; não constituem "ardis", 
não significam um auxílio para o espectador, antes lhe são antagônicas, pois fazem gorar todo e qualquer impulso de empatia e interrompem o seu mecânico deixar-se levar. São, por conseguinte, elementos orgânicos da obra de arte que tornam o seu efeito mediato. (idem, p.48, grifo do autor)

As projeções de textos em tela formalizam a comunicação direta com o público, exigindo do ator uma nova postura, uma outra forma de atuação. No momento em que tal recurso é utilizado, a ação é submetida a uma crítica que advém do distanciamento que a cena, em seu conjunto, possibilita.

O mesmo efeito provocado pelo uso de projeções ocorre quando da utilização de títulos nas cenas, que no palco podem aparecer também projetados em tela ou simplesmente escritos em cartazes e letreiros. Os títulos narrativos aparecem para enquadrar uma cena ou intitular uma canção e também assinalam e registram a cronologia da história maior. Podem ainda ser mediadores entre a história maior e a história da experiência individual ${ }^{18}$ (Jameson, 1999); nesse sentido os títulos acatam "outra recomendação típica de Brecht, a de contar a história da experiência individual como nos livros de história" (idem, p.71). Para Brecht (2005, p.160), a peça apresenta uma estrutura própria: a de "uma pequena peça dentro da peça”, na qual devemos contrapor as diversas partes constituintes da fábula. Para chegar a isso, a melhor maneira é a utilização de títulos, que

devem conter flechas certeiras, dentro de uma perspectiva social, e explicitar, simultaneamente, algo acerca da forma de representação desejável, isto é, devem imitar, consoante o

18 Em Mãe Coragem e seus filhos, por exemplo, a história maior é a Guerra dos Trinta Anos e a história menor refere-se aos destinos a que Mãe Coragem e seus filhos estão condenados (Jameson, 1999). Simplificando, a história maior é a dos "livros de história" e a menor é a da experiência individual. 
caso, o estilo do título de uma crônica, de uma balada, de um jornal ou de um quadro de costumes. O tipo de representação a que os usos e os costumes são comumente submetidos suscita facilmente o efeito de distanciamento.

Os títulos e projeções de textos conferem à encenação um caráter literário e, embora estejam incorporados à cena, não pertencem diretamente à ação nem a ela se contrapõem, possibilitando uma visão estática da situação, uma vez que esses textos representam uma oposição ao movimento da ação; éo contraste que provoca a distância necessária à crítica.

Barthes (1999, p.130) ressalta que Brecht "nos propõe não somente uma obra, mas também um sistema, forte, coerente, estável, difícil de aplicar", e sabemos que tal sistema ou método corre o risco de ser banalmente simplificado, pois, como adverte Mário Vilaça (1966, p.268), "a simples utilização da técnica épica não prova que o encenador consiga atingir os fins a que o teatro épico se propõe" - isso, aliás, vale tanto para a encenação quanto para a dramaturgia.

Por enquanto, podemos afirmar que a peça de José Cardoso Pires e a de Sttau Monteiro, que analisaremos a seguir, revelam marcas do teatro brechtiano, pois não perdem de vista o contexto sociopolítico em que foram escritas, estando, portanto, a narrar, de forma alegórica, os acontecimentos da realidade. Quer-se dizer com isso que são peças cuja qualidade estética é sustentada pelas ideias de teatro de Brecht e por isso e além disso representam uma dramaturgia que resistiu às mais graves adversidades.

\section{A fábula brechtiana}

É marcante a importância que o dramaturgo alemão dá à fábula, tal como o filósofo grego que ele, Brecht, em outros assuntos contesta: 
Quanto ao estilo de representação, concordamos com Aristóteles quanto a considerar a fábula o cerne da tragédia, mas discordamos dele no que respeita ao objetivo a que deve obedecer a sua representação. A fábula não deve ser um mero ponto de partida para toda espécie de digressões no domínio da psicologia ou em qualquer outro; deve, sim, conter tudo em si, e tudo deve ser feito em função dela; basta narrá-la para que todos os acontecimentos nela contidos se efetivem. (Brecht, 2005, p.212)

Do conceito de fábula na obra teatral, podemos depreender, segundo Pavis (2007, p.157), duas concepções: "como material anterior à composição da peça e como estrutura narrativa da história" - nesta segunda concepção, a fábula seleciona os episódios das cenas e textualiza ações que ocorreram fora da peça.

A fábula, no sentido brechtiano, não é simplesmente o enredo da peça - extraído da vida tal como poderia ser na realidade -, mas a concepção que o autor tem da sociedade na qual ele vive. A fábula épica brechtiana desvela as contradições do mundo dos homens sem mascarar a incoerência dos acontecimentos narrados, nem esconder a ilogicidade desses acontecimentos. Por isso mesmo, ela se estrutura na falta de continuidade da ação, frequentemente interrompida pela canção, pelo ator que fala diretamente ao público etc. Para Brecht (2005, p.159): “Tudo depende da fábula, queé o cerne da obra teatral. São os acontecimentos que ocorrem entre os homens que constituem para o homem matéria de discussão e crítica, e que podem ser por ele modificados".

A fábula brechtiana apresenta acontecimentos isolados, mas de certa forma interligados e com funções claras, constituindo uma estrutura própria, qual seja, "a de uma pequena peça dentro da peça” - daí a inserção de títulos. A justaposição de cenas aparentemente soltas (Magaldi, 2001) constitui a estrutura utilizada por Brecht em sua dramaturgia, principalmente na fase de maturidade do dramaturgo 
(Mãe Coragem e seus filhos, O círculo de giz caucasiano, Vida de Galileu).

No que se refere aos temas, a fábula do teatro épico aprofunda-se nos problemas sociais. Barthes (1999, p.1301) assinala a convergência entre o pensamento brechtiano e os grandes temas de "nossa" época, a saber:

que os males dos homens estão entre as mãos dos próprios homens, isto é, que o mundo é manejável; que a arte pode e deve intervir na história; que ela deve hoje concorrer para as mesmas tarefas que as ciências, das quais ela é solidária; que precisamos de agora em diante de uma arte de explicação, e não mais somente de uma arte de expressão; que o teatro deve ajudar resolutamente a história desvendando seu processo; que as técnicas cênicas são elas próprias engajadas; que, afinal, não existe uma "essência" da arte eterna, mas que cada sociedade deve inventar a arte que melhor a ajudará no parto de sua libertação.

Compreende-se daí que à fábula brechtiana o que mais importa é a ideia de que o homem é capaz de modificar a história. Por essa razão, talvez, a dramaturgia brechtiana apresente tantos episódios em que o julgamento, o tribunal ( $O$ círculo de giz caucasiano, Vida de Galileu, A alma boa de Setsuan e até Aquele que diz sim, aquele que diz não) aparecem como forma de se fazer compreender didaticamente essa relação mutável que o homem precisa estabelecer com o processo histórico. Para Brecht, o importante não é julgar, mas compreender, como esclarece Touchard (1970), compreender não o homem, mas "o mecanismo humano em seu entrosamento social”; por isso é tão essencial mostrar, narrar, explicar os acontecimentos para que se dê essa compreensão.

Na fábula brechtiana instaura-se a estrutura aberta, ou seja, "que começa com a narrativa e continua com ela por várias cenas” (Bentley, 1991, p.304), sendo que no lugar de 
desfecho há um questionamento, um final inconcluso. Com isso, a personagem épica parece se perpetuar para além da dimensão do palco (Roubine, 2003), istoé, não "morre" real ou metaforicamente no fim da peça, como acontece na tragédia. O exemplo maior de supressão de desfecho conclusivo na obra dramática de Brecht encontra-se em A alma boa de Setsuan, peça em que as últimas palavras de um dos atores que vêm à ribalta apresentar suas desculpas, à guisa de epílogo, falando diretamente ao público, são as seguintes:

Para esse horrível impasse, a solução no momento Talvez fosse vocês mesmos darem trato ao pensamento Até descobrir-se um jeito pelo qual pudesse a gente Ajudar uma alma boa a acabar decentemente...

Prezado público, vamos: busque sem esmorecer!

Deve haver uma saída: precisa haver, tem de haver! (Brecht, 1992, p.185)

De acordo com Walter Benjamin (1987), como o teatro épico procura excluir da cena o "sensacionalismo temático", é preferível à dramaturgia uma fábula antiga a uma fábula nova, de modo que os acontecimentos narrados sejam já conhecidos do público - por isso os temas históricos são os mais apropriados.

Desta perspectiva, José Cardoso Pires e Luís de Sttau Monteiro de fato seguiram a lição de Brecht ao elegerem para suas peças episódios históricos bem conhecidos do público português, como a Revolução de Maria da Fonte e a trajetória do General Gomes Freire - daí serem elas denominadas fábulas históricas. 


\section{3 \\ O RENDER DOS HERÓIS, A FÁBULA histórica de CARDOSO PIRES}

São duas mulheres, uma empunhando a pá do forno, outra a roçadoura na ponta de um longo varapau. Mas a paisagem sinistra, o pavor, o que quiserem, agigantam estas armas a ponto de lhes darem proporções de símbolos, grandes e esguios como lanças de guerreiros. (Cardoso Pires, 1970, p.11-2)

Considerada pela crítica a primeira peça da dramaturgia portuguesa de inspiração brechtiana, O render dos heróis (1960), de José Cardoso Pires (1925-1998), apresenta como matéria histórica a revolta popular conhecida como Maria da Fonte, ocorrida em 1846. A origem da revolta esteve ligada ao descontentamento dos camponeses minhotos com as reformas no sistema tributário e principalmente com a proibição da realização de enterros dentro das igrejas, pois "[...] enterrar cristãos em covas, no descampado, aparecia como uma ofensa sacrílega e um atentado à dignidade humana: era tratar pessoas como se fossem animais" (Saraiva, 1988, p.303). O nome "Maria da Fonte" se deve ao fato de 
um grande número de mulheres ter participado da revolta, tendo os primeiros incidentes ocorrido na freguesia de Fonte Arcada, em Póvoa de Lanhoso (Minho). Comoeram muitas as mulheres que tomaram parte dos motins iniciais, não se sabe a real identidade de Maria da Fonte. A esse respeito, Oliveira Martins (1895, p.194) comenta que "O herói da revolução minhota devia ser uma mulher; não um homem; devia ser desconhecido, lendário: antes um nome do que uma pessoa verdadeira".

De acordo com Oliveira Marques (1998), historicamente, a Revolução da Maria da Fonte teve duas fases: a primeira foi deflagrada pela revolta popular, com duração de apenas um mês (abril-maio de 1846), tendo como resultado a demissão de António Bernardo da Costa Cabral ${ }^{1}$ do Governo; a segunda, chamada Patuleia, bem mais longa e configurada como guerra civil, teve duração de oito meses (outubro de 1846 a junho de 1847), sendo finalizada com a intervenção estrangeira - apoiada pelo governo de Lisboa. O fim da revolta trouxe como consequência o regresso dos Cabrais.

As tensões sociais e as mudanças no contexto político provocadas pela revolta popular constituem o enredo da peça, o qual abrange, no prólogo, a narração dos primeiros motins dos revoltosos; depois, nas três partes seguintes, a propagação da revolta e as consequências políticas e sociais

1 António Bernardo da Costa Cabral, nomeado ministro do Reino pela Rainha em 1842, era o verdadeiro dirigente do Governo, presidido pelo Duque da Terceira. Costa Cabral foi um estadista autoritário e o seu governo "estabeleceu no País um regime de repressão e de violência, embora a imprensa continuasse livre” (Oliveira Marques, 1998, p.40). Segundo Oliveira Martins (1895, p.268), depois da Maria da Fonte e da Patuleia, "Costa-Cabral - o conde de Thomar: era mais que um homem: era um systema e um phantasma”. António Bernardo da Costa Cabral era apoiado por seu irmão, José Bernardo da Silva Cabral, por isso a designação popular de governo dos Cabrais ou Cabralismo. 
do movimento; no epílogo, a interferência estrangeira - de espanhóis e de ingleses -, juntamente com o retorno dos Cabrais figurado na "apoteose grotesca".

A cena de abertura narra o que seria a primeira ação da revolta. Um grupo de mulheres, "esta com filho no colo, aquela arrastando uma cabra”, avança à frente do palco, "atrás delas vêm camponeses de podoa no cinto e arma à bandoleira", até que se ouve um toque de cornetim cada vez mais forte, fazendo-os saltar em fuga desvairada:

$\mathrm{Na}$ noite de quinze para dezesseis de abril um povo dos confins do Alto Minho deixou casas, deixou tudo, e espalhou-se pela serrania bárbara. Fazia luar, um luar negro, se assim se pode dizer. Cá em baixo tudo escuro e torvo: carvalhos velhos, torcidos, carvalhos dos tempos do Dilúvio, urzes e medronheiros pelados e cobertos por uma espécie de ferrugem da terra que lembrava cinza e mundos devastados. Depois o rolar das águas nas profundezas das brechas; depois os fossos de silvedo, os labirintos dos lobos e as bocarras dos desfiladeiros - tudo tornava a noite medonha e traiçoeira.

Um pano negro, a serrania. E diante do pano negro aparecem-nos as primeiras figuras em debandada [...]. Salta a velha do bordão, foge a outra, desvairada, espanta-se a cabra, e não há quem não procure uma saída [...]. (Conta-se que certa mocinha, na ânsia do desespero, se quis lançar a um barranco - isto é: do palco para baixo - e que a muito custo foi salva por aquela multidão tresnoitada que, bem ou mal, sempre conseguiu escapar à ameaça do feroz cornetim). (Cardoso Pires, 1970, p.11-3)

Se não fossem as duas referências ao cenário - "Um pano negro, a serrania" e "do palco para baixo" -, esse texto poderia ser o início de um romance ou conto. Essas duas referências indicam, entretanto, que estamos diante de texto teatral e, ao mesmo tempo, mostram a construção 
da cena ${ }^{2}$ no palco, avisando ao público tratar-se de espaço fictício e, por extensão, de obra de ficção. A caracterização dessa cena de abertura condiz com uma possível função atual do prólogo, que "se presta ao jogo das apresentações que quebram a ilusão e a modalização das narrativas 'encaixadas"” (Pavis, 2007, p.309). Assim, no caso da encenação de O render dos heróis, o prólogo constitui certamente texto de um narrador, apesar de não haver nenhuma indicação na peça de como esse prólogo deve ser de fato encenado. Da mesma forma que o prólogo, todos os outros textos de mesmo caráter narrativo que aparecem geralmente no início de cada parte ou de cada cena podem ser narrados, na encenação, por uma personagem qualquer que assume o papel de narrador.

Nos quadros cênicos seguintes ao prólogo vemos o coronel Inocêncio Matamundos e o sargento Sargentanas em plenos poderes na aldeia do Vilar - onde decorre a maior parte das ações -, na atividade de arrolamento dos bens confiscados e registro de prisão de pessoas que se negaram a pagar os impostos devidos ou a receber à tropa em suas casas. O coronel Matamundos quer saber, por todos e quaisquer meios, a identidade dos "cabeças da revolta" e que tipo de armas usavam. Pela boca das Comadres sabemos que Sargentanas, pressionado por seu superior, coronel Matamundos, e na autoridade de algoz que lhe é atribuída, tortura a velha Maria Henriques - presa por cantar trovas políticas -, a fim de que ela se confesse líder dos motins. Enquanto isso, guerrilheiros encabeçados pelo bacharel Alexandre,

2 Assim também acontece no "antecapítulo" do romance O Delfim, de Cardoso Pires, em que o narrador-autor-personagem nos dá pistas das suas referências para a escrita do romance - anotações de suas conversas com Manuel Palma Bravo e consulta à Monografia do Termo da Gafeira. Se em O Delfim o leitor é convidado a adentrar nos "bastidores da ficção", ao espectador da peça é descortinado o espaço do teatro. 
acampados nas serranias vizinhas, planejam tomar o Vilar. Eles têm o apoio de Maria Ricarda-filha do desembargador Dr. Silveira, um oponente da revolta popular. O ingresso de Maria Ricarda ao grupo de guerrilheiros se deve ao fato de ela ser noiva de um dos revoltosos, o Acadêmico, que anda com seus homens a se bater contra as tropas de Matamundos. Do lado dos guerrilheiros está também o miguelista padre Casimiro, que se dirige ao público e se apresenta como "padre-soldado na militança da justiça". O movimento de revolta cresce cada vez mais e várias aldeias se levantam pela Maria da Fonte.

Percorrendo quase todas as cenas, além das Duas Comadres, está o Cego. Essas três personagens são os principais comentadores e, por vezes, narradores dos acontecimentos. O Cego, personagem essencialmente épica, frequentemente interrompe a sequência cênica com cantos e poemas e se revela Falso Cego na segunda parte da peça: "Tanto vi no mundo que me cansei. Tive que me fazer de cego se quis comer as migalhas dos ricos" (Cardoso Pires, 1970, p.105), diz ele às Comadres, insinuando assim que com a propagação da revolução ele poderia, finalmente, deixar de se fingir de cego.

Um acontecimento ocorrido fora de cena insere na peça um momento de tensão dramática. Trata-se do assassinato do noivo de Maria Ricarda, o Acadêmico. A notícia chega à tropa de Alexandre, no Vilar, deixando Maria Ricarda transtornada a ponto de ela escrever uma carta ao pai, Dr. Silveira, insinuando que cometerá suicídio - mas isso de fato não acontece, como verificamos na primeira cena da terceira parte.

A peça não apresenta linearidade dos fatos, e sim quadros de episódios que narram os acontecimentos. Os diálogos, na verdade, também se propõem a contar e as cenas a descrever e a narrar situações. Na primeira cena da terceira parte, enquanto a baronesa de Stanley, Dr. Silveira 
e Maria Ricarda conversam, um criado entra e substitui o quadro que figura a rainha D. Maria II pela pintura a óleo que representa a cena de São Jorge matando o dragão. A substituição do quadro sugere a fragilidade e o enfraquecimento do poder da rainha devido às revoltas populares que se propagam pelo país.

Depois de decorrido um tempo de aproximadamente três meses de revolta, uma Junta é formada por Dr. Silveira, padre Casimiro, bacharel Alexandre e cavalheiro Stanley para um acordo de pacificação do reino. Há, no entanto, divergências entre eles: Alexandre quer que se garanta o direito dos populares para convencê-los a largar as armas; padre Casimiro vê com desconfiança o novo governo de coligação nomeado pela rainha e se recusa a desarmar seus homens; Silveira e Stanley se aproveitam do movimento popular para salvaguardarem seus interesses próprios de manutenção do poder. Com medo de ser desprezado "por amigos e inimigos, ou seja, ignorado pelo povo e pelos próprios cabralistas", Stanley tem uma ideia fixa: prender Maria da Fonte, quem quer que seja ela, a fim de enfraquecer o partido dos revoltosos. Além do oportunista Dr. Silveira, Stanley consegue levar para o seu partido o padre Casimiro, a quem apresenta Macdonell - segundo Stanley, Macdonell é um representante de D. Miguel, encarregado de nomear o padre "capelão-mor dos exércitos de terra e mar”. Comovido com a nomeação e se deixando levar pela vaidade, o padre Casemiro passa a tomar parte nos piqueniques regados a champanhe e vinho promovidos pelo glutão Macdonell, pelo Dr. Silveira e por Stanley. Nesses encontros eles tramam a prisão de Maria da Fonte, sem nem saber ao certo quem seria ela.

O grupo de Macdonell busca uma mulher qualquer para ser "desmascarada" a Maria da Fonte. Como a velha Maria Henriques acaba por ser morta em decorrência das torturas de Sargentanas, e como Maria Ricarda, apesar de 
ter feito parte da guerrilha, é filha do Dr. Silveira, resta, então, a Maria Angelina. Para os propósitos do grupo de Macdonell, Angelina apresenta as condições ideais, pois se encontra presa na cadeia de Póvoa do Lenhoso, acusada de incendiária, resistência ao fisco, mancebias... Mas os revoltosos invadem a cadeia e a libertam, para desespero de Macdonell, que sai às ruas com seus partidários em busca de uma mulher, qualquer uma, que possa ser apontada como a Maria da Fonte: "Ele [Macdonell] e os do grupo deitam uns tais olhos às camponesas, olhos de quem estuda e escolhe, seguem-nas com tanta atenção que elas, desfilando, voltamse para trás, desconfiadas" (idem, p.229).

Os guerrilheiros, mais uma vez chefiados pelo bacharel Alexandre, tornam a se impor e se reúnem noVilar em marcha de despedida, pois pretendem seguir para Lisboa a fim de fortalecer a revolução. De repente, a Marcha da Maria da Fonte é interrompida pela invasão de tiros e gritos. O Falso Cego percebe imediatamente o que está por vir e volta a se fazer novamente de cego. O Almirante Inglês e o General Espanhol - representantes da intervenção estrangeira, consentida pelo governo português - entram e abrem alas para o cortejo da volta de Costa Cabral, que vem vestido de bode sobre um andor, encerrando assim a peça com a chamada apoteose grotesca.

Cardoso Pires utiliza os recursos propostos por Brecht para a construção de $O$ render dos heróis. Além de narrativa, a peça apresenta títulos, cartazes, palco quase desprovido de cenário, entre outros elementos, como veremos a seguir.

\section{Recursos épico-brechtianos}

Cardoso Pires segue a convenção de escrita de texto teatral com as rubricas destacadas em itálico, mas também introduz, iniciando cenas ou partes da peça, uma série de 
textos narrativos que se sobrepõem em importância aos diálogos das personagens. É, pois, na narração que a peça de Cardoso Pires se estrutura fundamentalmente, já que toda ela é marcada por esses textos narrativos:

\section{Temos outra vez as Duas Comadres.}

Sempre pegadas uma à outra, fazem um par muito especial. Quando menos se espera aparecem. Agora aqui, amanhã acolá, ora a rondarem um povoado qualquer, ora formigando de ponta a ponta dessa serra, por cima de toda a folha.

Pode o mundo girar num torvelinho, pode Lisboa trocar, como troca, mil e um governos de entrudo, que aquelas almas limitam-se a abanar a cabeça e lá vão com o pesado fole - a sua cruz, como diriam depois. Para elas, certa como a luz do meiodia, só uma coisa: o destino de uma Maria Angelina a que o povo chama "a da Fonte". E o resultado está à vista: duas velhas carregando um fole de pólvora. (Cardoso Pires, 1970, p.201)

O caráter narrativo dessa e de outras passagens desse tipo "literarizam" a cena, revelando uma clara aproximação da peça às técnicas do teatro épico propostas por Brecht. $\mathrm{Na}$ encenação épica esses textos narrativos poderão constituir a fala de um ator que "sai" do seu papel de personagem para assumir a função de "narrador”. Duarte Ivo Cruz (2001, p.307) chama essas narrações da peça de Cardoso Pires de "textos de ligação", e explica:

O render dos heróis recria a "Maria da Fonte" e dá-lhe a dimensão épica do movimento popular, que aliás foi. Notase o romancista no detalhe e na limpidez das notas de cena e dos textos de ligação, que devem constituir, na dinâmica do espetáculo, as falas do narrador.

Considerados como parte da encenação - na voz de um narrador ou por meio de um outro recurso com a mesma função, como, por exemplo, a projeção em tela -, esses tex- 
tos de ligação conferem ao espetáculo um caráter literário, comentando a ação e produzindo, deste modo, o efeito de distanciamento brechtiano.

No que se refere ao cenário, $O$ render dos heróis apresenta um principal objeto cênico que é o "pano negro", frequentemente manuseado pelas diferentes personagens à vista de todos: "Sargentanas abre o pano da noite e perfila-se: está apresentada a povoação do Vilar, resumida a um largo do cruzeiro" (idem, p.17). No palco, o elemento cênico que separa a aldeia do Vilar - que se limita à praça ou largo, com um cruzeiro à esquerda e a casa do cura à direita - das vizinhanças e da serrania é um pano negro, objeto metafórico que ora desvenda, ora oculta as ações das personagens. Sargentanas, ao abrir o pano negro, revela a aldeia do Vilar, tomada pelo "reino" do coronel Matamundos que ali manda e desmanda. Cavalheiro Stanley, com o gesto de abrir e fechar o pano negro, revela e oculta o espaço da cena de piquenique onde ele e seus homens confabulam e tramam. Costa Cabral faz "correr o pano sobre o choro de uma criança” e encerra a peça. $\mathrm{O}$ pano negro cumpre, portanto, dupla função: uma, digamos, cenográfica, que define a orientação épica da encenação; outra metafórica, que mostra ou oculta os bastidores do Poder, representado pelas personagens dos exemplos citados. Assim, a aldeia do Vilar, desvendada e ocultada pelo pano negro, concentra em si direta ou indiretamente a representação do espaço onde se institui o Poder e tudo o que ele significa. Da mesma forma que o microcosmo fictício da Gafeira, espaço criado por Cardoso Pires em O Delfim, quer representar o macrocosmo português, como assinala Ana Paula Arnaut (2002) na análise que faz desse romance, assim também a aldeia do Vilar, microcosmo fictício, representa Portugal:

Vilar à letra quer dizer "povoado", pouco mais que um lugarejo. Embora crescido, com regedor, igreja e padre-mestre, juridicamente aldeia, Vilar é um desses lugares abstractos e 
esquecidos do mundo. Não tem correio regular, ao menos de semana a semana, nem largo de feira. Tem um terreiro acanhado, com o competente cruzeiro, onde fazem alto as pobres procissões esfiapadas que, no correr do ano, vão cumprindo o calendário da diocese.

Estamosa vera Praça: pequenae desnudada; um cruzeiroàesquerda, casa do cura à direita. Edisse. (Cardoso Pires, 1970, p.16)

Énesselugar "abstracto" e "esquecido no mundo" que os governantes oprimem o povo; é, pois, noVilar que se instaura a força do Poder representado inicialmente por Matamundos e seus homens, depois pelo retorno dos Cabrais.

No que diz respeito à estrutura da peça, Cardoso Pires insere títulos, legendas e letreiros, assim como canções, coros e recitações - recursos épico-brechtianos que têm como função interromper o fluxo da ação.

Cada uma das três partes da peça é introduzida por um título explicativo - por exemplo, este entre o prólogo e a primeira parte: "Que se passa entre 28 e 30 de abril, nesse mesmo povoado donde partiram os fugitivos e que chamaremos do Vilar e nalgumas serranias não muito longe dali"-, marcando assim uma cronologia histórica, embora as cenas sejam episódicas, pois Cardoso Pires "constrói a múltipla sincronia da temporalidade presente utilizando cortes e elipses entre cenas" (Werneck, 2005, p.226).

Os títulos, no momento em que são inseridos, representam um elemento estático que não pertence diretamente à ação e por isso dela se distancia. Não havendo no texto uma indicação precisa para o aproveitamento desse recurso na encenação, fica em aberto - ou a cargo do encenador - o modo como os títulos serão apresentados no palco.

Um último recurso épico que aqui apontamos é a utilização da canção em $O$ render dos heróis. ${ }^{3}$ Maria Henriques e

3 Hélder Costa (1965, p.231) nos dá um relato sobre a composição 
o Falso Cego são as principais personagens responsáveis por introduzir nas cenas canções cujas letras, geralmente satíricas, apresentam crítica direta ou indireta à situação política:

"Xácara da visita à rainha"

Aprende, Rainha, aprende

Mede agora o teu poder,

Tu dum lado o povo doutro

Qual dos dois há-de vencer.

Se tens armas, não nos temas

Se as não tens, vai procurá-las

Ao brasão dos maus Cabrais

Que tens nele três punhais.

(Cardoso Pires, 1970, p.239)

Com exceção do Falso Cego, as personagens que geralmente se expressam por meio do texto cantado ou recitado são aquelas que de alguma forma estão fragilizadas. Assim, o Soldado-Sentinela de Matamundos canta uma paródia do "Hino da Maria da Fonte" quando Vilar está cercada pelos guerrilheiros; Matamundos canta quando está foragido com Sargentanas pelos campos; os soldados entoam o "Coro dos soldados prisioneiros" - o título do coro já diz tudo; Maria

musical na encenação de $O$ render dos heróis em 1965: "A música foi de Carlos Paredes [...] essa música leve, alegre, popular, não era realmente o que o dramaturgo, encenador e actores queriam dizer? Cremos que sim, e julgamos a colaboração de Carlos Paredes um factor importantíssimo no triunfo conquistado pelo Teatro Moderno de Lisboa".

4 Oliveira Martins (1895, p.179), em seu Portugal contemporâneo, obra que constitui a base histórica para $O$ render dos heróis, cita duas estrofes da "Xácara da visita à rainha", cujos versos não correspondem, no entanto, aos que na peça são cantados pelo Falso Cego. Parece-nos que Cardoso Pires utilizou em sua peça apenas o título da canção citada pelo historiador. 
Ricarda canta quando está de luto e recita quando está presa; Maria Henriques entoa canções "imorais contra as casas da justiça e contra a pessoa dos ministros", no dizer das autoridades, e por isso ela é detida.

Em algumas cenas, a cançãoé interpretada coletivamente: além do "Bendito" - canto religioso - e do "Coro dos soldados prisioneiros", o outro momento é o da execução do "Hino da Maria da Fonte" pela tropa que marcha. Com a chegada dos espanhóis e, em seguida, a entrada do Almirante Inglês, a "'Marcha da Maria da Fonte’ é abafada por toques de clarim e ordens de ataque" e o que se ouve no lugar do hino é uma charanga que toca "O rei chegou", uma referência a Costa Cabral. A intervenção estrangeira - apoiada, como já foi dito, pelo governo português - abafa e reprime a ação coletiva de cantar o hino revolucionário e violentamente elimina qualquer manifestação de oposição ao Poder, pois quando uma "voz perdida" grita "Viva a Maria da Fonte" ouve-se um tiro e o ruído de um corpo que tomba.

Na peça, diferentes funções são atribuídas à utilização da canção, que pode, por exemplo, abrir ou encerrar uma cena, interromper um diálogo, comentar uma situação apresentada. Em todos os casos, a canção sublinha o aspecto narrativo da fábula e suscita o despertar da reflexão crítica por meio do seu conteúdo ou pela forma como se impõe na cena. Segundo a proposta de distanciamento brechtiano, a canção deve ser executada em separado, isto é, destacada, e não se presta simplesmente a um acompanhamento incidental da cena,

[... ela [a canção] se desprende facilmente de dimensões psicológicas, líricas, sentimentais, para assumir um conteúdo objetivo, ligando-se a algo que está acontecendo, ou a um fato, ou a uma tese, ou a uma lição de caráter moral. Por esse caminho, a canção oferece possibilidades didáticas consideráveis. (Bornheim, 1992, p.300) 
Anatol Rosenfeld (2006, p.160) nota que a função da música na estética brechtiana de teatro épico é a de "comentar o texto, de tomar posição em face dele e acrescentar-lhe novos horizontes". Na peça, as canções são dirigidas diretamente ao público ou a outras personagens e ora têm relação direta com a ação, comentando-a, ora não, interrompendo-a.

Dada sua caracterização épica, a peça de Cardoso Pires não concede ao espectador identificar-se com as personagens apresentadas. Os recursos brechtianos que ela adota têm como principais funções colocar à mostra a construção teatral, interromper a sequência cênica e, com isso, quebrar a quarta parede. Os textos narrativos fundamentalmente interrompem os diálogos e comentam situações de modo a despertar o espectador/leitor para a reflexão sobre o que assiste ou lê, tirando-o do "deixar-se levar". Ao espectador de $O$ render dos heróis o mecanismo teatral é inteira e constantemente desvendado pela constituição do cenário, construído ou modificado pelas próprias personagens, desfazendo as possibilidades de efeito de real, lembrando ao público que ele está no teatro.

\section{"Infeliz a terra que precisa de heróis"}

Em $O$ render dos heróis encontramos algumas das personalidades históricas (duque de Palmela, rainha D. Maria II, D. Miguel) que não são exatamente figuradas como personagens presentes na peça, mas são apenas referidas nos diálogos ou aparecem mascaradas e ridicularizadas (António Bernardo da Costa Cabral, José Bernardo da Silva Cabral, duque de Saldanha) na apoteose grotesca. A própria Maria da Fonte - "que nunca ninguém soube ao certo quem teria sido” (Simões, 2004, p.96) - tem a identidade incerta em boa parte da peça, pois há três mulheres que são apontadas pelas outras personagens como sendo 
a que deu nome à revolta popular: Maria Ricarda, Maria Henriques e Maria Angelina.

Com a referência às três Marias da Fonte, Cardoso Pires desfaz ou desmonta a ideia de uma liderança dos primeiros motins da revolução e, ao mesmo tempo, confunde as personagens - e, de certa forma, também o espectador - sobre a identidade de Maria da Fonte. Maria Angelina, Maria Henriques e Maria Ricarda são, pois, "cognomes épicos", assim como os vários nomes pelos quais o narrador do romance $O$ Delfim se refere à personagem Tomás Manuel, como explica o próprio Cardoso Pires (1977, p.165-6):

Identificando o herói por sucessivas designações conferese-lhe um halo paralendário de personagem que simboliza o acontecimento e cria-se uma relação mais crítica do leitor para com a narrativa. As mesmas designações permitem ainda escalonar os tempos de ação (como fez Guimarães Rosa, que foi estoriador de santos e de bandidos sertanejos) ou os alternar e confundir a bel-prazer (como tentou o escritor-furão da Gafeira).

A incerteza das outras personagens, sugerida nas cenas, sobre quem seria a Maria da Fonte alterna-se no decorrer da peça, até que na sétima cena da terceira parte ela é identificada com Maria Angelina. A Maria da Fonte, no entanto, estálonge de ser a personagem central-foco de interessee atenção dos leitores/espectadores - ou a representação do herói mítico, assim como também está ela distante de ser o tema ${ }^{5}$ da peça. O herói mítico, de acordo com Rosenfeld (1996, p.36),

é a personificação de desejos coletivos. Em tempos de crise, esse desejo impregna-se de força virulenta e projeta a imagem

$5 \quad$ Em Felizmente há luar!, de Sttau Monteiro, o general Gomes Freire nunca aparece, mas a trajetória dessa personagem histórica é o tema da peça. 
plástica e individual das esperanças em forma de personificação. Na criação do herói mítico prevalece a crença primitiva de que todos os poderes humanos e naturais podem condensarse numa só personalidade excepcional. Quando em amplos grupos se manifesta a esperança coletiva com intensidade máxima, eles facilmente podem ser convencidos de que só se necessita da vinda do homem providencial para satisfazer todas as aspirações.

Nessa descrição não se encaixa a imagem de Maria Angelina, a da Fonte, pois ela, apesar de fazer parte da guerrilha, não personifica os desejos coletivos; ao contrário, ela está, na realidade, interessada nos papéis que denunciam sua herdade no Brasil. Quando, na cena quatro da segunda parte, ela chega ao Vilar acompanhada pelos guerrilheiros, interpela os soldados e depois o regedor sobre os tais papéis. Assim, ao ser informada de que os documentos foram para a Conservatória da Amoreira, vai imediatamente para lá e resolve seu problema pessoal, incendiando a Conservatória. Trata-se de uma mulher que age com o propósito de resolver um problema pessoal (esconder os documentos que provam sua herança, para não pagar mais impostos ou ter parte de seus bens confiscados; por isso provoca o incêndio no tombo da Amoreira); sua ação é uma reação à imposição que sofre do fisco e não uma ação em prol do coletivo com a anulação do individual. Além disso, a Maria da Fonte pode ser heroína - entendida como personagem central e herói clássico, mítico - no fato histórico, mas não na peça. É nesse sentido que Cardoso Pires exclui a existência de herói ou heróis, apesar do título de sua fábula histórica.

$O$ render dos heróis traz sintetizado no título o que narra a fábula. Nesse quase paradoxo de heróis que são rendidos vemos a revolução completamente reprimida pela aparição das figuras do Poder - ainda que ridicularizadas na apoteose grotesca - que os revoltosos tinham, por algum 
tempo, derrubado. Por isso os versos de Alexandre O' Neill, escolhidos por Cardoso Pires como epígrafe de sua obra, constituem um prenúncio que sublinha e enfatiza o sentido já instaurado no título da peça: "Os heróis são/os heróis vêm/os heróis vão...".

O uso do termo no plural ("heróis") no título da peça traduz um apagamento do indivíduo, já que as personagens ou se definem pelo grupo ao qual pertencem - guerrilhas (bacharel Alexandre, Maria Angelina, Maria Ricarda etc.), tropas (Matamundos, Sargentanas, soldados, Sentinela), junta (cavalheiro Stanley, Dr. Silveira, padre Casimiro, também Alexandre) - ou se duplicam em personalidades semelhantes, como é o caso das Comadres, que são duas, a Primeira e a Segunda, ou em personalidades aparentemente opostas que se alternam, como a do Cego, que se revela Falso Cego e depois cego novamente, um anti-herói que se esconde atrás da falsa cegueira para sobreviver.

Não há como deixar de relacionar o título e a epígrafe, assim como determinadas falas - principalmente do Falso Cego e das Comadres, mas também de outras personagens - às famosas frases da peça Vida de Galileu (escrita entre 1938 e 1939), de Bertolt Brecht: "Infeliz a terra que não tem heróis/Não, infeliz a terra que precisa de heróis".

Em Vida de Galileu, Andrea, assistente de Galileu, espera que o mestre não renegue a doutrina do movimento da Terra em uma sessão da Inquisição: "Andrea gritando Eles não vão ter a coragem! E mesmo se tiverem, ele não vai renegar. 'Quem não sabe a verdade é estúpido e mais nada. Mas quem sabe, e diz que é mentira, esse é um criminoso", (Brecht, 1991, p.150). No entanto, depois de falas eufóricas de Andrea, de Federzoni e do Pequeno Monge, quase certos de que Galileu não renegará a teoria, ouvem-se ecoar o sino de São Marcos e a voz do arauto que lê nas ruas a retratação: "Eu, Galileu Galilei, professor de matemática [...] abjuro o que ensinei: que o Sol seja o centro do mundo, imóvel em 
seu lugar, e que a Terra não seja centro nem imóvel [...]" (idem, p.153). Ao entrar na sala, Galileu ouve Andrea dizer em voz alta: "Infeliz a terra que não tem heróis" e depois os gritos indignados do rapaz, que faz menção de ir embora. Calmo, Galileu pede água e começa a falar: "Não, infeliz a terra que precisa de heróis" (idem, 154).

Abordada pelos teóricos e comentadores, o fato é que o próprio dramaturgo não deixou nenhum registro em que discutisse com profundidade a questão da ausência ou negação da figura do herói. Anatol Rosenfeld (1996, p.48) comenta que nas teorias de Brecht "não tem uma linha no que se refere ao problema do herói”. A afirmação de Rosenfeld é, de certa forma, reiterada por Bornheim (1992, p.241-2), e embora este último afirme que "é sempre dentro da perspectiva da desconstrução que evolui em Brecht a ideia do herói”, admite que o autor alemão "nunca escreveu detidamente sobre esse portentoso assunto". Ao criticar a encenação de Vida de Galileu dirigida por José Celso Martinez Corrêa, apresentada em Portugal em 1975 , o encenador português Mário Sério (1976, p.94) comenta que o Galileu de Brecht é "o anti-herói, o antirresistente e o contrário do culto do super-homem". Concordamos que na obra dramática de Brecht está implícita a negação do herói clássico, mítico e inacessível. Na peça de Cardoso Pires encontramos essa mesma negação do herói mítico, no que se apontaria um fio de diálogo intertextual com a fala do Galileu brechtiano. Como não é nossa intenção e nem propósito fazer aqui um estudo de dramaturgia comparada, apontamos as semelhanças entre as falas do Falso Cego de Cardoso Pires e as de Galileu, com o propósito de analisar seu sentido apenas em $O$ render dos heróis.

Seja nas quadras entoadas pelo Falso Cego, seja nas frases entrecortadas que não constituem um diálogo retilíneo ou contínuo das Comadres, seja nos discursos proferidos pelos representantes do Poder, pela boca de suas personagens, 
Cardoso Pires debate o tema do herói. São diferentes pontos de vista não somente porque são distintas as personagens, mas porque a peça assume a lição de Brecht e estende a reflexão ao público, com a proposta de mostrar ao espectador as várias possibilidades de análise de uma mesma questão, como exige o processo dialético. Por exemplo, o desembargador Dr. Silveira, "cidadão do poder constituído", como ele mesmo se define, em um momento de completa embriaguez declara e pergunta: "E a história todos os dias muda de heróis [...] E hoje? Quem são os heróis de hoje?” (Cardoso Pires, 1970, p.61-2). Sem resposta na cena, a pergunta serve para introduzir o assunto eé ao público que ela indiretamente se dirige. $\mathrm{Na}$ terceira parte da peça, o miguelista cavalheiro Stanley sugere que se desmascare a crendice em Maria da Fonte: "Estamos aqui para destruir heróis, e não para criarmos lendas e vítimas" (idem, p.211). E o afirma categoricamente na primeira pessoa do plural, em nome, portanto, do seu grupo. Na visão deStanley, desmistificando a Maria da Fonte o poder instituído permanecerá garantido. É, no entanto, na penúltima cena da terceira parte que a questão do herói mais enfaticamente se coloca: "Nem no mundo há dois mundos/Nem no céu há dois senhores/Nem existe herói alado/Nem verdade de doutores”, recita o Falso Cego, voltado para o público, abrindo a cena na qual, dentre as três mulheres, Maria Ricarda, Maria Henriques e Maria Angelina, a última será apontada como a Maria da Fonte. Depois da recitação do Falso Cego, o palco inteiro é iluminado e veem-se as três mulheres alinhadas ao fundo, em cenário que representa o cárcere: "ao alto, por detrás delas, três postigos de cárcere desenhados a branco no pano negro da noite-as grades simplesmente" (idem, p.219). É então que o Falso Cego se pronuncia e sua fala nos remete à frase do Galileu de Brecht:

\section{O Falso Cego:}

Guerra que precisa de heróis não é guerra. Partido que pro- 
cura heróis não é partido. (Pausa de quem esgotou um discurso preparado.) Suponhamos um sujeito que abala um belo dia de casa. Abala um belo dia de casa, põe a clavina ao ombro e ligase a outros para fazer a guerra. Assanha-se, vende a pele pelo preço da alma, mata mais ou mata menos - conforme. É isso ser herói? (Nova pausa.) Outro subiu ao alto duns penhascos e vira-se cá para baixo para os companheiros: "Meus irmãos, notem bem no que eu faço! Vejam como eu encaro a morte!" Vem uma bala, zás: leva-o. É isso ser herói? Também não.

\section{Segunda Comadre:}

Tudo porque os heróis não morrem, e tudo porque não pode haver heróis solitários.

\section{Falso Cego:}

Logo, ai do que morre para se fazer de herói [...]. (idem, p. 220-1)

No discurso do Falso Cego há uma crítica explícita à sociedade que precisa de heróis ou mártires que, em prol de uma causa, põem em risco a própria vida. Cabe, no caso, o comentário de Raymond Williams (2002, p.256) sobre a questão do herói na obra dramática de Brecht: "do mesmo modo que é uma sociedade má aquela que necessita de heróis, assim também é uma vida má aquela que necessita do sacrifício". A repetida pergunta "É isso ser herói?" tem já implícita a resposta que, ao fim e ao cabo, nega a existência e a necessidade do herói.

De acordo com Anatol Rosenfeld (1996, p.50), o Galileu de Brecht não é um herói, "já que praticou a ciência como uma espécie de vício, sem nenhum compromisso para com a humanidade”. Concordando com a afirmação de Rosenfeld sobre Galileu, vemos o mesmo acontecer na trajetória da personagem Maria Angelina que, como vimos, também não é heroína. Dentre todas as personagens, o Falso Cego se destaca pela atitude anti-heróica, acentuada no seu discurso há 
pouco citado. Irônico, é ele quem, cantando trovas e poemas, narra e põe em julgamento as ações de outras personagens e, ainda, analisa de forma satírica a situação social e sua própria condição, queé também a de muitos outros. É preciso, então, fingir-se de cego para sobreviver. O Falso Cegoé, na verdade, a representação do anti-herói, pelo seu pensamento e atitude, por também negar categoricamente a necessidade ou existência do herói. Maria da Fonte, na peça, também representa o anti-herói em comparação com a figura mítica da Maria da Fonte "entronizada" nos livros pela história oficial.

Como aponta Maria HelenaWerneck (2005, p.229), José Cardoso Pires tinha como recomendação aos diretores de teatro não encenar $O$ render dos heróis em "estilo heroico":

Deixar de lado o gênero heróico e optar por outra forma, em que tanto caiba o "segredar do medo" quanto elementos satíricos, já se pronunciava como opção estética desde o Prólogo [...]. Por outro lado, anunciando uma prática escritural que recria convenções do gênero revista, José Cardoso Pires pretende enfatizar a narratividade épica da cena em $O$ render dos heróis.

As convenções do teatro de revista se fazem notar especialmente na apoteose grotesca, que apresenta características que se aproximam do distanciamento brechtiano.

A negação do "estilo heroico" está posta na peça desde o título até a composição de personagens anti-heroicas, e é isso que Cardoso Pires, em sua recomendação, espera que se preserve na encenação.

\section{A "apoteose grotesca": satírica e distanciada}

Cardoso Pires buscou nos poemas de Afonso Duarte (1884-1958) e em textos da criação artística popular o ma- 
terial para a composição das canções de $O$ render dos heróis. As trovas que o Cego canta na primeira parte da peça são versos transcritos dos volumes Sibila e Ossadas, de Afonso Duarte. Dos estudos e registros do historiador do século XIX Oliveira Martins (1845-1894) ${ }^{6}$ foi extraída a base histórica de $O$ render dos heróis, peça em que a citação e a alusão são os procedimentos utilizados na composição das canções e, em menor número, das recitações e dos coros de sua fábula histórica. Por meio da linguagem verbal e visual, tais citações e alusões revelam o caráter ideológico da peça, o qual, por sua vez, define uma clara visão de um mundo de opressores e oprimidos, da impotência dos homens frente às forças do Poder.

A caracterização da "apoteose grotesca" é uma alusão às caricaturas das personagens históricas publicadas nos jornais da época, principalmente no "Suplemento Burlesco" de $O$ Patriota. ${ }^{7}$ As características das personagens históricas do andor de Costa Cabral, indicadas na rubrica da cena final, são as mesmas das caricaturas do referido jornal descritas por Oliveira Martins (1895, p.269-70):

O Suplemento Burlesco, em lithographias toscas e caricaturas grotescas, insultava diariamente os Cabraes e a sua gente, mostrando que o antigo genio soez da satyra portugueza não se extinguira. Aqui vinha o Triumpho do Chibo: um bode (o conde

6 O livro Portugal contemporâneo, de Oliveira Martins, os poemas de Afonso Duarte, as contribuições poéticas populares publicadas na imprensa do século XIX e as caricaturas do "Suplemento Burlesco" são informações dadas à parte, isto é, fora do texto da peça, no final do livro $O$ render dos heróis.

7 O Patriota era um jornal de oposição ao Cabralismo e, no seu "Suplemento Burlesco", mostrava frequentemente Costa Cabral travestido de cabra. Cardoso Pires informa que "a figuração da 'Apoteose Grotesca' foi inspirada em caricaturas da época publicadas no 'Suplemento Burlesco' do jornal O Patriota durante o ano de 1847” (Cardoso Pires, 1970). 
de Thomar) com um sacco aos hombros e o letreiro roubo; o chibo sobre um andor que é um cofre, o Thesouro, levado por Saldanha e por José Cabral, o dos conegos, de vestes talares.

A rubrica da peça descreve de forma semelhante o "andor de Costa Cabral":

Entra o andor de Costa Cabral: É uma arca descomunal, a letras garrafais - "ARCA DO TESOURO" - e sustentada por quatro varas. A uma vem Stanley; a outra um sujeito vestido de cônego com uma legenda ao peito - "ZÉ (DOS CÓNEGOS) DA SILVA CABRAL, REI DO NORTE”; à terceira aparece um velho com uma casaca vestida às avessas e um dístico - "SALDANHA" - e, por último, um marreco, todo condecorado com cifrões de lata [...]. Costa Cabral vem no cimo do andor, à sombra de uma grinalda onde se lê: “ANTÓNIO BERNARDO DA COSTA CABRAL". Está vestido de bode, com um rabo terminado em seta como o dos mafarricos; distribui cortesias a torto e a direito. (Cardoso Pires, 1970, p.251-2)

Toda a caracterização da apoteose, pela deformação das personagens e pela movimentação de cortejo oficial aqui tornado ridículo, é a da imagem caricatural da situação política de Portugal em 1847, quando da volta do Cabralismo, mostrando, por meio da sátira, uma crítica aos mecanismos ilícitos do Poder. A cena é constituída pela movimentação do cortejo: "pessoa a pessoa, grupo a grupo, vai-se fazendo vagarosamente o desfile com a imponência das grandes ocasiões" (idem, p.249).

A imponência dos movimentos obviamente contrasta com a forma de trajar das personagens. Instaura-se, pois, a sátira. No grupo não está presente a rainha D. Maria II, mas o General Espanhol trata de gritar um "Viva, la reina! Viva, Portugal!" e um "Viva" de vozes se faz ouvir no palco e fora dele. Além dessa, há apenas mais uma fala do Dr. Silveira 
em tom de quem discursa: "Ordem! Sossego nos espíritos! Sejamos cordatos e saibamos perdoar. Não nos julguemos únicos donos da razão porque em toda parte ela é digna de se encontrar. No palácio do rico como na choupana do pobre" (idem, p.250). No lugar de falas, frases escritas em cartazes carregados pelas personagens, conhecido procedimento brechtiano. O fiscal leva um cartaz no qual está escrito "A lei exige desvelo"; a Baronesa de Stanley leva outro: "Mães agradecidas, só Deus sabe o que sofremos”.

A "cena muda" no final da apoteose - em que as personagens abrem e fecham a boca como se vociferassem ou comentassem, apontando para o Falso Cego com o letreiro ao pescoço "Já vi, agora não vejo" -, torna-se a representação da repressão àqueles que já "viram”, isto é, àqueles que, com a revolução popular, se conscientizaram do regime de repressão do governo, como acontece com o Falso Cego, mesmo que agora pareçam não ver.

No ano seguinte à publicação da peça de Cardoso Pires, em artigo publicado no Diário de Notícias, João Gaspar Simões (2004, p.96) afirmava que "O espírito que preside à concepção de $O$ render dos heróis é satírico”, e relacionava essa característica à matéria histórica retomada na peça:

Não que se utilize nele [espírito satírico] uma sátira à maneira queirosiana, mas a sátira que um "libertino" pode segregar quando por ventura lança mão de um tema em si mesmo tão mitificado que se não pode dizer concretamente onde estão nele os heróis, e o que valem, de facto, como heróis.

Concretizada completamente na "apoteose grotesca", a vertente satírica é, de fato, resultante das formas ridículas e grotescas com as quais são caracterizadas as personagens nas cenas finais: "Em vez de chapéu alto [os pares do reino] trazem panelas enfiadas na cabeça e, à maneira de medalhas, uma quantidade de talheres pendurados. No colar 
da comenda uma perna de frango" (Cardoso Pires, 1970, p.250). A alusão às caricaturas da época, configuradas na "apoteose grotesca", promove, por meio do espírito satírico, o distanciamento do público e, por conseguinte, o despertar da crítica.

Anatol Rosenfeld explica que, na estética do teatro épico, o elemento cômico unido ao didático tem como resultado a sátira. Entre os recursos satíricos utilizados está também o grotesco:

Não é preciso dizer que a própria essência do grotesco é “tornar estranho" pela associação do incoerente, pela conjugação do díspar, pela fusão do que não se casa [...] No grotesco, Brecht se aproxima de outras correntes atuais, como por exemplo do Teatro deVanguarda ou da obra de Kafka. Brecht, porém, usa recursos grotescos e torna o mundo desfamiliar a fim de explicar e orientar. (Rosenfeld, 2006, p.158)

Na figuração da "apoteose grotesca" de Cardoso Pires - na qual as características das personagens se assemelham às máscaras brechtianas ${ }^{8}$ e atingem somente as classes superiores -, o elemento conhecido (a volta dos Cabrais) transforma-se em elemento estranho pela caracterização ridícula das personagens. Essa imagem de estranheza que se forma na cena é ainda enfatizada pelo fato de ser a personagem de Costa Cabral, vestida de bode, a que, ao correr o pano negro, mostra, com esse gesto, o funcionamento do teatro, acentuando, pois, o efeito de distanciamento.

Assim, Cardoso Pires recontextualiza, de forma alegórica, as caricaturas das figuras políticas do século XIX - publica-

8 Anatol Rosenfeld (2006, p.158-9) cita exemplos de caracterizações grotescas nas encenações de Brecht: “[...] os soldados e o sargento de Homem é Homem apareciam como monstros enormes, mediante o uso de pernas de pau e cabides de arame, acrescentados de gigantescas mãos artificiais e máscaras parciais”. 
das na imprensa portuguesa da época - por meio de uma linguagem teatral que produz o mesmo efeito de distanciamento crítico que a sátira implica. Consegue criar, a partir da alusão, uma nova expressão artística para a mesma matéria criticada na contemporaneidade do acontecimento que agora é passado (histórico). 


\title{
4 \\ FELIZMENTE HÁ LUAR!, A FÁBULA hISTÓRICA DE StTAU MonteIRo
}

\author{
De facto, das colinas de Lisboa \\ vê-se arder ao longe a fogueira \\ que consome o corpo do general. \\ E são essas chamas, essas sinistras \\ labaredas, que cento e quarenta e \\ sete anos depois voltam a ser vistas \\ a distância. Quem no-las mostra? \\ Quem no-las faz ver? O autor desta \\ tragédia descarnada e vibrante que \\ chegou ao limiar da arte dramática \\ no momento predestinado para \\ nos apontar as labaredas de uma \\ fogueira que nunca mais se apagará.
}

(Simões, 2004, p.141)

Na esteira de $O$ render dos heróis, de Cardoso Pires, Felizmente há luar! (1961), fábula histórica de Luís de Sttau Monteiro (1926-1993), trata, também de forma alegórica, dos tempos do salazarismo. A peça narra os fatos históricos de Portugal referentes às aspirações liberais que precederam a Revolução de 1820, e conta com o trabalho do leitor/ espectador para fazer uma reflexão sobre os acontecimentos narrados a fim de analisar criticamente o regime político di- 
tatorial de Salazar. Assim, a retomada do episódio histórico é uma forma de falar do passado com vistas à análise do presente. Para tanto, Sttau Monteiro se vale de técnicas do teatro épico brechtiano, compondo um texto em que a narração, as orientações sobre a linguagem gestual dos atores e sobre as intenções das cenas são elementos estruturais e fundamentais para a caracterização épica da peça no sentido brechtiano.

A matéria histórica de Felizmente há luar! é o episódio da Conspiração de 1817. Sob a acusação de conspirarem contra o governo e instituições vigentes, muitas pessoas foram presase 12 delas, depois de processadas e rapidamente julgadas, foram sentenciadas à forca. A peça narra, com efeito, os acontecimentos relacionados à prisão e execução do general Gomes Freire de Andrade (1757-1817), acusado pelos governadores do reino - William Beresford, o Principal Sousa e D. Miguel Pereira Forjaz - de ter sido o líder da Conspiração Liberal. Gomes Freire, que se opunha ao domínio inglês sobre Portugal durante a ausência de D. JoãoVI, foi preso em 1817, com mais outros conjurados, tendo sido enforcado e seu corpo queimado publicamente em Lisboa no mesmo ano. Oliveira Marques (1998, p.15) explica que a execução

teve profunda influência no surto de uma consciência liberal entre o Exército e a burocracia. Longe de evitar futuras rebeliões, apenas serviu para as estimular, uma vez que os opositores ao regime, e com eles muitos outros até então indiferentes, se convenceram da tirania dos governantes e da impossibilidade de conseguir, por meios pacíficos, quaisquer modificações no statu quo.

Dividida em dois atos, a peça é construída principalmente pelo embate verbal entre as personagens que veem em Gomes Freire um aliado do povo, a lutar pelos interesses do povo (o Antigo Soldado, os populares, Sousa Falcão e Matilde de Melo), e as que veem nele um contestador do Poder 
vigente e, por isso, um general perigoso (os governadores do reino e os denunciantes: Vicente, Sarmento e Corvo). $\mathrm{O}$ primeiro ato expõe as maquinações dos governadores do reino que, a qualquer custo, querem nomear um líder para a conspiração liberal da qual ouviram falar. Para isso, contratam verdadeiros espiões - os denunciantes Corvo, Vicente e Morais Sarmento -, a fim de descobrir algum comprometimento. $\mathrm{O}$ anúncio, feito pelos denunciantes, do nome de Gomes Freire aos governadores do reino encerra o primeiro ato. No segundo ato, nomeado Gomes Freire líder da conjura e por isso preso na cadeia de São Julião da Barra, assistimos ao desespero de Matilde, sua companheira, na vã tentativa de pedir aos governadores pela vida do general, cujo fim trágico é narrado nas últimas cenas da peça.

A trajetória de Gomes Freire já tinha sido matéria para dois escritores: Teófilo Braga (1843-1924), que escreveu o drama histórico Gomes Freire (1907), e Raul Brandão (1867-1930), que publicou, em 1914, a sua pesquisa documental Vida e morte de Gomes Freire. ${ }^{1}$ Dessas duas obras, interessa-nos especialmente a de Raul Brandão, pois Vida

1 É sabido que, além de romancista, Raul Brandão era dramaturgo, apesar de suas peças não terem recebido a mesma atenção dada aos seus romances. Talvez ele não tenha escolhido o teatro para tratar da trajetória do general Gomes Freire pelo fato de seu contemporâneo Teófilo Braga ter dado expressão literária ao referido episódio no seu drama histórico Gomes Freire. Vida e morte de Gomes Freire teve três edições publicadas em vida do autor, tendo sido alterado o título da primeira edição, A Conspiração de 1817 (1814), para 1817: a Conspiração de Gomes Freire na segunda edição, de 1917. A terceira edição, de 1922, manteve o título da segunda. A quarta edição apresenta uma nota explicativa: "Num exemplar de trabalho da $3^{\mathrm{a}}$ edição, Brandão introduziu inúmeras correções e alguns acrescentos com vista a uma $4^{a}$ edição, na qual o título deveria passar a Vida e morte de Gomes Freire" (Brandão, 1990, p.13). Devido à campanha antiliberal da ditadura salazarista, essa quarta edição de Vida e morte de Gomes Freire, revista pelo próprio autor (falecido em 1930), foi publicada somente em 1987, com reimpressão em 1990. 
e morte de Gomes Freire é a base histórica para a criação de Felizmente há luar!, ainda que em nenhum momento Sttau Monteiro cite suas fontes. Simões (2004) define essa obra de Raul Brandão como "um trabalho de investigação e um esboço de dramatização”.

Para o historiadorVictor de Sá, no seu prefácio para Vida e morte de Gomes Freire, esta obra de Raul Brandão, escrita logo depois de proclamada a República em Portugal (1910), insere-se na "fase de propensão historicista e de registro histórico” (Brandão, 1990, p.6) do autor. Com efeito, Vidae morte de Gomes Freire apresenta a transcrição de documentos da época, de material de arquivo (por exemplo, do Arquivo do Ministério da Guerra: Pasta Especial), de notícias de jornal, de cartas inteiras (algumas inéditas até a publicação do livro) redigidas pelos atores dos acontecimentos (por exemplo, carta de Gomes Freire ao seu amigo Sousa Falcão e vice-versa; carta do marechal governador de Elvas, João Lobo Brandão, a Beresford); afora a profusão de notas de rodapé e a bibliografia comentada ao final do volume. Todas essas referências, citadas ou transcritas por Raul Brandão, conferem legitimidade à narração do episódio histórico - daí o valor documental da obra.

O conteúdo do "repositório documental" apresentado em Vida e morte de Gomes Freire foi transformado, na peça Felizmente há luar!, em diálogos concisos, dinâmicos, resultando em embates de grande dramaticidade, favorecidos pela construção da trama e pela extremamente elaborada caracterização das personagens, com grande capacidade de argumentação e explanação de suas ideias e pensamentos. Por vezes, informações documentadas em notas de rodapé em Vida e morte de Gomes Freire passam a ser os conteúdos de falas em Felizmente há luar!:

Forjaz ao I. G. Pol. ${ }^{\text {a }} 2^{\text {a }}$ feira, 26 de maio, às 7 da tarde. [Toda do punho de Forjaz] - Comunica a Beresford o ofício do 
Intendente de 26 e as cartas inclusas do Principal Sousa (não estão) e remete resposta a Beresford "estou absolutamente pelo que diz o marechal quanto ao pouco receio que deve haver acerca da segurança dos presos, mas enfim separem-se os que parecer conveniente como estava já determinado $\mathrm{eV}$. $\mathrm{S}^{\mathrm{a}}$ julgou necessário. Quanto porem à opinião do Sr. Principal de os mandar sair na Fragata com esta precipitação parece-me mui impolítico e inconveniente; he dar a tudo hum ar de violência e injustiça que servirá às mil maravilhas os projectos dos seus adherentes - quando ainda mal temos na mão as provas da existência de uma infame conjuração que convêm aclarar e punir para fazer ceçar a continuação desta gangrena [...] Esta decisão he muito melindrosa para que se tome com ligeireza" (Torre do Tombo: Pasta Especial). (idem, p.149-50)²

\section{Em Felizmente há luar!:}

\section{PRINCIPAL SOUSA}

Não seria preferível meter todos os conspiradores numa fragata, e mandá-los... [...]

\section{MIGUEL (Depois de um momento de espanto.)}

Aqui tem, Reverência, a resposta à sua pergunta. Não! Não e não! Meter gente numa fragata seria dar a tudo um ar de violência e de injustiça que só serviria os projectos dos seus aderentes. É preciso acabar de vez com esta gangrena. Já pensou em alguém, Reverência, que a Deus e ao Estado convenha liquidar? (Sttau Monteiro, 1980, p.73)

Há clara convergência entre as duas obras - a de Raul Brandão e a de Sttau Monteiro - quanto à interpretação

2 O editor de Vida e morte de Gomes Freire explica que "A ortografia do texto de Brandão foi actualizada, a dos documentos transcritos conservada. Os nomes próprios, por exemplo, estão pois em grafia actual no corpo do texto, mas aparecem na grafia da época quando constantes em documento citado." (Brandão, 1990, p.14). Nas citações, obedecemos a essa mesma norma. 
dos fatos que implicaram a morte de Gomes Freire e de outros ditos conjurados. Em síntese, ambas denunciam a ação autoritária e extrema praticada pelos governantes contra os contestadores:

Que distância de Raul Brandão a Luís de Sttau Monteiro! E, no entanto, os dois, por igual, compreenderam e sentiram a tragédia de S. Julião da Barra nas suas escuras maquinações, nos seus tremendos subterfúgios, nas suas impiedosas "razões de Estado" alimentadas pela cega obstinação dos que mais depressa renegam a justiça em nome de Deus do que Deus em nome da justiça. (Simões, 2004, p.141)

Os motivos da prisão e execução do general podem ser resumidos em duas falas de Felizmente há luar! proferidas por dois dos governadores do reino à Matilde. Quando esta suplica ao marechal inglês que o liberte porque o general não cometeu crime algum, Beresford lhe responde: "A simples existência de certos homens é já um crime” (Sttau Monteiro, 1980, p.108). E o Principal Sousa, ao ser acusado por ela de ter mandado prender e condenar um inocente, "em tom moderador" diz "As razões do Estado..." (idem, p.141). Nesse sentido, concordamos com o comentário de António Quadros (1964, p.241-2) sobre Felizmente há luar!:

É o antiquíssimo tema de Sófocles na Antígona patenteando a contradição, para os gregos irresolúveis, entre as leis explícitas do Estado e as leis implícitas de Deus ou da Razão ou de um princípio transcendente ao poder e ao mundo. A actualização histórica, social e filosófica de Luís de Sttau Monteiro alarga, porém, o prisma grego de visão [...] é o que partindo do gênero antagônico de cisão entre lei implícita e lei explícita, sublinha a angustiosa cisão entre os investidos do poder e o povo.

Gomes Freire não aparece efetivamente em cena, e, na lista de personagens de Felizmente há luar!, lemos a se- 
guinte indicação: “O GENERAL GOMES FREIRE D' ANDRADE - que está sempre presente, embora nunca apareça" (Sttau Monteiro, 1980, p.12), o que nos remete a uma semelhante definição em duas obras anteriormente publicadas. Em Vida e morte de Gomes Freire temos: "Gomes Freireé um inimigo que, mesmo calado, os incomoda." (Brandão, 1990, p.223). E no drama histórico Gomes Freire - cujo protagonista dá título à obra de Teófilo Braga-lemos a fala de uma personagem (José Pedro Marques, professor do Colégio Militar) que denuncia três nomes de inimigos de Beresford: “... e sempre essa figura, que não apparece, e se sente em toda a parte, Gomes Freire (...)” (Braga, 1907, p.37). ${ }^{3}$ Sttau Monteiro refere-se ao drama histórico de Teófilo Braga e à obra documental de Raul Brandão de forma indireta, sem citar essas fontes.

Essa "presença" sem aparição de Gomes Freire, ou essa presença que "não aparece", mas da qual se sabe, suprime a ênfase que se poderia dar à personagem como tal. Não sendo ela figura física, transforma-se em figura simbólica. A cena última de Matilde "a abraçar um ser imaginário", indica-nos a rubrica, a fazer o gesto de abotoar-lhe o casaco, tendo ao longe e ao fundo o clarão da fogueira, reconstrói uma imagem ou uma memória da figura de Gomes Freire, cuja presença e tudo o que ela pode significar é já tão clara: "Julguei que isto era o fim e afinal é o princípio. Aquela fogueira, António, há-de incendiar esta terra!” (Sttau Monteiro, 1980, p.164), diz Matilde. Assim, os motivos que levaram à morte de Gomes Freire sobressaem-se, ultrapassando sua figura física para torná-la símbolo de resistência, de contestação - e também de esperança, vivificando, por isso, sua presença.

3 Em todas as citações desta obra de Teófilo Braga, respeitaremos a ortografia da edição de 1907. 


\section{Papéis e gestos}

Ao abrirmos o livro que traz a peça Felizmente há luar!, deparamo-nos com uma divisão de todas as páginas em duas partes: a da direita, que traz os diálogos permeados de rubricas, como acontece usualmente em textos dramáticos; e a da esquerda, que apresenta rubricas apartadas do texto da fábula - às quais chamaremos de indicações paralelas. Mário Vilaça (1962, p.137), para quem as notas à margem do texto da peça deSttau Monteiro são “profusas e por vezes repetidas”, sugere que elas sejam ignoradas na encenação. Essas indicações paralelas podem, no entanto, representar uma preocupação com a forma ou estética empregada na encenação; elas constituem, portanto, não apenas orientações do dramaturgo ao diretor, mas refletem o momento político da época da criação da peça, como aponta Barata (1991, p.379):

Mais do que elementos para uma possível encenação (e na altura em que foi escrita representar Felizmente há luar! não passava de uma remota hipótese!) talvez o autor pensasse essencialmente numa "leitura orientada", sabendo que a peça dificilmente ultrapassaria o domínio do literário.

Sem descartar nenhuma das explicações da razão dessas rubricas do canto esquerdo da página, ou "notas à margem do texto", ou ainda orientações para a leitura, achamos que elas são importantes, pois nos indicam o tipo de gesto a ser assumido pelo ator; apresentam comentários do autor a respeito da situação referida e revelam a preocupação do dramaturgo em tornar clara a pretensão das cenas:

A pergunta é acompanhada dum gesto que revela a impotência da personagem perante o problema em causa. Este gesto é francamente "representado". O público tem de entender, logo de entrada, que tudo o que se vai passar no palco tem um significado preciso. (Sttau Monteiro, 1980, p.14) 
No início do segundo ato, Manuel, alterando o tom de voz, "sai" da personagem que narra - mudando totalmente o caráter da cena - para assumir, de forma alternada, outras duas personagens:

Manuel representa agora, e quase simultaneamente, dois papéis. Quando passa dum para o outro, os seus gestos devem ser rápidos e enérgicos para que o público compreenda o que se está passando.
Fala com ironia, mas a frase deve ser proferida de forma a compreender-se que ainda a dirige à personagem que se afasta.

Agora fala sozinho, e o seu tom de voz é, portanto, o habitual.
Uma esmola por alma de quem lá tem, meu senhor...

Também sou homem, também tenho fome, filhos que queriam ver homens, olhos para ver o luar, voz para dizer o que sinto, costas que morro a vergar... Uma esmola por alma de quem lá tem, senhor... (Estende a mão. Num gesto brusco toma a posição do indivíduo a quem estava a falar. Assume uma atitude nobre. Torna-se duro e ríspido). Tome lá cinco réis, homenzinho, e cale-se. Não me toque! Estenda a mão... vá! E deixe-se de lamúrias! Não preciso que me ensine os meus deveres de cristão; eu amo o próximo como a mim mesmo. (Faz o gesto de quem deixa cair uma moeda na mão dum pobre). Afaste-se! Deixe-me passar. (Dum salto volta à sua posição inicial, estende a mão $e$ adopta, novamente, o tom de voz anterior) Muito obrigado, meu senhor! (Faz uma vênia) Muito obrigado, meu senhor, pelo favor de me amardes como a vós mesmo. (Finge examinar a moeda imaginária que acaba de receber).

No Dia de Juízo, Deus Nosso Senhor levar-nos-á em conta estes cinco réis...

(Faz uma nova vênia e fica todo inclinado com os olhos na personagem imaginária que se afasta. Por fim, endireita-se e fica parado, no palco, em atitude de meditação.)

Esta madrugada prenderam Gomes Freire... Levaram-no escoltado para S. Julião da Barra. Já de lá não sai vivo! (Para o palco) Que mais sabem vocês da prisão do general? (Ilumina-se o fundo do palco, que se encontra repleto de gente do povo disposta exactamente como para a cena de abertura do primeiro acto).

(idem, p. 86-8) 
O diálogo estabelecido entre essas duas personagens representadas por Manuel mostra que o dever cristão de amar ao próximo como a si mesmo - se reduz a uma moeda de cinco réis, ironizando a máxima cristã. Dando a moeda ao pobre, o nobre sente ter cumprido seu dever e ter se livrado de "lamúrias". Essa pequena peça dentro da peça (protagonizada pelo mesmo ator que representa duas personagens) interrompe uma narração para introduzir outra. Assim, desfaz-se a continuidade cênica, de forma a salientar o caráter episódico da peça, nos moldes do teatro épico brechtiano.

A moeda de cinco réis torna-se então simbólica. Quando Matilde se dirige aos populares - "Você aí, sabe quem eu sou? Tenho lhe dado esmolas vezes sem conta" -, ninguém parece ouvi-la, até que Manuel lhe dirige a palavra:

Todos, aqui, sabemos quem a senhora é, e nenhum de nós é cego ou surdo [...]. Perguntou-nos, há pouco, o que íamos fazer para libertar o general... Insinuou mesmo que éramos responsáveis pela sua prisão, já que tínhamos fé nele... Olhe para nós, Sra. D. Matilde. Abra bem os olhos e veja quem somos e ao que estamos reduzidos [...] Mas nós passamos a vida inteira a ir ter convosco porque também não temos a quem recorrer! E que nos dão, senhores, que nos dão quando lhes batemos às portas no Inverno, com os filhos embrulhados em trapos, tão cheios duma fome que o pão, só por si, não satisfaz? (Pausa) Cinco réis, senhores! Dão-nos cinco réis ou dizem-nos que tenhamos paciência. (idem, p. 120-2)

No meio da fala, Manuel parece voltar-se para o público e para o "povo" do palco: "E o que nos dão, senhores?" Matilde pede a moeda - também ela, como todos ali, não sabe o que fazer. Manuel dá-lhe a moeda, mas não como esmola, e sim como uma medalha, para que a use no peito. Com esse gesto, é Matilde a assumir simbolicamente a função que seria de Gomes Freire, qual seja, a de não per- 
der as esperanças e continuar lutando, por isso a luz que iluminava o povo apaga-se e apenas a mulher permanece iluminada no palco.

Tanto nas indicações paralelas como nas rubricas entre os diálogos há orientações frequentes sobre os gestos dos atores, que muitas vezes sugerem oposição à dramaticidade das palavras, configurando, assim, uma proposta de linguagem corporal, bem próxima do gestus brechtiano, permitindo ao espectador compreender o sentido mais profundo da cena.

A linguagem gestual no teatro épico de Brecht define-se pela unidade que se constitui entre gesto e palavra; pode ocorrer, todavia, o caso em que o gesto é superior à palavra (Bolle, 1986). A personagem Matilde, por exemplo, vivifica na cena a imagem de Gomes Freire, representada pelo uniforme que ela acaricia e abraça; tal gesto é muito mais significativo que suas palavras, por simbolizar a personagem ausente. Quando a personagem Vicente, no primeiro ato, está a falar com os dois policiais sobre sua origem, seus gestos são detalhadamente descritos nas indicações paralelas. São todos gestos estudados, de pessoas da classe a que Vicente gostaria de ter pertencido: "Ao falar, faz gestos com as mãos, gestos lentos, precisos, copiados dum fidalgo qualquer que teve a ocasião de observar de perto" (Sttau Monteiro, 1980, p.28). São os gestos que, na encenação, contribuem para a caracterização dessa personagem. Como desdenha de sua própria origem, Vicente, nas cenas seguintes, irá se unir aos governadores do reino, inimigos de Gomes Freire, a fim de atingir o objetivo de ascender socialmente: "Cheira-me a coisa graúda... [a conversa marcada com D. Miguel Forjaz] Se eu souber fazer render o peixe, sou capaz de acabar com uma capela... ou chefe de polícia, quem sabe?" (idem, p.31) - e é o que ele consegue.

Na encenação épica, segundo Bolle (1986), a compreensão do discurso fica efetivamente clara se o sentido básico for 
expresso antecipadamente pelo gestus. É o que ocorre na cena em que Miguel Forjaz suborna Vicente: "Se cumprir essa missão com zelo que lhe impõe o seu dever [...] prometo-lhe que não acabará os seus dias a pedir. Interessa-lhe a chefia de um posto de polícia?” (Sttau Monteiro, 1980, p.40). O Principal Sousa "Estende o braço num gesto que, não sendo o da bênção, deve, todavia, sugeri-lo" (ibidem, grifo nosso), e diz a Vicente: "Vá, meu filho, e ajude-nos a cuidar do rebanho, indicando-nos as ovelhas tresmalhadas antes que elas contagiem as restantes. Que Deus o proteja na sua missão" (idem, p.40-1). Não sendo o da bênção, seu gesto abençoa tanto o suborno quanto a traição.

O trabalho gestual mais complexo aparece na cena em que ao se referir a Gomes Freire, o Antigo Soldado diz: "Quem fez aquele não fez outro igual...", momento em que Manuel inicia a frase, mas não a termina: "Se ele quisesse...”. Há um silêncio, acompanhado de um gesto das personagens que, diz a rubrica, "olham para as mãos e para os lados. Foram longe demais e sabem-no" (idem, p.20). O gesto de olhar para as mãos e para os lados, considerando o silêncio, destoa do entusiasmo e até da descontração com que essas personagens vinham conversando sobre Gomes Freire; é como se o gesto e o silêncio preparassem a entrada eminente de Vicente a contestar a importância dada a Gomes Freire por aqueles populares todos. A interrupção da frase, seguida do silêncio e dos gestos das personagens, rompe com a linearidade da cena, produzindo o distanciamento.

Tão precisa nas indicações paralelas, a descrição dos gestos nos permite fazer pelo menos duas suposições, apoiados nos comentários já tecidos por alguns críticos: a de que, de fato, Felizmente há luar! traz no texto uma clara orientação de leitura, ou a de que as indicações paralelas são direcionadas, na verdade, ao encenador. A única certeza é a de que uma suposição não exclui a outra. 


\section{Frase-título: histórica e distanciada}

Já transcrita por Teófilo Braga e Raul Brandão, a frasetítulo "Felizmente há luar" tornou-se de fato famosa com a peça de Sttau Monteiro. Ela dá o título ao décimo e último capítulo do livro de Raul Brandão, e aparece no epílogo do drama histórico de Teófilo Braga na fala da Dama (na verdade, D. Maria do Patrocínio, personagem que, no prólogo, dialoga com a viscondessa de Juromenha e depois com Gomes Freire):

A mão que eu beijava com piedade filial, a mão de meu tio, na hora tremenda das execuções bárbaras do Campo de Sant'Anna, escreveu esta execranda phrase: "É verdade que a execução se prolongará pela noite, mas felizmente há luar, $e$ parece-me tudo tão socegado, que espero não cause isto prejuizo algum..." Acabaram as execuções por um incendio pavoroso, mas prolonga-se a noite moral, em que parece tudo socegado, porque está em colapso de lethargia a consciencia do povo. (Braga, 1907, p.270, grifo do autor)

Sttau Monteiro não cita a fonte do título, tampouco a da matéria histórica que aproveita para a criação de sua peça: "é que a história ali [em Felizmente há luar!] não a documentam arquivos, não a comprovam testemunhos documentais" (Simões, 2004, p.140). Recorrendo aos documentos fornecidos por Raul Brandão e pelos historiadores, vamos confirmar que a frase "Felizmente há luar" saiu da pena de uma personalidade histórica, D. Miguel Pereira Forjaz (o "tio” da personagem na citação acima), um dos governadores do reino, em carta ao intendente geral da polícia na tarde da execução de Gomes Freire, em 18 de outubro de 1817:

[...] he verdade que a execução se prolongará pela noite, mas felizmente ha luar e parece-me tudo tão socegado que espero não cause isso prejuizo algum. Será bom que V. Sa me com- 
munique o que se passar. (Torre do Tombo: Arquivo da I. G. da P.). (Brandão, 1990, p.250, nota 3)

Além de usá-la como título da peça, Sttau Monteiro a incorpora à fala da personagem D. Miguel Forjaz em diálogo com o Principal Sousa, nas cenas finais do segundo ato, no momento em que eles comentam a execução dos conjurados condenados à forca e depois à fogueira:

\section{MIGUEL}

Lisboa há-de cheirar toda a noite a carne assada, Excelência, e o cheiro há-de-lhes ficar na memória durante muitos anos... Sempre que pensarem em discutir as nossas ordens, lembrar-se-ão do cheiro... (Com raiva) É verdade que a execução se prolongará pela noite, mas felizmente há luar... (Sttau Monteiro, 1980, p.153)

D. Miguel Forjaz é quem primeiro acusa Gomes Freire de conspiração, para, no segundo ato, negar-se a receber Matilde de Melo que vai lhe pedir auxílio em favor do companheiro. O tom da fala de D. Miguel, antes da raiva, é o da ameaça que reflete o seu abuso de autoridade. Ele quer "ensinar" por meio do exemplo-a execução de Gomes Freire - que conjuga a repressão e a força.

A mesma frase é repetida, em um "quase grito", por Matilde na última fala da peça, alterando, obviamente, o sentido das palavras:

\section{MATILDE \\ $[\ldots]$ \\ (Para o povo)}

Olhem bem! Limpem os olhos no clarão daquela fogueira e abram as almas ao que ela nos ensina! Até a noite foi feita para que a vísseis até o fim...

(Pausa)

Felizmente-felizmente - há luar! 
(Desaparece o clarão da fogueira. Ouve-se ao longe uma fanfarra que vai num crescendo de intensidade até cair o pano) (idem, p.164)

Matilde também quer ensinar, ela também toma o acontecimento narrado como exemplo, mas com o intuito contrário ao de Forjaz. Para Matilde, não é o cheiro que a memória guardará, mas a visão tornada possível pelo clarão da fogueira e pelo luar, metáfora da luz capaz de abrir as mentes para a análise crítica da realidade.

Marcando a contraposição entre esses dois tipos de "ensino", a frase "Felizmente há luar" é deslocada de uma personagem (D. Miguel Forjaz) para outra (Matilde de Melo), de um posicionamento ideológico (manutenção do Poder pela força e pela opressão) para outro (contestação do Poder pela crítica). E isso em um mesmo contexto políticosocial, o das aspirações liberais na primeira metade do século XIX, que deve espelhar a situação política de Portugal na década de 1960. Tal deslocamento modifica o significado da frase e amplia sua projeção. Na boca de Matilde, a frase traduz a esperança, porque ver a cruel execução significa ter a clara percepção da injustiça praticada contra aqueles que se opõem ao poder instituído, e isso não poderá jamais se repetir. Dita por ela, ao mesmo tempo em que ganha novo sentido, a frase provoca o distanciamento no espectador. Mesmo que o público desconheça o caráter histórico da frase, o efeito de distanciamento é provocado por seu deslocamento de uma para outra personagem. Oliveira Barata (1991, p. 378, grifo do autor) relaciona essa repetição da frase-título à divisão em dois atos da peça, em que o primeiro ato mostra o "funcionamento do poder" e o segundo, o "domínio do antipoder", de modo que

Felizmente há luar! Duplamente repetido. Anteriormente, cinicamente "anunciado por D. Miguel [...]. A duplici- 
dade de intenções desta elocução e o contexto situacional em que é proferida, serve assim, mais uma vez, a estrutura dual que se preocupa apresentar: a frase dita pelo Poder e dita pelo antipoder.

D. Miguel Forjaz é o representante do Poder no primeiro ato, e Matilde a do antipoder no segundo; muda a personagem e com ela o sentido atribuído à repetição da frase.

Em uma outra perspectiva de análise, vemos que a frase como título faz dupla referência: à redação do episódio histórico documentado por Raul Brandão e à ficcionalização da história por Teófilo Braga; dialoga, pois, com a história e com a literatura. A partir dos textos que registram o episódio, Sttau Monteiro relê e "reescreve" a história, mostrando de forma metafórica a possibilidade de transformação do processo histórico. É o que mostra Matilde ao repetir a frase de D. Miguel Forjaz, com a qual termina a peça. Assim, a peça assimila os pressupostos do teatro épico não apenas no que se refere aos aspectos técnicos formais, mas principalmente no tocante ao pensamento de Brecht e a sua intenção de desenvolver esse tipo de teatro. Em um de seus registros, o dramaturgo alemão afirmou que

o teatro épico interessa-se pelo comportamento dos homens uns para com os outros, sobretudo quando é um comportamento (típico) de significação histórico-social. Dá relevo a todas as cenas em que os homens se comportam de tal forma que as leis sociais a que estão sujeitos surjam em toda a sua evidência. E, ao fazê-lo, cabe-lhe descobrir definições praxísticas dos acontecimentos em processo, istoé, definições que, ao serem utilizadas, possibilitem uma intervenção nesses mesmos acontecimentos. [...] O comportamento humano é apresentado, no teatro épico, como sendo suscetível de transformação e, o homem, como dependente de determinadas condições econômico-políticas, condições que são, simultaneamente, capazes de modificar. (Brecht, 2005, p.228) 
Ao deslocar a frase para a última fala de Matilde, Sttau Monteiro, para além da estranheza provocada, confere ao espectador, na esteira de Brecht (ibidem), a "oportunidade para uma crítica do comportamento humano segundo uma perspectiva social e a cena é representada como cena histórica". Nessa relação do homem com a história, aquilo que lhe parecia conhecido se revela estranho, conforme a releitura da história proposta pela peça. Para Oliveira Barata (1991, p.379, grifo do autor):

A emergência da história no discurso dramático, privilegiando-se e remotivando-se um núcleo 'mítico' - ao qual o espectador não deveria aderir empaticamente -, satisfazia um duplo objectivo: servir de exemplo, para a reflexão, e, simultaneamente contribuir para a transformação da realidade contestada.

A reflexão produzida por Felizmente há luar!, frase e peça, está centrada metaforicamente na possibilidade de mudança, poisohomem "Nãoésó vítima da história; étambém propulsor dela” (Rosenfeld, 2006, p.172).Eéessa ideia-dequeohomem deve ter consciência de que depende da situação histórica, a qual, por sua vez, pode ser por ele transformada-quejustifica a desaprovação da peça pela comissão de censura de Salazar.

O fato histórico, tornado cênico, não pretende ser apenas representativo do passado, nem tampouco mostrar uma verdade histórica; longe dessas preocupações, a peça de Sttau Monteiro trabalha a inserção de textos da história, esperando do seu espectador/leitor não o reconhecimento do passado histórico, mas uma análise profunda desse passado como reflexão sobre o momento presente.

\section{Dimensão épico-brechtiana}

Sttau Monteiro faz uso de recursos narrativos, de gestos precisamente definidos nas indicações e de um cenário 
esvaziado de objetos cênicos, como ele próprio resume em uma das primeiras indicações paralelas: "os gestos, as palavras e o cenário são apenas elementos duma linguagem a que [o público] tem de adaptar-se" (Sttau Monteiro, 1980, p.13). É clara a preocupação do dramaturgo em avisar que estamos diante de outra linguagem, outra forma ou, ainda, outra estética dramática.

O fato de os dois atos começarem propositadamente da mesma forma, com a mesma frase - "Que posso eu fazer?" -, chama a atenção do leitor/espectador para a análise e comparação entre o que se narrou no primeiro ato e o que se começa a narrar no segundo. A repetição - da mesma pergunta pela mesma personagem, Manuel, e do mesmo enquadramento cênico: "os atores devem ocupar no início deste acto as mesmas posições que ocuparam no primeiro" - representa, no segundo ato, a falta de perspectiva dos populares perante a vigência impositiva do Poder: "E ficamos piores do que estávamos... Se tínhamos fome e esperança, ficamos só com fome... Se durante uns tempos acreditávamos em nós próprios, voltamos a não acreditar em nada" (idem, p.86). A prisão de Gomes Freire parece assinalar a perda da pouca esperança que havia, de par com o sentimento de que não há mais forças para resistir:

\section{SOUSA FALCÃO (Com ternura)}

Todos somos chamados pelo menos uma vez a desempenhar um papel que nos supera. É nesse momento que justificamos o resto da vida, perdida no desempenho de pequenos papéis indignos do que somos. (idem, p.100)

Matilde, personagem que vai se transformando no decorrer da peça, é quem irá restituir algum alento, na esperança de que a morte de Gomes Freire ensine algo aos homens.

O processo narrativo que confere dimensão épico-brechtiana à peça é ativado principalmente pelas funções de 
comentador - que assume a voz coletiva - e de narrador dos fatos, atribuídas a Manuel, "o mais consciente dos populares”, e pelos monólogos de Matilde.

O extenso monólogo de Matilde tem duas partes, separadas por um diálogo com Sousa Falcão, amigo de Gomes Freire. Nas duas partes, a mesma sequência de assuntos: o filho, o marido e, por fim, a decisão de lutar pela vida de Gomes Freire. É o que ela fará nas cenas seguintes, ao procurar os governadores do reino.

Quando Matilde entra em cena - para não mais deixar o palco -, sua fala "sozinha" tem, inicialmente, a mesma função dos recursos épicos brechtianos, qual seja, a de interromper a ação:

Ensina-se-lhes que sejam valentes, para um dia virem a ser julgados por covardes!

Ensina-se-lhes que sejam justos, para viverem num mundo em que reina a injustiça!

Ensina-se-lhes que sejam leais, para que a lealdade, um dia, os leve à forca!

(Levanta-se)

Não seria mais humano, mais honesto, ensiná-los, de pequeninos, a viverem em paz com a hipocrisia do mundo?

(Pausa)

Quem é mais feliz: o que luta por uma vida digna e acaba na forca, ou o que vive em paz com a sua inconsciência e acaba respeitado por todos?

(idem, p.92-3)

O contraste entre o tom poético desta fala e a cena imediatamente anterior ao surgimento de Matilde (enquanto os policiais desfazem o ajuntamento, Rita narra a reação de Matilde ante a prisão do companheiro) quebra a dinâmica da encenação, tornando-a estática. A mudança de ritmo, aliada ao uso de antíteses e anáforas na fala de Matilde, provoca o efeito de distanciamento. 
Para Fernando Mendonça (1971, p.102) “Luís de Sttau Monteiro estabeleceu o modelo que nos oferece uma linguagem dramática [composta por diálogos] coordenada numa sintaxe épica [narrativa]". Mas nem sempre a linguagem é específica ou totalmente dramática. É o caso do monólogo de Matilde, que se estende por todo o segundo ato.

Sabe-se que o monólogo foi uma forma firmemente recusada pelo teatro naturalista devido à sua inverossimilhança - ninguém fala tanto tempo sozinho em voz alta -e por representar uma paralisação da ação, função rejeitada por esse tipo de teatro que preza justamente a linearidade da ação. Para o teatro épico, ele traz uma vantagem, a de interromper a ação, revelando a teatralização, mas também uma desvantagem porque pode configurar-se em um discurso que a personagem faz para si mesma, em uma "linguagem interior" entre o "eu locutor" e o "eu ouvinte" (Pavis, 2007). Segundo Bornheim (1992, p.324), Brecht resolve bem a questão, lançando o monólogo para o épico, ou seja, utiliza-o como uma técnica - afinal, "canções e comentários são quase monólogos" e servem para distanciar a ação; por isso, "talvez caiba dizer que o que cai por terra [no teatro épico] não é propriamente o monólogo tradicional, e sim a quarta parede, o palco já não se fecha mais contra o público”.

Voltando ao monólogo de Matilde, verificamos que ele, em sua extensão, apresenta ainda outras características, além da função de interromper a ação:

Um dia, encontramos o nosso homem a sonhar um outro mundo - sabemos que esse sonho põe termo à paz que tanto desejamos, e, mesmo assim, queremos dizer-lhe que siga o seu caminho, que iremos com ele até ao fim, mas não sabemos por onde começar... (Sttau Monteiro, 1980, p.102)

A primeira pessoa do plural estabelece uma aproximação com o espectador (em especial com as mulheres: mães e 
esposas), tornando grande a probabilidade de o espectador identificar-se com essas palavras. À primeira vista, essa passagem do monólogo parece contrariar a orientação das indicações paralelas, de que "ninguém esboce um gesto para cativar ou acamaradar com o público". Cumpre ressaltar, no entanto, o sentido pedagógico do texto que se estrutura na citação de um exemplo que, acionado, funciona como contributo ao ensino. Trata-se, portanto, mais de uma estratégia pedagógica que de uma técnica de identificação. É a vida dessa mulher ao lado do homem amado que ensinou a ela uma nova forma de ver o mundo que o monólogo transmite e a peça quer ensinar.

Em Felizmente há luar! as personagens se movimentam no palco, indo de um a outro espaço subentendido pela ação ou pela presença de outras personagens, já que não há exatamente um cenário, apenas objetos como cadeiras, caixotes, uma cômoda e outros. Nas cenas em que aparecem os populares, por exemplo, dá-se a entender que eles estão em um espaço público, em uma rua ou em uma praça, mas não há indicação de serem, de fato, esses lugares. Da mesma forma que as personagens "surgem" no palco, surgem também os objetos de cena; da mesma forma que os gestos não podem sobrar ou aparecer sem função, os objetos também não; por isso há uma economia do uso de materiais cênicos. O exemplo mais claro é a cômoda que "surge" na cena em que Matilde fala sozinha, no segundo ato. Desse móvel, ela tira o uniforme de Gomes Freire, o qual acaricia com ternura enquanto fala. Nesta mesma cena, há um momento em que Matilde faz o gesto de fechar uma janela, à qual se tinha referido anteriormente: "Abríamos a janela ao sol da manhã e aquecíamo-nos os dois..." (idem, p.94); muito curioso é que não há uma indicação do gesto de abrir a janela, como se as palavras - "Abríamos a janela” - substituíssem o gesto e os dois (gesto e palavras) substituíssem o objeto cênico. As indicações no texto são 
tão precisas, que, quando lemos um comentário sobre a peça como o de Simões (2004, p.140), originalmente escrito em 1962, temos a impressão de que ele fala da encenação e não do texto da peça, à altura ainda impedida de ser representada nos palcos portugueses:

A primeira peça histórica sem barbas postiças nem castelos de papelão. Um palco aberto e alguns projectores incidindo sobre uma cena às escuras. É aí, nessa boca de cena tão despojada e tão nua como a de qualquer tragédia clássica ou de qualquer auto de Gil Vicente [...] que se desenrola a tragédia de Gomes Freire, protagonista invisível de Felizmente há luar!

Da perspectiva do teatro épico brechtiano, os objetos cenográficos não precisam estar efetivamente presentes; basta que sejam sugeridos ou que a eles se faça alusão, como faz Matilde ao fechar uma janela que não há.

Em algumas cenas, as autoridades são simbolizadas apenas pelo som dos tambores e sinos. Os sinos representam a autoridade religiosa e os tambores indicam a aproximação dos militares. Quando os sons desses sinos e tambores são ouvidos pelas personagens, elas mudam de atitude, de gestos, e a cena é imediatamente modificada, desfazendo a linearidade da sequência cênica.

A caracterização da linguagem cênica, bem como a forma como a fábula é desenvolvida, põe a peça de Sttau Monteiro em consonância com a estética teatral brechtiana. Felizmente há luar! apresenta técnicas de distanciamento sem reduzir a teoria de Brecht a uma fórmula ou esquema; talvez seja por isso que, na peça, não vemos aqueles recursos épicos mais famosos que marcaram a encenação desse tipo de teatro, como projeções de filmes, títulos nas cenas, cartazes e outros. Na verdade, o caráter épico da peça, para além da estrutura, apresenta-se em outra dimensão, muito embora se aproveitando da forma proposta por Brecht. 
A repetição da frase-título por personagens antagônicase a repetição do enquadramento cênico no início dos dois atos afinam-se no caráter dialético das relações político-sociais constituintes do processo histórico e debatidas na peça. As contradições no processo são notórias: o povo não promove nenhuma ação em favor da libertação do general; Matilde, personagem também do povo, é a primeira a cobrar uma ação dos populares: "Por quanto tempo é que o vão deixar metido numa masmorra, perdendo aos poucos a fé que tinha na gente desta terra?" (Sttau Monteiro, 1980, p.116); Gomes Freire é delatado por Corvo, Sarmento eVicente, pessoas do povo que lutam pelos seus interesses individuais, igualandose, por isso, aos governadores do reino. É a exposição/narração dessas contradições que chama a atenção do espectador e o leva à análise crítica da realidade em que ele se insere, de modo que "Se o teatro ignorasse que tudo é contradição, procurando de algum modo encobrir esse fato, representaria a falsificação da própria realidade. Assim, o que vale para o social e para o indivíduo deve valer também para o texto dramático e para as personagens" (Bornheim, 1992, p.272); por isso, os conflitos são expostos como conflitos sociais, a contradição é intrínseca a eles e precisa, pois, aparecer na peça-como, de fato, aparece. 


\title{
Considerações finaIS
}

\author{
Apesar de todos os desafios, \\ provocações e interdições, \\ nunca o teatro deixará de ser \\ a imagem da vida em profundidade \\ em movimento, nunca se cansará \\ de encorajar os homens a dizer \\ que não a tudo o que os mutila, \\ os rebaixa, os diminui, os desfigura, \\ os oprime, e a roubar o fogo \\ àqueles que abusivamente o retêm \\ nas suas mãos. Para distribuí-lo \\ por todos. \\ (Rebello, 1972, p.253, \\ grifo do autor)
}

Se logo depois da Segunda Guerra, e mais especificamente na década de 1960, o teatro português passa a ter outra configuração mais ou menos em conformidade com as novas estéticas teatrais que já se praticavam mundo afora, um dado que contribui para essa movimentação na cena teatral é a existência inegável de uma crescente oposição ao regime de Salazar. Paulatinamente as rédeas do poder iam sofrendo abalos aqui e ali. 
O período em que as peças de Cardoso Pires e de Sttau Monteiro foram publicadas é marcado pelo crescimento dos movimentos oposicionistas ao salazarismo. É a fase da “agitação", como bem definiu Oliveira Marques (1998). Já aqui mencionamos a crise política de 1958, com as eleições para presidente, quando Humberto Delgado, concorrendo ao cargo, atraiu o interesse de um grandioso número de portugueses preocupados com a situação política do país. Em 1961, Delgado e Henrique Galvão chefiavam a captura do paquete Santa Maria por exilados políticos. Ainda em 1961, uma tentativa (fracassada) de golpe de Estado contra Salazar era liderada pelo Ministro da Defesa, Botelho Moniz; o exército indiano invadia as possessões portuguesas na Índia - Goa, Damão e Diu; e nas colônias africanas começavam as guerrilhas pela independência. Em 1962, uma rebelião militar era imediatamente reprimida em Beja, enquanto protestos do movimento estudantil e de outros segmentos da sociedade eclodiam em greves e manifestações. Mas Salazar continuava no Poder...

Já desde 1946, com o microteatro do grupo TeatroEstúdio do Salitre, de Luiz Francisco Rebello, Gino Saviotti eVasco Mendonça Alves e suas novas ideias de dramaturgia e encenação antinaturalistas, os artistas de teatro propunham um olhar crítico para a realidade, influenciando grupos que nasciam e conquistando a adesão de outros que se voltavam para os mesmos propósitos. Claro, o teatro batia de frente com as ideias salazaristas.

Salazar era contrário às mudanças, valorizava a tradição, queria que os cidadãos lusos ficassem "orgulhosamente sós" no seu "Mundo Português", criado ficticiamente para a contemplação e exaltação do passado histórico, a fim de "confirmar" que no presente se vivia bem. O ditador procurava fazer crer que a história é uma "evolução sem sobressaltos" (Santos, 2004) e que, por isso, os portugueses deveriam viver normalmente, como de costume, comemorar 
e celebrar o passado histórico que os ajudara a chegar aonde chegaram! A Exposição do Mundo Português em $1940^{1}$ foi o "grande show" do regime, como declarou o comissário-geral da exposição, Augusto Castro (idem). Era o ano dos centenários e comemorações (1140: fundação de Portugal; 1640: restauração da dinastia nacional e coroação de D. João IV); e 1940 era, nas palavras de António Ferro: ${ }^{2}$ o "ano apoteótico do ressurgimento". Viria daí a ideia de apoteose grotesca e trágica de Cardoso Pires e de Sttau Monteiro?

Esses dois autores, como vimos, tomaram fatos históricos de Portugal para a construção de suas fábulas. Nesse sentido, não sem ironia se punham de acordo com os preceitos do regime, que enaltecia a história do país. Era o que a gente toda, isto é, o público, conhecia. Então, nada mais natural. Cardoso Pires vai ainda mais longe ao escolher um episódio ocorrido justamente na zona rural para construir a sua fábula. Ora, era o que Salazar aprovava, pois ele, o ditador, valorizava a vida aldeã:

Esta afirmação da superioridade da vida no campo sobre a vida urbana articula-se com a noção de humildade pregada pelo regime e que fazia parte do retrato psicológico dos

1 Inaugurada solenemente em Lisboa, em 23 de junho de 1940 (encerrada em dezembro do mesmo ano), a exposição aconteceu em três conjuntos de edifícios, um consagrado à História, outro à Etnografia Metropolitana e o terceiro à Etnografia Colonial. Tinha como objetivo apresentar o estilo português de 1940. Muitos artistas foram chamados para "criar" esse estilo; a intenção, na verdade, era a de inventar uma identidade nacional que seria então celebrada durante todo o regime. Os historiadores informam que a exposição recebeu perto de três milhões de visitantes.

2 Segundo Graça dos Santos (2004, p.67), para Antonio Ferro - chefe responsável do Secretariado de Propaganda Nacional (SPN) do regime e secretário-geral da Exposição -, 1140, 1640 e 1940 eram os anos sagrados para a história de Portugal, sendo respectivamente “ano do crescimento", "ano do renascimento" e, como já citamos, “ano apoteótico do ressurgimento”. 
portugueses idealizado pelo chefe do Estado Novo. Donde a placidez patriarcal e rústica do campo, em oposição à agitação e convulsão citadinas, o que é também uma forma de incitar os camponeses a permanecerem no campo.

(idem, p.68-9)

Para Cardoso Pires, o teatro é uma leitura e sua leitura da revolta popular da Maria da Fonte é uma forma de manifestação artística contra o regime. Na peça, não existe ingenuidade das pessoas do campo; há, sim, uma impotência diante do Poder, e por isso há gente fingindo-se de cega para sobreviver. Se pensarmos que Vilar - a aldeia apresentada em O render dos heróis - é a representação "microcósmica" de Portugal da segunda metade do século XX, podemos tirar daí pelo menos duas assertivas. Uma, que Cardoso Pires mostra uma vida aldeã com homens que têm plena consciência da situação de opressão em que se encontram, uma vez que a peça começa, vale lembrar, pela narração dos motins iniciais da revolta popular, contrariando, pois, a vontade do regime, que quer fazer acreditar que a vida no campo é desprovida de mudança ou agitação e, por isso, é a representação da tradição. Outra que, mesmo tendo sido reprimida, houve uma tentativa de revolta que, sem a dependência de um herói, fez, ainda assim, valer, se não a transformação desejada, pelo menos o despertar da consciência para a realidade.

Não há na expressão que constitui o título $O$ render dos heróis pessimismo ou negatividade, mas o claro convite à reflexão. Se a história era, para o regime, a exaltação de heróis e de feitos históricos, na peça de Cardoso Pires a fábula mostra que a história não precisa de heróis - pelo menos a história que agora se constrói. A peça revela que a história é um processo e, como tal, é dinâmica, no sentido de que está sempre em transformação e, mais, de que não existe evolução sem sobressaltos. O fato de Maria Angelina ser, na 
peça, a Maria da Fonte não tem importância alguma. Teria se estivesse o autor preocupado em construir sobre a figura, líder da revolta popular, uma imagem de herói; mas não. A dúvida que perpassa as falas de algumas personagens - "será esta a Maria da Fonte?” - indica uma compreensão da mentalidade de certa parcela da população, muito acostumada ao regime, que ainda acreditava na necessidade de um líder que a comandasse. Cada cena da peça é uma etapa na desmontagem da ideia de líder, de herói. Cumpre lembrar queé depois das argumentações do Falso Cego sobre a questão do herói que se decide por Maria Angelina ser a Maria da Fonte porque, nesse ponto da peça, não importa mais quem seja a líder; afinal, já se transmitiu a mensagem ou o ensinamento de que é "infeliz a terra que precisa de heróis".

A apoteose grotesca de Cardoso Pires, no final da peça, é uma sátira ao ritual dos cortejos e às festividades cívicas comemorativas patrocinadas pelo regime de Salazar ou por qualquer outro regime totalitário. O sentido da comemoração nesses regimes liga-se à visão da história criada por seus ditadores. É verdade que Salazar, o real chefe do Estado, evitava participar de tais eventos, mas não deixava de promovê-los por todos os cantos do país, mesmo porque era por meio deles que se aplicava e se expandia a propaganda de seu governo e, ao mesmo tempo, compensava-se a realidade social em decadência: "O poder da comemoração é justamente o de criar o acontecimento, aproveitando a carga simbólica de um facto anterior. Serve assim para consagrar o vazio de sentido deixado pela história, recheando-o de todos os artifícios de uma reinterpretação solene" (idem, p.68).

Eé solenemente que entra em cena, na apoteose grotesca de $O$ render dos heróis, o andor de Costa Cabral, outro ditador da história. Esse cortejo solene é criticado veementemente sem que se diga uma palavra sequer. $\mathrm{O}$ visual fala por si: o ditador vestido de bode, talheres em lugar de medalhas no peito dos pares do reino, panelas no lugar de chapéus nas 
cabeças dos barões; o quadro é, de fato, grotesco no sentido etimológico do termo. A cena, literalmente muda, grita para os espectadores para que não apenas vejam, mas analisem criticamente a real situação. Se a ditadura salazarista utilizava as comemorações e festividades como meios para convencer a população da grandeza do passado do país, que a propaganda do regime ditatorial propunha exaltar, a cena final de Cardoso Pires se vale dos mesmos meios, mas para alcançar o efeito inverso, qual seja, o de despertar a consciência.

É possível traçar um paralelo entre as duas apoteoses: a pretendida pela Exposição do Mundo Português e a da peça de Cardoso Pires. Em ambas, o que se pretende é criar a "consciência nacional" por meio da relação passadopresente. No entanto, se a primeira, ocorrida vinte anos antes da publicação da peça e tendo marcado a história recente do país, pretendia que "os visitantes saíssem mais exaltados que propriamente instruídos” (idem), a segunda tem por objetivo impedir que os espectadores saiam emocionalmente satisfeitos, mas "socialmente insatisfeitos", como escreveu Mario Vilaça, em 1966, quando procurava definir o espectador do teatro épico. Cardoso Pires, então, inverte propositadamente a referência do seu leitor/espectador português acostumado, por mais de quarenta anos, a ver diante dos olhos tantas festividades e comemorações. O conhecido torna-se estranho e, por isso, distanciado. Nem é preciso repetir que a lição de Brecht se realiza de forma original justamente aí, nessa apoteose recriada por Cardoso Pires.

De fato, tornar estranho o conhecido é a mais clara característica do engenho e da arte de Cardoso Pires nessa que é sua primeira e penúltima criação dramática. Ele trabalha com a aproximação do referencial e dele se distancia deliberadamente para que se processe o despertar da crítica. Dessa forma, primeiro seleciona o material: fato histórico 
conhecido ocorrido no campo, poesia de Afonso Duarte (falecido em 1958, cujos poemas versam sobre a vida no campo, o folclore, as aldeias etc.) e caricaturas das personalidades do episódio histórico, publicadas nos jornais da época; em seguida, rearranja tudo fazendo uma releitura do fato histórico em que desconstrói a figura heroica da que seria a líder da revolta popular, "des-heroicizandoa"; insere os poemas para interromper a continuidade da narrativa, tornando-os elementos narrativos, e termina por transpor para o palco as caricaturas das figuras políticas da época de forma ridícula, grotesca. Assim, comunica-se com o público de seu tempo, tomando o passado como pretexto, inserindo-o no contexto político contemporâneo, em um momento em que a exaltação do passado e a valorização do campo e das tradições populares e folclóricas eram preconizadas pela ditadura. Parece que o nosso dramaturgo "por acidente" - mas "acidente feliz", como disse Luiz Francisco Rebello - criou uma forma, um sistema, de elaboração da peça que, à primeira vista, parece comungar com o que pretendia o regime. Será, talvez, por isso que o texto e a encenação tenham, em um primeiro momento, conseguido passar pela censura? Tendo em vista que o nível intelectual dos censores não era lá muito elevado - como atestam historiadores, e o próprio Cardoso Pires, que analisaram os processos da censura em Portugal -, não é questão para se descartar.

$\mathrm{Na}$ imutável e longeva ordem do mundo - do mundo português, pelo menos -idealizada por Salazar, não caberia jamais uma arte que viesse a abalar as estruturas. Por isso, Brecht foi proibido de ser representado em Portugal, já que a obra do dramaturgo alemão, nas palavras de Barthes (1984, p.194, grifo do autor), "visa elaborar uma prática do abalo", e o abalo, continua o crítico francês, "é uma re-produção, não uma imitação, mas uma produção defasada, deslocada: que faz barulho". 
Essa prática brechtiana do abalo começa a ser desenvolvida no teatro português a partir de Cardoso Pires, abrindo caminho para que outros dramaturgos seguissem a mesma linha. É o caso de Luís de Sttau Monteiro com Felizmente há luar!, que também fala diretamente para o público de seu tempo.

O que mais nos chama a atenção na peça de Sttau Monteiro é o fato de a personalidade ou personagem "principal" não aparecer jamais em cena. A imagem de Gomes Freire é referida e reverenciada pelo grupo que o defende, ou seja, o povo, e, por outro lado, desprezada pelos governadores do reino, que o condenam.

A ausência física de Gomes Freire na peça de Sttau Monteiro fortalece a figura do general na perspectiva do espectador. O público assiste ao que se passa nos bastidores do Poder, é-lhe apresentada didaticamente a formação dos mecanismos de repressão. O general, então, fica em vias de se tornar um mártir ou um herói, mas também Sttau Monteiro - tal como fez Cardoso Pires com a sua Maria da Fontenão permite que isso aconteça porque ausenta a personagem das cenas. Gomes Freire "nunca aparece, mas está sempre presente". E o povo, que o reverencia, como fica diante dessa ausência, que no contexto da fábula é representada pela prisão do general? A personagem Manuel, "o mais consciente dos populares", tem a explicação: "Mas o general está preso em S. Julião da Barra e nós... estamos presos à nossa miséria, ao nosso medo, à nossa ignorância...". No final da peça-de "clima apoteoticamente trágico" (Barata, 1991)-, Matilde pede ao povo que olhe bem para o clarão da fogueira, é ele a luz redentora que desperta o juízo dos homens para que eles se conscientizem de sua condição de miséria e medo frente à força repressiva do Poder. Diante dessa constatação parece ficar no ar que algo precisa ser feito.

Durante todo o tempo de permanência da ditadura salazarista, era de se notar que o chefe do Conselho pouco 
se expunha, pouco aparecia até mesmo nas festividades e comemorações promovidas pelo regime do qual era o mentor maior. Essa ausência, na verdade, fortalecia ainda mais a imagem de Salazar como homem que se devotava ao trabalho, não tinha vida social, era celibatário, solitário, não participava da vida pública. Ao "suprimir" a figura física do general Gomes Freire da peça, Sttau Monteiro aproxima seu texto do mundo conhecido do espectador, mas logo o torna estranho porque a imagem que vai se formando de Gomes Freire ao longo da peça não é exatamente a do conspirador preterido pelos governadores do reino. Inverte-se a chave em dois sentidos. Primeiro que quem conspira, na verdade, são os governadores do reino - o Poder, pois, e não o antipoder, para usar a designação de Oliveira Barata. Segundo Gomes Freire "não é um santo, é um homem como todos nós" - diz o Antigo Soldado - e tampouco um herói; é apenas um "amigo do povo" e, além disso, ele nem aparece em cena. Gomes Freire é personagem simbólica, na peça e na história, pelo menos na leitura de Sttau Monteiro. Mais que a injustiça que ele sofre, o que é aí enfatizado é a articulação ardilosa do Poder, que se organiza para eliminar qualquer coisa que possa abalar suas estruturas.

Os diálogos dos governadores do reino refletem o fictício mundo português desejado pelo regime: "Temos uma missão a cumprir, uma missão sagrada e penosa: a de conservar no jardim do Senhor este pequeno canteiro português. Enquanto a Europa se desfaz, o nosso povo tem de continuar a ver no céu a Cruz de Ourique"; "esta terra [Portugal] de gente pobre, mas feliz” (Sttau Monteiro, 1980, p.43), diz o Principal Sousa. Os valores exaltados por Salazar são claramente referidos na peça, e por meio deles se define a figura do ditador ou o que ele representa.

Se a peça alegoricamente reflete a imagem de Salazar nos diálogos dos governadores do reino, ela, a imagem, obviamente não é espelhada pela figura simbólica do general, mas 
especificamente pela de D. Miguel Pereira Forjaz: "Sonho com um Portugal próspero e feliz, com um povo simples, bom e confiante, que viva lavrando a terra, com os olhos postos no Senhor" (idem, p.76). As falas de D. Miguel, de fato, conferem-lhe um perfil muito similar ao de Salazar - e aqui apresentamos mais um último exemplo: "Sou um homem de gabinete. Não tenho as qualidades necessárias para falar ao povo... Repugna-me a acção, estaria politicamenteliquidado se tivesse que discutir as minhas ordens" (idem, p.78). A imagem do ditador, enfim, se faz presente alegoricamente, na peça, ao lado dos verdadeiros conspiradores.

A transposição alegórica dos fatos históricos, pretendida por seus autores nas duas peças que aqui estudamos, e a proposta, que o teatro português já vinha desenvolvendo, de concomitantemente pensar o teatro e fazer pensar o público, coadunam com a estética teatral proposta por Brecht. Vemos nas duas peças um grande cuidado com a construção formal do texto, que naquele dado momento era mais para ser lido que para ser encenado, independentemente dos esforços de seus autores, da crítica teatral e dos encenadores. Cardoso Pires e Sttau Monteiro, no entanto, não ficaram presos às técnicas brechtianas, não limitaram sua carpintaria teatral ao que muitos outros viram simplesmente como um modelo formal baseado em projeções, cartazes e indicações para uma personagem falar diretamente ao público, como se esses recursos bastassem para tornar épica a peça que escreviam. A simples utilização da técnica não significa tornar a peça épica no sentido brechtiano, como aponta Mario Vilaça (1966); é preciso vitalidade poética, independentemente da estética.

Roberto Schwarz (1999) declara que o ensinamento que se busca no anti-ilusionismo brechtiano "é mais da ordem da pergunta que da resposta"; diríamos que da ordem da pergunta indireta, isto é, daquela que paira no ar, pois é essa que faz refletir (a pergunta direta, por sua objetividade, 
parece ter já uma resposta "certa" ou esperada). A pergunta que se coloca nas peças dos nossos autores extrapola o enredo das peças de final conhecido - seja por causa do episódio histórico, seja porque o desfecho está implícito no título da obra -; a pergunta está, no fundo, na fábula que expõe as contradições e incoerências humanas; daí advém o questionamento, a dúvida, que estimula a reflexão e, por consequência, define o posicionamento crítico.

As peças de Cardoso Pires e Sttau Monteiro conversam com o seu tempo. Dirigem-se ao público - leitor/espectador - a fim de propor mudanças no teatro e nos rumos da história. 


\section{REFERÊNCIAS BIBLIOGRÁFICAS}

ARENDT, H. Bertolt Brecht (1898-1956). In: Homens em tempos sombrios. Tradução de Denise Bottmann. São Paulo: Cia. das Letras, 1987. p.177-213.

ARNAUT, A. P. S. Post-modernismo no romance português contemporâneo: fios de Ariadne - máscaras de Proteu. Coimbra: Almedina, 2002.

BARATA, J. O. História do teatro português. Lisboa: Universidade Aberta, 1991.

BARTHES, R. O rumor da língua. Tradução de António Gonçalves. Lisboa: Edições 70, 1984.

Diderot, Brecht, Eisenstein. In: Oóbvio e o obtuso. Tradução de Lea Novaes. Rio de Janeiro: Nova fronteira, 1990. p.85-96.

Crítica e verdade. Tradução de Leyla PerroneMoisés. São Paulo: Perspectiva, 1999.

BENJAMIN, W. Tentativas sobre Brecht. Tradução de Jesus Aguirre. Madrid: Taurus, 1987.

BENTLEY, E. A experiência viva do teatro. Tradução de Álvaro Cabral. Rio de Janeiro: Zahar Editores, 1967.

O dramaturgo como pensador: um estudo da dramaturgia nos tempos modernos. Tradução de Ana Zelma Campos. Rio de Janeiro: Civilização Brasileira, 1991. 
BOLLE, W. A linguagem gestual no teatro de Bertolt Brecht. Projekt - Revista da Associação Paulista de Professores de Alemão, São Paulo, n.1, p.26-30, nov. 1986.

BORNHEIM, G. Brecht: a estética do teatro. Rio de Janeiro: Graal, 1992.

BRAGA, T. Gomes Freire. Porto: Lello \& Irmão, 1907.

BRANDÃO, R. Vida e morte de Gomes Freire. Lisboa: Alfa, 1990.

BRECHT, B. Teatro dialético: ensaios. Seleção e introdução de Luiz Carlos Maciel. Rio de Janeiro: Civilização Brasileira, 1967.

Vida de Galileu. Tradução de Roberto Schwarz. São Paulo: Paz e Terra, 1991. A alma boa de Setsuan. Tradução de Geir Campos e Antônio Bulhões. São Paulo: Paz e Terra, 1992.

Poemas: 1913-1956. Tradução de Paulo César de Souza. São Paulo: Ed. 34, 2000.

. Diário de trabalho: 1938-1941. Tradução de Reinaldo Guarany e José Lourenio de Melo. São Paulo: Rocco, 2002, v.1.

Diário de trabalho: 1941-1947. Tradução de Reinaldo Guarany e José Lourenio de Melo. São Paulo: Rocco, 2005, v.2.

Estudos sobre teatro. Tradução de Fiama Pais Brandão. Rio de Janeiro: Nova Fronteira, 2005.

CARDOSO PIRES, J. O render dos heróis. Lisboa: Moraes Editores, 1970.

E agora, José? Lisboa: Moraes Editores, 1977.

O delfim. Rio de Janeiro: Civilização Brasileira, 1983.

CARLSON, M. Teorias do teatro: estudo histórico-crítico dos gregos à atualidade. Tradução de Gilson César Cardoso de Souza. São Paulo: Ed. da Unesp, 1997.

CARVALHO, S. (Org.). Introdução ao teatro dialético: experimentos da Companhia do Latão. São Paulo: Expressão Popular, 2009.

CORREIA, R. "Estranhamento": venturas e desventuras de um conceito estético-teórico. Cadernos de Literatura, Coimbra, n.20, p.15-25, 1985. 
COSTA, H. O render dos heróis pelo Teatro Moderno de Lisboa. Vértice - Revista de Arte e Cultura, Coimbra, n.258, p.228-232, 1965.

CRUZ, D. I. História do teatro português. Lisboa: Editorial Verbo, 2001.

DELILLE, M. M. G. Bertolt Brecht em Portugal antes do 25 de abril de 1974: um capítulo da história da resistência salazarista. Dedalus - Revista Portuguesa de Literatura Comparada, Lisboa, n.1, p.63-88, dez. 1991a.

. (Coord. e pref.) Do pobre B. B. em Portugal: aspectos da recepção de Bertolt Brecht antes e depois do 25 de abril de 1974. Aveiro: Estante, 1991b.

DESUCHÉ, J. La técnica teatral de Bertolt Brecht. Barcelona: Oikos-tau, 1966.

JAMESON, F. O método Brecht. Tradução de Maria Sílvia Betti. Petrópolis: Vozes, 1999.

KOUDELA, I. D. Brecht na pós-modernidade. São Paulo: Perspectiva, 2001.

MAGALDI, S. O texto no teatro. São Paulo: Perspectiva, 2001.

MENDONÇA, F. Para o estudo do teatro em Portugal: 19461966. Assis: Faculdade de Filosofia, Ciências e Letras de Assis, 1971.

OLIVEIRA, F. M. O destino da mimese e a voz do palco: o teatro português moderno. Braga: Angelus Novus, 1997.

OLIVEIRA MARQUES, A. H. de. História de Portugal: das revoluções liberais aos nossos dias. Lisboa: Editorial Presença, 1998. v.III.

OLIVEIRA MARTINS, J. P. de. Portugal contemporâneo. Lisboa: Livro de Antonio Maria Pereira, 1895. Disponível em: http://www.purl.pt/158. Acesso em: 15 maio 2009.

PAVIS, P. Dicionário de teatro. Tradução de J. Guinsburg e Maria Lucia Pereira. São Paulo: Perspectiva, 2007.

PORTELA, A. Cardoso Pires por Cardoso Pires. Lisboa: Publicações Dom Quixote, 1991.

QUADROS, A. Teatro. In: Crítica e verdade: introdução à actual literatura portuguesa. Lisboa: Clássica Editora, 1964. p.199-266. 
REBELLO, L. F. O jogo dos homens: ensaios, crônicas e críticas de teatro. Lisboa: Ática, 1971.

História do teatro português. Lisboa: EuropaAmérica, 1972.

Combate por um teatro de combate. Lisboa: Seara Nova, 1977.

Cem anos de teatro português (1880 - 1980). Porto: Brasília Editora, 1984.

Fragmentos de uma dramaturgia. Lisboa: Imprensa Nacional, Casa da Moeda, 1994.

Breve história do teatro português. Lisboa: EuropaAmérica, 2000.

REDONDO JÚNIOR, J. Pano de ferro: crítica, polêmica, ensaios de crítica teatral. Lisboa: Século, 1955.

Panorama do teatro moderno. Lisboa: Arcádia, 1961.

RIBEIRO, A. S. Ainda acerca do "Estranhamento": novas desventuras de um conceito estético-teórico. Cadernos de Literatura, Coimbra, n.22, p.13-25, 1985.

RODRIGUES, G. A. Breve história da censura literária em Portugal. Lisboa: Instituto de Cultura e Língua Portuguesa, 1980.

RODRIGUES, U. T. Noites de teatro. Lisboa: Ática, 1961. v.1. RODRIGUES, W. Técnicas do distanciamento no teatroépico de Bertolt Brecht. Revista de Letras, Assis, v.13, p.193-209, 1970-1971.

ROSENFELD, A. O mito e o herói no moderno teatro brasileiro. São Paulo: Perspectiva, 1996.

O teatro épico. São Paulo: Perspectiva, 2006.

ROUBINE, J.-J. A linguagem da encenação teatral. Tradução de Yan Michalski. Rio de Janeiro: Jorge Zahar, 1998.

Introdução às grandes teorias do teatro. Tradução de André Telles. Rio de Janeiro: Jorge Zahar, 2003.

SANTOS, G. dos. O espetáculo desvirtuado: o teatro português sob o reinado de Salazar (1933-1968). Lisboa: Editorial Caminho, 2004.

SARAIVA, J. H. História concisa de Portugal. Lisboa: EuropaAmérica, 1988.

SÉRIO, M. Sobre Brecht. Lisboa: Ulmeiro, 1976. 
SCHWARZ, R. Altos e baixos da atualidade de Brecht. In: Sequências brasileiras. São Paulo: Cia. das Letras, 1999. p.113-48.

SIMÕES, J. G. Crítica VI: o teatro contemporâneo(1942-1982). Lisboa: Imprensa Nacional: Casa da Moeda, 2004.

STTAU MONTEIRO, L. de. Felizmente há luar! Lisboa: Ática, 1980.

SZONDI, P. Teoria do drama moderno. Tradução de Luiz Sérgio Repa. São Paulo: Cosac \& Naify, 2001.

TOUCHARD, P.-A. O teatro e a angústia dos homens. Tradução de Pedro Paulo de Sena Madureira e Bruno Palma. São Paulo: Duas Cidades, 1970.

VILAÇA, M. Felizmente há luar!, de Luís de Sttau Monteiro. Vértice - Revista de Arte e Cultura, Coimbra, n.221, p.136-8, fev. 1962.

Comentários a uma tradução de Brecht. Vértice Revista de Arte e Cultura, Coimbra, n.232-233, p.90-3, jan./fev. 1963a.

Panorama do teatro português contemporâneo. Vértice - Revista de Arte e Cultura, Coimbra, n.234-236, p.205-20, mar./maio 1963b.

. Do teatroépico. Vértice - Revista de Arte e Cultura, Coimbra, n.271-272, p.261-81, abr./maio 1966.

WERNECK, M. H. A história do outro lado da cortina: uma leitura da peça $O$ render dos heróis, de José Cardoso Pires. Semear - Revista da Cátedra Padre António Vieira de Estudos Portugueses, Rio de Janeiro, n.11, p.219-41, 2005.

WILLETT, J. O teatro de Brecht. Tradução de Álvaro Cabral.

Rio de Janeiro: Zahar, 1967.

WILLIAMS, R. Uma rejeição à tragédia: Brecht. In:

Tragédia moderna. Tradução de Betina Bischof. São Paulo: Cosac \& Naify, 2002. p.247-64.

\section{Bibliografia complementar}

ARISTÓTELES. Poética. Tradução de Eudoro de Souza. In. Os Pensadores. São Paulo: abril, 1973. p.443-71. 
BALL, D. Para frente para trás: um guia para leitura de peças teatrais. São Paulo: Perspectiva, 1999.

BARRENTO, J. (Org.) Realismo, materialismo, utopia: uma polêmica (1935-1940). Lisboa: Moraes Editores, 1978.

BARRETO, C. (Org.) Estrada Larga. Porto: Tip. Bloco Gráfico, 1959.

BERTHOLD, M. História mundial do teatro. Tradução de Maria Paula Zurawski, J. Guinsburg, Sérgio Coelho e Clóvis Garcia. São Paulo: Perspectiva, 2004.

CARY, L.; RAMOS, J. J. M. (Orgs.) Teatro e vanguarda. Lisboa: Editorial Presença, 1970.

COSTA, I. C. A hora do teatro épico no Brasil. Rio de Janeiro: Paz e Terra, 1996.

ESSLIN, M. Brecht: dos males o menor. Rio de Janeiro: Zahar, 1979.

FARIA, J. R. O teatro na estante. São Paulo: Ateliê Editorial, 1998.

GARCIA, J. M. História de Portugal: uma visão global. Lisboa: Editorial Presença, 1989.

GARCIA, S. Teatro da militância. São Paulo: Perspectiva/ Edusp, 1990.

GIRARD, G.; OUELLET, R.; RIGAULT, C. O universo do teatro. Tradução de Maria Helena Arinto. Coimbra: Almedina, 1980.

GUINSBURG, J. Da cena em cena. São Paulo: Perspectiva, 2001.

HANSEN, J. A. Alegoria: construção e interpretação da metáfora. São Paulo: Hedra; Campinas: Ed. da Unicamp, 2006.

MACHADO, C. E. J. Um capítulo da história da modernidade estética: debate sobre o expressionismo. São Paulo: Ed. da Unesp, 1998.

MASSAUD, M. A literatura portuguesa. São Paulo: Cultrix, 1991.

MATEUS, J. A. O. de A. Do teatro e outras escritas. [Lisboa]: Quimera, 2002.

MEDINA, J. (Org.) História de Portugal Contemporâneo - político e institucional. Lisboa: Universidade Aberta, 1994. 
PASTA JUNIOR, J. A. Trabalho de Brecht: breve introdução ao estudo de uma classicidade. São Paulo: Ática, 1986.

PEIXOTO, F. Brecht: uma introdução ao teatro dialético. Rio de Janeiro: Paz e Terra, 1981.

Portugal: o espaço do possível? In: Teatro em movimento. São Paulo: Hucitec, 1989. p.104-5.

Brecht: vida e obra. São Paulo: Paz e Terra, 1991.

PETROV, P. O realismo na ficção de José Cardoso Pires e Rubem Fonseca. Miraflores: Difel 82, 2000.

PICCHIO, L. S. História do teatro português. Lisboa: Portugália, 1969.

PORTO, C.; MENEZES, S. T. 10 anos de teatro e cinema em Portugal: 1974-1984. Lisboa: Editorial Caminho, 1985.

POSADA, F. Lukács, Brecht e a situação atual do realismo socialista. Tradução de A. Veiga Fialho. Rio de Janeiro: Civilização Brasileira, 1970.

SARTINGEN, K. Brecht no teatro brasileiro. Tradução de José Pedro Antunes. São Paulo: Hucitec, 1998.

SECCO, L. A Revolução dos Cravos. São Paulo: Alameda, 2004.

TENGARRINHA, J. (Org.) História de Portugal. Bauru: Edusc; São Paulo: Ed. da Unesp; Portugal: Instituto Camões, 2001.

TENSCHERT, J. A máscara no Beliner Ensemble. VérticeRevista de Arte e Cultura, Coimbra, n.226-227, p.411-4, jul./ago. 1962.

TORRES, A. P. Sociologia e significado no mundo romanesco de José Cardoso Pires. In: Romance: o mundo em equação. Lisboa, Portugália, 1967.

UBERSFELD, A. Para ler o teatro. Tradução de José Simões. São Paulo: Perspectiva, 2005.

WAGNER, F. Teoria e técnica teatral. Coimbra: Almedina, 1978. 
SOBRE O LIVRO

Formato: $12 \times 21 \mathrm{~cm}$

Mancha: $20 \times 40,4$ paicas

Tipologia: Horley Old Style 10,5/14

1ª edição: 2010

\section{EQUIPE DE REALIZAÇÃO}

Coordenação Geral

Marcos Keith Takahashi 